\title{
Effect of plant traits on host selection and performance of rape stem weevil (Ceutorhynchus napi Gyll.) (Col.: Curculionidae) on resynthesized lines and cultivars of oilseed rape (Brassica napus L.)
}

\author{
Dissertation \\ zur Erlangung des Doktorgrades \\ der Fakultät für Agrarwissenschaften \\ der Georg-August Universität Göttingen
}

vorgelegt von

Heike Lena Schäfer-Kösterke

geboren in Schorndorf

Göttingen, Juli 2014 


\section{7}

1. Referent:

Prof. Dr. Stefan Vidal

2. Korreferent:

Prof. Dr. Heiko Becker

Tag der mündlichen Prüfung: 24. Juli 2014 


\section{Table of contents}

$\begin{array}{lll}\text { Summary } & 1\end{array}$

Chapter I - General introduction 3

Oilseed rape 4

Insect pests of oilseed rape crops 4

Rape stem weevil $\quad 5$

Interaction between stem-mining weevils C. napi and C. pallidactylus 8

$\begin{array}{ll}\text { Pest management strategies } & 8\end{array}$

Host plant resistance $\quad 9$

$\begin{array}{ll}\text { Methods of identification of host plant resistance } & 11\end{array}$

$\begin{array}{ll}\text { Host selection by herbivorous insects } & 12\end{array}$

$\begin{array}{ll}\text { Objectives of the study } & 18\end{array}$

$\begin{array}{ll}\text { References } & 19\end{array}$

Chapter II - Effect of various genotypes of oilseed rape (Brassica napus L.) on larval infestation and performance of rape stem weevil (Ceutorhynchus napi Gyll.) 33

$\begin{array}{ll}\text { Abstract } & 34\end{array}$

Introduction $\quad 34$

Material and Methods $\quad 36$

Data analysis $\quad 38$

Results 40

$\begin{array}{ll}\text { Discussion } & 47\end{array}$

Acknowledgements $\quad 51$

References

Chapter III - Evaluation of resynthesized lines and cultivars of oilseed rape (Brassica napus L.) for oviposition preference and larval performance of rape stem weevil $\begin{array}{ll}\text { (Ceutorhynchus napi Gyll.) } & 57\end{array}$

Abstract $\quad 58$

$\begin{array}{ll}\text { Introduction } & 59\end{array}$

$\begin{array}{ll}\text { Material and Methods } & 61\end{array}$

Data analysis $\quad 63$

$\begin{array}{ll}\text { Results } & 65\end{array}$

$\begin{array}{ll}\text { Discussion } & 77\end{array}$

$\begin{array}{ll}\text { Acknowledgements } & 81\end{array}$

$\begin{array}{ll}\text { References } & 82\end{array}$ 
Chapter IV - Screening of oilseed rape (Brassica napus $L_{\text {.) }}$ genotypes for susceptibility to infestation by rape stem weevil (Ceutorhynchus napi Gyll.) and cabbage stem weevil (Ceutorhynchus pallidactylus (Marsh.))

Abstract

Introduction

Material and Methods

Data analysis

Results

Discussion

Acknowledgements

References

Chapter V - General discussion

Responses of C. napi and C. pallidactylus to plant genotypes 126

Plant responses to C. napi infestation 129

Conclusion

References

Appendix 


\section{Summary}

Oilseed rape is attacked by a wide range of insect pests during its growing season across Europe. Infestation by rape stem weevil (Ceutorhynchus napi Gyll.) and cabbage stem weevil (Ceutorhynchus pallidactylus (Marsh.)) can cause major economic damage. At present, the control of these insect pests is strongly based on synthetic insecticides. Resistant cultivars are an important element in integrated pest management and an important breeding trait in oilseed rape. No resistance to infestation by $C$. napi has been found to date within the gene pool of Brassica napus L.. Resynthesized lines of oilseed rape can be developed by crossing the two progenitor species (Brassica oleracea L. X Brassica rapa L.). Because of their broad genetic variability, resynthesized lines of oilseed rape can provide potential sources of resistance to diseases and pests.

The major objectives of the present study were to determine the susceptibility of 30 genetically diverse genotypes of $B$. napus for infestation by the specialist stem weevil $C$. napi. In addition, open field experiments were conducted in two years to assess the susceptibility of all 30 genotypes for infestation by C. napi and C. pallidactylus larvae. In open field and laboratory experiments, the host plant acceptance of eight selected genotypes was assessed by evaluating the number of eggs deposited by $C$. napi into stems. To determine differences in plant responses to oviposition by $C$. napi between the selected genotypes, the severity of pith tissue degeneration per stem was assessed. In the semi-field experiment, the susceptibility of twelve selected genotypes for infestation by $C$. napi larvae was evaluated. Differences in the larval performance of $C$. napi between selected genotypes were assessed by determining the instar index and the dry body mass of larvae. To identify plant resistance mechanisms affecting plant infestation by $C$. napi, both plant metabolic and morphological plant traits were evaluated. Stems and leaves of genotypes of oilseed rape were analyzed for glucosinolates and other plant metabolites such as carbon and nitrogen. Additionally, morphological plant traits such as the stem base diameters and stem lengths of various genotypes and sampling dates were evaluated during the natural infestation period of C. napi. Quantitative differences between genotypes were evaluated by measuring plant stem biomasses. These morphological and plant metabolic traits were related to the number of eggs laid, larval infestation and larval performance of C. napi.

The results obtained in open field and laboratory experiments indicated considerable variation between the number of eggs deposited by $C$. napi into stems of different resynthesized lines, cultivars and lines of oilseed rape. The number of eggs in resynthesized lines, particularly in lines S30 was on a very low level, while the resynthesized line H30 and 
the cultivar Sollux (open field) and the cultivar Oase (laboratory) showed a high number of eggs. The low numbers of eggs indicated antixenosis resistance in S30 to C. napi. In the open field, the degree of pith tissue degeneration in stems differed significantly between genotypes. In S30, the severity of pith tissue degeneration was significantly lower than in H30. In open field and semi-field experiments, S30 contained a significantly lower number of C. napi larvae compared to other tested genotypes, such as Sollux and the resynthesized line L16. The low number of larvae in S30 may result from a reduced oviposition, while egg or larval mortality, reflected by the ratio between the number of eggs and larvae did not significantly differ between selected genotypes. The larval development time, reflected by the larval instar index, was significantly prolonged in S30 compared to L16 (semi-field) and H30 (open field), thereby indicating antibiosis resistance in S30. In the open field, the number of $C$. pallidactylus larvae did not significantly differ between test genotypes. However, in S30 the infestation by C. pallidactylus larvae was on a low level as well.

Glucosinolates and other metabolites have been shown to affect host acceptance and performance of crucifer-feeding insects. Therefore, in open field and semi-field experiments the glucosinolate content and profile in the stems of genotypes were analyzed in order to determine the effect of glucosinolates on plant infestation by C. napi. In the open field, the number of eggs in stems was positively dependent upon levels of five stem glucosinolates, glucobrassicanapin, glucoalyssin, glucobrassicin, neoglucobrassicin and gluconasturtiin. In semi-field and open field experiments, the number of full-grown larvae in stems was not dependent upon the glucosinolate contents of stems. Additionally, the larval instar index and the larval dry body mass of $3^{\text {rd }}$ larval instar of $C$. napi were not dependent upon the content of stem glucosinolates. In the open field, the nitrogen and carbon content in stems of tested genotypes were not dependent upon the number of eggs, number of larvae and the larval performance of $C$. napi. In the open field, the number of eggs deposited by $C$. napi into stems at the beginning of the oviposition period of $C$. napi was significantly positive dependent upon length of the stems. In contrast, at peak oviposition, the number of eggs was significantly negative dependent upon length of the stems of genotypes. There was no relationship between the number of eggs and the plant biomasses of the tested genotypes.

The oviposition preference and larval performance of $C$. napi on various genotypes has not been studied in detail before. In this study high antixenosis resistance to C. napi in the resynthesized line S30 has been indentified for the first time. Improved knowledge has been gained in resistance mechanisms, which is required for breeding cultivars of oilseed rape with resistance to insect pests. 


\section{CHAPTER I}

General introduction

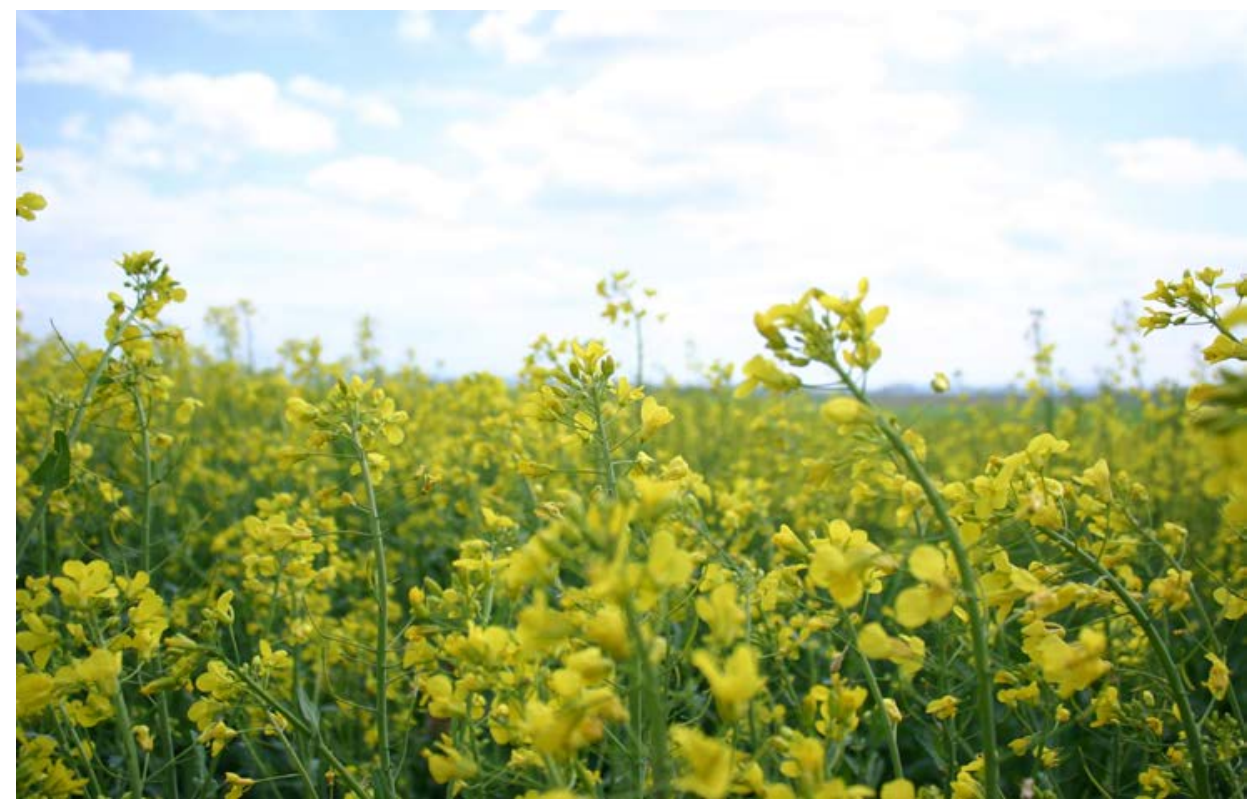




\section{Oilseed rape}

Oilseed rape (Brassica napus L.) has originated from spontaneous hybridization of cabbage (Brassica oleracea L.) and turnip (Brassica rapa L.) (Friedt 2011). Oilseed rape is an important crop in central and northern Europe, especially in the Czech Republic, Denmark, France, Germany, Hungary, Poland, the United Kingdom and Ukraine. Due to its higher yield potential, winter oilseed rape is grown more commonly than spring rape (Kimber and Mc Gregor 1995). In 2013, oilseed rape and turnip rape covered acreage of 1.46 million hectares in Germany. Only France has a higher acreage of 1.61 million grown hectares. In 2013, Germany produced 5.75 million tons of oilseed rape and turnip rape of seed (Eurostat 2014). The European Union is the largest producer of oilseed rape in the world, followed by Canada, China, India, and Australia. Worldwide, oilseed rape is the largest oil crop after soybean and the production of oilseed rape almost doubled during the last 20 years (Mielke 2011). Oil extracted from crushed seed is commonly used for human nutrition and in the production of biodiesel (Alford 2003). Due to its high content of protein and essential amino acids, the seed meal is used in animal nutrition (Bell 1995). Currently, mainly cultivars with very low contents of erucic acid and low contents of glucosinolates in the seeds are grown, known as 'canola quality' or 'double low quality' (Bell 1995; Alford 2003). Due to the low glucosinolate content in the meal, oilseed rape is more suitable for animal fodder (Bell 1995). Oilseed rape oil is suitable for human nutrition because of its very low erucic acid level (Bell 1995; Uppstroem 1995).

\section{Insect pests of oilseed rape crops}

In Europe, oilseed rape is attacked by a wide range of insect pests during its growing season. Economic damage is most often caused by pollen beetle (Meligethes aeneus (F.)), cabbage stem flea beetle (Psylliodes chrysocephala (L.)), rape stem weevil (Ceutorhynchus napi Gyll.), cabbage stem weevil (Ceutorhynchus pallidactylus (Marsh.)), cabbage seed weevil (Ceutorhynchus obstrictus (Marsh.)), and brassica pod midge (Dasineura brassicae (Winn.)) (Alford et al. 2003; Williams 2010). Insect pests of oilseed rape of minor importance are cabbage aphid (Brevicoryne brassicae (L.)), cabbage flea beetles (Phyllotreta spp.), cabbage root fly (Delia radicum (L.)), peach/potato aphid (Myzus persicae (Sulz.)), rape winter stem weevil (Ceutorhynchus picitarsis Gyll.), and turnip sawfly (Athalia rosae) (L.)). In addition, some insect pests, although very occasionally, are reported on oilseed rape crops, such as diamond-back moth (Plutella xylostella (L.)), butterflies (Pieris spp.), and turnip gall weevil (Ceutorhynchus pleurostigma (Marsh.)) (Alford et al. 2003). 


\section{Rape stem weevil}

Rape stem weevil became an important pest of oilseed rape in the South and Southwest of Germany and in Switzerland after the Second World War (Dosse 1951; Schmutterer 1956). Then rape stem weevil gradually spread towards the North of Germany, and today only the Northwest of Schleswig-Holstein and Lower Saxony is not infested by rape stem weevil (Schmutterer 1956; Paul 2003). Host plants of rape stem weevil are oilseed rape, turnip rape, mustard and other brassicaceous plants such as runch and charlock (Paul 2003).

Life cycle: The life cycle of rape stem weevil has been studied by several authors (Fig. 1) (Guenthart 1949; Dosse 1951; Deubert 1952, 1955; Schmutterer 1956; Ballanger 1987a; Le Pape and Bronner 1987; Lerin 1993). Adult weevils migrate from oilseed rape fields of the previous year to the new oilseed rape crops in early spring (March/April). Migration starts at soil temperatures between $5-7^{\circ} \mathrm{C}$ (temperature in $2 \mathrm{~cm}$ depth) and at air temperatures between 9 - $12{ }^{\circ} \mathrm{C}$ (Schmutterer 1956). In addition, sun radiation and wind speed play important roles during the migration to new oilseed rape crops (Schmutterer 1956). After crop colonization, the rape stem weevil undergoes a maturity feeding period of approximately two weeks (Guenthart 1949). Females then begin laying their eggs into the stem pith of oilseed rape, preferably $2 \mathrm{~cm}$ below the buds (Lerin 1993).

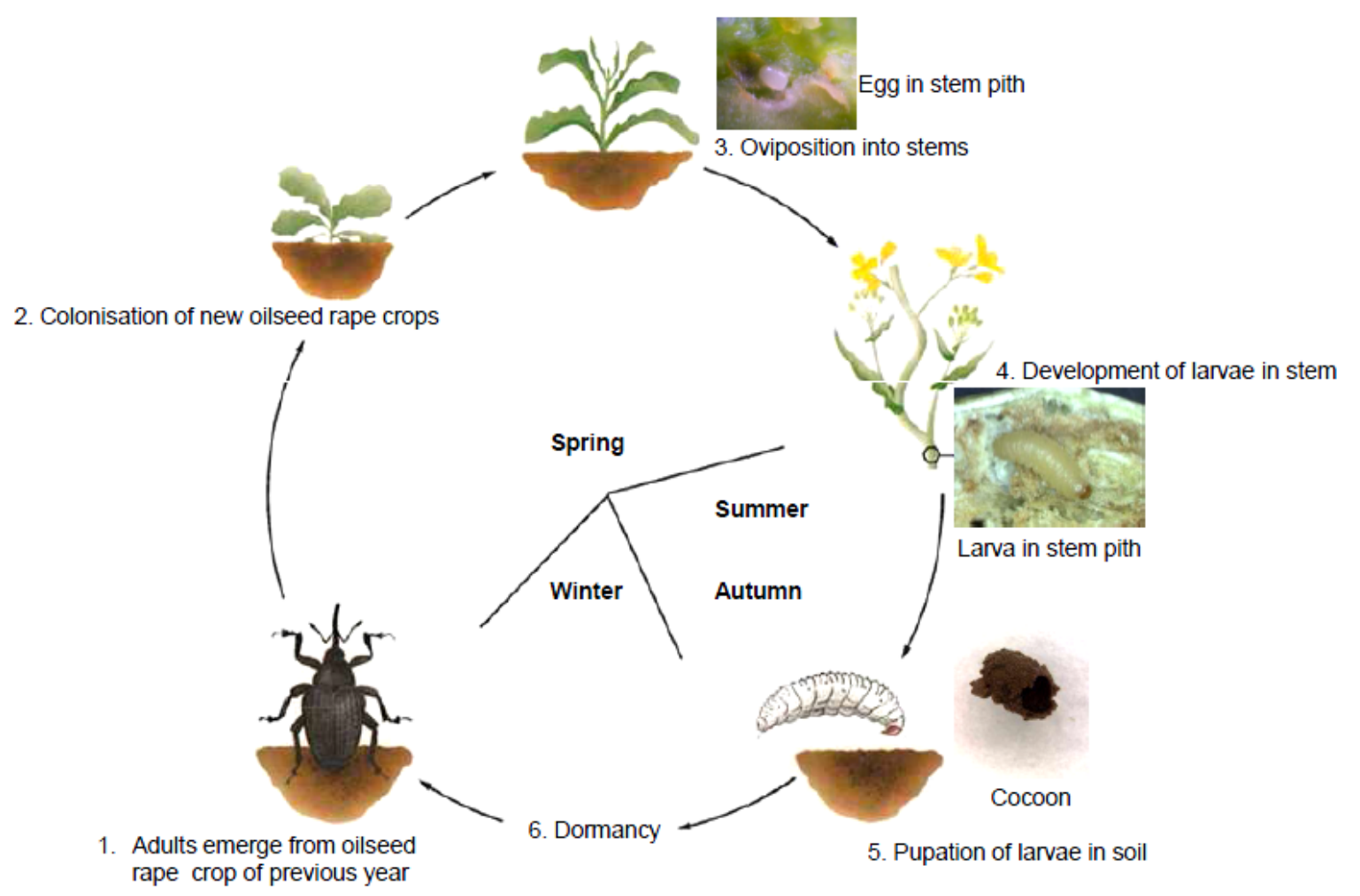

Fig. 1 Life cycle of Ceutorhynchus napi, modified after Paul (2003) 
Females of rape stem weevil feed a small channel slantwise upwards into the rape stem pith into which the egg is introduced (Deubert 1955). A membranous material (exochorion) coats the egg laid into the pith of the stem (Le Pape and Bronner 1987). This material forms a close pouch around the egg; it has been suggested this is to protect the egg from desiccation (Guenthart 1949; Deubert 1955). The larva hatches after 8 - 16 days and feeds within the stem pith for three to five weeks (Dosse 1951). In May/June, the full-grown $3^{\text {rd }}$ instar larva drops to the ground and pupates in an earthen cocoon in soil (Dosse 1951). The pupal stage lasts around three weeks. Adults overwinter within these earthen cocoons (Dosse 1951). Females pass through an obligate, pre-reproductive diapause before they emerge the following spring (Fig. 1).

Damage pattern on rape plants: A few days after oviposition by rape stem weevil, whitish egg-laying punctures are visible on stems of oilseed rape and cabbage species (Dosse 1951; Ballanger 1987b) (Fig. 2).
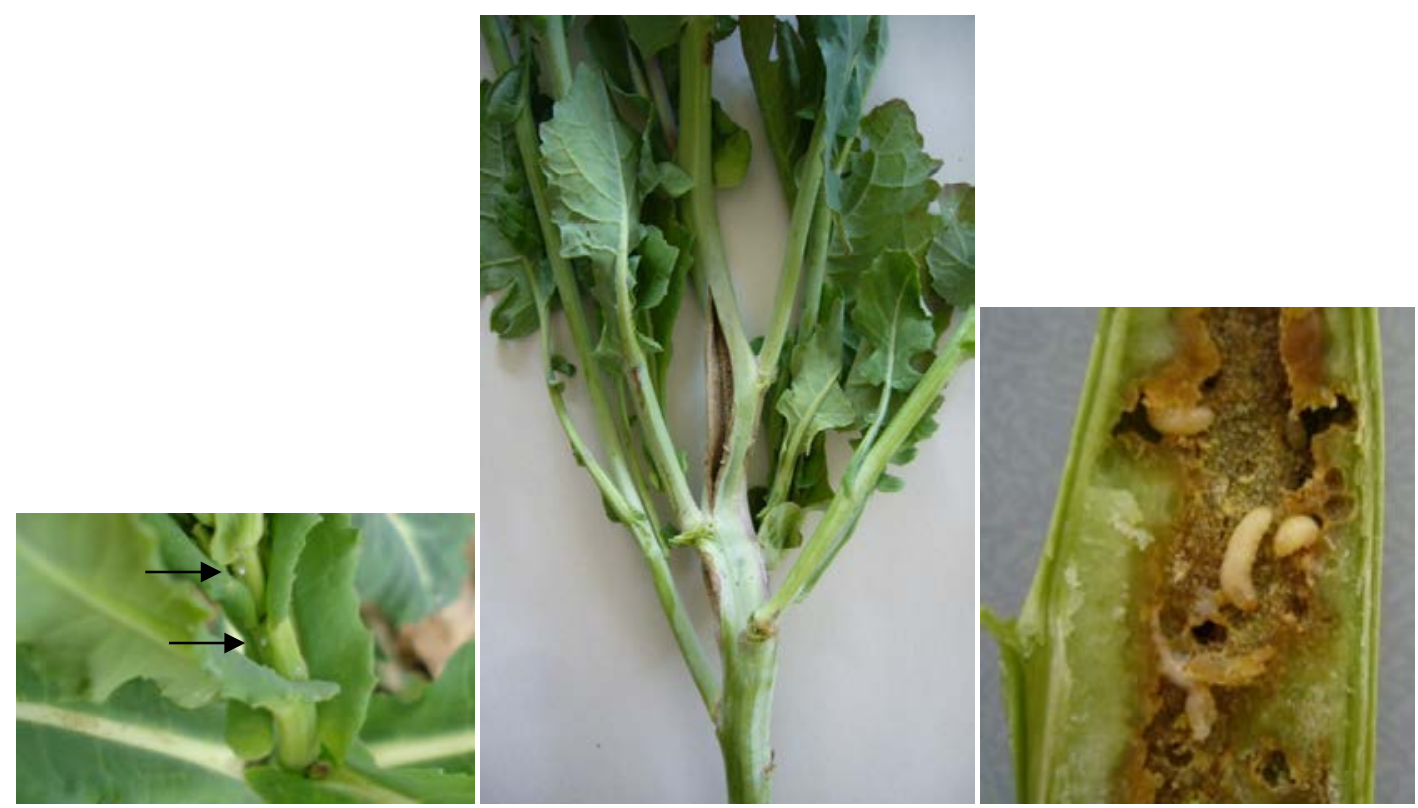

Fig. 2 Left: Whitish egg-laying punctures on stem of oilseed rape (Photo: H. Brandes); Middle: Split and twisted oilseed rape stem; Right: Ceutorhynchus napi larvae and larval feeding tunnels within the stem pith

Oviposition by rape stem weevil takes place during stem elongation growth (Lerin 1993). After egg-laying, the growth rate of stems is the main factor causing splitting of stems (Fig. 2) (Lerin 1993). The extent of splitting is affected by ambient temperatures and is not dependent upon the number of eggs (Lerin 1993). Oilseed rape stems of $>20 \mathrm{~cm}$ length are less susceptible to splitting (Lerin 1993). Egg deposition by females may also result in twisting of stems (S-shaped stems), followed by distortion, considerable disruption to growth and yield losses (Dosse 1951; Buechi 1988; Alford et al. 2003). Disruption to growth is often 
associated with the development of many weak side shoots and delayed flowering (Paul 2003). Larval feeding tunnels occur as a result of larval feeding within the stem pith (Fig. 2) (Dosse 1951).

Gall formation: Plants are able to respond to egg deposition by herbivorous insects (Hilker et al. 2002). Already 24 hours after egg deposition by rape stem weevil into stems, the nuclei of pith tissue cells surrounding the eggs move towards the center of the cells. Cells increase in volume to form a nodule of small, metabolically active cells around the egg (Dosse 1951; Deubert 1955). Cells of the pith surrounding this nodule start to degenerate (Fig. 3). This process is referred to as gall formation (Dosse 1951; Deubert 1955; Hilker et al. 2002). According to Deubert (1955) and Le Pape and Bronner (1987), the gall formation is caused by the egg which induces translocation of water and nutrients from the plant tissue to the nodule. This redistribution of nutrients and water might cause the degeneration of the surrounding cells. However, this suggestion contradicts other studies that found a substance, secreted by females during oviposition, to be responsible for the formation of galls (Guenthart 1949; Deubert 1952).

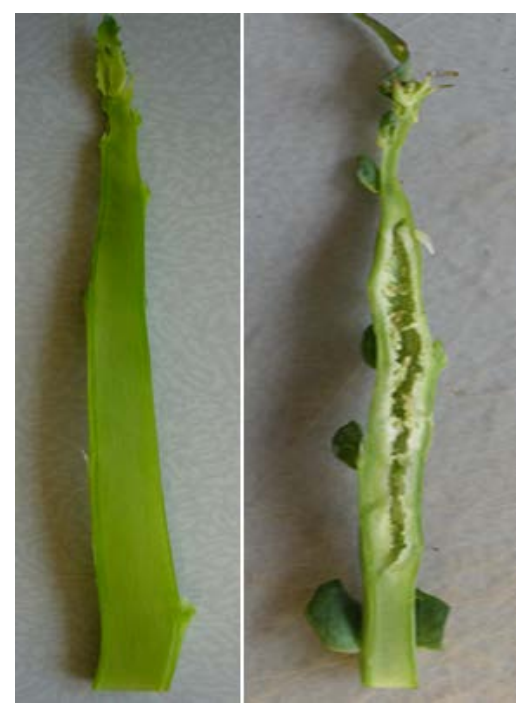

Fig. 3 Left: Non-infested oilseed rape stem with non-degenerated pith tissue; Right: Infested oilseed rape stem section with degenerated pith tissue (Photo: A. Reinhardt)

Damage potential: The pest status of rape stem weevil in oilseed rape has been studied extensively (Guenthart 1949; Schmutterer 1956; Ballanger 1987a; Buechi 1988). Yield losses are depended on the time and level of infestation (Ballanger 1987a; Buechi 1988). The main damage is caused by the egg-deposition of female rape stem weevils, whereas damage by larvae is only of secondary importance (Dosse 1951). The loss of seed yield is affected by the number of eggs deposited by females (Lerin 1993), plant growth stage and the number of 
larvae feeding within stems (Buechi 1988). Well established damage thresholds, based on weevil abundance, are still missing. The abundance of adults on the crop is not indicative of the number of eggs laid by females (Buechi 1988).However, if the threshold of ten adult weevils caught per yellow trap in three days during the colonization period is exceeded, farmers are recommended to apply an insecticide to the oilseed rape crop before the beginning of oviposition (Paul 2003). Plant damage caused by rape stem weevil was found to be lower in vigorous plants obtained by low sowing densities (Nuss 2004). Further, farmers are advised to grow early-flowering cultivars instead of medium- and late-flowering cultivars of oilseed rape (Buechi 1996). Stems of oilseed rape which are longer than $22 \mathrm{~cm}$ are less preferred for oviposition by rape stem weevil (Buechi 1996). Following hibernation, adults migrate to the nearest oilseed rape crop. Therefore, the greater the distance from the oilseed rape field of the previous year to the new oilseed rape crop, the less infestation by rape stem weevil can be expected (Roeder et al. 1980). Tight oilseed rape crop rotations should be avoided (Roeder et al. 1980). During immigration flights, isothiocyanate baited traps have been considered for monitoring rape stem weevil and other insect pests of oilseed rape (Finch 1977; Smart et al. 1993; Kelm and Klukowski 2000).

\section{Interaction between the stem-mining weevils Ceutorhynchus napi and C. pallidactylus}

In Europe, cabbage stem weevil (C. pallidactylus) often occurs together with rape stem weevil on oilseed rape crops (Guenthart 1949). Rape stem weevil and cabbage stem weevil share the same habitat and food resources within the stems of oilseed rape plants. Female cabbage stem weevils lay their egg batches into the petioles of plants. Neonate larvae feed within the petioles before $2^{\text {nd }}$ instar larvae move into the stems to complete their development (Guenthart 1949). Females of cabbage stem weevils preferentially lay their eggs in plants which are already infested by eggs and larvae of rape stem weevil instead of noninfested plants (Dechert and Ulber 2004). Rape stem weevil and cabbage stem weevil avoid interspecific competition, because the larvae of cabbage stem weevil feed preferably in the lower parts of stems (Dechert and Ulber 2004).

\section{Pest management strategies}

At present, the management of insect pests on oilseed rape crops is strongly based on synthetic insecticides (Thieme et al. 2010; Williams 2010). In Germany, most of the registered insecticides against oilseed rape pests belong to the chemical class of pyrethroids 
(BVL 2014). Extensive application of pyrethroids in a sequence within one season for control of main insect pests has resulted in high selection pressure (Thieme et al. 2010). In 2007 to 2012, crops of winter oilseed rape were treated with 2.8 insecticide sprays per year in average in Germany (Freier et al. 2014). Consequently, pollen beetle has developed high levels of resistance to pyrethroids in various European growing regions (Hansen 2003; Derron et al. 2004; Zimmer and Nauen 2011; Zimmer et al. 2014). Resistant pollen beetle populations are found throughout Germany (Heimbach and Mueller 2013; Henning 2013). Insecticides may also have adverse effects on non-target insects (Walters et al. 2003; Thieme et al. 2010; Ulber et al. 2010). In the past considerable effort has been spent to develop alternative pest management strategies. A non-chemical approach is the application of volatile essential oils which may have potential to keep pollen beetles away from their host plants by masking the host plants' volatiles (Mauchline et al. 2005, 2013). The ideal glucosinolate profile of oilseed rape for resistance management against pest infestation was suggested by Bartlet (1999b). The potential to enhance resistance of oilseed rape plants to insect pests by changing the leaf glucosinolate profile was discussed by Mithen (1992). Another non-chemical approach is the enhancement of natural enemies of insect pests (Walters et al. 2003). This can be achieved by reduced tillage after harvest of oilseed rape (Nilsson 2010), which may avoid destruction of larval parasitoids due to deep ploughing (Nitzsche and Ulber 1998; Nilsson 2010). Natural enemies such as parasitoids can also be promoted by the provision of flowering strips (Buechi 2002). Insect pests of oilseed rape can also be controlled by using trap crops (Buechi 1990; Cook et al. 2002; Nilsson 2004; Barari et al. 2005; Cárcamo et al. 2007a; Buechs 2009).

\section{Host plant resistance}

Breeding for host plant resistance is a primary approach for pest control (Painter 1951; Schoonhoven et al. 2005; Singh and Singh 2005). Resistant cultivars can provide an important element for integrated pest management strategies (Gullan and Cranston 2005) and an important breeding trait in oilseed rape (Frauen 2011). Plant resistance can be subdivided in functional (pseudo-resistance) and genetic resistance (Painter 1951). Functional resistance can be classified into three categories: host evasion (host may pass through the most susceptible stage quickly), induced resistance (temporarily increase in resistance as a result of environment) and escape (absence of host plant infestation due to transitory processes like incomplete infestation) (Painter 1951; Schoonhoven et al. 2005). Host evasion is known for females of rape stem weevil which prefer oilseed rape plants shorter than $22 \mathrm{~cm}$ compared to taller plants for oviposition (Buechi 1996). Genetic resistance can be based on the number of 
genes, the biotype, the population, miscellaneous categories or based on the evolutionary concept (Schoonhoven et al. 2005).

Host plant resistance to pest insects was subdivided in the mechanisms non-preference (antixenosis), non-performance (antibiosis) and tolerance (Painter 1951). Antixenosis is the insects' avoidance of plant genotypes during their search for food, oviposition sites, shelter, or for combinations of the three (Painter 1951; Kogan and Ortman 1978; Sarfraz et al. 2006). Antibiosis affects the performance of herbivorous insects such as reduced fecundity, size, weight or longevity and increased mortality of the insect (Smith et al. 1994; Sarfraz et al. 2006). A genotype showing tolerance is able to withstand the damage by herbivorous insects despite a level of infestation that causes damage to a susceptible genotype (Smith et al. 1994). A combination of different defense mechanisms with regard to insect pests has been found in various plant species (Schoonhoven et al. 2005).

Plant features contributing to resistance against herbivores can be plant metabolic compounds and/or morphological plant traits (Sarfraz et al. 2006). Resistance can be constitutive or induced by herbivory (Schoonhoven et al. 2005). Constitutive plant defenses can be based on plant morphology (Way and Murdie 1965; Stoner 1990; Schoonhoven et al. 2005) and/or on secondary metabolites like glucosinolates (Giamoustaris and Mithen 1997; Lambdon et al. 1998). For example, an extensive wound callus tissue formation in petioles of oilseed rape following oviposition by cabbage stem weevil may lead to an increased mortality of egg batches (Nuss 2004).

To improve plant breeding with regard to insect pest resistance traits in oilseed rape a broad genetic variation is required (Snowdon and Friedt 2004; Snowdon 2007; Friedt 2011). However, the genetic variation in oilseed rape is small and targeted breeding for resistance started only less than 70 years ago (Olsson 1960; Song and Osborn 1992). The present breeding material of oilseed rape is derived from a few interspecific hybrid plants (Becker et al. 1995) and no wild forms of oilseed rape have been found (Friedt 2011). Approaches of screening for resistant genotypes and cultivar development in cruciferous plants include resynthesized lines of Brassica species (obtained by interspecific hybridization), identification of QTLs (quantitative trait loci) as genetic markers, plant model-based breeding (Arabidopsis), haploid techniques, protein and/or metabolite studies by 'omics technologies (Snowdon 2007; Duran et al. 2009; Nicolas et al. 2009; Friedt 2011). Resynthesized lines are broadening the genetic variation in oilseed rape (Olsson et al. 1980; Girke et al. 2012). Several studies have been reported the potential of resynthesized lines as sources for the 
improvement of disease resistance (Diederichsen and Sacristan 1996; Rygulla et al. 2007) and pest resistance (Seyis et al. 2001; Eickermann 2011).

Within the Brassicaceae there are some examples of host plant resistance to insects, e.g. to lepidopteran species such as the small white butterfly (Pieris rapae (L.)) (Dickson and Eckenrode 1975; Agrawal and Kurashige 2003) and the diamond-back moth (Dickson et al. 1986; Renwick 2002), to coleopteran species such as cabbage flea beetles (Renwick 2002), mustard leaf beetle (Phaedon cochleariae (F.)) (Uddin et al. 2009), cabbage stem weevil (Eickermann 2011), and cabbage seed weevil (Cárcamo et al. 2007b; Tansey and Dosdall 2011), to hemipteran species such as cabbage aphid (Ellis and Farrell 1995; Messina and Bloxham 2004) and to dipteran species such as cabbage root fly (Tansey and Dosdall 2011).

A future approach with regard to resistance breeding against insects can be the recombinant DNA technology (Alford 2003). Today GM (genetically modified) crops like soybean, cotton, potato, and maize carrying insect resistance traits are grown primarily in North and South America and China (CERA - GM crop database 2014). Insect resistant GM crops primarily depend on the expression of Bacillus thuringiensis $(\mathrm{Bt})$ insecticidal proteins (James 2003). Previous studies demonstrated that a transgenic cabbage genotype expressing $B t$ toxins is resistant to diamond-back moth (Jin et al. 2000; Liu et al. 2008) and transgenic oilseed rape containing a harmful enzyme and a toxic insect gene of a scorpion also showed resistance to diamond-back moth (Wang et al. 2005). An additional new approach for managing insect pests is RNA interference (Baum et al. 2007). However, insect-resistant GM Brassica crops are not yet commercially available (CERA - GM crop database 2014; Ahuja et al. 2010).

\section{Methods for identification of host plant resistance}

Resistance in plant genotypes to herbivores is observed frequently, but the identification of plant features contributing to the resistance in plants may be difficult (Stoner 1992). Laboratory screening methods have been developed for testing the susceptibility of different host plants to individual insect pest species (Farrell 1977; Harmon and McCaffrey 1997; Ulmer et al. 2001; Eickermann and Ulber 2010). The basis for identification of host plant resistance is the screening of a large assortment of genetically diverse genotypes. Simple, quick and reliable bioassay techniques are required to evaluate insect pest preference and performance and responses of host plants to pest attack (Ellis and Kift 2003). Standardization of test plants grown under greenhouse conditions may be equally important as standardization of test insects in obtaining reliable results (Harmon and McCaffrey 1997). To 
test insect responses to host plants two methods can be used: (i) multi-choice tests and (ii) nochoice tests (Farrell 1977; Ulmer et al. 2001; Eickermann and Ulber 2010). Multi-choice tests are applied to identify host preference and acceptance for individual plant genotypes (Bartlet and Williams 1991). No-choice tests are focused on oviposition, feeding and performance on different plant genotypes (Farrell 1977).

\section{Host selection by herbivorous insects}

The majority of herbivorous insect species accept only a limited number of plant species as hosts (Van Loon et al. 1992) and host plant selection behavior is fundamental to insect life cycles (Schoonhoven et al. 2005). Host selection by herbivorous insects is often divided into three steps (Mithen 1992; Finch and Collier 2000; Williams and Cook 2010): (i) host plant searching (finding) of the adult insects, (ii) acceptance of the plant by adults for laying eggs and (iii) continuous feeding of larvae or adults (Mithen 1992).

Olfactory cues are commonly important for host finding (Schoonhoven et al. 2005). From long distances, olfactory cues can lead the way to the host plant (Finch and Collier 2000). Most crucifer-feeding insects are attracted to specific volatile hydrolysis products of glucosinolates such as isothiocyanates and nitriles as well as to non-specific volatiles which are released from plants of various plant families (Bartlet et al. 1993; Bartlet et al. 1997; Cook et al. 2007). Previous studies reported that isothiocyanates mainly attract specialist insects of oilseed rape (Renwick et al. 1992; Van Loon et al. 1992; Chew and Renwick 1995). They are important cues for host location by cabbage seed weevil, cabbage stem flea beetle, pollen beetle, and brassicae pod midge (Bartlet et al. 1999b).

Visual cues such as colour and plant architecture may be important across intermediate distances (Smart et al. 1997; Williams and Cook 2010). Many specialist insects of oilseed rape are attracted by the yellow colour (Giamoustaris and Mithen 1996; Smart et al. 1997; Cook et al. 2013).

At close range orientation, mainly non-volatile plant metabolites are important for host acceptance (Finch and Collier 2000). For host acceptance of crucifer-feeding insects, glucosinolates which are not hydrolyzed by myrosinase and spatially separated from this enzyme play a major role (Renwick et al. 1992; Bartlet et al. 1994; Huang and Renwick 1994; Renwick 2002) and trigger oviposition by these insects (Renwick et al. 1992; Van Loon et al. 1992; Chew and Renwick 1995). For instance, oviposition by small and large white butterfly is stimulated by the indolyl glucosinolate glucobrassicin (Renwick et al. 1992; Van Loon et 
al. 1992) and oviposition by cabbage root fly is stimulated by the aromatic glucosinolate gluconasturtiin (Tansey and Dosdall 2011). Glucosinolates can also trigger feeding by specialist insects (Chew and Renwick 1995). They have been found to stimulate feeding by cabbage stem flea beetle (Giamoustaris and Mithen 1995; Bartlet et al. 1994), Ceutorhynchus constrictus (Marsh.) and C. inaffectatus Gyll. (Nielsen 1990). Feeding by larvae of cabbage stem weevil is stimulated by the indolyl glucosinolates glucobrassicin, 4methoxyglucobrassicin and by the aromatic glucosinolate gluconasturtiin (Eickermann 2011). Larval weight of cabbage stem flea beetle increased with increasing concentration of indolyl glucosinolate 4-hydoxyglucobrassicin and aromatic glucosinolate progoitrin (Doering 2012b). Feeding by cabbage flea beetles is stimulated by the indolyl glucosinolate neoglucobrassicin (Larsen et al. 1985). Feeding by cabbage stem flea beetle on an artificial medium is stimulated by the aliphatic glucosinolates gluconapin and glucotropaeolin, by the indolyl glucosinolate glucobrassicin and by the aromatic glucosinolate gluconasturtiin (Bartlet et al. 1994). However, Bartlet (1999b) revealed that the presence of glucosinolates is not a prerequisite for feeding by cabbage stem flea beetle.

On the other hand, the presence of glucosinolates in crucifer plants also has been found to serve as defense compounds against non-specific, generalist herbivores (Feeny 1977). However, even specialist insects are not completely immune to the defense compounds of brassicaceous host plants (Ali and Agrawal 2012). Glucosinolates can cause repulsion or deterrence of specialist insect pests in crucifer plants. For instance, high glucosinolate concentrations in leaves of oilseed rape result in lower numbers of cabbage aphid compared to leaves with low concentrations (Waligora and Krzymanska 1995). Feeding by cabbage flea beetle and diamond-back moth is reduced at high concentrations of glucosinolates compared to intermediate glucosinolate concentrations (Siemens and Mitchelolds 1996). Oviposition by cabbage root fly is negatively correlated with the indolyl glucosinolate neoglucobrassicin (Tansey and Dosdall 2011). Feeding by cabbage stem weevil larvae decreased with increasing indolyl glucosinolate 4-hydroxyglucobrassicin (Eickermann 2011).

Other secondary plant metabolites such as phenolics and alkaloids can affect host acceptance and preference of herbivorous insects (Mayer 2004; Schoonhoven et al. 2005). The cabbage root fly responded strongly to a compound (a complex tetracyclic carboxylic acid) from the surface of cabbage leaves (Roessingh et al. 1997). Phytoalexins such as methoxybrassicin, cyclobrassinin, and brassitin triggered oviposition by cabbage root fly (Baur et al. 1998). The natural flavonoid kaempferol has been identified to reduce larval feeding by cabbage seed weevil (Lee et al. 2014). 
Nutrient quality of the plant can affect adult abundance, oviposition preference and larval development (Blake et al. 2010). Primary plant metabolites such as sugars and amino acids can affect feeding of herbivorous insects (Bartlet et al. 1994; Van Loon and van Eeuwijk 1989). Sugars stimulated feeding by cabbage stem flea beetle on an artificial agar substrate (Bartlet et al. 1994). Carbohydrates such as sucrose, fructose and glucose stimulated feeding by herbivorous insects (Schoonhoven et al. 2005) and can affect insect preference and performance (Berenbaum 1995). For instance, the large white butterfly is stimulated by Dsucrose and D-glucose (Bernays and Simpson 1982). Nitrogen has a central role in various metabolic processes of plants e.g. for cellular structure, genetic coding and plant growth (Mattson 1980). In addition, the nitrogen content of the plant can affect herbivorous insects (Mattson 1980). Plant attractiveness can be modified by crop nitrogen status (Rusch et al. 2013), thereby affecting pest abundance on the crop (Staley et al. 2010). Foliar nitrogen content can affect performance and survival (Awmack and Leather 2002; De Bruyn et al. 2002) and limit population growth of herbivorous insects (Mattson 1980; White 1984). For instance, larval performance of diamond-back moth (Staley et al. 2009) and small white butterfly (Loader and Damman 1991; Chen et al. 2004) was enhanced when plants were fertilized with nitrogen. Fertilization rate of nitrogen can affect host acceptance by females of Pieris spp., which laid more eggs on highly fertilized plants compared to poorly fertilized plants (Chen et al. 2004). Larvae of the small white butterfly adjusted their feeding rate to maximize nitrogen accumulation rate (Slansky and Feeny 1977).

A non-biochemical factor affecting host plant selection of insects is plant morphology such as leaf color, size and position, leaf surface waxes and trichome density (Sarfraz et al. 2006). For instance, canola pods with stiff trichomes showed no damage by cabbage flea beetle (Phyllotreta cruciferae (Goeze)) (Lamb 1980). A high trichome density had adverse effects on feeding preference by cabbage flea beetles in canola (Soroka et al. 2011) and by cabbage stem flea beetle in Brassica spp. (Doering 2012a). Plants of B. oleracea with wax or non-wax surface layers can determine resistance to cabbage aphid. Non-waxy plants were not colonized by cabbage aphid (Thompson 1963). Leaf surface waxes can also contain chemical cues, including glucosinolates (Staedler et al. 1986). The physical structure of plant surface and lipids can affect attachment and locomotion of insect herbivores. Glossy phenotypes are commonly less susceptible to insect herbivores than non-glossy phenotypes (Eigenbrode and Espelie 1995). Infestation by cabbage stem weevil increased accordingly with the increasing number of plant leaves on oilseed rape (Eickermann and Ulber 2011). 
Secondary metabolites - glucosinolates (s. also pp 12-13): Glucosinolates are present in the plant order Capparales, which also includes the Brassicaceae (Rodman et al. 1996). Glucosinolates are the major group of secondary metabolites found in cruciferous crops (Fahey et al. 2001). Approximately 120 different glucosinolate compounds are known (Fahey et al. 2001; Bones and Rossiter 2006). All glucosinolates share a chemical structure consisting of a $\beta$-D-glucopyranose linked via a sulfur atom to a (Z)- $N$-hydroximinosulfate ester, plus a variable R side chain (Fig. 4) (Halkier and Gershenzon 2006). In Brassica species glucosinolates can be divided into three major classes, (i) aliphatic, (ii) indolyl and (iii) aromatic glucosinolates (Table 1) (Giamoustaris and Mithen 1995).

Glucosinolates are catalyzed by the endogenous enzyme myrosinase following disruption of plant cells (Fenwick and Heaney 1983; Hopkins et al. 2009), while in nondisrupted plant cells the myrosinase is spatially separated from the glucosinolates (Mithen 1992, 2001). Depending on the glucosinolate side chain, $\mathrm{pH}$-value, presence of ferrous ions and ascorbic acid several products can be catalyzed (Fenwick and Heaney 1983). Aliphatic glucosinolates can be hydrolyzed to stable volatile isothiocyanates, nitriles, and thiocyanates. However, the aliphatic glucosinolate progoitrin cannot be hydrolyzed to stable volatile isothiocyanates (Mithen 1992, 2001; Bones and Rossiter 2006). Indolyl glucosinolates hydrolyze to unstable non-volatile isothiocyanates and nitriles, which can be degenerated to alcohol and thiocyanate ions (Mithen 1992, 2001; Bones and Rossiter 2006).

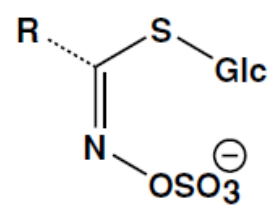

Fig. 4 Common glucosinolate structure (Halkier and Gershenzon 2006)

Glucosinolates are found in roots, stems, leaves and seeds of oilseed rape (Fahey et al. 2001) and vary both in quantitative and qualitative levels between individual plant organs (Velasco et al. 2007). Total glucosinolate content in seeds is higher compared to stems and leaves of oilseed rape (Cleemput and Becker 2012). Total glucosinolate content in leaves is positively correlated with total glucosinolate content in stems, but not with the content in seeds (Cleemput and Becker 2012). Glucosinolate content in leaves and stems of resynthesized winter oilseed rape lines can range from $0.0-5.0 \mu \mathrm{mol} / \mathrm{g} \mathrm{D}$.W. and in seeds from 20.0 - $118.0 \mu \mathrm{mol} / \mathrm{g}$ D. W. (Cleemput and Becker 2012). Advanced leave stages have lower glucosinolate contents compared to early leave stages (Brown 2003). Total 
glucosinolate content can vary with seasonal and environmental conditions, locations (Renwick 2002) and even over the course of a day (Rosa 1997). In resynthesized lines of winter oilseed rape the predominant leaf glucosinolates are the aliphatic glucosinolates (Cleemput and Becker 2012). In Arabidopsis, indolyl glucosinolates are mainly present in advanced leaf stages and in the roots (Brown 2003).

Table 1 Glucosinolates found in Brassica species according to Giamoustaris and Mithen (1995); Velasco and Becker (2000); Halkier and Gershenzon (2006); Kuebler (2010); Henning (2013)

\begin{tabular}{llll}
\hline Chemical nomenclature of the side chain & Trivial name & Abbreviation & Group \\
\hline 2-hydroxy-3-butenyl & progoitrin & PRO & aliphatic \\
2-hydroxy-4-pentenyl & napoleiferin & GNL & aliphatic \\
5-methylsulphinylpentyl & glucoalyssin & ALY & aliphatic \\
3-butenyl & gluconapin & GNA & aliphatic \\
4-pentenyl & glucobrassicanapin & GBN & aliphatic \\
2-propenyl & sinigrin & SIN & aliphatic \\
3-methylthiopropyl & glucoibervirin & IBV & aliphatic \\
3-methylsulphinylpropyl & glucoiberin & IBE & aliphatic \\
(2S) 2-hydroxy-3-butenyl & epiprogoitrin & EPI & aliphatic \\
4-methylthiobutyl & glucoerucin & ERU & aliphatic \\
4-methylsulphinylbutyl & glucoraphanin & RAA & aliphatic \\
3-methylsulphonylpropyl & glucocheirolin & CHE & aliphatic \\
4-hydroxy-3-indolylmethyl & 4-hydroxyglucobrassicin & $4 O H$ & indolyl \\
3-indolylmethyl & glucobrassicin & GBC & indolyl \\
4-methoxy-3-indolylmethyl & 4-methoxyglucobrassicin & $4 M E$ & indolyl \\
n-methoxy-3-indolylmethyl & neoglucobrassicin & NEO & indolyl \\
2-phenylethyl & gluconasturtiin & NAS & aromatic \\
p-hydroxybenzyl & sinalbin & SIB & aromatic \\
\hline
\end{tabular}

The glucosinolate content in cruciferous plants, can be induced by mechanical and herbivore disruption (Bodnaryk 1992; Bartlet et al. 1999a) or by plant chemicals (Bodnaryk 1994; Bodnaryk and Yoshihara 1995; Doughty et al. 1995; Brader et al. 2001). In Arabidopsis, disruption of the tissue by herbivory induces the biosynthesis of indolyl glucosinolates (Beekwilder et al. 2008). In oilseed rape, the application of the elicitor jasmonic acid induces indolyl glucosinolates (Bodnaryk and Yoshihara 1995; Doughty et al. 1995). In B. oleracea, the application of jasmonic acid doubles the content of the indolyl glucosinolate glucobrassicin and lowers the content of the aliphatic glucosinolate glucoiberin and the indolyl glucosinolate 4-hydroxyglucobrassicin (Bruinsma et al. 2007). Sugars such as glucose and sucrose and the amino acid DL-methionine can elicit the increase of glucosinolate contents in sprouts of Brassicaceae (Baenas et al. 2014). In seedlings of oilseed rape, feeding 
Chapter I

by cabbage flea beetle increases the content of indolyl glucosinolates glucobrassicin and 4hydroxyglucobrassicin (Bodnaryk 1992). The glucosinolate content can be also increased by sulfur application (Booth and Walker 1992). In crucifer leaves, induced changes of glucosinolate levels by insect feeding can occur within one day and last for several weeks (Bartlet et al. 1999a). Early-season herbivores can affect food quality for herbivores colonizing the plant later in the season (Bartlet et al. 1999a). Herbivores feeding on roots can systemically induce glucosinolate levels in the stems and affect performance of above-ground specialist herbivores (Van Dam et al. 2005; Soler et al. 2005). 


\section{Objectives of the study}

The major objectives of the present study were:

- To determine the susceptibility of a large assortment of genetically diverse oilseed rape (Brassica napus L.) genotypes for infestation by the specialists rape stem weevil (Ceutorhynchus napi Gyll.) and cabbage stem weevil (Ceutorhynchus pallidactylus (Marsh.)). To evaluate differences in host plant acceptance between various genotypes of oilseed rape, the number of eggs laid by rape stem weevil was assessed. To determine the host plant quality of various genotypes of oilseed rape the larval performance of rape stem weevil was assessed.

- To evaluate differences in plant responses to egg-deposition by rape stem weevil between selected genotypes of oilseed rape, the severity of pith tissue degeneration was assessed.

- To assess host plant resistance mechanisms affecting infestation by rape stem weevil, both plant metabolic and morphological plant traits were evaluated. Stems and leaves of genotypes of oilseed rape were analyzed for glucosinolates and plant nutrients such as carbon and nitrogen. Additionally, morphological plant traits such as stem base diameters and plant lengths of various genotypes and sampling dates were evaluated during the natural crop infestation period of rape stem weevil. Quantitative differences of plant resources between genotypes were evaluated by measuring plant biomasses. These morphological and metabolic plant traits were tried to correlate with the numbers of eggs laid, larval infestation and larval performance of rape stem weevil.

- The oviposition preference and larval performance of rape stem weevil on various genotypes of oilseed rape has not been studied in detail before. The overall goal of this study was to improve knowledge in resistance mechanisms, which is required for breeding cultivars of oilseed rape with resistance to insect pests. 
Chapter I

\section{References}

Agrawal AA, Kurashige NS (2003) A role for isothiocyanates in plant resistance against the specialist herbivore Pieris rapae. Journal of Chemical Ecology 29:1403-1415.

Ahuja I, Rohloff J, Bones A (2010) Defence mechanisms of Brassicaceae: implications for plant-insect interactions and potential for integrated pest management. A review. Agronomy for Sustainable Development 30:311-348.

Alford DV (2003) The oilseed rape crop. In: DV Alford (Eds.), Biocontrol of oilseed rape pests. Blackwell Science Ltd., Oxford, pp 1-8.

Alford DV, Nilsson C, Ulber B (2003) Insect pests of oilseed rape crops. In: DV Alford (Eds.), Biocontrol of oilseed rape pests. Blackwell Science Ltd., Oxford, pp 9-42.

Ali JG, Agrawal AA (2012) Specialist versus generalist insect herbivores and plant defense. Trends in Plant Science 17:293-302.

Awmack CS, Leather SR (2002) Host plant quality and fecundity in herbivorous insects. Annual Review of Entomology 47:817-844.

Baenas N, Garcia-Viguera C, Moreno DA (2014) Biotic elicitors effectively increase the glucosinolates content in Brassicaceae sprouts. Journal of Agricultural and Food Chemistry 62:1881-1889.

Ballanger Y (1987a) Nuisibilité du charancon de la tige du colza (Ceutorrhynchus napi Gyll.). Phytoma 384:35-37.

Ballanger Y (1987b) Raisonnement de la lutte contre le gros charancon de la tige du colza (Ceutorhynchus napi Gyll.). IOBC WPRS BULLETIN 4 (10):79-84.

Barari H, Cook SM, Clark SJ, Williams IH (2005) Effect of a turnip rape (Brassica rapa) trap crop on stem-mining pests and their parasitoids in winter oilseed rape (Brassica napus). Biological Control 50:69-86.

Bartlet E, Blight MM, Hick AJ, Williams IH (1993) The responses of the cabbage seed weevil (Ceutorhynchus assimilis) to the odour of oilseed rape (Brassica napus) and to some volatile isothiocyanates. Entomologia Experimentalis et Applicata 68:295-302.

Bartlet E, Blight MM, Lane P, Williams IH (1997) The responses of the cabbage seed weevil Ceutorhynchus assimilis to volatile compounds from oilseed rape in a linear track olfactometer. Entomologia Experimentalis et Applicata 85:257-262.

Bartlet E, Kiddle G, Williams I, Wallsgrove R (1999a) Wound-induced increases in the glucosinolate content of oilseed rape and their effect on subsequent herbivory by a crucifer specialist. Entomologia Experimentalis et Applicata 91:163-167. 
Bartlet E, Parsons D, Williams IH, Clark SJ (1994) The influence of glucosinolates and sugars on feeding by the cabbage stem flea beetle, Psylliodes chrysocephala. Entomologia Experimentalis et Applicata 73:77-83.

Bartlet E, Williams I (1991) Factors restricting the feeding of the cabbage stem flea beetle (Psylliodes chrysocephala). Entomologia Experimentalis et Applicata 60:233-238.

Bartlet E, Williams I, Pickett J, Ellis P, Derridj S (1999b) The ideal glucosinolate profile for pest resistance in oilseed rape. IOBC WPRS BULLETIN 22 (10):13-17.

Baum JA, Bogaert T, Clinton W, Heck GR, Feldmann P, Ilagan O, Johnson S, Plaetinck G, Munyikwa T, Pleau M (2007) Control of coleopteran insect pests through RNA interference. Nature Biotechnology 25:1322-1326.

Baur R, Staedler E, Monde K, Takasugi M (1998) Phytoalexins from Brassica (Cruciferae) as oviposition stimulants for the cabbage root fly, Delia radicum. Chemoecology 8:163168.

Becker HC, Engqvist GM, Karlsson B (1995) Comparison of rapeseed cultivars and resynthesized lines based on allozyme and RFLP markers. Theoretical and Applied Genetics 91:62-67.

Beekwilder J, van Leeuwen W, van Dam NM, Bertossi M, Grandi V, Mizzi L, Soloviev M, Szabados L, Molthoff JW, Schipper B (2008) The impact of the absence of aliphatic glucosinolates on insect herbivory in Arabidopsis. PLoS One 3:e2068.

Bell JM (1995) Meal and by-product utilization in animal nutrition. In: DS Kimber and DI Mc Gregor (Eds.), Brassica oilseeds-production and utilization. CAB International, Wallingford, pp 301-338.

Berenbaum MR (1995) Turnabout is fair play: secondary roles for primary compounds. Journal of Chemical Ecology 21:925-940.

Bernays E, Simpson S (1982) Control of food intake. Advances in Insect Physiology 16:59118.

Blake A, Dosdall L, Keddie B (2010) Plant nutrients and the spatiotemporal distribution dynamics of Ceutorhynchus obstrictus (Coleoptera: Curculionidae) and its parasitoids. Environmental Entomology 39:1195-1205.

Bodnaryk R, Yoshihara T (1995) Structure-activity relationships of cyclopentane analogs of jasmonic acid for induced responses of canola seedlings, Brassica napus L.. Journal of Chemical Ecology 21:1735-1743.

Bodnaryk RP (1992) Effects of wounding on glucosinolates in the cotyledons of oilseed rape and mustard. Phytochemistry 31:2671-2677. 
Bodnaryk RP (1994) Potent effect of jasmonates on indole glucosinolates in oilseed rape and mustard. Phytochemistry 35:301-305.

Bones AM, Rossiter JT (2006) The enzymic and chemically induced decomposition of glucosinolates. Phytochemistry 67:1053-1067.

Booth E, Walker K (1992) The effect of site and foliar sulfur on oilseed rape - comparison of sulfur responsive and nonresponsive seasons. Phyton Annales rei Botanicae 32:9-13.

Brader G, Tas E, Palva ET (2001) Jasmonate-dependent induction of indole glucosinolates in Arabidopsis by culture filtrates of the nonspecific pathogen Erwinia carotovora. Plant Physiology 126:849-860.

Brown PD (2003) Variation of glucosinolate accumulation among different organs and developmental stages of Arabidopsis thaliana. Phytochemistry 62:471-481.

Bruinsma M, van Dam NM, van Loon JJA, Dicke M (2007) Jasmonic acid-induced changes in Brassica oleracea affect oviposition preference of two specialist herbivores. Journal of Chemical Ecology 33:655-668.

Buechi R (1988) Neue Bekaempfungsschwelle fuer den Rapsstengelruessler Ceutorhynchus napi Gyll. Mitteilungen der Schweizerischen Landwirtschaft 36:110-117.

Buechi R (1990) Investigations on the use of turnip rape as trap plant to control oilseed rape pests. IOBC WPRS BULLETIN 13 (4):32-39.

Buechi R (1996) Eiablage des Rapsstengelruesslers Ceutorhynchus napi Gyll., in Abhaengigkeit der Stengellaenge bei verschiedenen Rapssorten. Anzeiger fuer Schaedlingskunde, Pflanzenschutz, Umweltschutz 69:136-139.

Buechi R (2002) Mortality of pollen beetle (Meligethes spp.) larvae due to predators and parasitoids in rape fields and the effect of conservation strips. Agriculture, Ecosystems and Environment 90:255-263.

Buechs W (2009) Trap crops as method to control pests in organic oilseed rape cultivation. Mitteilungen der Deutschen Gesellschaft fuer Allgemeine und Angewandte Entomologie 17:241-246.

BVL (2014) www.portal.bvl.bund.de/psm/jsp/. Accessed 19. January 2014.

Cárcamo H, Dunn R, Dosdall L, Olfert O (2007a) Managing cabbage seedpod weevil in canola using a trap crop: A commercial field scale study in western Canada. Crop Protection 26:1325-1334.

Cárcamo H, Olfert O, Dosdall L, Herle C, Beres B, Soroka J (2007b) Resistance to cabbage seedpod weevil among selected Brassicaceae germplasm. The Canadian Entomologist 139:658-669. 
CERA - GM crop database (2014) http://cera-gmc.org/index.php?action=gm_crop_database. Accessed 23. January 2014.

Chen Y-Z, Lin L, Wang C-W, Yeh C-C, Hwang S-Y (2004) Response of two Pieris (Lepidoptera: Pieridae) species to fertilization of a host plant. Zoological Studies 43:778-786.

Chew F, Renwick J (1995) Host plant choice in Pieris butterflies. In: RT Carde and WJ Bell (Eds.), Chemical Ecology of Insects 2. Chapman and Hall, New York, Victoria, Scarborough, Col. Polanco, pp 214-238.

Cleemput S, Becker HC (2012) Genetic variation in leaf and stem glucosinolates in resynthesized lines of winter rapeseed (Brassica napus L.). Genetic Resources and Crop Evolution 59:539-546.

Cook S, Smart L, Potting R, Bartlet E, Martin J, Murray D, Watts N, Williams I (2002) Turnip rape (Brassica rapa) as a trap crop to protect oilseed rape (Brassica napus) from infestation by insect pests: potential and mechanisms of action. Proc BCPC Cong: Pest and Diseases, Brighton, United Kingdom, 18-21 November 2002, (2):569574.

Cook SM, Rasmussen H, Birkett M, Murray D, Pye B, Watts N, Williams IH (2007) Behavioural and chemical ecology underlying the success of turnip rape (Brassica rapa) trap crops in protecting oilseed rape (Brassica napus) from the pollen beetle (Meligethes aeneus). Arthropod-Plant Interactions 1:57-67.

Cook SM, Skellern MP, Doering TF, Pickett JA (2013) Red oilseed rape? The potential for manipulation of petal colour in control strategies for the pollen beetle (Meligethes aeneus). Arthropod-Plant Interactions 7:249-258.

De Bruyn L, Scheirs J, Verhagen R (2002) Nutrient stress, host plant quality and herbivore performance of a leaf-mining fly on grass. Oecologia 130:594-599.

Dechert G, Ulber B (2004) Interactions between the stem-mining weevils Ceutorhynchus napi Gyll. and Ceutorhynchus pallidactylus (Marsh.) (Coleoptera: Curculionidae) in oilseed rape. Agricultural and Forest Entomology 6:193-198.

Derron J, Le Clech E, Bezençon N, Goy G (2004) Résistance des méligèthes du colza aux pyréthrinoïdes dans le bassin lémanique. Revue Suisse d'Agriculture 36:237-242.

Deubert K-H (1952) Ueber das durch die Eiablage von Ceutorrhynchus napi Gyll. (Col. Curc.) verursachte histologische Schadbild an Winterraps. Wissenschaftliche Zeitschrift der Martin-Luther-Universitaet Halle-Wittenberg 2:203-205. 
Deubert K-H (1955) Beitraege zu den Beziehungen zwischen Ceutorrhynchus napi Gyll. (Col. Curc.) und Winterraps hinsichtlich der Gallenbildung mit Ovarienuntersuchungen an verschiedenen Ceutorrhynchus-Arten. Wissenschaftliche Zeitschrift der Martin-Luther-Universitaet Halle-Wittenberg 5:909-932.

Dickson M, Eckenrode C (1975) Variation in Brassica oleracea resistance to cabbage looper and imported cabbage worm in the greenhouse and field. Journal of Economic Entomology 68:757-760.

Dickson M, Eckenrode C, Lin J (1986) Breeding for diamond-back moth resistance in Brassica oleracea. Proc Intern Diamondback Moth Management Cong, Shanhua, Taiwan, 471:137-143.

Diederichsen E, Sacristan M (1991) Resynthesis of amphidiploid Brassica species and their clubroot disease reaction. Proc Rapeseed Cong, Saskatoon, Canada, 9-11 July 1991, 1: 274-279.

Doering A (2012a) Effects of host plant characteristics on the feeding preference of adult cabbage stem flea beetle (Psylliodes chrysocephala L.). In: A Doering (Eds.), Effect of plant characteristics on host selection and larval performance of specialist insect pests on Brassicaceae. Cuvillier, Goettingen, pp 37-57.

Doering A (2012b) Performance of cabbage stem flea beetle larvae (Psylliodes chrysocephala L.) on brassicaceous host plants with different glucosinolate profile. In: A Doering (Eds.), Effect of plant characteristics on host plant selection and larval performance of specialist insect pests on Brassicaceae. Cuvillier, Goettingen, pp 19-35.

Dosse G (1951) Der grosse Kohltriebruessler Ceuthorrhynchus napi Gyll. Biologie, Schadenauftreten und Bekaempfung unter besonderer Beruecksichtigung. der "Gallbildung" an Kohlpflanzen: Mit 41 Abb.. Zeitschrift fuer Angewandte Entomologie 32:32-566.

Doughty KJ, Kiddle GA, Pye BJ, Wallsgrove RM, Pickett JA (1995) Selective induction of glucosinolates in oilseed rape leaves by methyl jasmonate. Phytochemistry 38:347350.

Duran C, Edwards D, Batley J (2009) Genetic maps and the use of synteny. In: DJ Somers, P Langridge and JP Gustafson (Eds.), Plant genomics. Humana, New York, pp 41-55.

Eickermann M (2011) Resynthesized lines and cultivars of Brassica napus L. provide sources of resistance to the cabbage stem weevil (Ceutorhynchus pallidactylus (Mrsh.)). Bulletin of Entomological Research 101:287-294. 
Eickermann M, Ulber B (2010) Screening of oilseed rape and other brassicaceous genotypes for susceptibility to Ceutorhynchus pallidactylus (Mrsh.). Journal of Applied Entomology 134:542-550.

Eickermann M, Ulber B (2011) Effect of plant architecture on infestation of Brassica genotypes by cabbage stem weevil, Ceutorhynchus pallidactylus (Mrsh.). Proc Intern Rapeseed Cong, Prague, Czech Republic, 5-9 June 2011, CD-Rom.

Eigenbrode SD, Espelie KE (1995) Effects of plant epicuticular lipids on insect herbivores. Annual Review of Entomology 40:171-194.

Ellis P, Farrell J (1995) Resistance to cabbage aphid (Brevicoryne brassicae) in six Brassica accessions in New Zealand. New Zealand Journal of Crop and Horticultural Science 23:25-29.

Ellis P, Kift N (2003) The exploitation of plant resistance in controlling insect pests of vegetable crops. IOBC WPRS BULLETIN 26 (3):47-55.

Eurostat

(2014) http://epp.eurostat.ec.europa.eu/portal/page/portal/agriculture/data/main_tables. Accessed 15. January 2014.

Fahey JW, Zalcmann AT, Talalay P (2001) The chemical diversity and distribution of glucosinolates and isothiocyanates among plants. Phytochemistry 56:5-51.

Farrell J (1977) Plant resistance to insects and the selection of resistant lines. New Zealand Entomologist 6:244-261.

Feeny P (1977) Defensive ecology of the cruciferae. Annals of the Missouri Botanical Garden 64:221-234.

Fenwick G, Heaney R (1983) Glucosinolates and their breakdown products in cruciferous crops, foods and feedingstuffs. Food Chemistry 11:249-271.

Finch S (1977) Monitoring insect pests of cruciferous crops. Proc BCPC Cong: Pests and Diseases, Croydon, United Kingdom, 1: 219-226.

Finch S, Collier R (2000) Host-plant selection by insects - a theory based on 'appropriate/inappropriate landings' by pest insects of cruciferous plants. Entomologia Experimentalis et Applicata 96:91-102.

Frauen M (2011) Zuchtziele. In: O Christen und W Friedt (Eds.), Winterraps, das Handbuch fuer Profis. DLG, Frankfurt am Main, pp 25-30.

Freier B, Sellmann J, Schwarz J, Klocke B, Kehlenbeck H, Zornbach W (2014) Netz Vergleichsbetriebe Pflanzenschutz-Jahresbericht 2012 - Analyse der Ergebnisse der Jahre 2007 bis 2012. JKI Berichte 172:1-111. 
Friedt W (2011) Ausgangsmaterial. In: O Christen und W Friedt (Eds.), Winterraps, das Handbuch fuer Profis. DLG, Frankfurt am Main, pp 20-25.

Giamoustaris A, Mithen R (1996) The effect of flower colour and glucosinolates on the interaction between oilseed rape and pollen beetles. Entomologia Experimentalis et Applicata 80:206-208.

Giamoustaris A, Mithen R (1997) Glucosinolates and disease resistance in oilseed rape (Brassica napus ssp. oleifera). Plant Pathology 46:271-275.

Giamoustaris A, Mithen R ( 1995) The effect of modifying the glucosinolate content of leaves of oilseed rape (Brassica napus ssp. oleifera) on its interaction with specialist and generalist pests. Annals of Applied Biology 126:347-363.

Girke A, Schierholt A, Becker HC (2012). Extending the rapeseed genepool with resynthesized Brassica napus L. I: genetic diversity. Genetic Resources and Crop Evolution 59:1441-1447.

Guenthart E (1949) Beitraege zur Lebensweise und Bekaempfung von Ceutorrhynchus quadridens Panz. und Ceutorrhynchus napi Gyll. mit Beobachtungen an weiteren Kohl- und Rapsschaedlingen. Mitteilungen der Schweizerischen Entomologischen Gesellschaft 22:441-591.

Gullan PJ, Cranston PS (2005) The insects - an outline of entomology. Blackwell, Malden, Oxford, Victoria.

Halkier BA, Gershenzon J (2006) Biology and biochemistry of glucosinolates. Annual Review of Plant Biology 57:303-333.

Hansen LM (2003) Insecticide-resistant pollen beetles (Meligethes aeneus F.) found in danish oilseed rape (Brassica napus L.) fields. Pest Management Science 59:1057-1059.

Harmon BL, McCaffrey JP (1997) Laboratory bioassay to assess Brassica spp. germplasm for resistance to the cabbage seedpod weevil (Coleoptera: Curculionidae). Journal of Economic Entomology 90:1392-1399.

Heimbach U, Mueller A (2013) Incidence of pyrethroid-resistant oilseed rape pests in Germany. Pest Management Science 69:209-216.

Henning K (2013) Plant science meets food science: genetic effects of glucosinolate degregation under food processing in Brassica. Dissertation, University of Wageningen, Wageningen.

Hilker M, Rohfritsch O, Meiners T (2002) The plant's response towards insect egg deposition. In: M Hilker and T Meiners (Eds.), Chemoecology of insect eggs and egg deposition. Blackwell, Berlin, Vienna, pp 205-233. 
Hopkins RJ, van Dam NM, van Loon JJA (2009) Role of glucosinolates in insect-plant relationships and multitrophic interactions. Annual Review of Entomology 54:57-83.

Huang X, Renwick J (1994) Relative activities of glucosinolates as oviposition stimulants for Pieris rapae and P. napi oleracea. Journal of Chemical Ecology 20:1025-1037.

James C (2003) Global review of commercialized transgenic crops. Current Science 84:303309.

Jin R-G, Liu Y-B, Tabashnik B, Borthakur D (2000) Development of transgenic cabbage (Brassica oleracea var. capitata) for insect resistance by Agrobacterium tumefaciensmediated transformation. In Vitro Cellular and Developmental Biology-Plant 36:231237.

Kelm M, Klukowski Z (2000) The effect of stem weevil (Ceutorhynchus pallidactylus Marsh.) infestation on oilseed rape yield. IOBC WPRS Bulletin 23 (6):125-130.

Kimber DS, Mc Gregor DI (1995) The species and their origin, cultivation and world production. In: DS Kimber and DI McGregor (Eds.), Brassica oilseeds-production and utilization. CAB International, Wallingford, pp 1-8.

Kogan M, Ortman EF (1978) Antixenosis - a new term proposed to define painters nonpreference modality of resistance. Bulletin of the Entomological Society of America 24:175-176.

Kuebler K (2010) Analyse von Glucosinolaten und Isothiocyanaten mittels Fluessigkeitschromatographie- bzw. Gaschromatographie-Massenspektrometrie. Dissertation, Justus-Liebig-Universitaet, Gießen.

Lamb R (1980) Hairs protect pods of mustard (Brassica hirta 'Gisilba') from flea beetle feeding damage. Canadian Journal of Plant Science 60:1439-1440.

Lambdon P, Hassall M, Mithen R (1998) Feeding preferences of woodpigeons and fleabeetles for oilseed rape and turnip rape. Annals of Applied Biology 133:313-328.

Larsen LM, Nielsen JK, Ploeger A, Sorensen H (1985) Responses of some beetle species to varieties of oilseed rape and to pure glucosinolates. In: H Sorensen (Eds.), Advances in the production and utilization of cruciferous crops. Martinus Nijhoff / Dr W Junk Publishers, Dordrecht, Boston, Lancaster, pp 230-244.

Le Pape H, Bronner R (1987) The effects of Ceutorhynchus napi (Curculionidae, Coleoptera) on stem tissue of Brassica napus var. oleifera. In: V Labeyrie, G Fabres and D Lachaise (Eds.), Insect-plants. Dr W Junk, Dordrecht, pp 207-212.

Lee RW, Malchev IT, Rajcan I, Kott LS (2014) Identification of putative quantitative trait loci associated with a flavonoid related to resistance to cabbage seedpod weevil 
(Ceutorhynchus obstrictus) in canola derived from an intergeneric cross, Sinapis alba $\times$ Brassica napus. Theoretical and Applied Genetics 127:419-428.

Lerin J (1993) Influence of the growth rate of oilseed rape on the splitting of the stem after an attack of Ceutorhynchus napi Gyll. IOBC WPRS BULLETIN 16 (9):160-163.

Liu C-W, Lin C-C, Yiu J-C, Chen JJ, Tseng M-J (2008) Expression of a Bacillus thuringiensis toxin (cry1Ab) gene in cabbage (Brassica oleracea L. var. capitata L.) chloroplasts confers high insecticidal efficacy against Plutella xylostella. Theoretical and Applied Genetics 117:75-88.

Loader C, Damman H (1991) Nitrogen content of food plants and vulnerability of Pieris rapae to natural enemies. Ecology 75:1586-1590.

Mattson WJ (1980) Herbivory in relation to plant nitrogen content. Annual Review of Ecology and Systematics 11:119-161.

Mauchline AL, Cook SM, Powel W, Osborne JL (2013) Effects of non-host plant odour on Meligethes aeneus during immigration to oilseed rape. Entomologia Experimentalis et Applicata 146: 313-320.

Mauchline AL, Osborne JL, Martin AP, Poppy GM, Powell W (2005) The effects of non-host plant essential oil volatiles on the behaviour of the pollen beetle Meligethes aeneus. Entomologia Experimentalis et Applicata 114:181-188.

Mayer AM (2004) Resistance to herbivores and fungal pathogens: variations on a common theme? A review comparing the effect of secondary metabolites, induced and constitutive, on herbivores and fungal pathogens. Israel Journal of Plant Sciences 52:279-292.

Messina FJ, Bloxham AJ (2004) Plant resistance to the Russian wheat aphid: effects on a nontarget aphid and the role of induction. Canadian Entomologist 136:129-137.

Mielke T (2011) Der Weltmarkt fuer Rapssaat. In: O Christen und W Friedt (Eds.), Winterraps, das Handbuch fuer Profis. DLG, Frankfurt am Main, pp 262-272.

Mithen R (1992) Leaf glucosinolate profiles and their relationship to pest and disease resistance in oilseed rape. Euphytica 63:71-83.

Mithen R (2001) Glucosinolates-biochemistry, genetics and biological activity. Plant Growth Regulation 34:91-103.

Nicolas SD, Leflon M, Monod H, Eber F, Coriton O, Huteau V, Chèvre A-M, Jenczewski E (2009) Genetic regulation of meiotic cross-overs between related genomes in Brassica napus haploids and hybrids. The Plant Cell 21:373-385. 
Nielsen JK (1990) Plant chemicals influencing host plant specificity in Ceutorhynchus species feeding on Curciferae. Proc Symposium on insect-plant relationships, Budapest, Hungary, 3-8 July 1989, 39: 209-214.

Nilsson C (2004) Trap plants to avoid insecticide application against pollen beetles in oilseed rape. IOBC WPRS BULLETIN 27 (10):215-221.

Nilsson C (2010) Impact of soil tillage on parasitoids of oilseed rape pests. In: IH Williams (Eds.), Biocontrol-based integrated managment of oilseed rape pests. Springer Science and Business Media B. V., Dordrecht, Heidelberg, London, New York, pp 305-312.

Nitzsche O, Ulber B (1998) Influence of different tillage treatments following the harvest of oilseed rape on the mortality of pollen beetle (Meligethes spp.) parasitoids. Zeitschrift fuer Pflanzenkrankheiten und Pflanzenschutz 105:417-421.

Nuss H (2004) Einfluss der Pflanzedichte und -architektur auf Abundanz und innnerpflanzliche Verteilung staengelminierender Schadinsekten in Winterraps. Dissertation, Georg-August Universitaet, Goettingen.

Olsson G (1960) Species crosses within the genus Brassica. Hereditas 46:351-386.

Olsson G, Ellerstrom S, Tsunoda S, Hinata K, Gomez-Campo C (1980) Polyploidy breeding in Europe. In: S Tsunoda, K Hinata and C Gomez-Campo (Eds.), Brassica crops and wild allies. Scientific Society Press, Tokyo, pp 167-190.

Painter RH (1951) Insect resistance in crop plants. MacMillan, New York.

Paul H (2003) Raps-Krankheiten, Schaedlinge, Schadpflanzen. Agro Concept GmbH, Soest.

Renwick JAA (2002) The chemical world of crucivores: lures, treats and traps. Entomologia Experimentalis et Applicata 104:35-42.

Renwick JAA, Radke CD, Sachdev-Gupta K, Staedler E (1992) Leaf surface chemicals stimulating oviposition by Pieris rapae (Lepidoptera: Pieridae) on cabbage. Chemoecology 3:33-38.

Rodman JE, Karol KG, Price RA, Sytsma KJ (1996) Molecules, morphology, and dahlgren's expanded order capparales. Systematic Botany 21:289-307.

Roeder K, Schwaehn P, Uffrecht B (1980) Der Einfluß acker- und pflanzenbaulicher sowie klimatischer Faktoren auf das Auftreten ausgewaehlter Schaderreger im Winterraps. Akademie der Landwirtschaftswissenschaften 181:157-162.

Roessingh P, Staedler E, Baur R, Hurter J, Ramp T (1997) Tarsal chemoreceptors and oviposition behaviour of the cabbage root fly (Delia radicum) sensitive to fractions and new compounds of host-leaf surface extracts. Physiological Entomology 22:140148. 
Rosa EA (1997) Daily variation in glucosinolate concentrations in the leaves and roots of cabbage seedlings in two constant temperature regimes. Journal of the Science of Food and Agriculture 73:364-368.

Rusch A, Valantin-Morison M, Sarthou J, Roger-Estrade J (2013) Effect of crop management and landscape context on insect pest populations and crop damage. Agriculture, Ecosystems and Environment 166:118-125.

Rygulla W, Snowdon R, Eynck C, Koopmann B, von Tiedemann A, Luehs W, Friedt W (2007) Broadening the genetic basis of Verticillium longisporum resistance in Brassica napus by interspecific hybridization. Phytopathology 97:1391-1396.

Sarfraz M, Dosdall L, Keddie B (2006) Diamond-back moth - host plant interactions: implications for pest management. Crop Protection 25:625-639.

Schmutterer H (1956) Zur Lebensweise und Bekaempfung des Großen Rapsstengelruesslers Ceutorrhynchus napi (Gyll.). Zeitschrift fuer Angewandte Entomologie 39:302-315.

Schoonhoven LM, van Loon JJA, Dicke M (2005) Insect-plant biology. Oxford University Press, Oxford.

Seyis F, Friedt W, Luehs W (2001) Resynthese-Raps (Brassica napus L.) als genetische Ressource fuer die Qualitaets- und Ertragszuechtung. Schriften zu Genetischen Ressourcen 16:91-112.

Siemens DH, Mitchelolds T (1996) Glucosinolates and herbivory by specialists (Coleoptera: Chrysomelidae, Lepidoptera: Plutellidae): consequences of concentration and induced resistance. Environmental Entomology 25:1344-1353.

Singh DP, Singh A (2005) Disease and insect resistance in plants. Science Publishers, Enfield. Slansky Jr F, Feeny P (1977) Stabilization of the rate of nitrogen accumulation by larvae of the cabbage butterfly on wild and cultivated food plants. Ecological Monographs 44:209-228.

Smart L, Blight M, Hick A (1993) Development of a monitoring system for the cabbage seed weevil and the pollen beetle. WPRS BULLETIN 16 (10):351-351.

Smart LE, Blight MM, Hick AJ (1997) Effect of visual cues and a mixture of isothiocyanates on trap capture of cabbage seed weevil, Ceutorhynchus assimilis. Journal of Chemical Ecology 23:889-902.

Smith CM, Khan ZR, Pathak MD (1994) Techniques for evaluating insect resistance in crop plants. CRC press, Boca Raton.

Snowdon RJ (2007) Cytogenetics and genome analysis in Brassica crops. Chromosome Research 15:85-95. 
Snowdon RJ, Friedt W (2004) Molecular markers in Brassica oilseed breeding: current status and future possibilities. Plant Breeding 123:1-8.

Soler R, Bezemer T, van der Putten WH, Vet LE, Harvey JA (2005) Root herbivore effects on above-ground herbivore, parasitoid and hyperparasitoid performance via changes in plant quality. Journal of Animal Ecology 74:1121-1130.

Song K, Osborn TC (1992) Polyphyletic origins of Brassica napus: new evidence based on organelle and nuclear RFLP analyses. Genome 35:992-1001.

Soroka JJ, Holowachuk JM, Gruber MY, Grenkow LF (2011) Feeding by flea beetles (Coleoptera: Chrysomelidae; Phyllotreta spp.) is decreased on canola (Brassica napus) seedlings with increased trichome density. Journal of Economic Entomology 104:125-136.

Staedler E, Juniper B, Southwood SR (1986) Oviposition and feeding stimuli in leaf surface waxes. In: B Juniper and R Southwood (Eds.), Insects and the plant surface. Edward Arnold, London, pp 105-121.

Staley JT, Stewart-Jones A, Pope TW, Wright DJ, Leather SR, Hadley P, Rossiter JT, van Emden HF, Poppy GM (2010) Varying responses of insect herbivores to altered plant chemistry under organic and conventional treatments. Proceedings of the Royal Society B: Biological Sciences 277:779-786.

Staley JT, Stewart-Jones A, Poppy GM, Leather SR, Wright DJ (2009) Fertilizer affects the behaviour and performance of Plutella xylostella on brassicas. Agricultural and Forest Entomology 11:275-282.

Stoner KA (1990) Glossy leaf wax and plant resistance to insects. Environmental Entomology 19:730-739.

Stoner KA (1992) Bibliography of plant resistance to arthropods in vegetables, 1977-1991. Phytoparasitica 20:125-138.

Tansey JA, Dosdall LM (2011) Differential responses by some insect pests to novel insectresistant Brassica napus L.. Proc Intern Rapeseed Cong, Prague, Czech Republic, 5-9 July 2011, CD-ROM.

Thieme T, Heimbach U, Mueller A (2010) Chemical control of insect pests and insecticide resistance in oilseed rape. In: IH Williams (Eds.), Biocontrol-based integrated management of oilseed rape pests. Springer Science and Business Media B.V., Dordrecht, Heidelberg, London, New York, pp 313-336.

Thompson KF (1963) Resistance to the cabbage aphid (Brevicoryne brassicae) in Brassica plants. Nature 198:209-209. 
Uddin MM, Ulrichs C, Tokuhisa JG, Mewis I (2009) Impact of glucosinolate structure on the performance of the crucifer pest Phaedon cochleariae (F.). Journal of Applied Botany and Food Quality 82:108-113.

Ulber B, Klukowski Z, Williams IH (2010) Impact of insecticides on parasitoids of oilseed rape pests. In: IH Williams (Eds.), Biocontrol-based integrated pest management of oilseed rape pests. Springer Science and Business Media B. V., Dordrecht, Heidelberg, London, New York, pp 337-356.

Ulmer B, Gillott C, Erlandson M (2001) Feeding preferences, growth and development of Mamestra configurata (Lepidoptera: Noctuidae) on Brassicaceae. The Canadian Entomologist 133:509-519.

Uppstroem B (1995) Seed chemistry. In: DS Kimber and DI Mc Gregor (Eds.), Brassica oilseeds production and utilization. CAB International, Wallingford, pp 217-242.

Van Dam NM, Raaijmakers CE, van der Putten WH (2005) Root herbivory reduces growth and survival of the shoot feeding specialist Pieris rapae on Brassica nigra. Entomologia Experimentalis et Applicata 115:161-170.

Van Loon JJA, van Eeuwijk F (1989) Chemoreception of amino acids in larvae of two species of Pieris. Physiological Entomology 14:459-469.

Van Loon JJA, Blaakmeer A, Griepink FC, van Beek TA, Schoonhoven LM, de Groot A (1992) Leaf surface compound from Brassica oleracea (Cruciferae) induces oviposition by Pieris brassicae (Lepidoptera: Pieridae). Chemoecology 3:39-44.

Velasco L, Becker HC (2000) Variability for seed glucosinolates in a germplasm collection of the genus Brassica. Genetic Resources and Crop Evolution 47:231-238.

Velasco P, Cartea ME, González C, Vilar M, Ordás A (2007) Factors affecting the glucosinolate content of kale (Brassica oleracea acephala group). Journal of Agricultural and Food Chemistry 55:955-962.

Waligora D, Krzymanska J (1995) Biological activity of glucosinolates isolated from rape Brassica napus L. to some insects. Proc Rapeseed Cong, Cambridge, United Kingdom, 4-7 July 1995, 9: 1022-1024.

Walters KFA, Young JEB, Kromb B, Cox PD (2003) Management of oilseed rape pests. In: DV Alford (Eds.), Biocontrol of oilseed rape pests. Blackwell Science Ltd., Oxford, pp 43-72.

Wang J, Chen Z, Du J, Sun Y, Liang A (2005) Novel insect resistance in Brassica napus developed by transformation of chitinase and scorpion toxin genes. Plant Cell Reports 24:549-555. 
Way MJ, Murdie G (1965) An example of varietal variations in resistance of brussels sprouts. Annals of Applied Biology 56:326-328.

White $\mathrm{T}$ (1984) The abundance of invertebrate herbivores in relation to the availability of nitrogen in stressed food plants. Oecologia 63:90-105.

Williams IH (2010) The major insect pests of oilseed rape in Europe and their management: an overview. In: IH Williams (Eds.), Biocontrol-based integrated management of oilseed rape pests. Springer Science and Business Media B.V., Dordrecht, Heidelberg, London, New York, pp 1-43.

Williams IH, Cook SM (2010) Crop location by oilseed rape pests and host location by their parasitoids. In: IH Williams (Eds.), Biocontrol-based integrated management of oilseed rape pests. Springer Science and Business Media B. V., Dordrecht, Heidelberg, London, New York, pp 215-249.

Zimmer CT, Koehler H, Nauen R (2014) Baseline susceptibility and insecticide resistance monitoring in European populations of Meligethes aeneus and Ceutorhynchus assimilis collected in winter oilseed rape. Entomologia Experimentalis et Applicata 150:279-288.

Zimmer CT, Nauen R (2011) Pyrethroid resistance and thiacloprid baseline susceptibility of European populations of Meligethes aeneus (Coleoptera: Nitidulidae) collected in winter oilseed rape. Pest Management Science 67:599-608. 


\section{CHAPTER II}

Effect of various genotypes of oilseed rape (Brassica napus L.) on larval infestation and performance of rape stem weevil (Ceutorhynchus napi Gyll.)

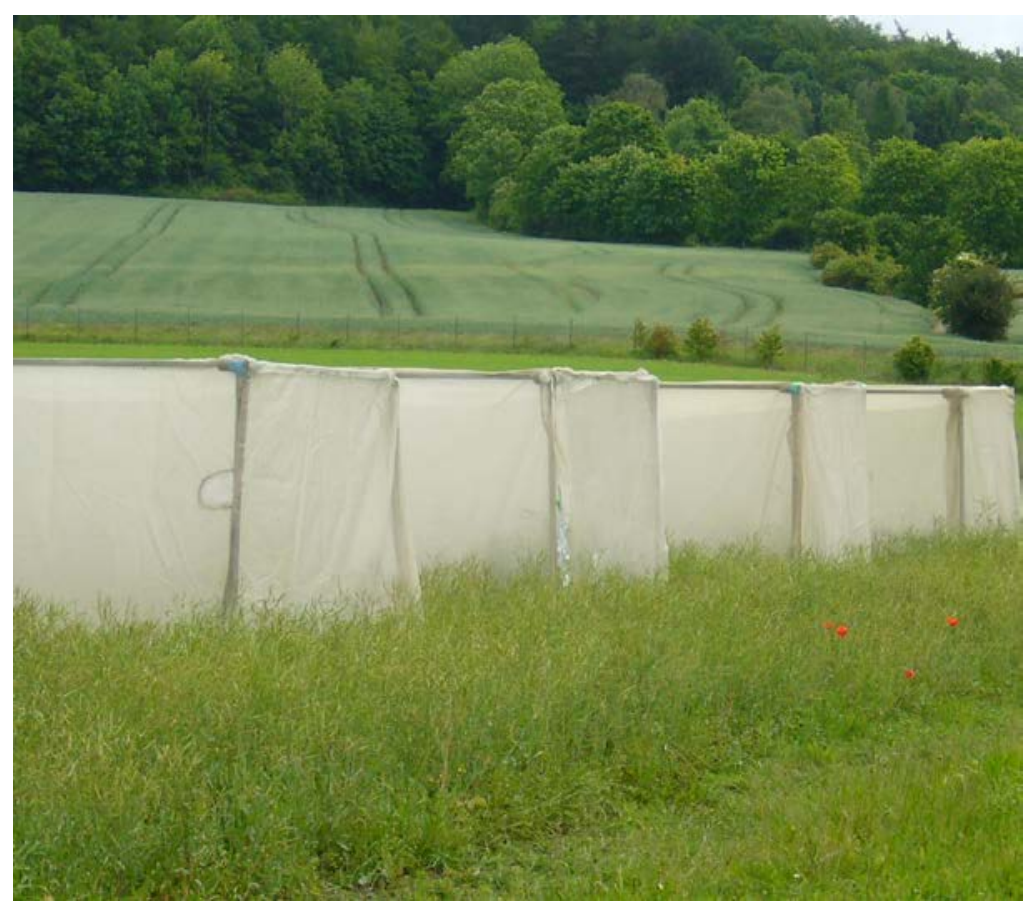




\section{Abstract}

The susceptibility of twelve genotypes of oilseed rape (Brassica napus L.), showing a broad genetic variability, was evaluated for infestation by larvae of rape stem weevil (Ceutorhynchus napi Gyll.). Three cultivars, three lines and six resynthesized lines of oilseed rape were grown in a semi-field experiment in 2011/2012. To determine differences in the susceptibility of test genotypes, the number of $C$. napi larvae was assessed. Differences in the larval performance between test genotypes were assessed by the larval instar index and the dry body mass of larvae. While the resynthesized line L16 and L122 and the cultivars Express617 and Visby were highly susceptible to C. napi, significantly lower larval numbers indicated antixenosis resistance in the resynthesized line S30. A significantly lower larval instar index in resynthesized lines S30 and L122, cultivar Campala and the line Goe1991 compared to larval instar index in resynthesized line L16 indicated antibiosis resistance in these genotypes. To determine resistance mechanisms of the tested genotypes, morphological and plant metabolic traits were assessed. The number of larvae per main stem was not dependent upon morphological plant traits such as the length of stems at the beginning of the oviposition period of $C$. napi and the basal stem diameter of full-grown stems, as well as plant densities of genotypes. The number of larvae was dependent upon the stem injury coefficient. The multivariate Partial Least Squares - Discriminant Analysis and the associated MANOVA revealed that the glucosinolate profiles of non-infested stems significantly differed between the tested genotypes. The multivariate Partial Least Squares Regression revealed no relationship between the number of larvae in stems and the glucosinolate profile of noninfested stems.

\section{Keywords}

Brassicaceae, resynthesized lines, secondary metabolites, glucosinolates, Curculionidae, host plant resistance, larval instar index

\section{Introduction}

The univoltine rape stem weevil, Ceutorhynchus napi Gyll. (Col., Curculionidae), is a major pest of winter oilseed rape (Brassica napus L.) in Europe (Alford et al. 2003). Significant yield losses can be caused by egg deposition and larval feeding within stem pith tissue (Dosse 1951; Buechi 1988). The life cycle of $C$. napi has been studied by several authors (Guenthart 1949; Dosse 1951; Deubert 1952; Scherf 1964; Le Pape and Bronner 
1987). Adults migrate to oilseed rape crops in early spring. In March/April, after approximately two weeks of feeding, females deposit single eggs into elongating stems of oilseed rape plants. Larvae feed within the stem pith. In May/June, the full-grown larvae leave the plant to pupate in soil. Adult weevils overwinter within earthen pupal cocoons. Females pass through an obligate, pre-reproductive diapause before they migrate to new crops in the following spring.

In integrated pest management systems, resistant cultivars are needed to minimize the number of insecticide applications (Williams 2004). The susceptibility of different B. napus genotypes to $C$. napi infestation and their potential as sources of resistance has not been studied in detail. Preliminary field observations indicated only minor variation between the infestation levels by C. napi on different cultivars and lines of oilseed rape (Mrowczynski 1998; Luehs et al. 2003; Dechert and Ulber 2004). Oilseed rape has originated from hybridization between cabbage (Brassica oleracea L.) and turnip (B. rapa L.) (Olsson 1960). The currently used breeding material of oilseed rape is derived from only a few interspecific hybrid plants, which occurred spontaneously some centuries ago (Becker et al. 1995). Resynthesized lines developed by interspecific crossing of the two progenitor species are broadening the genetic variation in oilseed rape (Olsson et al. 1980; Girke et al. 2012). The potential of resynthesized lines as sources for disease resistance has been reported in several studies (Diederichsen and Sacristan 1996; Rygulla et al. 2007). Therefore it is reasonable to improve pest resistance by resynthesized lines (Seyis et al. 2001; Eickermann 2011). Both metabolic plant compounds (e.g. glucosinolates) and morphological plant traits might contribute to herbivore resistance in Brassica crops (Sarfraz et al. 2006). The stem length was found to influence the attractiveness of oilseed rape to C. napi (Buechi 1996). Glucosinolates are the characteristic secondary compounds of Brassica species (Fahey et al. 2001; Bones and Rossiter 2006). They can play an important role in the acceptability of Brassica species to several insects (Ulmer and Dosdall 2006) and can affect host finding, feeding, oviposition and development of some Brassica pests (Giamoustaris and Mithen 1995; Schoonhoven et al. 2005; Ulmer and Dosdall 2006). Additionally, host acceptance of insects attacking Brassica crops, can be affected by non-volatile and volatile glucosinolates (Staedler and Reifenrath 2009). The ideal glucosinolate profile of oilseed rape for pest resistance was suggested by Bartlet at al. (1999b).

The objective of this study was to evaluate the susceptibility of twelve genotypes of oilseed rape (B. napus) for infestation by $C$. napi and to identify new sources of resistance, focusing on resynthesized lines and cultivars of oilseed rape. Plant infestation by C. napi 
larvae was studied in a semi-field experiment to determine the influence of these genotypes on the oviposition preference of $C$. napi. Larval development and feeding damage were evaluated to analyze larval performance of $C$. napi in response to these genotypes. Morphological plant traits and glucosinolate contents were analyzed as potential plant cues affecting oviposition, larval infestation levels and larval development of $C$. napi in the field.

\section{Material and Methods}

The susceptibility of twelve genotypes of B. napus (Table 1) for C. napi was examined in a semi-field experiment at the experimental station of Georg-August University (N51³3'53.8 E956’48.8) in 2011/2012. These genotypes were selected based on preliminary results and contrasting glucosinolate contents in seeds and stems (Girke 2002; Cleemput and Becker 2012). The tested B. napus genotypes were sown in single rows of $2 \mathrm{~m}$ length $\left(20\right.$ seeds $\mathrm{m}^{-1}$ ) and $25 \mathrm{~cm}$ row spacing on August $18^{\text {th }}$ in 2011 . In each of the six replicated plots, rows of the 12 genotypes were arranged at random. To avoid edge effects, two rows of winter oilseed rape cultivar Krypton were sown at the margins. Only nine $B$. napus genotypes could be evaluated, because of high winter mortality of three genotypes (Table 1).

Insect-proof gauze cages (SeranPVDC, mesh width $425 \mu \mathrm{m}$ ) measuring $4.0 \times 2.0 \times 1.8 \mathrm{~m}$ were installed on each plot on February $22^{\text {nd }}$ 2012, before the natural crop colonization of $C$. napi and other oilseed rape pests. On March $23^{\text {rd }}$, at the beginning of the natural crop colonization of $C$. napi and simultaneously with stem elongation of tested genotypes, 60 females and 30 males of post-diapause C. napi weevils were released into each cage. Weevils used for the experiment were collected from oilseed rape crops on March $3^{\text {rd }}$, and maintained in plastic boxes in a climatic chamber at $6{ }^{\circ} \mathrm{C}$ (L16:D8). They were supplied with leaves of the spring oilseed rape cultivar Mozart grown in a glasshouse.

The plant density of the genotypes was evaluated by counting all plants per plot. The BBCH growth stage (Lancashire et al. 1991) and the length of the stem were assessed from five randomly selected plants per plot and genotype at the beginning of the oviposition of $C$. napi on March $31^{\text {st }}$. On May $8^{\text {th }}$, the number of $C$. napi larvae was determined on fullflowering plants (BBCH growth stage 64-67) by random sampling of ten plants per genotype and plot. Larvae were dissected from the main stems under a stereo microscope (Zeiss, Stemi 2000-C). At the same time, the basal stem diameter, the length of the main stem and the length of the feeding tunnels by larvae within the main stem were measured. The stem injury coefficient was calculated by relating the length of larval feeding tunnel within the stem to the 
length of the full-grown main stem (Ferguson et al. 2003). The larval instars of $C$. napi were classified based on the head capsule width (Guenthart 1949). The larval instar index was calculated by the subtraction of the number of $3^{\text {rd }}$ instar larvae by the number of $2^{\text {nd }}$ instar larvae and the summation of the constant $\mathrm{K}(\mathrm{K}=2$, to avoid negative values) according to Kurtz et al. (2010). The larval dry body mass of ten larvae per larval instar and plot was determined by drying the larvae at $60{ }^{\circ} \mathrm{C}$ for three days, and weighing individual larvae (Sartorius micro scale, MC5).

Table 1 Origin of twelve genotypes of Brassica napus evaluated in the semi-field experiment in 2011/2012, according to Girke (2002) and Rudloff (unpubl. MSc thesis, Goettingen 2013). ++ = high content of erucic acid and glucosinolates in seeds; $(00)=$ no erucic acid and low glucosinolate content in seeds; ${ }^{\text {a }}=$ winter mortality

\begin{tabular}{|c|c|c|}
\hline Genotype & Type & Species \\
\hline Campala & (00) cultivar & B. napus var. biennis \\
\hline Goe1991 & (00) line & B. napus var. biennis \\
\hline DH Samourai $^{\mathrm{a}}$ & (00) DH-line & B. napus var. biennis \\
\hline Olimpiade $^{\mathrm{a}}$ & $(++)$ cultivar & B. napus var. biennis \\
\hline Express617 & (00) cultivar & B. napus var. biennis \\
\hline Visby & (00) hybrid cultivar & B. napus var. biennis \\
\hline G53 & resynthesized line & $\begin{array}{l}\text { B. oleracea convar. capitata var. capitata } \mathrm{X} \\
\text { B. rapa ssp. nipposinica var. perviridis }\end{array}$ \\
\hline $\mathrm{R} 53^{\mathrm{a}}$ & resynthesized line & $\begin{array}{l}\text { B. oleracea convar. acephala var. sabellica X } \\
\text { B. rapa ssp. pekinensis }\end{array}$ \\
\hline S3 & resynthesized line & $\begin{array}{l}\text { B. rapa ssp. rapa X } \\
\text { B. oleracea convar. acephala var. sabellica }\end{array}$ \\
\hline L122 & resynthesized line & $\begin{array}{l}\text { B. oleracea convar. capitata var. sabauda X } \\
\text { B. rapa ssp. pekinensis }\end{array}$ \\
\hline S30 & resynthesized line & $\begin{array}{l}\text { B. oleracea convar. capitata var. capitata X } \\
\text { B. rapa ssp. pekinensis }\end{array}$ \\
\hline L16 & resynthesized line & $\begin{array}{l}\text { B. oleracea convar. botrytis var. alboglabra X } \\
\text { B. rapa ssp. pekinensis }\end{array}$ \\
\hline
\end{tabular}

Chemical analysis: Only five non-infested stems of six genotypes (Campala, Express617, Visby, L16, S3, S30) were sampled for glucosinolate analyses on March $23^{\text {rd }}$ just before the release of $C$. napi, because of high winter mortality. The stems were frozen on dry ice and stored at $-20{ }^{\circ} \mathrm{C}$. Each sample was freeze-dried for 96 hours and homogenized by using a mill (Krups KM 75). Stem glucosinolates were separated and individual compounds identified and quantified (Thies 1977). Desulfoglucosinolates were extracted as detailed in 
Cleemput and Becker (2012). Glucosinolates were analyzed by high-performance liquid chromatography by using a Shimadzu Prominence LC20AT series instrument (Shimadzu Deutschland GmbH) equipped with a Nucleodur 100-3 C18 column (Macherey Nagel). Desulfoglucosinolates were separated using a water-acetonitrile gradient (solvent A water, solvent B acetonitrile; 0-20 min 1-20\% B; 20-25 min 20\% B; 25-27 min $20 \%$ B; 27-34 min $1 \% \mathrm{~B}$ ) at a flow rate of $0.6 \mathrm{ml} / \mathrm{min}$. Retention times of known standards were used to identify desulfoglucosinolates. Glucosinolate contents are expressed in $\mu \mathrm{mol} / \mathrm{g}$ dry weight (D.W.).

Table 2 Names of individual glucosinolates and chemical groups of glucosinolates detected in stems of Brassica napus genotypes according to Velasco and Becker (2000), Fahey et al. (2001), Halkier and Gershenzon (2006) and Feng et al. (2012)

\begin{tabular}{llll}
\hline Systematic name & Trivial name & Abbreviation & Group \\
\hline 2-hydroxy-3-butenyl & progoitrin & PRO & aliphatic \\
2-hydroxy-4-pentenyl & napoleiferin & GNL & aliphatic \\
5-methylsulphinylpentyl & glucoalyssin & ALY & aliphatic \\
3-butenyl & gluconapin & GNA & aliphatic \\
4-pentenyl & glucobrassicanapin & GBN & aliphatic \\
4-hydroxy-3-indolylmethyl & 4-hydroxyglucobrassicin & 4OH & indolyl \\
3-indolylmethyl & glucobrassicin & GBC & indolyl \\
4-methoxy-3-indolylmethyl & 4-methoxyglucobrassicin & 4ME & indolyl \\
n-methoxy-3-indolylmethyl & neoglucobrassicin & NEO & indolyl \\
\hline
\end{tabular}

\section{Data Analysis}

Univariate data analysis: Univariate data analysis was performed by using Statistica 10 (StatSoft $^{\circledR}$, Tulsa, USA) and tested for normal distribution using Shapiro-Wilk $W$ Test. Factorial one-way analysis of variance (ANOVA) was performed to analyze differences between plant densities as well as between the length of the full-grown stems (values were $\log \left(x^{+1}\right)$ transformed), basal stem diameters and stem injury coefficients of tested genotypes. Factorial one-way Kruskal-Wallis variance analysis (KW-ANOVA) was used to analyze genotype effects on the length of stems at the beginning of the oviposition period of $C$. napi and on larval feeding tunnels, larval instar indices and dry body masses of larval instars.

The effect of the genotype on the number of larvae was tested by analysis of covariance (ANCOVA). The number of larvae was treated as the main factor and the length of full-grown stem and the basal stem diameter were included as covariates. The length of the 
stem at the beginning of the oviposition period and the plant density were not included into the model, because of multi-collinearity with the covariate length of full-grown stem.

The relationship between the number of larvae and the glucosinolate groups, the aliphatic/indolyl ratios and the total glucosinolate contents of stems of the non-infested genotypes was analyzed by using a linear regression. The relationship between the stem injury coefficients and the glucosinolate groups, the aliphatic/indolyl ratios and the total glucosinolate contents of stems of the non-infested genotypes was not statistically analysed, because of multi-collinearity of stem injury coefficients and the number of larvae in main stems. The relationship between the stem injury coefficients and the larval instar indices of $C$. napi was not statistically analysed, because of multi-collinearity of both stem injury coefficients and larval instar indices with the number of larvae in main stems.

To analyze the relationship between number of larvae and plant densities, length of stems at the beginning of the oviposition period, basal stem diameters and the stem injury coefficients a linear regression was performed for each relationship. The same model was used to analyze the relationship between larval instar indices and basal stem diameters. Pearson Product Moment Correlation was used to evaluate the correlation between the number of larvae and the larval instar index.

Multivariate data analysis: Multivariate data analysis was performed with R 3.0.1. Partial Least Squares - Discriminant Analysis (PLS-DA; Barker and Rayens 2003) was performed on the normalized concentrations to discriminate genotypes based on their glucosinolate profiles (function 'plsda', package 'mixOmics'). The significance of the discrimination was tested by performing a multivariate ANOVA (MANOVA). MANOVA was also used to compare glucosinolate profiles of genotypes (response variable) with glucosinolate profiles of genotypes S30, L16 and Campala (references). Glucosinolate profiles of S30 and Campala were used as a reference, because of a low infestation and L16 because of a high infestation by $C$. napi larvae.

Partial Least Squares Regression (PLSR; Geladi and Kowalski 1986) was applied to investigate the relationship between the glucosinolate profile of non-infested stems and the number of $C$. napi larvae in the main stems (function 'pls' regression mode, package 'mixOmics'). Data was scaled to unit variance and means centered by default in the analysis. PLSR was not applied to analyze the relationship between the stem injury coefficients and the glucosinolate profile of stems, because of multi-collinearity of stem injury coefficients and the number of larvae in main stems. For the same reason no PLSR was performed to analyze the relationship between the glucosinolate profile of stems and larval instar indices. 


\section{Results}

Plant traits and larval infestation of C. napi: At the beginning of the oviposition period of $C$. napi most of the tested genotypes were at BBCH growth stage 52, except for cultivar Express617 and resynthesized line S30, which were at BBCH growth stage 55, and cultivar Visby and resynthesized line S3, which were at BBCH growth stage 57 (Table 3). The plant density significantly differed between genotypes $\left(F_{8,45}=13.087, P=0.000\right)$. Mean plant density was lowest in L122 and highest in resynthesized lines S3 and L16 and in cultivar Visby (Table 3). The length of the stem at the beginning of the oviposition period significantly differed between genotypes $(H(8, N=50)=26.362, P=0.001)$. The resynthesized lines G53, L122 and L16 showed a significantly shorter stem length at the beginning of the oviposition period compared to cultivar Visby (Table 3). The length of the full-grown stem also significantly differed between genotypes $\left(F_{8,45}=8.857, P=0.000\right)$. The cultivar Visby showed a significantly longer stem compared to cultivar Campala, line Goe1991, and resynthesized lines L122, G53 and S30 (Table 3). The basal stem diameter of full-grown stems significantly differed among genotypes $\left(F_{8,45}=4.567, P=0.000\right)$. Mean basal stem diameter of Visby was the highest (Table 3). The number of $C$. napi larvae was not dependent upon the plant density ( $R=0.371, F=1.116, P=0.326$ ), neither upon length of the stems at the beginning of the oviposition period $(R=0.018, F=0.002, P=0.964)$ nor upon the basal stem diameter $(R=0.339, F=0.911, P=0.372)$.

Table 3 Plant traits of nine Brassica napus genotypes evaluated in the semi-field experiment in 2011/2012. Mean values $( \pm \mathrm{SE})$ of five to six replicates. BBCH growth stages on March $31^{\text {st }}$, plant densities on March $23^{\text {rd }}$, basal stem diameters and length of full-grown stems on May $8^{\text {th }}$, Tukey-Test, $P \leq 0.05$. Length of stems at the beginning of the oviposition period on March $31^{\text {st }}$, Kruskal-Wallis Test, $P \leq 0.05$. Different letters within each column indicate significant differences between genotypes.

\begin{tabular}{llllll}
\hline Genotype & BBCH & $\begin{array}{l}\text { Plant density } \\
\text { (plants / m) }\end{array}$ & $\begin{array}{l}\text { Length of stem at } \\
\text { beginning of oviposition } \\
\text { period }(\mathrm{cm})\end{array}$ & $\begin{array}{l}\text { Length of full- } \\
\text { grown stem }(\mathrm{cm})\end{array}$ & $\begin{array}{l}\text { Basal diameter of } \\
\text { full-grown stem } \\
\text { (cm) }\end{array}$ \\
\hline S30 & 55 & $6.25 \pm 0.423 \mathrm{~b}$ & $23.74 \pm 3.694 \mathrm{ab}$ & $63.60 \pm 3.641 \mathrm{bcd}$ & $0.95 \pm 0.085 \mathrm{bc}$ \\
G53 & 52 & $6.25 \pm 0.574 \mathrm{~b}$ & $15.00 \pm 3.260 \mathrm{~b}$ & $58.74 \pm 5.729 \mathrm{~cd}$ & $0.77 \pm 0.106 \mathrm{bc}$ \\
S3 & 57 & $9.50 \pm 0.658 \mathrm{a}$ & $30.42 \pm 3.948 \mathrm{ab}$ & $89.80 \pm 7.056 \mathrm{ab}$ & $0.96 \pm 0.034 \mathrm{bc}$ \\
L122 & 52 & $3.33 \pm 0.891 \mathrm{c}$ & $13.50 \pm 3.122 \mathrm{~b}$ & $52.38 \pm 4.845 \mathrm{~d}$ & $1.05 \pm 0.086 \mathrm{abc}$ \\
L16 & 52 & $9.83 \pm 0.760 \mathrm{a}$ & $16.67 \pm 1.787 \mathrm{~b}$ & $81.55 \pm 6.141 \mathrm{abc}$ & $1.07 \pm 0.074 \mathrm{abc}$ \\
Campala & 52 & $6.08 \pm 0.396 \mathrm{ab}$ & $17.08 \pm 1.981 \mathrm{ab}$ & $48.82 \pm 4.959 \mathrm{~d}$ & $1.12 \pm 0.102 \mathrm{abc}$ \\
Goe1991 & 52 & $6.17 \pm 0.667 \mathrm{~b}$ & $16.88 \pm 0.884 \mathrm{ab}$ & $63.58 \pm 7.433 \mathrm{bcd}$ & $0.89 \pm 0.104 \mathrm{bc}$ \\
Express617 & 55 & $8.25 \pm 0.382 \mathrm{ab}$ & $19.58 \pm 2.770 \mathrm{ab}$ & $77.88 \pm 6.044 \mathrm{abc}$ & $1.25 \pm 0.089 \mathrm{ab}$ \\
Visby & 57 & $9.75 \pm 0.528 \mathrm{a}$ & $37.92 \pm 1.502 \mathrm{a}$ & $97.60 \pm 3.481 \mathrm{a}$ & $1.39 \pm 0.087 \mathrm{a}$ \\
\hline
\end{tabular}


The mean number of $C$. napi larvae ranged from 1.49 larvae per main stem (S30) to 7.23 larvae per main stem (L16) (Fig. 1). The number of larvae per main stem significantly differed between individual genotypes $\left(F_{8,43}=7.148, P=0.000\right)$ (Table 4 and Fig. 1$)$. The resynthesized line S30 and the cultivar Campala contained significantly less larvae compared to the resynthesized lines L122 and L16 (Fig. 1). The number of larvae was significantly affected by the length of the full-grown stems and the basal stem diameters (Table 4).

Table 4 Effect of genotype and covariates on the number of Ceutorhynchus napi larvae. Analysis of covariance, $P \leq 0.05$. Nine genotypes, six replicates, sample size $(N)$, degree of freedom $(D F)$, and $F$-value

\begin{tabular}{lllll}
\hline & $N$ & $D F$ & $F$ & $P$ \\
\hline Factor: Genotype & 54 & 8 & 7.148 & 0.000 \\
Covariates: & & & & \\
$\quad$ Basal diameter of full-grown stem & 54 & 1 & 12.382 & 0.001 \\
$\quad$ Length of full-grown stem & 54 & 1 & 8.377 & 0.006 \\
\hline
\end{tabular}

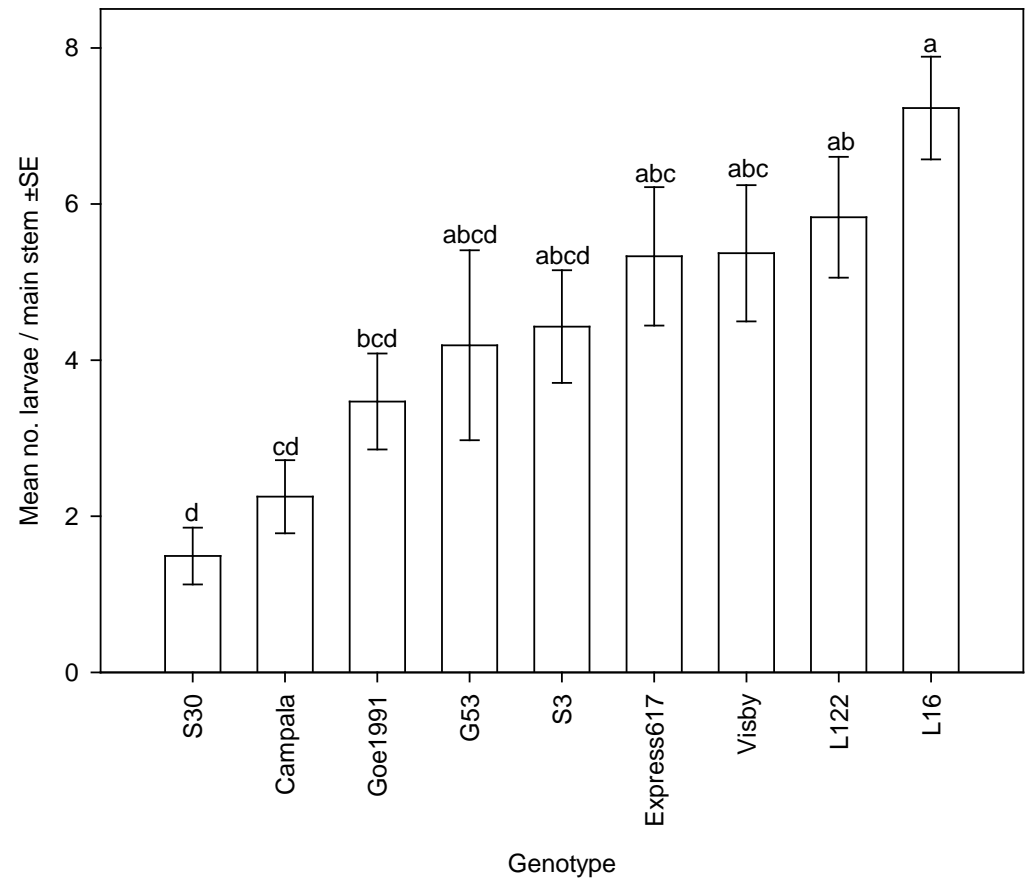

Fig. 1 Number of Ceutorhynchus napi larvae in main stems of nine Brassica napus genotypes on May $8^{\text {th }}$. Mean values $( \pm \mathrm{SE})$ of six replicates. Different letters indicate significant differences between the number of larvae in individual genotypes, Tukey-Test, $P \leq 0.05$ 
Stem glucosinolates: The PLS-DA analysis and the associated MANOVA revealed that the glucosinolate profiles of non-infested stems significantly differed between individual genotypes. The factorial map explained $81.71 \%$ of the intergenotypic variance (Fig. 2).

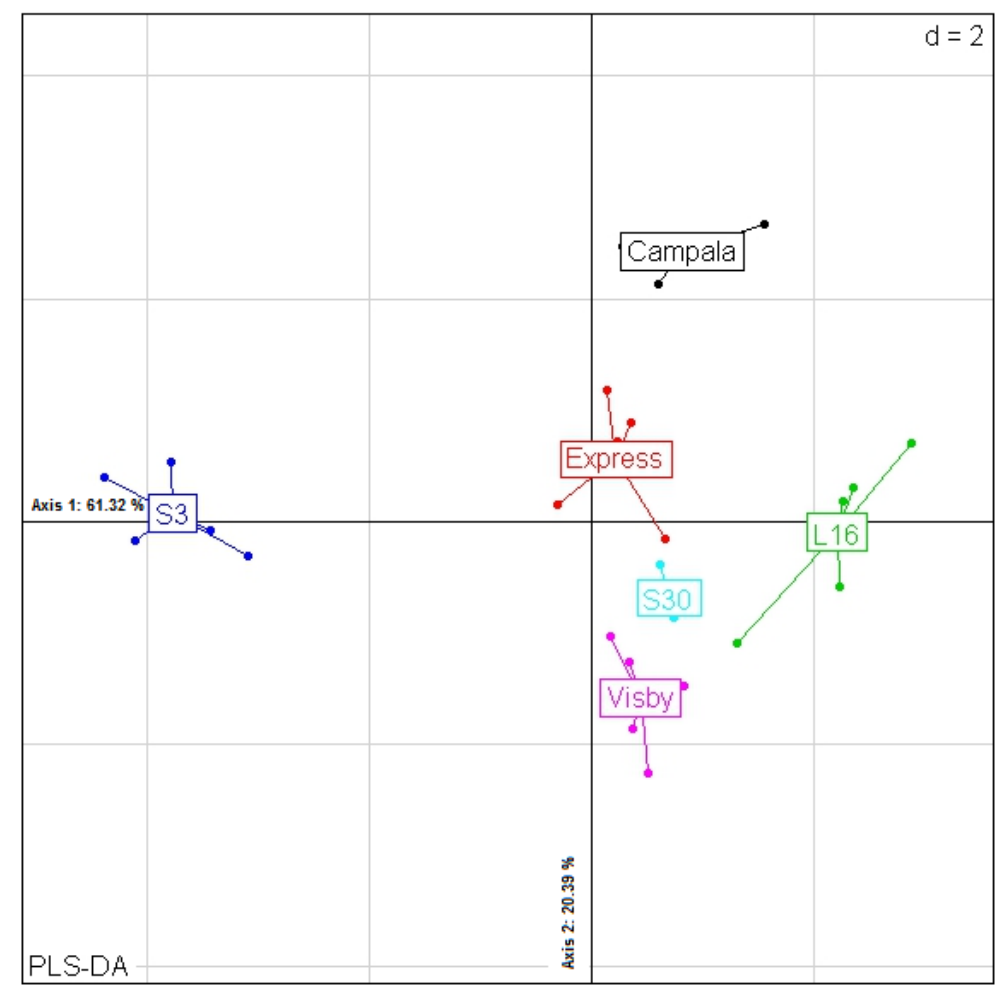

Fig. 2 Score plot of the Partial Least Squares - Discriminant Analysis. PLS-DA analysis performed on the glucosinolate profile of non-infested stems of six Brassica napus genotypes on April $17^{\text {th }}$ (score plot explained $81.71 \%$ of the intergenotypic variance; results of the MANOVA testing for the discrimination of genotypes: pseudo- $\left.F_{45,80}=3.124, P \leq 0.05\right)$

Reference glucosinolate profile (S30): The MANOVA showed that the content of PRO in S30 significantly differed from L16 $(P=0.010)$ and S3 $(P=0.000)$. The content of GBN in S30 significantly differed from L16 $(P=0.000)$, Express617 $(P=0.002)$, Campala $(P$ $=0.003)$ and S3 $(P=0.040)$. The content of GBC in S30 significantly differed from Campala $(P=0.024)$. The content of NEO in S30 significantly differed from Camapla $(P=0.004)$, Express617 $(P=0.004)$, L16 $(P=0.005)$ and S3 $(P=0.016)$ (Fig. 2 and Table 5).

Reference glucosinolate profile (Campala): The MANOVA showed that the content of PRO in Campala significantly differed from L16 $(P=0.011)$ and S3 $(P=0.001)$. The content of GNA in Campala significantly differed from Visby $(P=0.004)$, S3 $(P=0.000)$, L16 $(P=$ 0.001) and S30 $(P=0.007)$. The content of GBN in Campala significantly differed from Visby $(P=0.002)$, L16 $(P=0.000)$, Express617 $(P=0.004)$ and S30 $(P=0.015)$. The content of GBC in Campala significantly differed from Visby $(P=0.001)$, S3 $(P=0.000)$, 
Express617 $(P=0.007)$ and S30 $(P=0.024)$. The content of NEO in Campala significantly differed from Visby $(P=0.001)$, S3 $(P=0.000)$, L16 $(P=0.000)$, Express617 $(P=0.000)$ and S30 $(P=0.004)$ (Fig. 2 and Table 5).

Reference glucosinolate profile (L16): The MANOVA showed that the content of 4OH in L16 significantly differed from Visby $(P=0.002)$, S3 $(P=0.005)$, Express617 $(P=$ 0.008), Campala $(P=0.028)$ and S30 $(P=0.017)$. The content of GBC in L16 significantly differed from S3 $(P=0.000)$, Visby $(P=0.001)$ and Express617 $(P=0.017)$. The content of NEO in L16 significantly differed from Campala $(P=0.000)$, S3 $(P=0.004)$, S30 $(P=0.005)$ and from Visby $(P=0.022)$ (Fig. 2 and Table 5).

In the non-infested stems of Campala the content of GBN, GBC and NEO was higher than in all other test genotypes (Table 5). L16 showed the highest content of $4 \mathrm{OH}$, the lowest total glucosinolate content, the lowest aliphatic glucosinolate content and the lowest aliphatic/indolyl ratio (Table 5 and Table 6). S3 showed the highest content of PRO, the highest total glucosinolate content, the highest aliphatic content, the lowest indolyl content and the highest aliphatic/indolyl ratio (Table 5 and Table 6).

Table 5 Glucosinolate contents of non-infested stems ( $\mu$ mol / g D.W.) on March $23^{\text {rd }}$ in six Brassica napus genotypes grown in the semi-field experiment in 2011/2012. Values are means of four to six replicates. See Table 2 for abbreviations, systematic and trivial names of individual glucosinolates

\begin{tabular}{lrllrlllll}
\hline Genotype & \multicolumn{1}{c}{ PRO } & GNL & ALY & GNA & GBN & 4OH & GBC & 4ME & NEO \\
\hline Campala & 6.71 & 0.00 & 1.38 & 1.67 & 9.51 & 0.02 & 3.25 & 0.26 & 4.05 \\
Express617 & 7.56 & 0.03 & 1.68 & 1.10 & 7.05 & 0.01 & 1.57 & 0.24 & 2.52 \\
Visby & 5.45 & 0.00 & 1.89 & 0.52 & 3.23 & 0.00 & 0.98 & 0.10 & 0.61 \\
L16 & 1.33 & 0.00 & 0.39 & 0.29 & 0.78 & 0.06 & 2.82 & 0.08 & 2.48 \\
S3 & 25.16 & 0.35 & 0.94 & 10.39 & 8.20 & 0.01 & 0.78 & 0.31 & 0.36 \\
S30 & 6.79 & 0.00 & 1.33 & 0.49 & 4.40 & 0.01 & 1.73 & 0.09 & 1.32 \\
\hline
\end{tabular}

Table 6 Total contents of glucosinolates (GSL), aliphatic and indolyl glucosinolates ( $\mu m o l$ / g D.W.) and ratio between aliphatic and indolyl glucosinolates of non-infested stems on March $23^{\text {rd }}$ in six Brassica napus genotypes grown in the semi-field experiment in 2011/2012. Values are means of four to six replicates. See Table 2 for classification of groups of glucosinolates

\begin{tabular}{lllll}
\hline Genotype & Total GSL & Aliphatic & Indolyl & Aliphatic/Indolyl \\
\hline Campala & 26.85 & 19.27 & 7.58 & 2.54 \\
Express617 & 21.76 & 17.42 & 4.34 & 4.01 \\
Visby & 12.78 & 11.09 & 1.69 & 6.56 \\
L16 & 8.23 & 2.79 & 5.44 & 0.51 \\
S3 & 46.50 & 45.04 & 1.46 & 30.85 \\
S30 & 16.16 & 13.01 & 3.15 & 4.13 \\
\hline
\end{tabular}


The PLSR analysis identified no relationship between the number of $C$. napi larvae in main stems and the glucosinolate profile of non-infested stems. The factorial map 1-2 only explained $18.11 \%$ variance of the number of larvae and the short arrow ( $\leq$ radius) of the larvae was found to be unrepresentative in the PLSR analysis (Fig. 3).

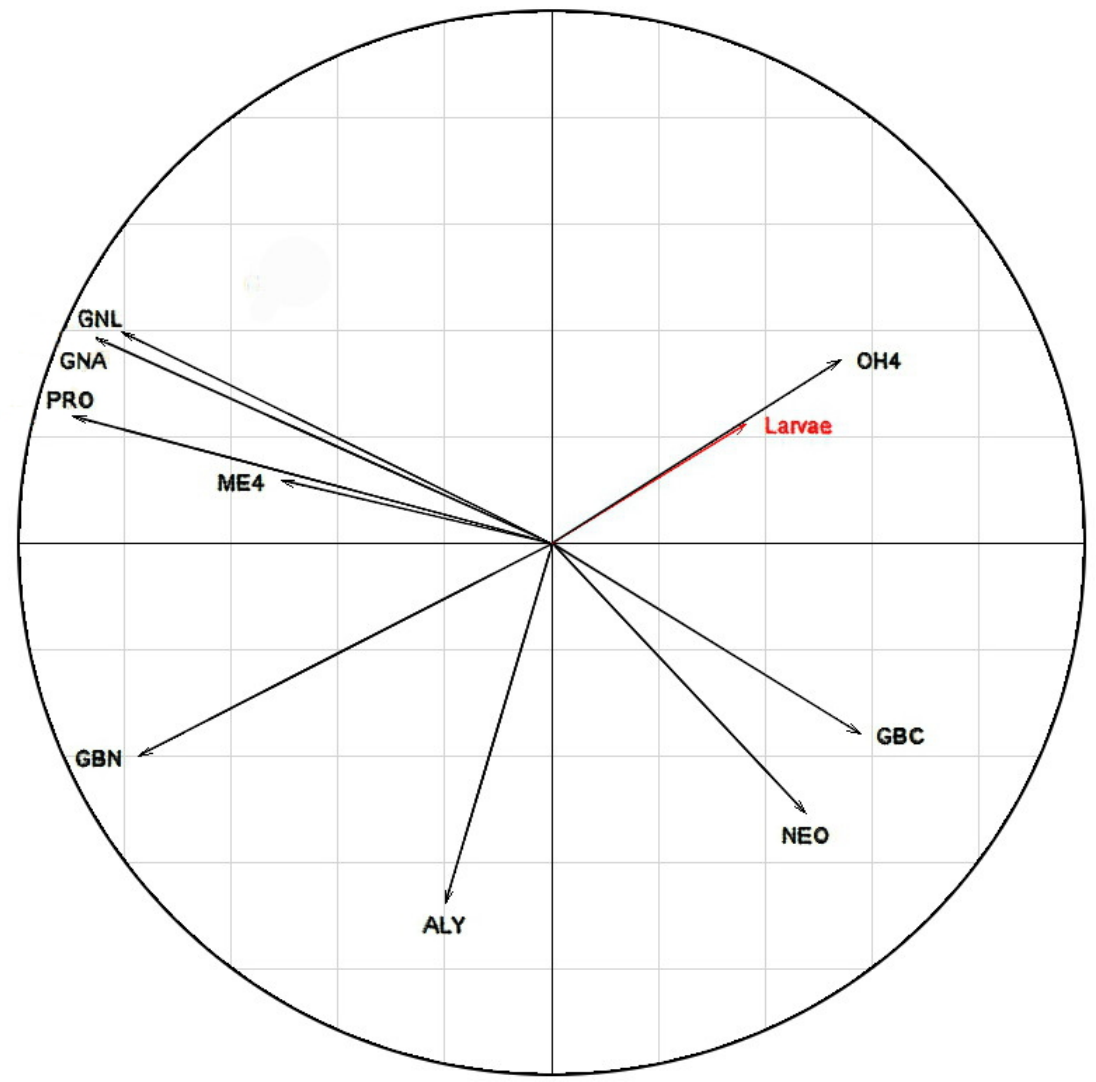

Fig. 3 Loading Plot of the Partial Least Squares Regression analysis indicating the relationship between the number of Ceutorhynchus napi larvae in main stems and the glucosinolate profile of non-infested stems of six Brassica napus genotypes grown in the semi-field experiment in 2011/2012. The factorial map 1-2 explained $18.11 \%$ variance of the number of larvae. See Table 2 for abbreviations, systematic and trivial names of individual glucosinolates

Concerning individual contents of glucosinolate groups and total glucosinolate content of non-infested stems of genotypes, no correlation between number of $C$. napi larvae in main stems and total glucosinolate content, content of aliphatic group, content of indolyl group and aliphatic/indolyl ratio was found (Table 7). 
Table 7 Relationship between the number of Ceutorhynchus napi larvae in main stems and contents of total, aliphatic, indolyl glucosinolates and aliphatic/indolyl ratio of non-infested stems of six Brassica napus genotypes grown in the semi-field experiment in 2011/2012. Linear regression, $P \leq 0.05$. See Table 2 for classification of groups of glucosinolates

\begin{tabular}{llll}
\hline Glucosinolates & \multicolumn{3}{c}{ No. larvae / stem } \\
& $R$ & $F$ & $P$ \\
\hline Total & 0.279 & 0.339 & 0.592 \\
Aliphatic & 0.244 & 0.254 & 0.641 \\
Indolyl & 0.126 & 0.065 & 0.812 \\
Aliphatic/Indolyl & 0.021 & 0.002 & 0.968 \\
\hline
\end{tabular}

Larval performance of C. napi: The length of the feeding tunnels caused by $C$. napi larvae significantly differed between individual genotypes $(H(8, N=54)=27.058, P=$ 0.001). The mean length of feeding tunnels was significantly shorter in the resynthesized line S30 than in resynthesized line L16 and cultivar Visby (Table 8). The stem injury coefficient significantly differed between individual genotypes $\left(F_{8,45}=6.257, P=0.000\right)$. The resynthesized line S30 showed the lowest stem injury coefficient among all tested genotypes (Table 8). The dry body mass of $2^{\text {nd }}$ and $3^{\text {rd }}$ instar larvae of $C$. napi varied widely, but was not significantly affected by the genotype $(H(8, N=42)=8.361, P=0.399) ;(H(8, N=51)=$ 10.243, $P=0.248$ ), respectively (Table 8).

Table 8 Genotypes grown in the semi-field experiment in 2011/2012. Mean values ( \pm SE) of three to six replicates. Length of the feeding tunnels within main stems of full-grown plants on May $8^{\text {th }}$, Kruskal-Wallis Test, $P \leq 0.05$; Stem injury coefficient on May $8^{\text {th }}$, Tukey-Test, $P \leq 0.05$. Different letters within each column indicate significant differences between genotypes

\begin{tabular}{lllll}
\hline Genotype & $\begin{array}{l}\text { Length of feeding } \\
\text { tunnel }(\mathrm{cm})\end{array}$ & $\begin{array}{l}\text { Stem injury } \\
\text { coefficient }\end{array}$ & $\begin{array}{l}\text { Dry body mass of } \\
2^{\text {nd }} \text { larval instar } \\
(\mathrm{mg})\end{array}$ & $\begin{array}{l}\text { Dry body mass of } \\
3^{\text {rd }} \text { larval instar } \\
(\mathrm{mg})\end{array}$ \\
\hline G53 & $26.69 \pm 5.25 \mathrm{ab}$ & $0.43 \pm 0.10 \mathrm{ab}$ & $0.17 \pm 0.01$ & $1.52 \pm 0.50$ \\
L122 & $27.21 \pm 2.78 \mathrm{ab}$ & $0.52 \pm 0.02 \mathrm{a}$ & $0.24 \pm 0.03$ & $1.11 \pm 0.19$ \\
Express617 & $29.25 \pm 2.10 \mathrm{ab}$ & $0.38 \pm 0.04 \mathrm{ab}$ & $0.19 \pm 0.04$ & $1.28 \pm 0.34$ \\
S30 & $13.09 \pm 1.77 \mathrm{~b}$ & $0.20 \pm 0.03 \mathrm{c}$ & $0.21 \pm 0.02$ & $1.31 \pm 0.45$ \\
L16 & $34.45 \pm 2.55 \mathrm{a}$ & $0.43 \pm 0.03 \mathrm{ab}$ & $0.32 \pm 0.11$ & $1.87 \pm 0.35$ \\
Campala & $16.82 \pm 2.12 \mathrm{ab}$ & $0.34 \pm 0.02 \mathrm{bc}$ & $0.19 \pm 0.02$ & $1.19 \pm 0.24$ \\
S3 & $29.73 \pm 2.68 \mathrm{ab}$ & $0.35 \pm 0.05 \mathrm{bc}$ & $0.20 \pm 0.01$ & $1.79 \pm 0.33$ \\
Goe1991 & $22.25 \pm 3.35 \mathrm{ab}$ & $0.34 \pm 0.02 \mathrm{bc}$ & $0.20 \pm 0.03$ & $0.83 \pm 0.20$ \\
Visby & $34.73 \pm 4.10 \mathrm{a}$ & $0.36 \pm 0.04 \mathrm{bc}$ & $0.33 \pm 0.08$ & $1.53 \pm 0.26$ \\
\hline
\end{tabular}


Chapter II

The number of $C$. napi larvae in the main stems was significantly positive dependent upon stem injury coefficients (Fig. 4).

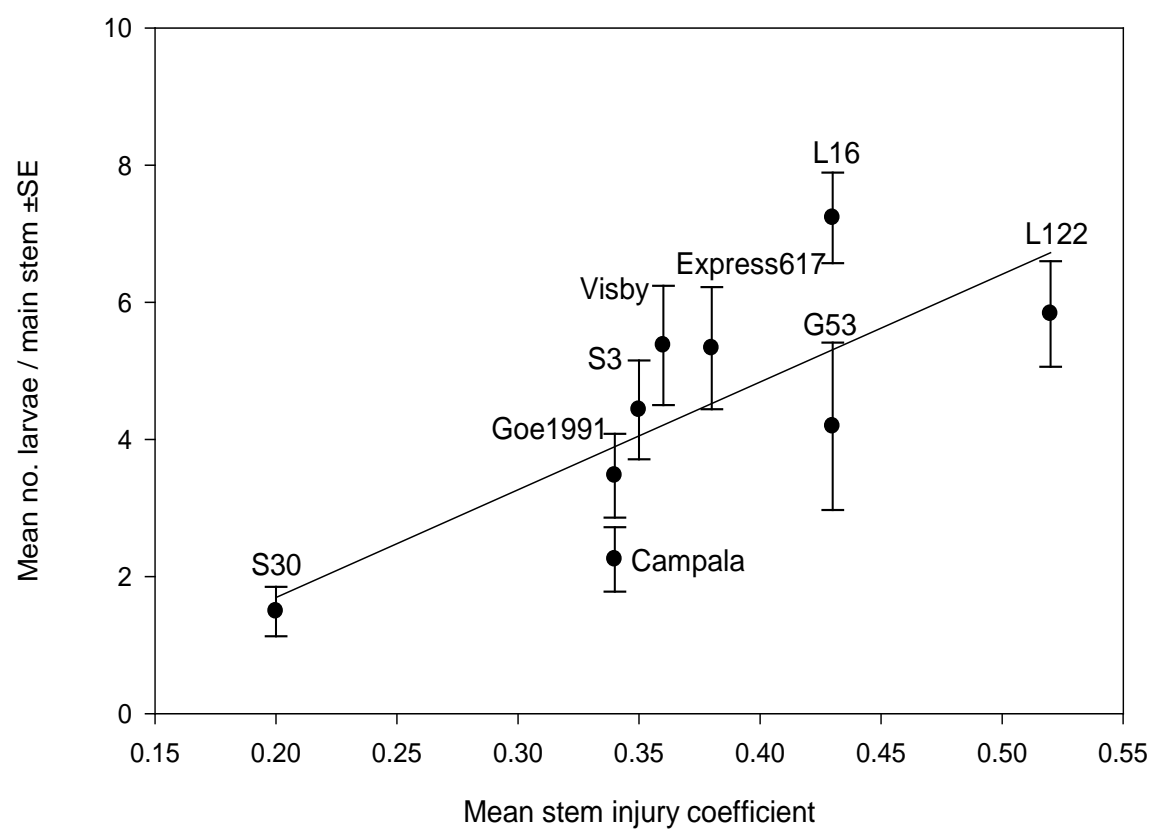

Fig. 4 Relationship between the number of Ceutorhynchus napi larvae in main stems and stem injury coefficients of nine Brassica napus genotypes on May $8^{\text {th }}$ grown in the semi-field experiment in 2011/2012; Liner Regression Model: $(\mathrm{y}=-1.450+15.713 \mathrm{x}, R=0.763, F=9.747, P=0.017)$

The mean larval instar index of C. napi ranged from 1.85 (S30) to 6.67 (L16). The larval instar index significantly differed between genotypes $(H(8, N=52)=29.861, P=$ 0.000). The larval development in the resynthesized lines S30 and L122, in the cultivar Campala and in the line Goe1991 was significantly delayed compared to the resynthesized line L16 (Fig. 5). The number of larvae was significantly positive correlated with the instar index $(R=0.731, N=52, P=0.025)$. The larval instar index was not dependent upon the basal stem diameter $(R=0.190, F=0.263, P=0.624)$. 


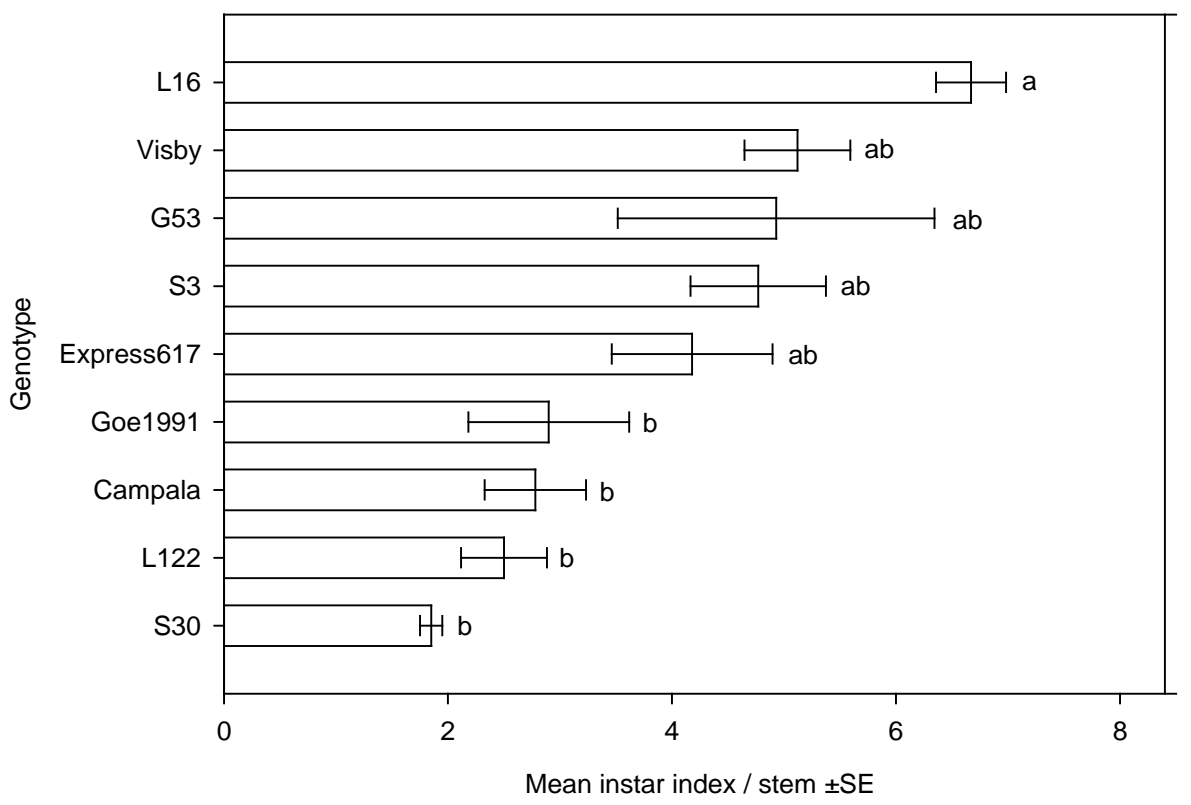

Fig. 5 Larval instar indices of Ceutorhynchus napi developed in main stems of nine Brassica napus genotypes until May $8^{\text {th }}$. Genotypes were grown in the semi-field experiment in 2011/2012. Values are means $( \pm$ SE) of five to six replicates. Different letters indicate significant differences between larval instar indices, KruskalWallis Test, $P \leq 0.05$

\section{Discussion}

The results of the present semi-field experiment showed considerable variation in infestation levels by $C$. napi between different lines, cultivars and resynthesized lines of oilseed rape. In the resynthesized line S30, the number of larvae per main stem was significantly lower than in the resynthesized lines L16 and L122 and cultivars Visby and Express617. Similar studies obtained in the open field also indicated a low number of larvae in S30 (chapter III and IV). In the present study, the line Goe1991 and the cultivar Campala also contained a low number of $C$. napi larvae, but in a similar study obtained in the open field (chapter IV and appendix ), Goe1991 and Campala did not contain a low number of $C$. napi larvae.

Resynthesized lines of oilseed rape might provide valuable sources of resistance to insect pests of oilseed rape (Seyis et al. 2001; Eickermann 2011). The low number of C. napi larvae in S30 may result from a low oviposition by C. napi or by an increased egg and larval mortality. Low numbers of eggs deposited by C. napi indicated antixenosis resistance, while increased egg and larval mortality indicated antibiosis resistance. Abundance of eggs could not be assessed in this study. Additionally, the results presented in chapter III indicated no 
differences in egg and larval mortality between individual genotypes. Antixenosis is the insects' avoidance or non-preference of plants during the search for oviposition sites, while antibiosis affects the performance of herbivores such as reduced weight or increased mortality (Sarfraz et al. 2006).

Different host plant densities might affect insect pests in oilseed rape (Nuss 2004). In this study the resynthesized line L16, which had the highest number of $C$. napi larvae in the main stems, also had the highest plant density. The resynthesized line L122, which also had a high number of $C$. napi larvae, had the lowest plant density among all tested genotypes. But no relationship between the number of $C$. napi larvae and the plant density was found in the present study. Nuss (2004) found that the number of eggs deposited by $C$. napi and $C$. pallidactylus into the plant tissue was negatively correlated with the plant density of oilseed rape. Nuss (2004) also found that the abundance of cabbage stem flea beetle larvae (Psylliodes chrysocephala (L.)) was inversely correlated with the plant density of oilseed rape. Experiments on canola revealed that an increased plant density can reduce infestation by maggots of Delia spp. (Dosdall et al. 1996).

A non-metabolic factor affecting the host plant selection of insects is plant morphology (Sarfraz et al. 2006). Growth stages of the genotypes at the beginning of the oviposition period of $C$. napi did not appear to affect C. napi infestation. Even though S30, as well as Express617, Visby and S3 had an enhanced growth stage at the beginning of the oviposition period of $C$. napi, S30 did not contain a high number of $C$. napi larvae.

A further morphological plant trait which might affected host acceptance of $C$. napi is the length of the oilseed rape plant. Buechi (1996) found that plants longer than $22 \mathrm{~cm}$ were less preferred for egg-laying by females of $C$. napi than shorter plants. In this study, the number of larvae was not dependent upon length of the stems at the beginning of the oviposition period of $C$. napi.

Oviposition by C. napi takes place during stem elongation growth (Lerin 1993). The process of egg deposition may result in considerable disruption to stem growth (Alford et al. 2003). Additionally, the C. napi larvae feed within the pith tissue of the stem (Paul 2003). The length of the full-grown stem of the genotypes has been evaluated to determine effects of oviposition and larval infestation of $C$. napi on the plant growth rate. Visby, which showed a high number of $C$. napi larvae, also showed the longest full-grown stem, while L122, which also showed a high number of $C$. napi larvae, showed the shortest full-grown stem. The resynthesized line S30 and the cultivar Campala, which contained a low number of C. napi larvae, also showed shorter full-grown stems than Visby. We presume that Visby can better 
compensate for high levels of $C$. napi infestation by a high stem elongation growth compared to S30 and Campala. However, the length of full-grown stems was not assessed from noninfested control plants. Additionally, plant growth rate can be also affected by environmental factors (McNaughton 1983).

Metabolic plant compounds such as glucosinolates can affect host acceptance and performance of herbivorous insects (Mayer 2004; Schoonhoven et al. 2005). Glucosinolates are the major group of secondary metabolites in the Brassicaceae (Rodman et al. 1996) and might trigger oviposition by crucifer-feeding insects (Renwick et al. 1992; Van Loon et al. 1992; Chew and Renwick 1995). They are catalyzed by the endogenous enzyme myrosinase following disruption (Fenwick and Heaney 1983; Hopkins et al. 2009), while myrosinase is spatially separated from glucosinolates in non-disrupted cells (Mithen 1992, 2001).

Glucosinolates can also cause repulsion or deterrence of specialist insect pests in crucifer plants (Waligora and Krzymanska 1995). Therefore, we have analyzed glucosinolate contents of non-infested stems of genotypes to determine the effect of glucosinolates on oviposition and larval infestation by C. napi. The PLS-DA and the associated MANOVA revealed that the glucosinolate profiles of non-infested stems differed between the genotypes. By comparing individual glucosinolate contents of the highly infested resynthesized line L16 with the lowly infested resynthesized line S30 and cultivar Campala, it was observed that the content of $4 \mathrm{OH}$ was highest in L16 and the content of GBN lowest in L16. However, in the present study the PLSR indicated no relationship between the number of $C$. napi larvae and the glucosinolate profile of non-infested stems. Another study found that the level of infestation by adult pollen beetle (Meligethes aeneus (F.)) correlated positively with the $4 \mathrm{OH}$ content of the buds of different B. napus genotypes (Meier, unpubl. MSc thesis, Goettingen 2013). Hennies (unpubl. MSc thesis, Goettingen 2012) also found a positive correlation between larval infestation by $P$. chrysocephala and the $4 \mathrm{OH}$ content of petioles of different $B$. napus genotypes. In contrast, Eickermann (2011) found that the amount of feeding by $C$. pallidactylus larvae was negatively correlated with $4 \mathrm{OH}$ content in leaves of different genotypes of oilseed rape.

The results of the present glucosinolate analysis of stems were not consistent with similar studies obtained in the open field, where the number of eggs deposited by C. napi into main stems was positively dependent upon five glucosinolates (chapter III). However, the results obtained in open fields (chapter III and IV) identified no relationships between the number of $C$. napi larvae in the main stems and the glucosinolate contents of stems. These contrasting results might be due to induced changes of glucosinolate contents, which could 
have affected larval performance of C. napi. Glucosinolate contents of cruciferous plants can be induced by herbivore disruption, such as oviposition or feeding (Bodnaryk 1992; Bartlet et al. 1999a) and these induced changes might have affected food quality for C. napi larvae. Abundance of eggs could not be assessed in this study.

The number of $C$. napi larvae in the main stems was dependent upon the stem injury coefficient. Therefore, the stem injury coefficient can provide a parameter for rapid screening of a large assortment of $B$. napus genotypes for infestation by $C$. napi larvae. Eickermann (2011) also found a positive correlation between the stem injury coefficient and the number of C. pallidactylus larvae and Ferguson et al. (2003) reported a positive relationship between the stem injury coefficient and the number of $P$. chrysocephala larvae in B. napus. The larval instar index was not dependent upon basal stem diameters.

The larval development time of $C$. napi was reflected by the larval instar index. In the resynthesized line S30, which contained the lowest number of C. napi larvae, the larval development was delayed with higher proportion of L2 than L3, while in the resynthesized line L16, which contained the highest number of $C$. napi larvae, the larval development was not delayed. The larval instar index correlated positively with the number of $C$. napi larvae. Therefore, it did not seem that there was an intraspecific competition between the number of C. napi larvae present in the main stems.

Glucosinolates can adversely affect performance of specialist insects (Agrawal and Kurashige 2003). In Arabidopsis thaliana L. different glucosinolate contents affected performance of larvae of the mustard leaf beetle (Phaedon cochlearia (F.)) (Uddin et al. 2009). To determine antibiosis effects of genotypes on larval performance, the influence of the contents of glucosinolates in non-infested stems on the larval instar indices should be analyzed. However, this was not tested, because of multi-collinearity of the larval instar index with the number of $C$. napi larvae. No relationship between the number of $C$. napi larvae and the glucosinolate profile of stems was found, therefore no relationship between the larval instar index and the glucosinolate profile can be presumed.

Systematic changes of the glucosinolate profile of B. napus can be induced by feeding damage of P. chrysocephala (Bartlet et al. 1999a). Oviposition and larval feeding of C. napi might have changed glucosinolate contents. That is why most probably no relationship between the larval instar index and non-infested stem glucosinolates could be found and glucosinolates were not assessed from infested stems in the present study. The larval dry body mass of $2^{\text {nd }}$ and $3^{\text {rd }}$ larval instars of $C$. napi varied widely, but did not significantly differ 
between genotypes. However, larval weight of $P$. chrysocephala can be affected by the indolyl glucosinolate content $4 \mathrm{OH}$ of petioles of oilseed rape and turnip rape (Doering 2012).

In this semi-field multi-choice experiment, significant differences between individual genotypes were found. The resynthesized line S30 showed a low infestation by C. napi and larval performance was delayed. No clear relationship between the abundance of $C$. napi larvae in main stems and the length of stems of $B$. napus genotypes at the beginning of the oviposition period by $C$. napi could be revealed. No relationships between the larval abundance and performance of $C$. napi and the glucosinolate profiles of non-infested stems of B. napus genotypes were found. Therefore, further studies are needed to identify resistance mechanisms for infestation and performance of C. napi.

\section{Acknowledgement}

I would like to thank Prof. Dr. H. C. Becker for providing seeds of rare genotypes, H. Brandes, B. Olberg and U. Ammermann for glucosinolate analyses (Georg-August University). I am also grateful to Dr. C. Scherber for providing statistical multivariate model for glucosinolate analysis (Georg-August University) and M. Hervé for supplying multivariate statistic macro and further assistance (INRA, France). I would also like to thank the technical staff in the field: H. Reintke, G. Miotke and all student research assistants.

The study was funded by German Federal Ministry of Food, Agriculture and Consumer Protection (BMELV) and the Board of support for Private Plant Breeding in Germany (GFP). 
Chapter II

\section{References}

Agrawal AA, Kurashige NS (2003) A role for isothiocyanates in plant resistance against the specialist herbivore Pieris rapae. Journal of Chemical Ecology 29:1403-1415.

Alford DV, Nilsson C, Ulber B (2003) Insect pests of oilseed rape crops. In: DV Alford (Eds.), Biocontrol of oilseed rape pests. Blackwell Science Ltd., Oxford, pp 9-42.

Barker E, Rayens W (2003) Partial least squares for discrimination. Journal of Chemometrics $17,166-173$.

Bartlet E, Kiddle G, Williams I, Wallsgrove R (1999a) Wound-induced increases in the glucosinolate content of oilseed rape and their effect on subsequent herbivory by a crucifer specialist. Entomologia Experimentalis et Applicata 91:163-167.

Bartlet E, Williams I, Pickett J, Ellis P, Derridj S (1999b) The ideal glucosinolate profile for pest resistance in oilseed rape. IOBC WPRS BULLETIN 22 (10):13-17.

Becker HC, Engqvist GM, Karlsson B (1995) Comparison of rapeseed cultivars and resynthesized lines based on allozyme and RFLP markers. Theoretical and Applied Genetics 91:62-67.

Bodnaryk RP (1992) Effects of wounding on glucosinolates in the cotyledons of oilseed rape and mustard. Phytochemistry 31:2671-2677.

Bones AM, Rossiter JT (2006) The enzymic and chemically induced decomposition of glucosinolates. Phytochemistry 67:1053-1067.

Buechi R (1988) Neue Bekaempfungsschwelle fuer den Rapsstengelruessler Ceutorhynchus napi Gyll.. Mitteilungen der Schweizerischen Landwirtschaft 36:110-117.

Buechi R (1996) Eiablage des Rapsstengelruesslers Ceutorhynchus napi Gyll., in Abhaengigkeit der Stengellaenge bei verschiedenen Rapssorten. Anzeiger fuer Schaedlingskunde, Pflanzenschutz, Umweltschutz 69:136-139.

Chew F, Renwick J (1995) Host plant choice in Pieris butterflies. In: RT Carde and WJ Bell (Eds.), Chemical Ecology of Insects 2. Chapman and Hall, New York, Victoria, Scarborough, Col. Polanco, pp 214-238.

Cleemput S, Becker HC (2012) Genetic variation in leaf and stem glucosinolates in resynthesized lines of winter rapeseed (Brassica napus L.). Genetic Resources and Crop Evolution 59:539-546.

Dechert G, Ulber B (2004) Interactions between the stem-mining weevils Ceutorhynchus napi Gyll. and Ceutorhynchus pallidactylus (Marsh.) (Coleoptera: Curculionidae) in oilseed rape. Agricultural and Forest Entomology 6:193-198. 
Deubert K-H (1952) Ueber das durch die Eiablage von Ceutorrhynchus napi Gyll. (Col. Curc.) verursachte histologische Schadbild an Winterraps. Wissenschaftliche Zeitschrift der Martin-Luther-Universitaet Halle-Wittenberg 2:203-205.

Diederichsen E, Sacristan M (1991) Resynthesis of amphidiploid Brassica species and their clubroot disease reaction. Proc Rapeseed Cong, Saskatoon, Canada, 9-11 July 1991, 1: 274-279.

Doering A (2012) Performance of cabbage stem flea beetle larvae (Psylliodes chrysocephala L.) on brassicaceous host plants with different glucosinolate profile. In: A Doering (Eds.), Effect of plant characteristics on host plant selection and larval performance of specialist insect pests on Brassicaceae. Cuvillier, Goettingen, pp 19-35.

Dosdall L, Herbut M, Cowle N, Micklich T (1996) The effect of seeding date and plant density on infestations of root maggots, Delia spp. (Diptera: Anthomyiidae), in canola. Canadian Journal of Plant Science 76:169-177.

Dosse G (1951) Der grosse Kohltriebruessler Ceuthorrhynchus napi Gyll. Biologie, Schadenauftreten und Bekaempfung unter besonderer Beruecksichtigung. der " Gallbildung" an Kohlpflanzen: Mit 41 Abb.. Zeitschrift fuer Angewandte Entomologie 32:32-566.

Eickermann M (2011) Resynthesized lines and cultivars of Brassica napus L. provide sources of resistance to the cabbage stem weevil (Ceutorhynchus pallidactylus (Mrsh.)). Bulletin of Entomological Research 101:287-294.

Fahey JW, Zalcmann AT, Talalay P (2001) The chemical diversity and distribution of glucosinolates and isothiocyanates among plants. Phytochemistry 56:5-51.

Feng J, Long Y, Shi L, Shi J, Barker G, Meng J (2012) Characterization of metabolite quantitative trait loci and metabolic networks that control glucosinolate concentration in the seeds and leaves of Brassica napus. New Phytologist 193:96-108.

Fenwick G, Heaney R (1983) Glucosinolates and their breakdown products in cruciferous crops, foods and feedingstuffs. Food Chemistry 11:249-271.

Ferguson AW, Klukowski Z, Walczak B, Clark SJ, Mugglestone MA, Perry JN, Williams IH (2003) Spatial distribution of pest insects in oilseed rape: implications for integrated pest management. Agriculture, Ecosystems and Environment 95:509-521.

Geladi P, Kowalski B (1986) Partial least squares regression: A tutorial. Analytica Chimica Acta 185, 1-17. 
Giamoustaris A, Mithen R ( 1995) The effect of modifying the glucosinolate content of leaves of oilseed rape (Brassica napus ssp. oleifera) on its interaction with specialist and generalist pests. Annals of Applied Biology 126:347-363.

Girke A (2002) Neue Genpools aus resynthetisiertem Raps (Brassica napus L.) fuer die Hybridzuechtung. Dissertation, Georg-August University, Goettingen.

Girke A, Schierholt A, Becker HC (2012). Extending the rapeseed genepool with resynthesized Brassica napus L. I: genetic diversity. Genetic Resources and Crop Evolution 59:1441-1447.

Guenthart E (1949) Beitraege zur Lebensweise und Bekaempfung von Ceutorrhynchus quadridens Panz. und Ceutorrhynchus napi Gyll. mit Beobachtungen an weiteren Kohl- und Rapsschaedlingen. Mitteilungen der Schweizerischen Entomologischen Gesellschaft 22:441-591.

Halkier BA, Gershenzon J (2006) Biology and biochemistry of glucosinolates. Annual Review of Plant Biology 57:303-333.

Hopkins RJ, van Dam NM, van Loon JJA (2009) Role of glucosinolates in insect-plant relationships and multitrophic interactions. Annual Review of Entomology 54:57-83.

Kurtz B, Karlovsky P, Vidal S (2010) Interaction between western corn rootworm (Coleoptera: Chrysomelidae) larvae and root-infecting Fusarium verticillioides. Environmental Entomology 39:1532-1538.

Lancashire PD, Bleiholder H, Boom T, Langelueddeke P, Stauss R, Weber E, Witzenberger A (1991) A uniform decimal code for growth stages of crops and weeds. Annals of Applied Biology 119:561-601.

Le Pape H, Bronner R (1987) The effects of Ceutorhynchus napi (Curculionidae, Coleoptera) on stem tissue of Brassica napus var. oleifera. In: V Labeyrie, G Fabres and D Lachaise (Eds.), Insect-plants. Dr W Junk, Dordrecht, pp 207-212.

Lerin J (1993) Influence of the growth rate of oilseed rape on the splitting of the stem after an attack of Ceutorhynchus napi Gyll.. IOBC WPRS BULLETIN 16 (9):160-163.

Luehs W, Seyis F, Frauen M, Busch H, Frese L, Willner E, Friedt W, Gustafsson M, Poulsen G (2003) Development and evaluation of a Brassica napus core collection. Rudolf Mansfeld and Plant Genetic Resources 22:284-289.

Mayer AM (2004) Resistance to herbivores and fungal pathogens: variations on a common theme? A review comparing the effect of secondary metabolites, induced and constitutive, on herbivores and fungal pathogens. Israel Journal of Plant Sciences 52:279-292. 
McNaughton SJ (1983) Compensatory plant growth as a response to herbivory. Oikos 40:329336.

Mithen R (1992) Leaf glucosinolate profiles and their relationship to pest and disease resistance in oilseed rape. Euphytica 63:71-83.

Mithen R (2001) Glucosinolates-biochemistry, genetics and biological activity. Plant Growth Regulation 34:91-103.

Mrowczynski M (1998) Studies on pest damage of cultivars and lines of winter oilseed rape. IOBC WPRS BULLETIN 21 (5):153-154.

Nuss H (2004) Einfluss der Pflanzedichte und -architektur auf Abundanz und innnerpflanzliche Verteilung staengelminierender Schadinsekten in Winterraps. Dissertation, Georg-August University, Goettingen.

Olsson G (1960) Species crosses within the genus Brassica. Hereditas 46:351-386.

Olsson G, Ellerstrom S, Tsunoda S, Hinata K, Gomez-Campo C (1980) Polyploidy breeding in Europe. In: S Tsunoda, K Hinata and C Gomez-Campo (Eds.), Brassica crops and wild allies. Scientific Society Press, Tokyo, pp 167-190.

Paul H (2003) Raps - Krankheiten, Schaedlinge, Schadpflanzen. Agro Concept GmbH, Soest. Renwick JAA, Radke CD, Sachdev-Gupta K, Staedler E (1992) Leaf surface chemicals stimulating oviposition by Pieris rapae (Lepidoptera: Pieridae) on cabbage. Chemoecology 3:33-38.

Rodman JE, Karol KG, Price RA, Sytsma KJ (1996) Molecules, morphology, and dahlgren's expanded order capparales. Systematic Botany 21:289-307.

Rygulla W, Snowdon R, Eynck C, Koopmann B, von Tiedemann A, Luehs W, Friedt W (2007) Broadening the genetic basis of Verticillium longisporum resistance in Brassica napus by interspecific hybridization. Phytopathology 97:1391-1396.

Sarfraz M, Dosdall L, Keddie B (2006) Diamond-back moth - host plant interactions: implications for pest management. Crop Protection 25:625-639.

Scherf H (1964) Die Entwicklungsstadien der mitteleuropaeischen Curculioniden (Morphologie, Bionomie, Oekologie). Waldemar Kramer, Frankfurt.

Schoonhoven LM, van Loon JJA, Dicke M (2005) Insect-plant biology. Oxford University Press, Oxford.

Seyis F, Friedt W, Luehs W (2001) Resynthese-Raps (Brassica napus L.) als genetische Ressource fuer die Qualitaets- und Ertragszuechtung. Schriften zu Genetischen Ressourcen 16:91-112. 
Staedler E, Reifenrath K (2009) Glucosinolates on the leaf surface perceived by insect herbivores: review of ambiguous results and new investigations. Phytochemistry Reviews 8:207-225.

Thies W (1977) Analysis of glucosinolates in seeds of rapeseed (Brassica napus L.): concentration of glucosinolates by ion exchanges. Zeitschrift fuer Pflanzenzuechtung 79:331-335.

Uddin MM, Ulrichs C, Tokuhisa JG, Mewis I (2009) Impact of glucosinolate structure on the performance of the crucifer pest Phaedon cochleariae (F.). Journal of Applied Botany and Food Quality 82:108-113.

Ulmer BJ, Dosdall LM (2006) Glucosinolate profile and oviposition behavior in relation to the susceptibilities of Brassicaceae to the cabbage seedpod weevil. Entomologia Experimentalis et Applicata 121:203-213.

Van Loon JJA, Blaakmeer A, Griepink FC, van Beek TA, Schoonhoven LM, de Groot A (1992) Leaf surface compound from Brassica oleracea (Cruciferae) induces oviposition by Pieris brassicae (Lepidoptera: Pieridae). Chemoecology 3:39-44.

Velasco L, Becker HC (2000) Variability for seed glucosinolates in a germplasm collection of the genus Brassica. Genetic Resources and Crop Evolution 47:231-238.

Waligora D, Krzymanska J (1995) Biological activity of glucosinolates isolated from rape Brassica napus L. to some insects. Proc Rapeseed Cong, Cambridge, United Kingdom, 4-7 July 1995, 9:1022-1024.

Williams I (2004) Advances in insect pest management of oilseed rape in Europe. In: AR Horowitz and I Ishaaya (Eds.), Insect Pest Management. Springer, Berlin, Heidelberg, pp 181-208. 


\section{CHAPTER III}

Evaluation of resynthesized lines and cultivars of oilseed rape (Brassica napus L.) for oviposition preference and larval performance of rape stem weevil (Ceutorhynchus napi Gyll.)

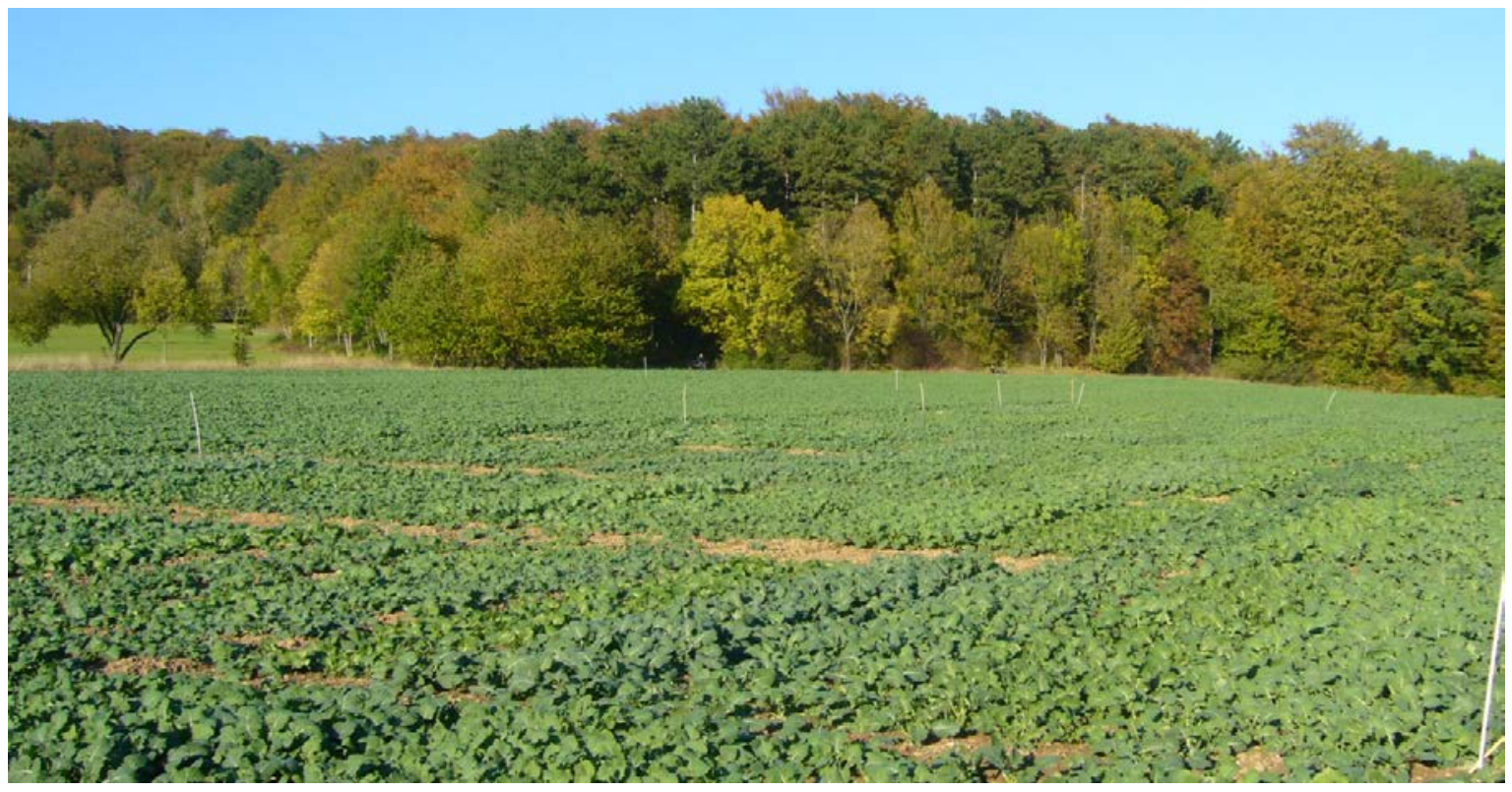




\section{Abstract}

The rape stem weevil, Ceutorhynchus napi Gyll. (Col., Curculionidae), is a serious pest in European winter oilseed rape crops. In spring, C. napi females deposit single eggs into the tips of elongating stems. The egg deposition may result in considerable disruption to growth and yield losses. Additionally, larvae feed within the stem pith tissue. In integrated pest management systems, resistant cultivars are needed to minimize the number of insecticide applications. Resynthesized lines of oilseed rape might have potential for increasing the level of resistance to this pest.

The susceptibility of five resynthesized lines, showing a broad genetic variability, and three cultivars of oilseed rape to $C$. napi was evaluated in a multi-choice field plot and in a no-choice laboratory experiment. In the field experiment, the number of eggs and larvae of $C$. napi were assessed from plant samples collected at weekly intervals from the beginning of the oviposition period in April 2013 to the occurrence of mature larvae in May 2013. To assess differences in the susceptibility of genotypes, the number of eggs and larvae of $C$. napi were determined. The number of eggs and larvae differed significantly between genotypes at several sampling dates. The resynthesized line S30 showed a significantly lower number of eggs and larvae than the resynthesized line H30 and cultivar Sollux. The low number of eggs in stems of S30 indicated antixenosis resistance. To determine differences of plant responses to oviposition, the degree of pith tissue degeneration in stems was assessed. In S30, pith tissue degeneration was significantly weaker than in H30. Further, morphological plant traits, glucosinolates and plant nutrients were assessed as potential mechanisms of resistance. The number of eggs was negatively dependent upon the stem length and positively upon levels of five glucosinolates, glucobrassicanapin, glucoalyssin, glucobrassicin, neoglucobrassicin and gluconasturtiin. A significantly delayed larval development in S30, compared to H30 indicated antibiosis resistance in S30. Additionally, S30 contained the lowest number of eggs in the no-choice laboratory experiment. Our data revealed that preference and performance of C. napi adults and larvae were both negatively influenced by S30, suggesting that specific parameters could be selected for a breed program enhancing the resistance against this herbivorous pest species.

\section{Keywords}

Resynthesized lines, glucosinolates, glucobrassicanapin, glucoalyssin, glucobrassicin, neoglucobrassicin, gluconasturtiin, host plant resistance, larval instar index 


\section{Introduction}

The univoltine rape stem weevil, Ceutorhynchus napi Gyll. (Col., Curculionidae), is one of the major pests in European winter oilseed rape crops (Brassica napus L.) (Alford et al. 2003). The process of egg deposition by females of $C$. napi may result in the twisting of stems (S-shaped stem), followed by distortion, considerable disruption to growth and yield losses (Dosse 1951; Buechi 1988; Alford et al. 2003). Additionally, larvae feed within the stem pith tissue (Dosse 1951). The life cycle has been studied by several authors (Guenthart 1949; Dosse 1951; Deubert 1952; Scherf 1964; Le Pape and Bronner 1987). Adult weevils migrate to oilseed rape crops in early spring. In March/April, after approximately two weeks of feeding, females deposit eggs into tips of elongating stems of oilseed rape plants. Larvae feed within the stem pith. In May/June, full-grown larvae leave the plant to pupate in soil. Adult weevils overwinter within earthen pupal cocoons. Females pass through an obligate, pre-reproductive diapause before they migrate to new crops the following spring.

Today, management of insect pests of oilseed rape is strongly based on synthetic insecticides (Williams 2010; Thieme et al. 2010). Because pyrethroids are primarily used for the control of the main insect pests, selection pressure for resistance is high (Thieme et al. 2010). In integrated pest management systems, resistant cultivars are needed to minimize the number of insecticide applications (Friedt et al. 2003). There are only few examples of screening brassicaceous genotypes for insect resistance traits, for instance to cabbage flea beetle (Phyllotreta nemorum (L.)) (Renwick 2002), cabbage stem weevil (Ceutorhynchus pallidactylus (Marsh.)) (Eickermann 2011) and cabbage seed weevil (Ceutorhynchus obstrictus (Marsh.)) (Cárcamo et al. 2007; Tansey and Dosdall 2011). Two studies aiming to screen for potential resistant cultivars did only find minor variation between the tested cultivars and lines with regard to infestation levels by C. napi (Mrowczynski 1998; Dechert and Ulber 2004). Resynthesized lines developed by interspecific crossing of the two progenitor species (Brassica oleracea L. X Brassica rapa L.) are broadening the genetic variation in oilseed rape (Olsson et al. 1980; Girke et al. 2012). Several studies have reported the potential of resynthesized lines as sources for the improvement of disease resistance (Diederichsen and Sacristan 1996; Rygulla et al. 2007) and pest resistance (Seyis et al. 2001; Eickermann 2011).

Resynthesized lines of oilseed rape are important genetic resources to modify the glucosinolate profiles of oilseed rape (Cleemput and Becker 2012). These glucosinolates can play an important role in the host acceptability of Brassica species to specialist crucifer pests (Giamoustaris and Mithen 1995; Schoonhoven et al. 2005; Ulmer and Dosdall 2006). They 
can influence feeding and oviposition behavior and may also affect the development of insect larvae (Renwick et al. 1992; Van Loon et al. 1992; Chew and Renwick 1995). Moreover, the presence of glucosinolates in crucifer plants has also been found to serve as defense compounds against non-specific insects (Feeny 1977; Giamoustaris and Mithen 1995). However, even specialist insects are not completely immune to the defense compounds of brassicaceous host plants (Ali and Agrawal 2012) and may be negatively affected by specific glucosinolates, e.g. the cabbage aphid (Brevicoryne brassicae (L.)) (Waligora and Krzymanska 1995), cabbage flea beetles (Phyllotreta spp.) (Siemens and Mitchelolds 1996), cabbage root fly (Delia radicum (L.)) (Tansey and Dosdall 2011) and cabbage stem weevil (C. pallidactylus (Marsh.)) (Eickermann 2011).

Plant nutrients can also affect oviposition preference and larval performance of herbivorous insects (Blake et al. 2010). Foliar nitrogen content as well as C:N ratio in plant tissue can have an influence on oviposition (Chen et al. 2004) and performance of herbivorous insects (Awmack and Leather 2002).

Beside plant metabolic compounds morphological plant traits do also contribute to herbivore resistance in oilseed rape (Sarfraz et al. 2006). Buechi (1996) revealed a clear preference of $C$. napi for a distinct oilseed rape development stage. Elongated stems which are longer than $22 \mathrm{~cm}$ are less preferred by C. napi females for oviposition (Buechi 1996).

Plants are able to respond to egg deposition by herbivorous insects. Deposited eggs can trigger various metabolic plant responses which in turn may affect egg hatching and development of larvae (Hilker et al. 2002; Hilker and Fatouros 2014). Already 24 hours after oviposition by $C$. napi, the stem pith tissue surrounding the deposited eggs begins to degenerate (Dosse 1951; Deubert 1955). Tissue changes in plants induced by egg deposition of herbivorous insects can affect egg development or hatching larvae (Hilker et al. 2002). However, there are no detailed studies about plant responses of different oilseed rape genotypes towards $C$. napi egg deposition. The egg deposition by C. pallidactylus can lead to an extensive wound callus tissue formation in petioles of oilseed rape and an increased mortality of egg batches (Nuss 2004).

The objective of this study was to evaluate the susceptibility of eight $B$. napus genotypes to oviposition preference and larval performance of $C$. napi and to identify potential sources of resistance, focusing on resynthesized lines and cultivars of oilseed rape. Plant infestations by eggs and larvae of $C$. napi were studied in a multi-choice field plot experiment. To determine larval performance of $C$. napi in response to these genotypes, the development was assessed by calculating the larval instar index. The length of the stem, stem 
biomass, glucosinolates and plant nutrients, were analyzed as potential plant cues affecting oviposition and larval performance of $C$. napi in the field. Additionally, oviposition by $C$. napi of these selected genotypes was assessed in a no-choice laboratory experiment.

\section{Material and Methods}

Field experiment

Susceptibility to oviposition and performance of C. napi: The susceptibility of eight genotypes of $B$. napus (Table 1) to oviposition and larval infestation of $C$. napi was studied in a multi-choice field plot experiment at the experimental station of Georg-August University in 2012/2013 (N51³3’56.3 E956’49.9). These genotypes were selected because of their broad genetic background according to Girke (2002) (Table 1). They were sown in a complete randomized block design with four replicates and plot size of $1.5 \mathrm{~m} \times 7.5 \mathrm{~m}$ on August $22^{\text {nd }}$, 2012. To avoid border effects, a mixture of the oilseed rape cultivars Trabant, Dimension and Electra were sown in the surrounding plots. Sowing density was 33 seeds $/ \mathrm{m}^{2}$. Natural crop colonization of $C$. napi was monitored by using four yellow traps $(33.0 \mathrm{~cm} \times 25.0 \mathrm{~cm} \times 7.3$ $\mathrm{cm}$ ), which were located around the experiment (one trap on each margin).

On April $15^{\text {th }}$, before oviposition of females into stems, six randomly selected plants of each plot were collected to assess the BBCH growth stage (Lancashire et al. 1991), biomass and dry weight of main stems. Stem dry weight was determined by drying the stems at $60{ }^{\circ} \mathrm{C}$ for three days and $120^{\circ} \mathrm{C}$ for one day. The dry weight of stems was assessed by using a scale (Sartorius TE 1502S). Five randomly selected plants of each plot were collected at weekly intervals from April $15^{\text {th }}$ to May $22^{\text {nd }}$ to determine the number of eggs and larvae of $C$. napi and to evaluate the length of the stems. Eggs and larvae were dissected from the main stems under a stereo microscope (Zeiss, Stemi 2000-C). Additionally, the stem samples of April $29^{\text {th }}$ were dissected to assess the pith tissue degeneration under the same stereo microscope. The degeneration of the pith tissue was classified into three categories (weak, moderate and strong).

The ratio between the number of larvae and the number of eggs deposited by $C$. napi into stems was calculated by dividing the number of larvae at peak larval infestation on May $13^{\text {th }}$ with the number of eggs at peak abundance of eggs on April $29^{\text {th }}$. Larval instars of $C$. napi were classified based on the head capsule width (Guenthart 1949). Larval instar index was calculated by subtracting the number of $3^{\text {rd }}$ larval instars by the number of $2^{\text {nd }}$ larval instars on May $22^{\text {nd }}$ and the summation of the constant $K(K=8$, to avoid negative values) 
(Kurtz et al. 2010). The larval dry body mass of ten larvae per larval instar and plot was determined by drying the larvae at $60{ }^{\circ} \mathrm{C}$ for three days. The weights of individual larvae were assessed using a scale (Sartorius micro scale, MC5).

Chemical analysis of plants: Five randomly selected non-infested stems per plot were sampled for glucosinolate analysis on April $17^{\text {th }}$. The stems were frozen on dry ice and stored at $-20{ }^{\circ} \mathrm{C}$. Each sample was freeze-dried for 96 hours and homogenized using a mill (Krups KM 75). Stem glucosinolates were separated and individual compounds were identified and quantified (Thies 1977). Desulfoglucosinolates were extracted as detailed in Cleemput and Becker (2012). Glucosinolates were analyzed using Shimadzu Prominence LC20AT series HPLC (Shimadzu Deutschland GmbH) equipped with a Nucleodur 100-3 C18 column (Macherey Nagel). Desulfoglucosinoltes were separated using a water-acetonitrile gradient (solvent A water, solvent B acetonitrile; 0-20 min 1-20\% B; 20-25 min 20\% B; 25-27 min 20 $\% \mathrm{~B} ; 27-34 \mathrm{~min} 1 \% \mathrm{~B}$ ) at a flow rate of $0.6 \mathrm{ml} / \mathrm{min}$. Retention times of known standards were used to identify desulfoglucosinolates. Glucosinolate contents were expressed in $\mu \mathrm{mol} /$ g dry weight (D.W.).

To analyze glucosinolate contents of infested stems, five randomly selected infested stems per plot were sampled for glucosinolate analysis on May $24^{\text {th }}$. The stem glucosinolates were analyzed as described above.

The $\mathrm{N}_{\min }\left(36.0 \mathrm{~kg} \mathrm{~N} / \mathrm{ha}\right.$ ) in the soil was assessed once on Mach $5^{\text {th }} 2013$. All plots were supplied with $177 \mathrm{~kg} \mathrm{~N} /$ ha (54 kg N / ha on March $4^{\text {th, }}, 42 \mathrm{~kg} \mathrm{~N} /$ ha on March $26^{\text {th }}$ and $81 \mathrm{~kg} \mathrm{~N} /$ ha on April $23^{\text {rd }}$ ). Six randomly selected non-infested stems per plot were sampled for nitrogen and carbon content on April $15^{\text {th }}$. The stems were dried at $60{ }^{\circ} \mathrm{C}$ for three days, milled by using a centrifugal mill and analyzed by a CN element analyzer (Vario EL, Fa. Elementar Analysensysteme GmbH, Hanau).

\section{Laboratory experiment}

No-choice oviposition tests were conducted to evaluate the susceptibility of the eight selected genotypes of $B$. napus (Table 1 ) to $C$. napi. Adult weevils used for screening were collected from the last year's oilseed rape crop in March 2013. They were kept in plastic boxes in the climatic chamber at $6{ }^{\circ} \mathrm{C}$ (L16:D8) on leaves of the spring rape cultivar Mozart. These adults were maintained up to three months with negligible mortality for use in the test. Plants were grown in a standard soil substrate (Fruhstorfer Substrat T25) to the 2-true-leaf stage in the greenhouse, transferred to a climatic chamber for vernalization for ten weeks at 2 ${ }^{\circ} \mathrm{C}$ (L8:D16) and returned to the greenhouse for plant elongation growth. Plants with BBCH 
growth stage 34-38 were transferred in a climatic chamber at $18{ }^{\circ} \mathrm{C}$ (L16:D8) for three days before being used for the experiment. Three post-diapause $C$. napi females were caged on each plant stem by using perforated plastic bags. Sex of the weevils was determined under a stereo microscope (Zeiss, Stemi 2000-C) using characteristics according to Guenthart (1949). After three days weevils were removed from the plants. Eggs deposited by C. napi into stems of the test genotypes were dissected after four days by using a stereo microscope (Zeiss, Stemi 2000-C).

Table 1 Genotypes of Brassica napus selected for evaluation of susceptibility to Ceutothynchus napi in laboratory and field experiment in 2012/2013, according to Grike (2002)

\begin{tabular}{|c|c|c|c|}
\hline Genotype & Type & Mother & Father \\
\hline S3 & resynthesized line & B. rapa ssp. rapa & $\begin{array}{l}\text { B. oleracea convar. acephala var. } \\
\text { sabellica }\end{array}$ \\
\hline S30 & resynthesized line & $\begin{array}{l}\text { B. oleracea convar. capitata var. } \\
\text { capitata }\end{array}$ & B. rapa ssp. pekinensis \\
\hline G53 & resynthesized line & $\begin{array}{l}\text { B. oleracea convar. capitata var. } \\
\text { capitata }\end{array}$ & $\begin{array}{l}\text { B. rapa ssp. nipposinica var. } \\
\text { perviridis }\end{array}$ \\
\hline H113 & resynthesized line & $\begin{array}{l}\text { B. oleraceae convar. capitata var. } \\
\text { sabauda }\end{array}$ & B. rapa ssp. pekinensis \\
\hline H30 & resynthesized line & B. rapa ssp. chinensis & B. napus var. pabularia \\
\hline Sollux & winter rape, OP cultivar & \multicolumn{2}{|c|}{ B. napus var. biennis } \\
\hline Oase & winter rape, OP cultivar & \multicolumn{2}{|c|}{ B. napus var. biennis } \\
\hline Mendel & winter rape, hybrid cultivar & \multicolumn{2}{|c|}{ B. napus var. biennis } \\
\hline
\end{tabular}

\section{Data Analysis}

Univariate data analysis was done using Statistica 10 (StatSoft ${ }^{\circledR}$, Tulsa, USA), while multivariate data analysis was done with R 3.0.1. All data was tested for normal distribution with Shapiro-Wilks W Test.

Univariate data analysis: The effects of plant genotype on stem biomass and on stem length on April $15^{\text {th }}$ and $29^{\text {th }}$ were analyzed by factorial one-way analysis of variance (ANOVA); the differences among means were evaluated by the Bonferroni Test. The effects of genotype on stem dry biomass, stem length on April $22^{\text {nd }}$ and on stem nitrogen content, carbon content and C:N ratio on April $15^{\text {th }}$ were each assessed using factorial one-way Kruskal-Wallis variance analyses (KW-ANOVA); the differences among ranks were evaluated by Kruskal-Wallis Test. The stem length on April $22^{\text {nd }}$ was analyzed differently from April $15^{\text {th }}$ and $29^{\text {th }}$ because of non-normal distribution of residuals on April $22^{\text {nd }}$. The 
stem length was analyzed only on three of the six measuring dates, because oviposition had peaked by April $29^{\text {th }}$ and so this early period was of most importance to the relationship with C. napi.

The effects of the genotype on the number of eggs deposited by $C$. napi on sampling dates April 22 ${ }^{\text {nd }}$, April $29^{\text {th }}$ and May $6^{\text {th }}$ were each assessed using ANOVA. Counts of eggs on May $6^{\text {th }}$ were $\log x+1$ transformed to normalize the residuals. ANOVA was also performed to evaluate the genotype effect on the number of larvae on May $13^{\text {th }}$. Numbers of eggs on May $13^{\text {th }}$ and numbers of larvae on April $22^{\text {nd }}$ and $29^{\text {th }}$, and May $6^{\text {th }}$ and $22^{\text {nd }}$ were too small and non-normally distributed for analysis by ANOVA and so the non-parametric test KWANOVA was used to analyse the effect of plant genotype on these data.

Effects of plant genotype on the larval instar index, dry body mass of larval instars, larvae:egg ratio and of genotype on stem pith degeneration in response to oviposition / egg presence were analyzed by KW-ANOVA.

To analyze the influence of physical plant traits on infestation by $C$. napi, linear regression was used to test the effect of stem biomass on the number of eggs in samples during the period of peak oviposition (April $22^{\text {nd }}$ and $29^{\text {th }}$, May $6^{\text {th }}$ ) and to test the effect of stem length on egg number on April $29^{\text {th }}$. The egg number was analyzed only on one of the six sampling dates, because oviposition had peaked by April $29^{\text {th }}$. Pearson Product-Moment Correlation was used to test the relationship between the number of larvae on May $22^{\text {nd }}$ and the larval instar index on the same date.

The Mann-Whitney Test was conducted to compare the total glucosinolate content of non-infested stems with the total glucosinolate content of infested stems.

Multivariate data analysis: To test both non-infested and infested stems for betweengenotype differences in glucosinolate profiles, Partial Least Squares - Discriminant Analysis (PLS-DA; function 'plsda', package 'mixOmics'; Barker and Rayens 2003) was used, and significance of discrimination was tested by multivariate analysis of variance (MANOVA). A Partial Least Squares Regression (PLSR; Geladi and Kowalski 1986) was applied to investigate the relationship between the glucosinolate profile of non-infested stems and the number of eggs on April 22 ${ }^{\text {nd }}$, April $29^{\text {th }}$ and May $6^{\text {th }}$ (function 'pls' regression mode, package 'mixOmics'). Data were scaled to unit variance, and were mean centered by default in the analyses. PLSR was also applied to investigate the relationship between the glucosinolate profile of infested stems and the number of larvae on May $13^{\text {th }}$ and May $22^{\text {nd }}$ and larval instar 
index. Samples of April $29^{\text {th }}$ and May $6^{\text {th }}$ were excluded from the analysis due to nonsignificant differences in the number of larvae between genotypes.

\section{Results}

Field experiment

Susceptibility to oviposition by C. napi and morphological plant traits and plant nutrients: The main immigration of $C$. napi into the oilseed rape field occurred on April $7^{\text {th }}$ 2013. On April 15 ${ }^{\text {th }}$, before the beginning of the oviposition period of C. napi (Fig. 1 and Table 3), the resynthesized line S30 and the cultivar Oase were at BBCH growth stage 51, while the other test genotypes were at $\mathrm{BBCH}$ growth stage 50 (Table 2). On sampling dates April $15^{\text {th }}$, April $22^{\text {nd }}$ and April $29^{\text {th }}$ the length of the plant stem differed significantly between genotypes $\left(F_{7,24}=4.538, P=0.002\right),(H(7, N=32)=22.778, P=0.002),\left(F_{7}, 24=21.439\right.$, $P=0.000$ ), respectively (Table 2). On sampling dates April $15^{\text {th }}$ and April $22^{\text {nd }}$, the cultivar Sollux showed the shortest stem length, while on April $29^{\text {th }}$ the resynthesized line H30 had the shortest stem length (Table 2).

Table 2 Plant traits of eight B. napus genotypes grown in the field experiment 2012/2013. BBCH growth stages according to Lancashire (1991). Mean values ( \pm SE) of four replicates. Different letters within each column indicate significant differences between genotypes, $P \leq 0.05$. Length of main stems on April $15^{\text {th }}$ and $29^{\text {th }}$, Bonferroni Test; Length of main stems on April $22^{\text {nd }}$, Kruskal-Wallis Test

\begin{tabular}{|c|c|c|c|c|}
\hline Genotype & $\begin{array}{l}\text { BBCH } \\
\text { April } 15^{\text {th }}\end{array}$ & $\begin{array}{l}\text { Length of stem } \\
\text { April } 15^{\text {th }}(\mathrm{cm})\end{array}$ & $\begin{array}{l}\text { Length of stem } \\
\text { April } 22^{\text {nd }}(\mathrm{cm})\end{array}$ & $\begin{array}{l}\text { Length of stem } \\
\text { April } 29^{\text {th }}(\mathrm{cm})\end{array}$ \\
\hline S3 & 50 & $8.65 \pm 0.93 \mathrm{abc}$ & $23.30 \pm 1.60 \mathrm{ab}$ & $56.48 \pm 4.97 \mathrm{ab}$ \\
\hline S30 & 51 & $9.94 \pm 1.10 a b$ & $25.25 \pm 2.74 \mathrm{ab}$ & $61.05 \pm 3.10 \mathrm{a}$ \\
\hline G53 & 50 & $7.77 \pm 0.38$ abc & $22.05 \pm 0.75 \mathrm{ab}$ & $64.15 \pm 2.14 \mathrm{a}$ \\
\hline H113 & 50 & $6.61 \pm 0.29$ bc & $19.48 \pm 1.19 a b$ & $45.53 \pm 2.49$ bc \\
\hline Н30 & 50 & $7.18 \pm 0.88 \mathrm{abc}$ & $15.40 \pm 0.29 a b$ & $32.28 \pm 2.07 \mathrm{~d}$ \\
\hline Sollux & 50 & $5.63 \pm 0.79 \mathrm{c}$ & $14.03 \pm 0.31 b$ & $37.18 \pm 2.79 \mathrm{~cd}$ \\
\hline Oase & 51 & $10.54 \pm 0.59 \mathrm{a}$ & $25.40 \pm 0.78 \mathrm{a}$ & $56.05 \pm 1.20 \mathrm{ab}$ \\
\hline Mendel & 50 & $8.57 \pm 0.89 a b c$ & $23.97 \pm 0.73 \mathrm{ab}$ & $66.73 \pm 1.32 \mathrm{a}$ \\
\hline
\end{tabular}

On sampling date April $22^{\text {nd }}$, the number of eggs in main stems differed significantly between genotypes $\left(F_{7,24}=4.578, P=0.002\right)$. The resynthesized line S30 contained significantly less eggs in main stems compared to cultivars Oase and Mendel (Fig. 1 and Table 3). On April $29^{\text {th }}$, an average peak abundance of eggs was reached (Table 3). On this sampling date, the number of eggs in main stems differed significantly between genotypes $\left(F_{7,24}=8.363, P=\right.$ 0.000). S30 showed a significantly lower number of eggs in main stems compared to cultivar Sollux and resynthesized lines H30 and H113 (Fig. 1 and Table 3). On sampling date May $6^{\text {th }}$, 
the number of eggs differed significantly between genotypes $\left(F_{7,24}=5.159, P=0.001\right)$. S30 contained a significantly lower number of eggs compared to Sollux and H30 (Fig. 1 and Table 3). On May $13^{\text {th }}$, the genotype did not affect the number of eggs laid by $C$. napi $(H(7, N=32)$ =9.679, $P=0.208$ ) (Fig. 1 and Table 3).

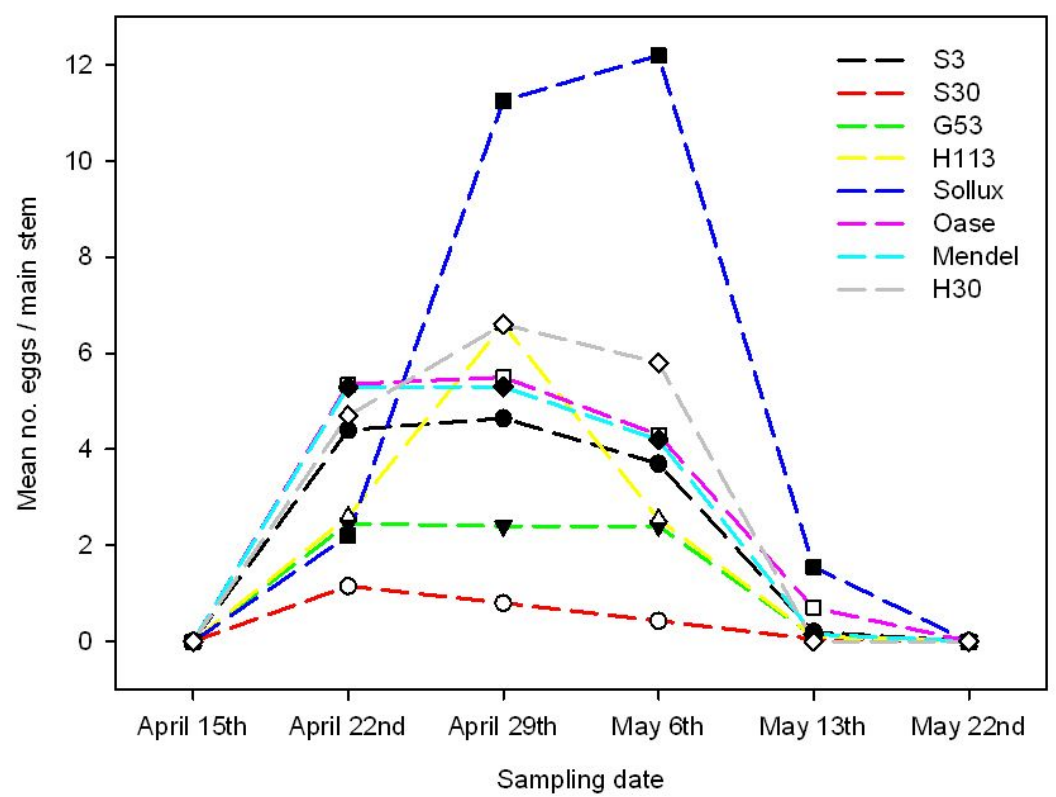

Fig. 1 Number of eggs laid by Ceutorhynchus napi into stems of eight Brassica napus genotypes on six sampling dates. Genotypes were grown in the field experiment in 2012/2013 in four replicates

Table 3 Number of eggs deposited by C. napi into main stems of eight Brassica napus genotypes on six sampling dates. Genotypes were grown in the field experiment in 2012/2013. Mean values ( \pm SE) of four replicates. Different letters within each column indicate significant differences between genotypes, $P \leq 0.05$. Number of eggs on April $22^{\text {nd }}$ and $29^{\text {th }}$ and May $6^{\text {th }}$, Bonferroni Test

\begin{tabular}{llllllll}
\hline & \multicolumn{5}{c}{ Mean no. eggs / main stem \pm SE } \\
Genotype & April 15 $^{\text {th }}$ & April 22 & April 29 & May 6 $^{\text {th }}$ & May 13 $^{\text {th }}$ & May 22 $^{\text {nd }}$ & Mean $^{\text {An }}$ \\
\hline S3 & 0.0 & $4.40 \pm 0.56 \mathrm{ab}$ & $4.65 \pm 0.38 \mathrm{bc}$ & $3.70 \pm 1.78 \mathrm{abc}$ & $0.20 \pm 0.14$ & 0.0 & 2.16 \\
S30 & 0.0 & $1.15 \pm 0.63 \mathrm{~b}$ & $0.80 \pm 0.29 \mathrm{c}$ & $0.43 \pm 0.10 \mathrm{c}$ & $0.05 \pm 0.05$ & 0.0 & 0.41 \\
G53 & 0.0 & $2.45 \pm 0.40 \mathrm{ab}$ & $2.40 \pm 0.22 \mathrm{bc}$ & $2.40 \pm 1.41 \mathrm{bc}$ & $0.10 \pm 0.10$ & 0.0 & 1.23 \\
H113 & 0.0 & $2.60 \pm 0.81 \mathrm{ab}$ & $6.60 \pm 0.80 \mathrm{ab}$ & $2.55 \pm 0.86 \mathrm{bc}$ & $0.10 \pm 0.06$ & 0.0 & 1.98 \\
H30 & 0.0 & $4.70 \pm 1.01 \mathrm{ab}$ & $6.60 \pm 1.52 \mathrm{ab}$ & $5.80 \pm 1.38 \mathrm{ab}$ & $0.00 \pm 0.00$ & 0.0 & 2.85 \\
Sollux & 0.0 & $2.20 \pm 0.34 \mathrm{ab}$ & $11.25 \pm 1.82 \mathrm{a}$ & $12.20 \pm 2.99 \mathrm{a}$ & $1.55 \pm 0.71$ & 0.0 & 4.53 \\
Oase & 0.0 & $5.35 \pm 0.68 \mathrm{a}$ & $5.50 \pm 1.40 \mathrm{abc}$ & $4.30 \pm 1.14 \mathrm{abc}$ & $0.70 \pm 0.57$ & 0.0 & 2.64 \\
Mendel & 0.0 & $5.30 \pm 1.19 \mathrm{a}$ & $5.30 \pm 0.88 \mathrm{bc}$ & $4.20 \pm 1.08 \mathrm{abc}$ & $0.15 \pm 0.15$ & 0.0 & 2.49 \\
\hline Mean & 0.0 & 3.52 & 5.39 & 4.45 & 0.36 & 0.0 & 2.29 \\
\hline
\end{tabular}


The number of eggs laid by C. napi in samples of April $29^{\text {th }}$ was significantly negative dependent upon length of the plant stems on April $22^{\text {nd }}$ (Fig. 2).

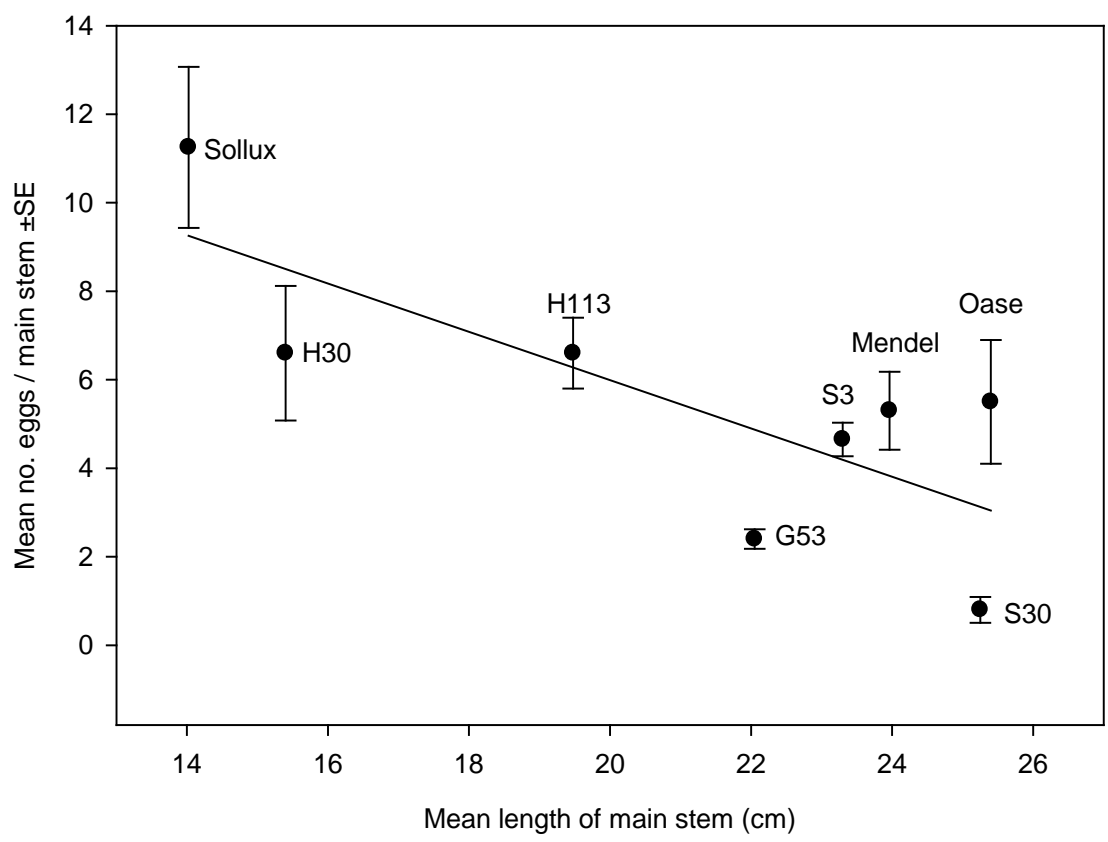

Fig. 2 Relationship between the number of eggs laid by Ceutorhynchus napi into stems of samples on April $29^{\text {th }}$ and the length of stems of eight Brassica napus genotypes on April $22^{\text {nd }}$. Genotypes were grown in the field experiment in 2012/2013. Regression model: $\mathrm{y}=16.912-0.546 \mathrm{x} ; R=0.770, F=8.724, P=0.025$

The stem biomass differed significantly between genotypes $\left(F_{7}, 24=2.704, P=\right.$ 0.024). The resynthesized line H113 accumulated a significantly lower stem biomass compared to the cultivar Oase (Table 4). The mean number of eggs laid by C. napi in samples of April $22^{\text {nd }}$ and $29^{\text {th }}$ or May $6^{\text {th }}$ were not dependent upon the stem biomass on 15 April $(R=$ $0.420, F=1.283, P=0.301),(R=0.330, F=0.735, P=0.424),(R=0.191, F=0.228, P=$ 0.650), respectively. Overall, the genotype had no effect on the stem dry biomass $(H(7, N=$ $32)=8.665, P=0.278$ ) (Table 4). The nitrogen content of stems did not significantly differ between genotypes $(H(7, N=32)=13.994, P=0.051)$ (Table 4). Overall, the genotype had also no effect on the carbon content $(H(7, N=32)=12.119, P=0.097)$ and C:N ratio of stems $(H(7, N=32)=12.784, P=0.078)($ Table 4$)$. 
Table 4 Above ground main stem biomass and contents of nutrients in main stems of eight Brassica napus genotypes on April $15^{\text {th }}$. Genotypes were grown in the field experiment in 2012/2013. Mean values ( \pm SE) of four replicates. Different letters within each column indicate significant differences between genotypes; Stem biomass; Bonferroni Test, $P \leq 0.05$

\begin{tabular}{lcllll}
\hline Genotype & Stem biomasse (g) & $\begin{array}{l}\text { Stem dry } \\
\text { biomass }(\mathrm{g})\end{array}$ & N content (\%) & C content (\%) & C:N ratio \\
\hline S3 & $7.13 \pm 1.86 \mathrm{ab}$ & $2.82 \pm 0.66$ & $5.77 \pm 0.08$ & $42.13 \pm 0.16$ & $7.30 \pm 0.07$ \\
S30 & $9.93 \pm 2.46 \mathrm{ab}$ & $3.83 \pm 1.01$ & $5.29 \pm 0.09$ & $40.99 \pm 0.32$ & $7.75 \pm 0.12$ \\
G53 & $8.25 \pm 0.63 \mathrm{ab}$ & $2.30 \pm 0.22$ & $6.02 \pm 0.23$ & $41.47 \pm 0.45$ & $6.89 \pm 0.21$ \\
H113 & $5.21 \pm 0.75 \mathrm{~b}$ & $2.34 \pm 0.37$ & $5.69 \pm 0.25$ & $41.39 \pm 0.18$ & $7.27 \pm 0.32$ \\
H30 & $7.32 \pm 2.14 \mathrm{ab}$ & $2.27 \pm 0.62$ & $5.96 \pm 0.32$ & $40.87 \pm 0.13$ & $6.86 \pm 0.40$ \\
Sollux & $7.06 \pm 0.92 \mathrm{ab}$ & $2.27 \pm 0.30$ & $5.94 \pm 0.23$ & $41.02 \pm 0.42$ & $6.91 \pm 0.27$ \\
Oase & $13.12 \pm 1.38 \mathrm{a}$ & $3.72 \pm 0.26$ & $5.04 \pm 0.14$ & $40.76 \pm 0.43$ & $8.09 \pm 0.29$ \\
Mendel & $10.95 \pm 1.19 \mathrm{ab}$ & $2.92 \pm 0.24$ & $5.36 \pm 0.19$ & $40.91 \pm 0.25$ & $7.78 \pm 0.27$ \\
\hline
\end{tabular}

Pith tissue changes in plants induced by egg deposition of C. napi: The extend of degeneration of the pith tissue surrounding the deposited eggs significantly differed between the genotypes $(H(7, N=32)=19.013, P=0.008)$ (Table 5). The degeneration of stem pith tissue in resynthesized line S30 was significantly lower than in resynthesized line H30. The pith tissue degeneration related on one deposited egg was not affected by the genotype $(H$ ( 7 , 32) $=9.614, P=0.212$ ) (Table 5).

Table 5 Severity of pith tissue degeneration in main stem and pith tissue degeneration in main stem related on one egg of eight Brassica napus genotypes of samples on April $29^{\text {th }}$. Genotypes were grown in field experiment in $2012 / 2013$. Mean values $( \pm$ SE) of four replicates. Different letters within each column indicate significant differences between genotypes. Pith tissue degeneration in stem, Kruskal-Wallis Test, $P \leq 0.05$. Degrees of stem pith tissue degeneration ( 1 = weak, 2 = moderate, 3 = strong)

\begin{tabular}{lll}
\hline Genotype & $\begin{array}{l}\text { Pith tissue degeneration } \\
\text { in stem }\end{array}$ & $\begin{array}{l}\text { Pith tissue degeneration } \\
\text { in stem / deposited egg }\end{array}$ \\
\hline S3 & $2.0 \pm 0.4 \mathrm{ab}$ & $0.4 \pm 0.1$ \\
S30 & $1.0 \pm 0.0 \mathrm{~b}$ & $0.7 \pm 0.1$ \\
G53 & $2.1 \pm 0.1 \mathrm{ab}$ & $0.5 \pm 0.0$ \\
H113 & $2.5 \pm 0.0 \mathrm{ab}$ & $0.4 \pm 0.1$ \\
H30 & $2.9 \pm 0.1 \mathrm{a}$ & $0.5 \pm 0.1$ \\
Sollux & $2.7 \pm 0.2 \mathrm{ab}$ & $0.2 \pm 0.1$ \\
Oase & $1.9 \pm 0.3 \mathrm{ab}$ & $0.3 \pm 0.1$ \\
Mendel & $2.3 \pm 0.3 \mathrm{ab}$ & $0.4 \pm 0.1$ \\
\hline
\end{tabular}

Susceptibility to oviposition by C. napi and glucosinolates of non-infested stems: The multivariate PLS-DA analysis and the associated MANOVA revealed that the glucosinolate profiles of non-infested stems differed significantly between genotypes (Fig. 3). The score plot explained $69.79 \%$ of the intergenotypic variance. The glucosinolate profiles of H30, 
S30, Mendel and Oase were more close to each other compared to the profiles of Sollux, H113, G53 and S3, respectively (Fig. 3). The non-infested stems of Sollux exhibited the highest mean total glucosinolate content, while S30 contained the lowest content (Table 8).

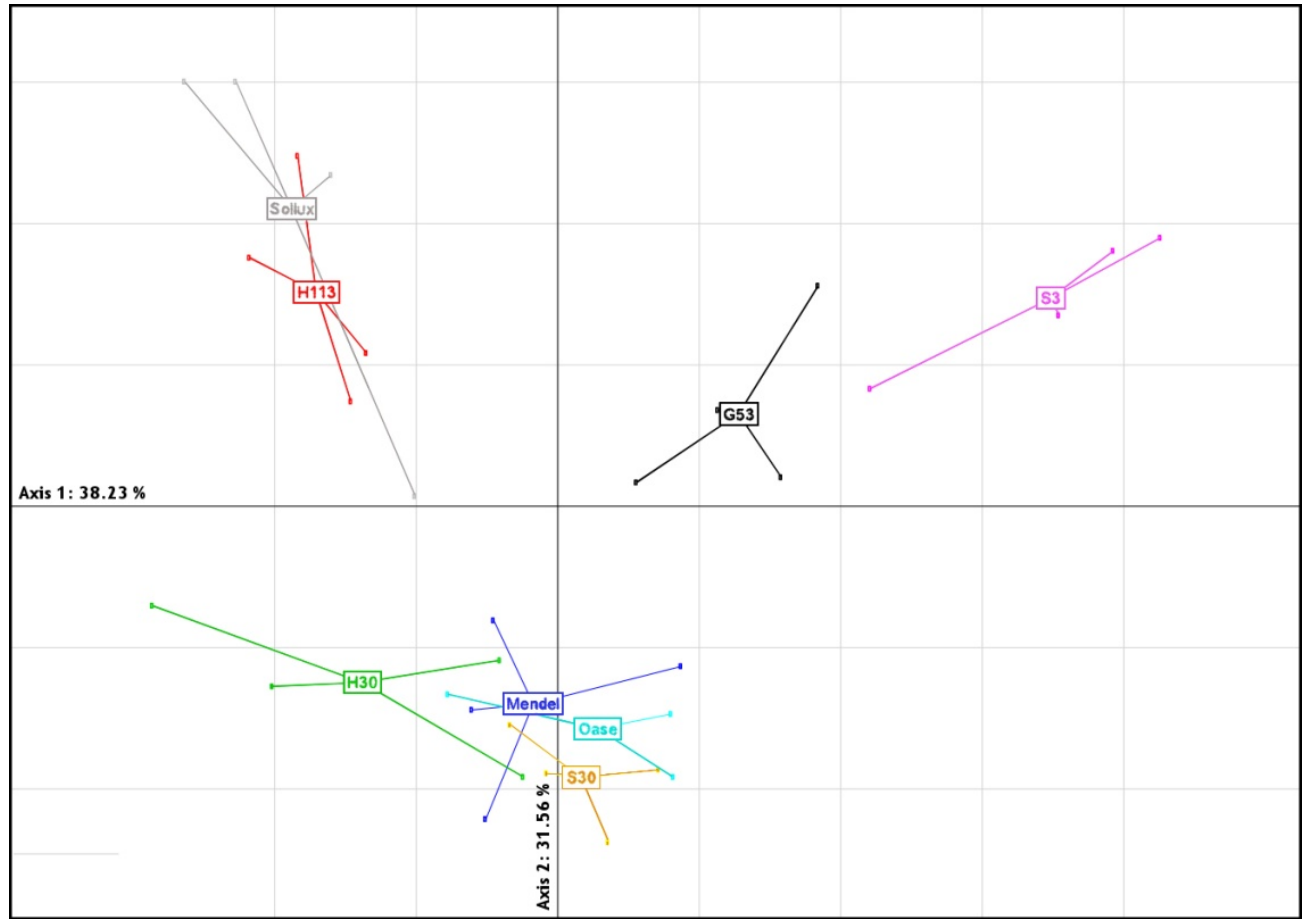

Fig. 3 Score plot of the Partial Least Squares - Discriminant Analysis. PLS-DA analysis performed on the glucosinolate profiles of non-infested stems of samples on April $17^{\text {th }}$ (score plot explained $69.79 \%$ of the intergenotypic variance; results of the MANOVA testing for the discrimination of genotypes: pseudo- $F$ 77,133 $=$ 4.149, $P<0.001)$

The multivariate PLSR analysis identified that there was a close relationship between the number of eggs in samples of April $29^{\text {th }}$ and the glucosinolate profile of non-infested stems. The factorial map 1-2 explained 51.17 \% variance of the number of eggs (Fig.4). The number of eggs was positively dependent upon the glucosinolates glucoalyssin (ALY), gluconasturtiin (NAS), glucobrassicanapin (GBN), glucobrassicin (GBC) and neoglucobrassicin (NEO). The smaller the angle between the egg arrow and the glucosinolate arrow the tighter were the two variables correlated and vice versa. Glucosinolates with short arrows ( $\leq$ radius) were found to be unrepresentative in the PLSR analysis (Fig. 4). The second and third PLSR analysis revealed no relationship between the number of eggs in samples of April $22^{\text {nd }}$ and May $6^{\text {th }}$ and the glucosinolate profile of non-infested stems (eggs in samples of April $22^{\text {nd }}: 24.07 \%$ variance of number of eggs, eggs in samples of May $6^{\text {th: }}: 29.31 \%$ variance of number of eggs). 


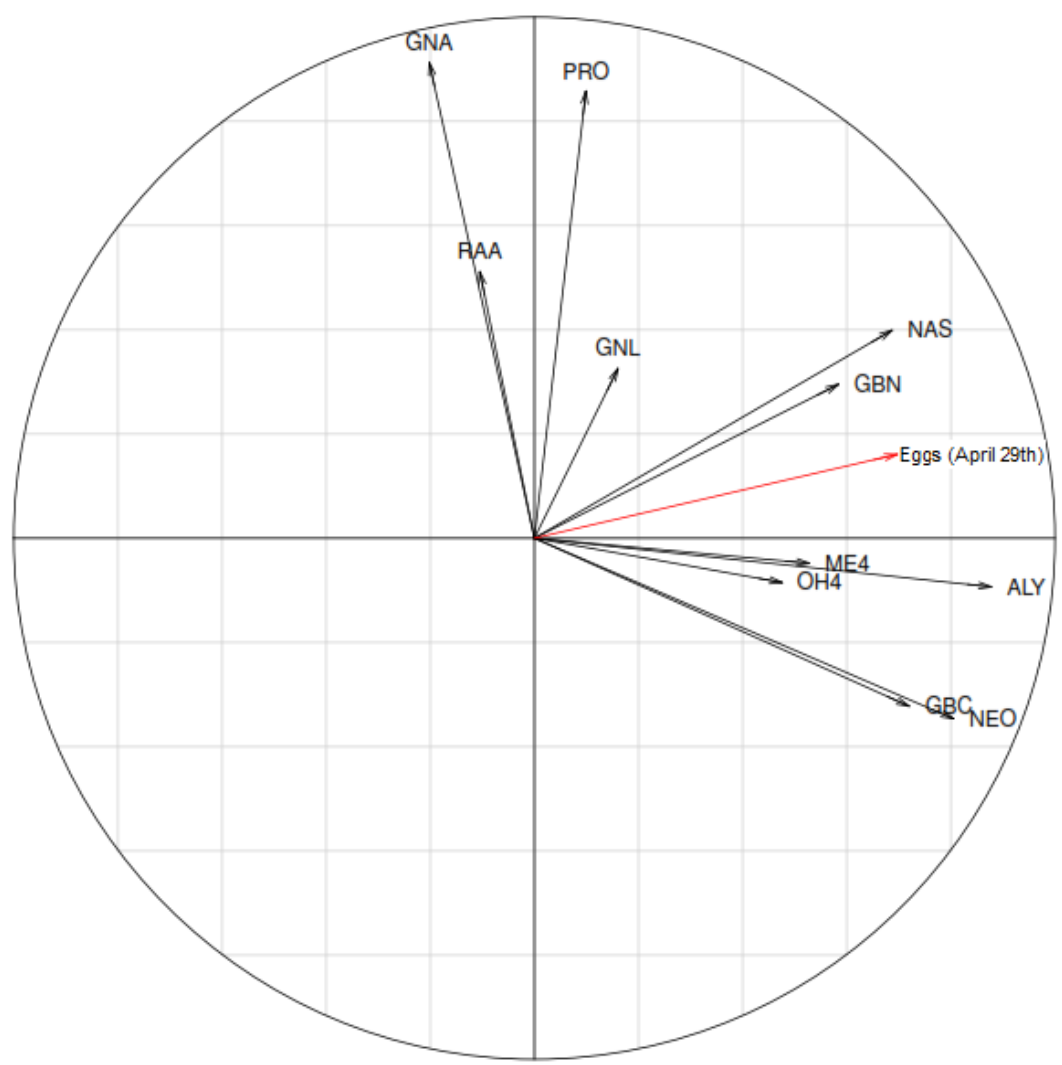

Fig. 4 Loading Plot of the Partial Least Squares Regression analysis indicating the relationship between the number of eggs laid by Ceutorhynchus napi in main stems of samples on April $29^{\text {th }}$ and the glucosinolate profile of non-infested stems of eight Brassica napus genotypes of samples on April $17^{\text {th }}$. The factorial map 1-2 explained $51.17 \%$ variance of the number of eggs. Aliphatic glucosinolates: $\mathrm{PRO}=$ progoitrin, $\mathrm{GNL}=$ napoleiferin, $\mathrm{ALY}=$ glucoalyssin, $\mathrm{GNA}=$ gluconapin, $\mathrm{GBN}=$ glucobrassicanapin, $\mathrm{RAA}=$ glucoraphanin; Indolyl glucosinolates: $4 \mathrm{OH}=$ 4-hydroxyglucobrassicin, $\mathrm{GBC}=$ glucobrassicin, $4 \mathrm{ME}=4$ methoxyglucobrassicin, NEO = neoglucobrassicin; Aromatic glucosinolate: NAS = gluconasturtiin

Additionally, univariate data analysis revealed that the number of eggs laid by C. napi in samples of April $29^{\text {th }}$ were positively dependent on the indolyl glucosinolate glucobrassicin (GBC) (Fig. 5). 


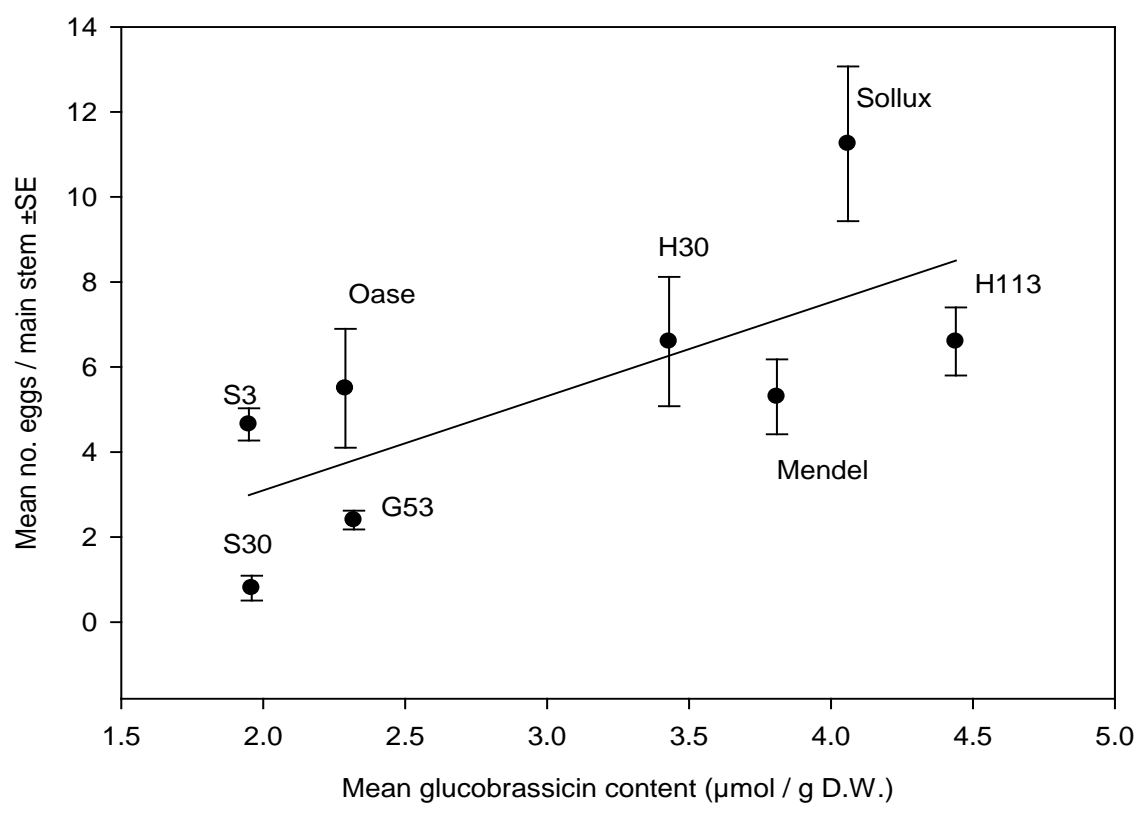

Fig. 5 Relationship between the number of eggs laid by Ceutorhynchus napi into stems of samples on April $29^{\text {th }}$ and glucobrassicin content of non-infested stems of eight Brassica napus genotypes of samples on April $17^{\text {th }}$. Genotypes were grown in the field experiment in 2012/2013. Regression model: $\mathrm{y}=-1.331+2.215 \mathrm{x} ; R=0.721$, $F=6.486, P=0.044)$

Performance of C. napi larvae: In plant samples of April $22^{\text {nd }}$ and $29^{\text {th }}$ and May $6^{\text {th }}$, the genotype did not significantly affect the number of $C$. napi larvae $(H(7, N=32)=6.202, P=$ 0.516); $(H(7, N=32)=12.997, P=0.072) ;(H(7, N=32)=11.412, P=0.122)$, respectively (Fig. 6 and Table 6). On May $13^{\text {th }}$, the number of larvae differed significantly between genotypes $\left(F_{7}, 24=4.350, P=0.003\right)$. The resynthesized line S30 showed a significantly lower number of $C$. napi larvae compared to the cultivar Sollux and resynthesized line H30 (Fig. 6 and Table 6). On May $13^{\text {th }}$, an average peak of larval infestation of C. napi was reached (Table 6). On this sampling date, $C$. napi larvae began to leave the plant for pupation in soil (Fig. 6). On May 22 ${ }^{\text {nd }}$, the number of larvae significantly differed between genotypes $\left(F_{7}, 24=23.404, P=0.001\right)$. S30 showed a significantly lower number of larvae compared to the cultivars Sollux and Mendel and H30 (Fig. 6 and Table 6). 


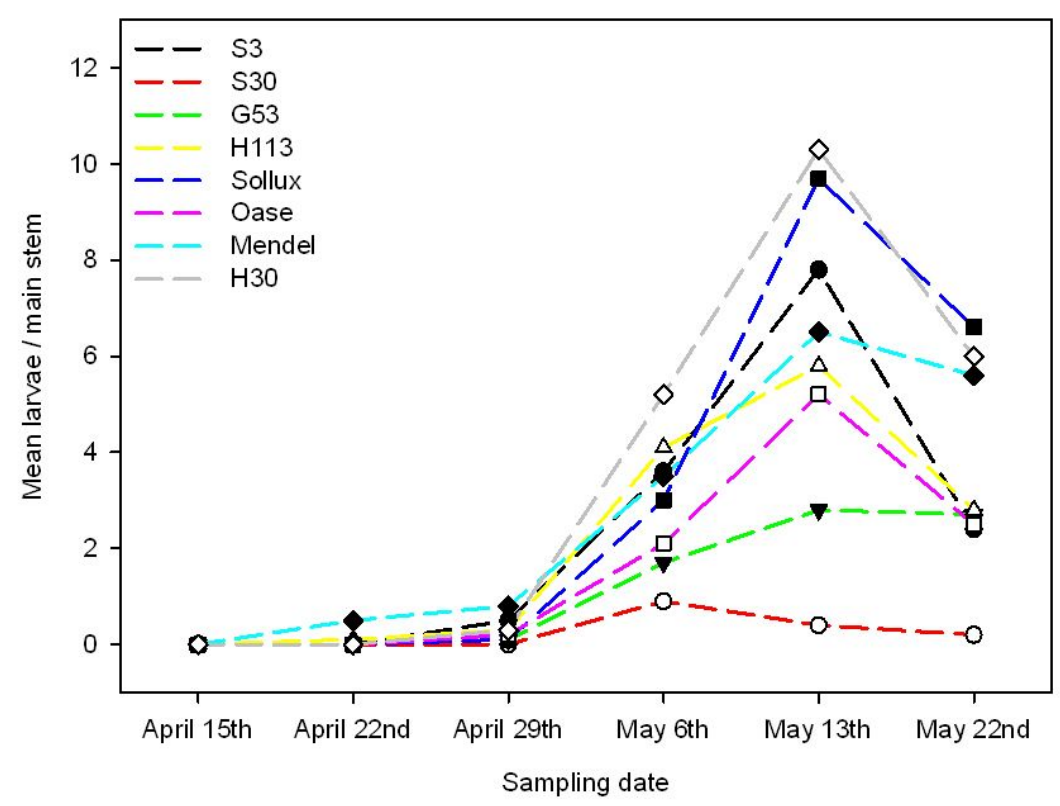

Fig. 6 Number of Ceutorhynchus napi larvae in stems of eight Brassica napus genotypes on six sampling dates. Genotypes were grown in the field experiment in 2012/2013 in four replicates

Table 6 Number of Ceutorhynchus napi larvae in stems of eight Brassica napus genotypes on six sampling dates. Genotypes were grown in the field experiment in 2012/2013. Mean values ( \pm SE) of four replicates. Different letters within each column indicate significant differences between genotypes, $P \leq 0.05$. Number of larvae on May $13^{\text {th }}$, Bonferroni Test; Number of larvae on May $22^{\text {nd }}$, Kruskal-Wallis Test

\begin{tabular}{llllllll}
\hline \multicolumn{7}{c}{ Mean no. larvae / main stem \pm SE } \\
Genotype & ${\text { April } 15^{\text {th }}}^{\text {April } 22^{\text {nd }}}$ & ${\text { April } 29^{\text {th }}}^{\text {th }}$ & May $^{\text {th }}$ & ${\text { May } 13^{\text {th }}}$ May 22 $^{\text {nd }}$ & Mean \\
\hline S3 & 0.0 & $0.00 \pm 0.00$ & $0.45 \pm 0.26$ & $3.55 \pm 1.22$ & $7.80 \pm 1.09 \mathrm{ab}$ & $2.38 \pm 0.50 \mathrm{ab}$ & 2.36 \\
S30 & 0.0 & $0.00 \pm 0.00$ & $0.00 \pm 0.00$ & $0.85 \pm 0.66$ & $0.40 \pm 0.27 \mathrm{~b}$ & $0.18 \pm 0.06 \mathrm{~b}$ & 0.24 \\
G53 & 0.0 & $0.00 \pm 0.00$ & $0.05 \pm 0.05$ & $1.70 \pm 0.77$ & $2.80 \pm 1.11 \mathrm{ab}$ & $2.68 \pm 0.43 \mathrm{ab}$ & 1.21 \\
H113 & 0.0 & $0.10 \pm 0.10$ & $0.30 \pm 0.17$ & $4.10 \pm 1.25$ & $5.80 \pm 1.30 \mathrm{ab}$ & $2.80 \pm 0.50 \mathrm{ab}$ & 2.18 \\
H30 & 0.0 & $0.00 \pm 0.00$ & $0.30 \pm 0.19$ & $5.15 \pm 0.89$ & $10.25 \pm 3.07 \mathrm{a}$ & $6.00 \pm 0.97 \mathrm{a}$ & 3.62 \\
Sollux & 0.0 & $0.00 \pm 0.00$ & $0.10 \pm 0.10$ & $2.95 \pm 0.39$ & $9.70 \pm 1.75 \mathrm{a}$ & $6.58 \pm 0.58 \mathrm{a}$ & 3.22 \\
Oase & 0.0 & $0.00 \pm 0.00$ & $0.20 \pm 0.12$ & $2.10 \pm 0.62$ & $5.15 \pm 1.39 \mathrm{ab}$ & $2.48 \pm 0.66 \mathrm{ab}$ & 1.66 \\
Mendel & 0.0 & $0.05 \pm 0.05$ & $0.80 \pm 0.35$ & $3.50 \pm 1.17$ & $6.50 \pm 1.35 \mathrm{ab}$ & $5.63 \pm 0.99 \mathrm{a}$ & 2.75 \\
\hline Mean & 0.0 & 0.02 & 0.28 & 2.99 & 6.05 & 3.59 & 2.16 \\
\hline
\end{tabular}

The egg or larval mortality was reflected by the larvae:egg ratio. Overall, the genotype had no effect on the ratio between the number of larvae and eggs of $C$. napi $(H(7, N=32)=$ 6.980, $P=0.431$ ) (Table 7). 
Table 7 Ratio between the number of Ceutorhynchus napi larvae in main stems of samples on May $13^{\text {th }}$ and number of eggs deposited by C. napi into main stems of samples on April $29^{\text {th }}$ of eight Brassica napus genotypes. Mean values ( \pm SE) of four replicates. Genotypes were grown in the field experiment in 2012/2013

\begin{tabular}{ll}
\hline Genotype & Larvae : egg ratio \\
\hline S3 & $1.73 \pm 0.30$ \\
S30 & $0.78 \pm 0.46$ \\
G53 & $1.15 \pm 0.45$ \\
H113 & $0.87 \pm 0.15$ \\
H30 & $1.60 \pm 0.30$ \\
Sollux & $0.88 \pm 0.10$ \\
Oase & $1.16 \pm 0.41$ \\
Mendel & $1.47 \pm 0.51$ \\
\hline
\end{tabular}

The larval development time of $C$. napi was reflected by the larval instar index. The mean larval instar index significantly differed between the genotypes $(H(7, N=32)=19.197$, $P=0.008$ ), ranging from 4.75 (S30) to 36.75 (H30) (Fig. 7). The resynthesized line S30 showed a significantly lower larval instar index compared to the resynthesized line H30 (Fig. 7).

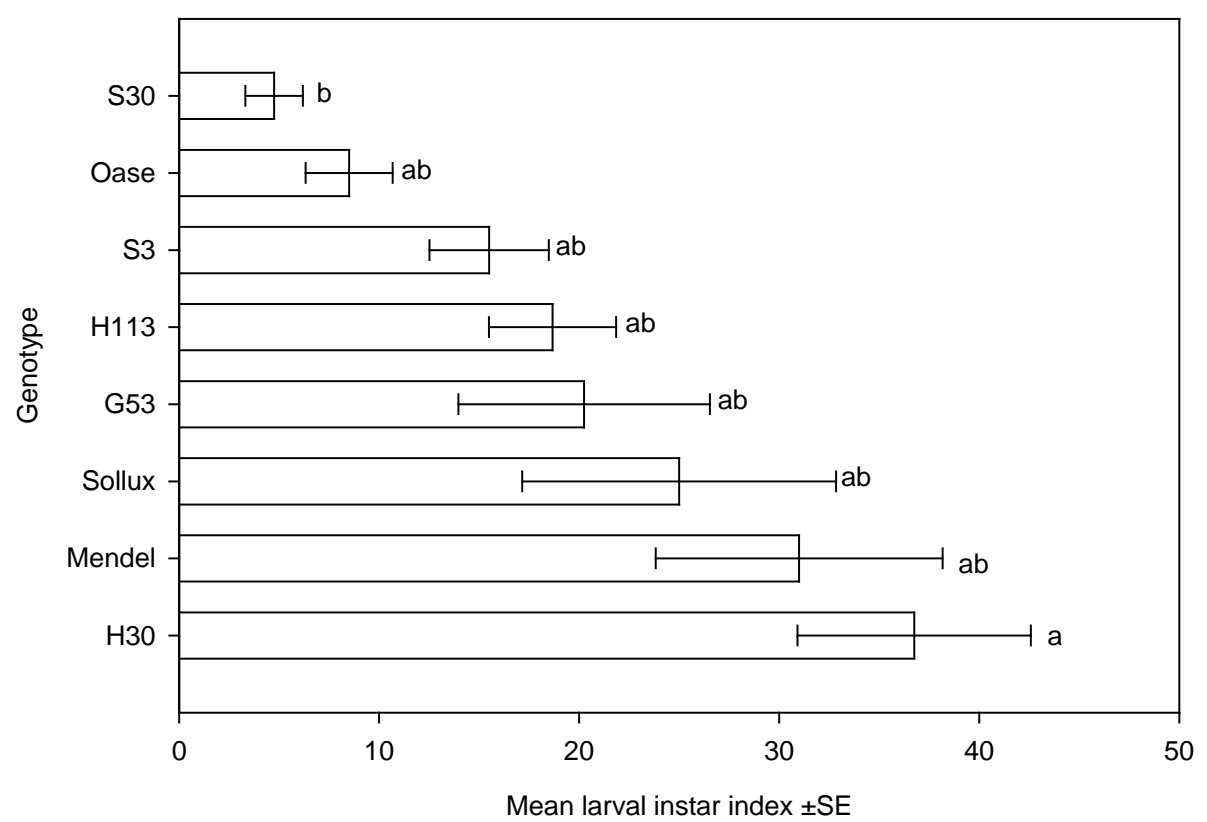

Fig. 7 Instar index of Ceutorhynchus napi larvae developed in main stems of eight Brassica napus genotypes until May $22^{\text {nd }}$. Mean values ( \pm SE) of four replicates. Genotypes were grown in the field experiment in 2012/2013. Different letters indicate significant differences between larval instar indices, Kruskal-Wallis Test, $P$ $\leq 0.05$ 
Over all genotypes, the number of larvae on May $22^{\text {nd }}$ was significantly positively correlated with the larval instar index $(R=0.886, N=32, P=0.003)$.

The mean dry body mass of $2^{\text {nd }}$ larval instars ranged from $0.42 \mathrm{mg}$ (S3) to $0.92 \mathrm{mg}$ (H113). The genotype did not significantly affect the larval dry body mass of the $2^{\text {nd }}$ larval instars $(H(7, N=29)=5.171, P=0.639)$ (Fig. 8). The mean dry body mass of $3^{\text {rd }}$ larval instars ranged from $0.57 \mathrm{mg}$ (Oase) to $2.84 \mathrm{mg}$ (H113). Overall, the genotype did significantly affect on the larval dry body mass of $3^{\text {rd }}$ larval instars $(H(7, N=29)=18.012, P$ $=0.012$ ), but no significant differences between individual genotypes were found (KruskalWallis Test, $P \leq 0.05)$.

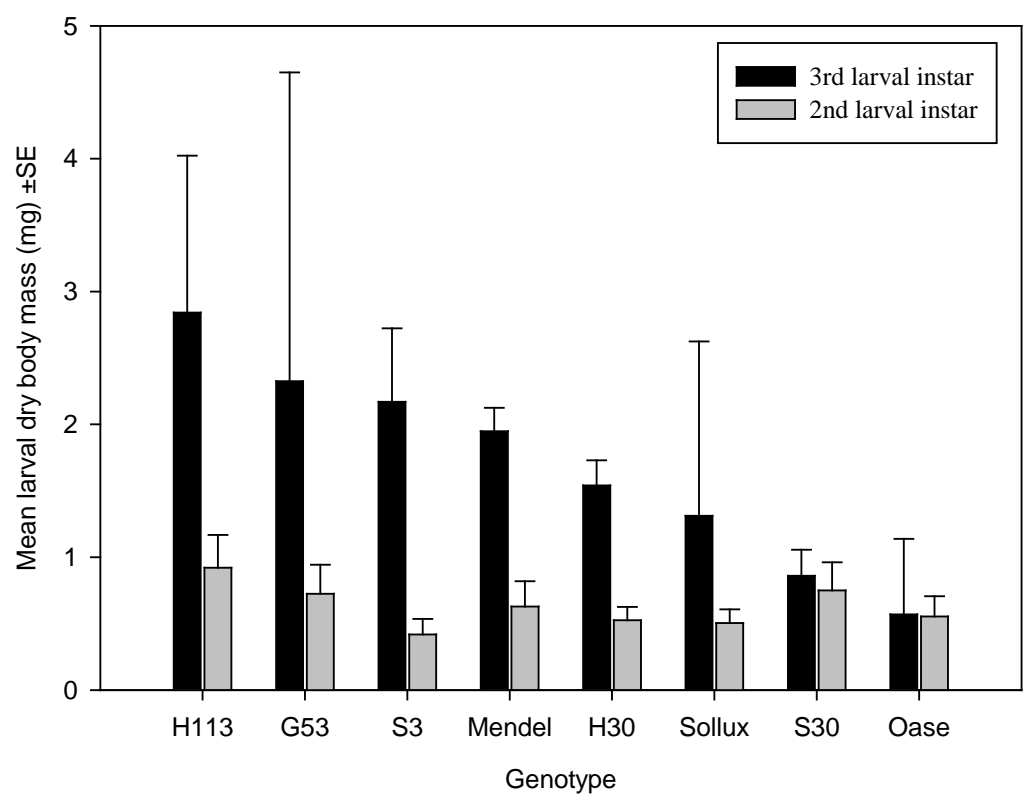

Fig. 8 Dry body mass of $2^{\text {nd }}$ and $3^{\text {rd }}$ instar of Ceutorhynchus napi larvae developed in main stems of eight Brassica napus genotypes until May $22^{\text {nd }}$. Mean values $( \pm \mathrm{SE})$ of three to four replicates. Genotypes were grown in the field experiment in 2012/2013

Performance of C. napi larvae and glucosinolates of infested stems: The multivariate PLS-DA and the associated MANOVA revealed that the glucosinolate profile of infested stems differed between the genotypes (Fig. 9). The score plot explained $72.37 \%$ of the intergenotypic variance. The glucosinolate profiles of H113, H30, S30, G53, Mendel, Oase and Sollux were more close to each other compared to the glucosinolate profile of S3 (Fig. 9). The infested stems of S3 contained the highest mean total glucosinolate content, while H30 contained the lowest mean total glucosinolate content (Table 8). Generally, the mean total glucosinolate contents of infested stems were lower compared to non-infested stems $(N=31$, $d f=60, P=0.000$ ) (Table 8). In all genotypes, contents of individual glucosinolates 
decreased more (approximately 5- to 21-fold decrease) than the content of $4 \mathrm{OH}$ (approximately 0.02- to 0.12-fold decrease) (Table 8). The PLSR analysis revealed no relationship between the number of larvae in samples of May $13^{\text {th }}$ and $22^{\text {nd }}$ and the glucosinolate profile of infested stems (May 13 ${ }^{\text {th }}: 20.07 \%$ variance of number of larvae; May $22^{\text {nd }}: 29.17 \%$ variance of number of larvae). The PSLR also revealed no relationship between the larval instar index and the larval dry body mass of $3^{\text {rd }}$ larval instars and the glucosinolate profile of infested stems (12.01 \% variance of larval instar index, $16.02 \%$ variance of larval dry body mass of $3^{\text {rd }}$ larval instars), respectively.

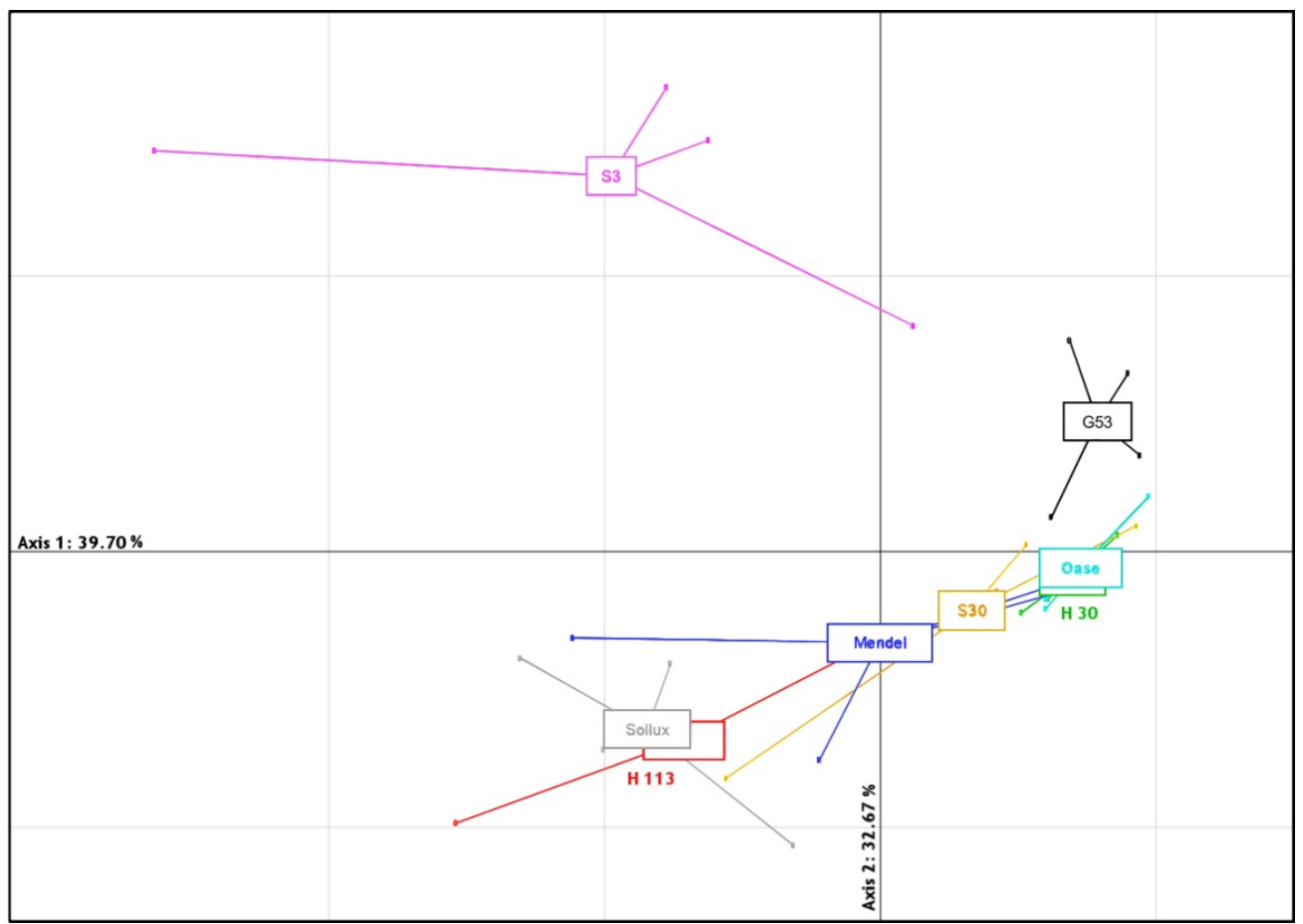

Fig. 9 Score plot of the Partial Least Squares - Discriminant Analysis. PLS-DA analysis performed on the glucosinolate profiles of infested stems of samples on May $24^{\text {th }}$ (score plot explained $72.37 \%$ of the intergenotypic variance; results of the MANOVA testing for the discrimination of genotypes: pseudo- $F_{63,133}=$ 2.472, $P<0.001)$ 
Table 8 Glucosinolate (GSL) contents ( $\mu \mathrm{mol} / \mathrm{g}$ D.W.) of stems of eight Brassica napus genotypes. Genotypes were grown in the field experiment in 2012/2013. Values are means of four replicates. $1=$ non-infested stems (April $\left.17^{\text {th }}\right), 2=$ infested stems (May 24 $\left.4^{\text {th }}\right)$; Aliphatic glucosinolates: PRO $=$ progoitrin, RAA $=$ glucoraphanin, GNL $=$ napoleiferin, ALY = glucoalyssin, GNA = gluconapin, GBN = glucobrassicanapin; Indolyl glucosinolates: GBC = glucobrassicin, 4ME = 4-methoxyglucobrassicin, NEO = neoglucobrassicin, $4 \mathrm{OH}$ = 4-hydroxyglucobrassicin; Aromatic glucosinolate: $\mathrm{NAS}$ = gluconasturtiin

\begin{tabular}{|c|c|c|c|c|c|c|c|c|c|c|c|c|c|c|c|c|}
\hline \multirow[t]{2}{*}{ GSLS } & \multicolumn{2}{|l|}{ H30 } & \multicolumn{2}{|l|}{ S3 } & \multicolumn{2}{|l|}{ S30 } & \multicolumn{2}{|c|}{ Mendel } & \multicolumn{2}{|l|}{ G53 } & \multicolumn{2}{|l|}{ H113 } & \multicolumn{2}{|l|}{ Oase } & \multicolumn{2}{|l|}{ Sollux } \\
\hline & 1 & 2 & 1 & 2 & 1 & 2 & 1 & 2 & 1 & 2 & 1 & 2 & 1 & 2 & 1 & 2 \\
\hline $\begin{array}{l}\text { PRO } \\
\end{array}$ & 6.51 & 0.09 & 30.57 & 8.04 & 6.65 & 0.79 & 6.45 & 0.98 & 13.62 & 0.92 & 17.44 & 2.51 & 6.34 & 0.25 & 18.84 & 1.80 \\
\hline RAA & 0.04 & 0.00 & 0.64 & 0.00 & 0.13 & 0.00 & 0.02 & 0.00 & 0.54 & 0.00 & 0.30 & 0.00 & 0.09 & 0.00 & 0.29 & 0.00 \\
\hline GNL & 0.26 & 0.00 & 0.35 & 0.00 & 0.15 & 0.00 & 0.15 & 0.00 & 0.36 & 0.00 & 0.25 & 0.00 & 0.17 & 0.00 & 0.29 & 0.00 \\
\hline ALY & 6.70 & 0.39 & 2.23 & 0.82 & 4.21 & 1.05 & 2.03 & 0.80 & 3.78 & 0.33 & 7.69 & 2.11 & 3.46 & 0.36 & 9.11 & 1.66 \\
\hline GNA & 0.35 & 0.00 & 6.23 & 0.30 & 0.83 & 0.00 & 2.13 & 0.00 & 3.58 & 0.06 & 0.74 & 0.00 & 1.43 & 0.00 & 2.85 & 0.02 \\
\hline GBN & 4.67 & 0.00 & 5.64 & 0.52 & 7.16 & 0.14 & 8.15 & 0.43 & 13.84 & 0.20 & 7.48 & 0.13 & 7.92 & 0.06 & 21.02 & 0.92 \\
\hline GBC & 3.43 & 0.23 & 1.95 & 0.29 & 1.96 & 0.22 & 3.81 & 0.39 & 2.32 & 0.16 & 4.44 & 0.31 & 2.29 & 0.28 & 4.06 & 0.38 \\
\hline 4ME & 0.50 & 0.10 & 0.27 & 0.12 & 0.33 & 0.10 & 0.35 & 0.08 & 0.27 & 0.08 & 0.24 & 0.11 & 0.29 & 0.06 & 0.51 & 0.21 \\
\hline NEO & 2.28 & 0.27 & 0.68 & 0.20 & 1.24 & 0.30 & 2.00 & 0.39 & 1.89 & 0.09 & 2.62 & 0.74 & 0.97 & 0.27 & 2.66 & 0.47 \\
\hline $4 \mathrm{OH}$ & 0.13 & 0.11 & 0.13 & 0.13 & 0.17 & 0.14 & 0.15 & 0.10 & 0.07 & 0.08 & 0.31 & 0.34 & 0.23 & 0.11 & 0.19 & 0.12 \\
\hline NAS & 0.59 & 0.00 & 1.43 & 0.50 & 0.24 & 0.10 & 0.72 & 0.30 & 1.20 & 0.02 & 2.88 & 0.88 & 0.69 & 0.00 & 2.03 & 0.23 \\
\hline Total & 25.46 & 1.19 & 50.12 & 10.92 & 23.07 & 2.84 & 25.96 & 3.47 & 41.47 & 1.94 & 44.39 & 7.13 & 23.88 & 1.39 & 61.85 & 5.81 \\
\hline
\end{tabular}


Chapter III

Laboratory experiment

Susceptibility to oviposition by C. napi: The mean number of eggs deposited into main stem in no-choice experiment ranged from 0.56 eggs per main stem (S30) to 10.20 eggs per main stem (H30) (Fig. 10). The number of eggs differed significantly between genotypes ( $H$ $(7, N=75)=25.924, P=0.001)($ Fig. 10$)$. The number of eggs in the resynthesized line S30 was significantly lower compared to the cultivar Oase.

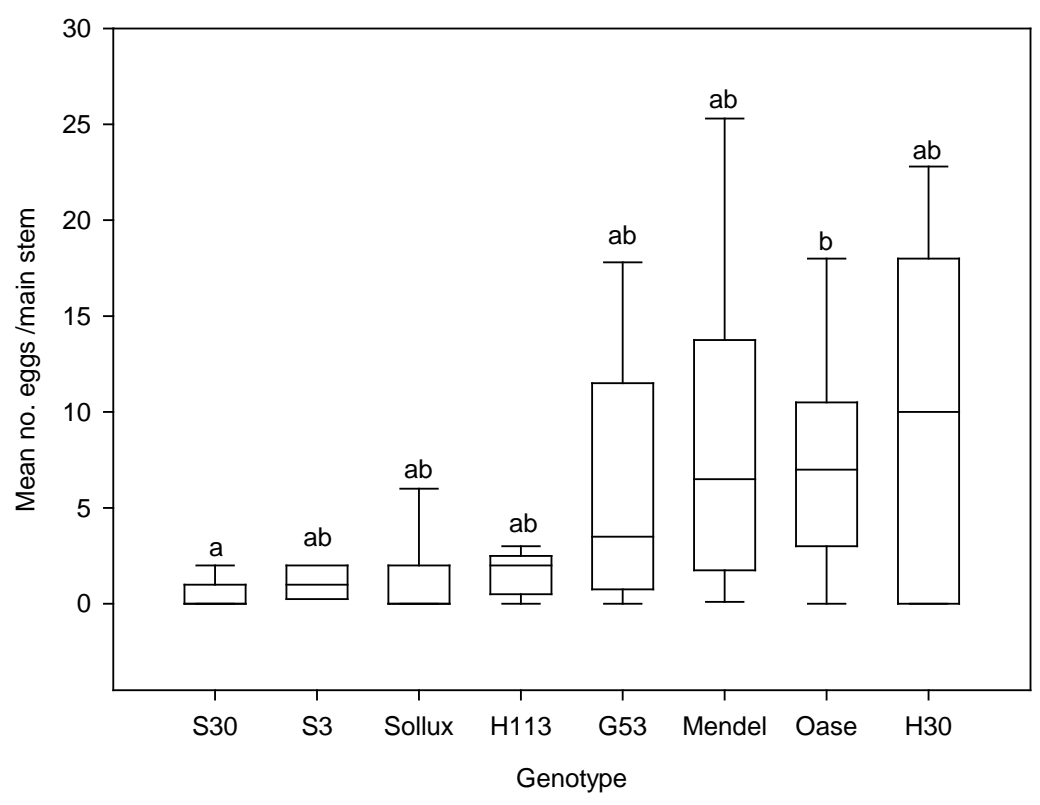

Fig. 10 Number of eggs deposited by Ceutorhynchus napi into stems of eight Brassica napus genotypes grown in the laboratory experiment. The boxes encode the median and the interquartile range $\left(25^{\text {th }}-75^{\text {th }}\right.$ percentiles $)$ of eight to ten replicated plants. Different letters indicate significant differences between genotypes, Kruskal-Wallis Test, $P \leq 0.05$

\section{Discussion}

Field experiment

Susceptibility to oviposition by C. napi and morphological plant traits and plant nutrients: The results of our study revealed considerable variation in infestation levels of $C$. napi between the tested genotypes. In the resynthesized line S30, the number of eggs and larvae was on a very low level during the entire infestation period of C. napi. At all sampling dates S30 contained the lowest number of eggs. The low number of eggs deposited by C. napi into main stems of S30 indicated antixenosis resistance in this genotype. Similar results obtained in semi-field and open field experiments confirmed the low level of infestation of S30 (chapter II and chapter IV). 
Plant growth stages and the length of plant stems are known to have an influence on the oviposition preference of C. napi (Lerin 1993; Buechi 1996). Buechi (1996) found that plants with stem length exceeding $22 \mathrm{~cm}$ were less preferred for egg-laying by females. The $\mathrm{BBCH}$ growth stage of the tested genotypes, which was assessed at the beginning of the oviposition period, had no effect on the number of eggs in samples of April $29^{\text {th }}$ and May $6^{\text {th }}$. Even though the growth stage of S30 and Oase was advanced (BBCH stage 51), only S30 showed a significantly lower number of eggs than Sollux, while the number of eggs in Oase did not differ from Sollux. On April $29^{\text {th }}$, the number of eggs was significantly negative dependent upon the length of the stems on April $22^{\text {nd }}$. On April $22^{\text {nd }}$, the stem length of the resynthesized lines S30, G53 and S3 and the cultivars Oase and Mendel was longer than 22 $\mathrm{cm}$ and the number of eggs on April $29^{\text {th }}$ was lower than in the resynthesized lines H113 and H30 and the cultivar Sollux. This means, the longer the main stems approximately two weeks after main crop colonization (April $7^{\text {th }}$ ), the less eggs were deposited by C. napi into stems. However, length can vary depending on agroclimatic conditions (Ballanger 1987). Additionally, oilseed rape plants with a stem length longer than $20 \mathrm{~cm}$ are less susceptible to stem splitting (Lerin 1993).

No relationships between the number of eggs in samples of April and May and the stem biomass on April $15^{\text {th }}$ were found. However, in this study the stem biomass was not assessed from plants sampled later during the vegetation period. Plant nutrients such as nitrogen, phosphorus and sulphur have been found to affect plant morphology and biochemical composition, which could affect host suitability for herbivores (Malhi et al. 2005). Blake et al. (2010) reported that an increased content of nitrogen in plants decreased the oviposition by females of $C$. obstrictus in oilseed rape. However, in the present study the nitrogen content of stems at the beginning of the oviposition period of $C$. napi did not significantly differ between the genotypes.

Pith tissue changes in plants induced by egg deposition of C. napi: Plant responses to egg deposition by herbivorous insect into stems can result in changes in the plant tissue and affect egg development or hatching of larvae (Hilker et al. 2002). According to Deubert (1955) and to Le Pape and Bronner (1987), pith tissue degeneration (gall formation) is caused by the egg of $C$. napi which induces translocation of water and nutrients from the plant tissue towards the egg. The pith tissue degeneration in stems significantly differed between the tested genotypes. However, when the degree of stem pith degeneration was related to the number of deposited eggs, the plant genotype did not affect the degree of degeneration. In contrast, an extensive neoplasma formation in petioles of oilseed rape following oviposition 
by C. pallidactylus may lead to increased mortality of egg batches (Nuss 2004), a plant response to herbivores caused by an increasing cell division in non-meristemic areas (Hilker et al. 2002). A further category of plant response to egg deposition is a hypersensitive reaction (Hilker et al. 2002). However, this was not observed in our study.

Susceptibility to oviposition by C. napi and stem glucosinolates of non-infested stems: In the present study the PLS-DA analysis and the associated MANOVA revealed significant differences between the glucosinolate profiles in non-infested stems of the tested genotypes. Resynthesized lines of oilseed rape can provide important genetic resources for the modification of glucosinolate profiles in leaves and stems (Cleemput and Becker 2012). Glucosinolates have been shown to trigger oviposition of crucifer-feeding insects (Renwick et al. 1992; Van Loon et al. 1992; Chew and Renwick 1995). They are hydrolyzed by the endogenous enzyme myrosinase following cell disruption (Hopkins et al. 2009), while myrosinase is spatially separated from glucosinolates in non-disrupted cells (Mithen 1992, 2001).

In order to determine the effect of glucosinolates on oviposition by $C$. napi the glucosinolate content of non-infested stems was analyzed at the beginning of the oviposition period. PLSR analysis revealed that the number of $C$. napi eggs in samples of April $29^{\text {th }}$ was positively dependent upon the content of the glucosinolates ALY, GBN and NAS, GBC and NEO. Additionally, univariate data analysis revealed a significantly positive relationship between the number of eggs on April $29^{\text {th }}$ and the content of the stem glucosinolate GBC. Similar results were reported by Giamoustaris and Mithen (1995): reduced levels of leave glucosinolates resulted in lower feeding damage by adult cabbage stem flea beetle (Psylliodes chrysocephala (L.)). Bartlet et al. (1994) reported that feeding by P. chrysocephala was stimulated by GBC and NAS on artificial medium. In other studies, oviposition by Delia radicum correlated positively with NAS (Tansey and Dosdall 2011) and GBC (Roessingh et al. 1992). Oviposition by D. radicum (Roessingh et al. 1992) and chemosensory responses of turnip root fly (Delia floralis (Fall.)) were also stimulated by GBN (Simmonds et al. 1994). In a laboratory experiment, Meier (unpubl. MSc thesis, Goettingen 2013) found a positive correlation between the number of eggs laid by the pollen beetle (Meligethes aeneus (F.)) into buds of different $B$. napus genotypes and the content of NEO. There is little information in the literature about the effect of the aliphatic ALY on behavioral responses of crucifer-feeding insects. Huang and Renwick (1994) reported that oviposition by the green-veined white butterfly (Pieris napi (L.)) was strongly stimulated by aliphatic glucosinolates. In our study, PLSR analysis studying the relationship between the number of $C$. napi eggs and the 
glucosinolate profile of non-infested stems revealed a positive relationship only in plant samples of April $29^{\text {th }}$.

Performance of C. napi and stem glucosinolates of infested stems: In the present study the PLS-DA analysis and the associated MANOVA showed significant differences between the glucosinolate profiles of infested stems of the tested genotypes. The glucosinolate content of infested stems was significantly lower compared to non-infested stems. In brassicaceous plants the glucosinolate content was found to be altered by herbivory (Bodnaryk 1992; Bartlet et al. 1999). Therefore, glucosinolates of infested stems were analyzed to estimate their effect on larval infestation and performance of C. napi. However, no relationship between larval performance and the glucosinolate profiles of infested stems was found. In contrast, Ulmer and Dosdall (2006) found that high levels of specific glucosinolates are associated with a reduced larval weight of $C$. obstrictus.

Performance of $\mathrm{C}$. napi larvae: The low number of $C$. napi larvae in the resynthesized line S30 may result from reduced egg-deposition by females. In studies by Eickermann (2011), the number of C. pallidactylus larvae in S30 was not significantly different to larval numbers in other oilseed rape genotypes. The duration of larval development in the tested genotypes was reflected by the larval instar index. In S30, which showed the lowest number of eggs and larvae during the entire infestation period, as shown by the low proportion of L3 larvae the larval development was delayed, while in H30, at high levels of larval infestation, the proportion of L3 larvae and larval instar index were significantly higher. The delayed larval development in S30 indicated antibiosis resistance in this line. Antibiosis affects herbivore performance and may result in prolonged development, reduced weight or increased mortality (Sarfraz et al. 2006). The number of larvae per plant was significantly positive correlated with the larval instar index. Therefore, there was no indication of intraspecific competition between the larvae at moderate levels of infestation.

The plant content of primary nutrients has been found to affect larval performance of herbivores on oilseed rape (Dosdall and Moisey 2004; Sarfraz et al. 2010). Overall, the nitrogen and carbon content and the $\mathrm{C}: \mathrm{N}$ ratio of stems did not significantly differ between the genotypes. The nitrogen content of plants can change with increasing growth and season (Mattson 1980). High nitrogen contents occur in young and actively growing plant tissues while nitrogen content is lower in older tissues (Mattson 1980). 
Chapter III

Laboratory experiment

To validate the low number of eggs deposited by $C$. napi females into stems of the resynthesized line S30 in the open field, a no-choice laboratory experiment was conducted. As under open field conditions, the resynthesized line S30 contained a very low number of eggs in the laboratory, while the resynthesized line H30 contained the highest number of eggs in the laboratory, but intermediate egg numbers in the open field. The cultivar Sollux which showed the highest number of eggs in the open field contained a comparatively low number of eggs in the laboratory. The results of the laboratory experiment confirmed further evidence that the length of the stem was not a key plant trait affecting host plant acceptance, because all females used in the laboratory oviposition experiment were supplied with the same length of stems of the tested genotypes.

Overall, the results of this study showed that the oilseed rape genotype had a significant influence on oviposition and larval performance of $C$. napi. The resynthesized line S30 which showed a very low infestation might provide a potential source for breeding of oilseed rape cultivars with resistance to $C$. napi. Specific glucosinolates can play a major role in host acceptance and oviposition by females, while these secondary metabolites were not closely associated with larval infestation and larval performance. Also, further investigations are needed to determine the potential effect of chemical traits such as volatile isothiocyanates on host location of C. napi.

\section{Acknowledgements}

I would like to thank Prof. Dr. H. C. Becker for providing seeds of rare genotypes, $\mathrm{H}$. Brandes, B. Olberg and U. Ammermann for glucosinolate analyses (Georg-August University) and M. Hervé for providing multivariate statistical macro and further assistance (INRA, France). I would also like to thank the technical staff in laboratory, greenhouse and in the fields: D. Mennerich, E. Hodyl, M. Knobel, H. Reintke, G. Miotke and all student research assistants.

The study was funded by German Federal Ministry of Food, Agriculture and Consumer Protection (BMELV) and the Board of support for Private Plant Breeding in Germany (GFP). 
Chapter III

\section{References}

Alford DV, Nilsson C, Ulber B (2003) Insect pests of oilseed rape crops. In: DV Alford (Eds.), Biocontrol of oilseed rape pests. Blackwell Science Ltd., Oxford, pp 9-42.

Ali JG, Agrawal AA (2012) Specialist versus generalist insect herbivores and plant defense. Trends in Plant Science 17:293-302.

Awmack CS, Leather SR (2002) Host plant quality and fecundity in herbivorous insects. Annual Review of Entomology 47:817-844.

Ballanger Y (1987) Nuisibilité du charancon de la tige du colza (Ceutorrhynchus napi Gyll.). Phytoma 384:35-37.

Barker E, Rayens W (2003) Partial least squares for discrimination. Journal of Chemometrics $17: 166-173$.

Bartlet E, Kiddle G, Williams I, Wallsgrove R (1999) Wound-induced increases in the glucosinolate content of oilseed rape and their effect on subsequent herbivory by a crucifer specialist. Entomologia Experimentalis et Applicata 91:163-167.

Bartlet E, Parsons D, Williams IH, Clark SJ (1994) The influence of glucosinolates and sugars on feeding by the cabbage stem flea beetle, Psylliodes chrysocephala. Entomologia Experimentalis et Applicata 73:77-83.

Blake A, Dosdall L, Keddie B (2010) Plant nutrients and the spatiotemporal distribution dynamics of Ceutorhynchus obstrictus (Coleoptera: Curculionidae) and its parasitoids. Environmental Entomology 39:1195-1205.

Bodnaryk RP (1992) Effects of wounding on glucosinolates in the cotyledons of oilseed rape and mustard. Phytochemistry 31:2671-2677.

Buechi R (1988) Neue Bekaempfungsschwelle fuer den Rapsstengelruessler Ceutorhynchus napi Gyll. Mitteilungen der Schweizerischen Landwirtschaft 36:110-117.

Buechi R (1996) Eiablage des Rapsstengelruesslers Ceutorhynchus napi Gyll., in Abhaengigkeit der Stengellaenge bei verschiedenen Rapssorten. Anzeiger fuer Schaedlingskunde, Pflanzenschutz, Umweltschutz 69:136-139.

Cárcamo H, Olfert O, Dosdall L, Herle C, Beres B, Soroka J (2007) Resistance to cabbage seedpod weevil among selected Brassicaceae germplasm. The Canadian Entomologist 139:658-669.

Chen Y-Z, Lin L, Wang C-W, Yeh C-C, Hwang S-Y (2004) Response of two Pieris (Lepidoptera: Pieridae) species to fertilization of a host plant. Zoological Studies 43:778-786. 
Chew F, Renwick J (1995) Host plant choice in Pieris butterflies. In: RT Carde and WJ Bell (Eds.), Chemical Ecology of Insects 2. Chapman and Hall, New York, Victoria, Scarborough, Col. Polanco, pp 214-238.

Cleemput S, Becker HC (2012) Genetic variation in leaf and stem glucosinolates in resynthesized lines of winter rapeseed (Brassica napus L.). Genetic Resources and Crop Evolution 59:539-546.

Dechert G, Ulber B (2004) Interactions between the stem-mining weevils Ceutorhynchus napi Gyll. and Ceutorhynchus pallidactylus (Marsh.) (Coleoptera: Curculionidae) in oilseed rape. Agricultural and Forest Entomology 6:193-198.

Deubert K-H (1952) Ueber das durch die Eiablage von Ceutorrhynchus napi Gyll. (Col. Curc.) verursachte histologische Schadbild an Winterraps. Wissenschaftliche Zeitschrift der Martin-Luther-Universitaet Halle-Wittenberg 2:203-205.

Deubert K-H (1955) Beitraege zu den Beziehungen zwischen Ceutorrhynchus napi Gyll. (Col. Curc.) und Winterraps hinsichtlich der Gallenbildung mit Ovarienuntersuchungen an verschiedenen Ceutorrhynchus-Arten. Wissenschaftliche Zeitschrift der Martin-Luther-Universitaet Halle-Wittenberg 5:909-932.

Diederichsen E, Sacristan M (1991) Resynthesis of amphidiploid Brassica species and their clubroot disease reaction. Proc Rapeseed Cong, Saskatoon, Canada, 9-11 July 1991, 1: 274-279.

Dosdall LM, Moisey DW (2004) Developmental biology of the cabbage seedpod weevil, Ceutorhynchus obstrictus (Coleoptera: Curculionidae), in spring canola, Brassica napus, in western Canada. Annals of the Entomological Society of America 97:458465.

Dosse G (1951) Der grosse Kohltriebruessler Ceuthorrhynchus napi Gyll. Biologie, Schadenauftreten und Bekaempfung unter besonderer Beruecksichtigung der "Gallbildung" an Kohlpflanzen: Mit 41 Abb.. Zeitschrift fuer Angewandte Entomologie 32:32-566.

Eickermann M (2011) Resynthesized lines and cultivars of Brassica napus L. provide sources of resistance to the cabbage stem weevil (Ceutorhynchus pallidactylus (Mrsh.)). Bulletin of Entomological Research 101:287-294.

Feeny P (1977) Defensive ecology of the cruciferae. Annals of the Missouri Botanical Garden 64:221-234. 
Friedt W, Luehs W, Mueller M, Ordon F (2003) Utility of winter oilseed rape (Brassica napus L.) cultivars and new breeding lines for low-input cropping systems. Pflanzenbauwissenschaften 7:49-55.

Geladi P, Kowalski B (1986) Partial least squares regression: A tutorial. Analytica Chimica Acta 185:1-17.

Giamoustaris A, Mithen R (1995) The effect of modifying the glucosinolate content of leaves of oilseed rape (Brassica napus ssp. oleifera) on its interaction with specialist and generalist pests. Annals of Applied Biology 126:347-363.

Girke A (2002) Neue Genpools aus resynthetisiertem Raps (Brassica napus L.) fuer die Hybridzuechtung. Dissertation, Georg-August Universitaet, Goettingen.

Girke A, Schierholt A, Becker HC (2012). Extending the rapeseed genepool with resynthesized Brassica napus L. I: genetic diversity. Genetic Resources and Crop Evolution 59:1441-1447.

Guenthart E (1949) Beitraege zur Lebensweise und Bekaempfung von Ceutorrhynchus quadridens Panz. und Ceutorrhynchus napi Gyll. mit Beobachtungen an weiteren Kohl- und Rapsschaedlingen. Mitteilungen der Schweizerischen Entomologischen Gesellschaft 22:441-591.

Hilker M, Fatouros NE (2014) Plant responses to insect egg deposition. Annual Review of Entomology 60:493-515.

Hilker M, Rohfritsch O, Meiners T (2002) The plant's response towards insect egg deposition. In: M Hilker and T Meiners (Eds.), Chemoecology of insect eggs and egg deposition. Blackwell, Berlin, Vienna, pp 205-233.

Hopkins RJ, van Dam NM, van Loon JJA (2009) Role of glucosinolates in insect-plant relationships and multitrophic interactions. Annual Review of Entomology 54:57-83.

Huang X, Renwick J (1994) Relative activities of glucosinolates as oviposition stimulants for Pieris rapae and P. napi oleracea. Journal of Chemical Ecology 20:1025-1037.

Kurtz B, Karlovsky P, Vidal S (2010) Interaction between western corn rootworm (Coleoptera: Chrysomelidae) larvae and root-infecting Fusarium verticillioides. Environmental Entomology 39:1532-1538.

Lancashire PD, Bleiholder H, Boom T, Langelueddeke P, Stauss R, Weber E, Witzenberger A (1991) A uniform decimal code for growth stages of crops and weeds. Annals of Applied Biology 119:561-601. 
Le Pape H, Bronner R (1987) The effects of Ceutorhynchus napi (Curculionidae, Coleoptera) on stem tissue of Brassica napus var. oleifera. In: V Labeyrie, G Fabres and D Lachaise (Eds.), Insect-plants. Dr W Junk, Dordrecht, pp 207-212.

Lerin J (1993) Influence of the growth rate of oilseed rape on the splitting of the stem after an attack of Ceutorhynchus napi Gyll. IOBC WPRS BULLETIN 16 (9):160-163.

Malhi SS, Schoenau JJ, Grant CA (2005) A review of sulphur fertilizer management for optimum yield and quality of canola in the Canadian Great Plains. Canadian Journal of Plant Science 85:297-307.

Mattson WJ (1980) Herbivory in relation to plant nitrogen content. Annual Review of Ecology and Systematics 11:119-161.

Mithen R (1992) Leaf glucosinolate profiles and their relationship to pest and disease resistance in oilseed rape. Euphytica 63:71-83.

Mithen R (2001) Glucosinolates-biochemistry, genetics and biological activity. Plant Growth Regulation 34:91-103.

Mrowczynski M (1998) Studies on pest damage of cultivars and lines of winter oilseed rape. IOBC WPRS BULLETIN 21 (5):153-154.

Nuss H (2004) Einfluss der Pflanzedichte und -architektur auf Abundanz und innnerpflanzliche Verteilung staengelminierender Schadinsekten in Winterraps. Dissertation, Georg-August Universitaet, Goettingen.

Olsson G, Ellerstrom S, Tsunoda S, Hinata K, Gomez-Campo C (1980) Polyploidy breeding in Europe. In: S Tsunoda, K Hinata and C Gomez-Canpo (Eds.), Brassica crops and wild allies. Scientific Society Press, Tokyo, pp 167-190.

Renwick JAA (2002) The chemical world of crucivores: lures, treats and traps. Entomologia Experimentalis et Applicata 104:35-42.

Renwick JAA, Radke CD, Sachdev-Gupta K, Staedler E (1992) Leaf surface chemicals stimulating oviposition by Pieris rapae (Lepidoptera: Pieridae) on cabbage. Chemoecology 3:33-38.

Roessingh P, Staedler E, Fenwick GR, Lewis JA, Nielsen JK, Hurter J, Ramp T (1992) Oviposition and tarsal chemoreceptors of the cabbage root fly are stimulated by glucosinolates and host plant extracts. Entomologia Experimentalis et Applicata 65:267-282.

Rygulla W, Snowdon R, Eynck C, Koopmann B, von Tiedemann A, Luehs W, Friedt W (2007) Broadening the genetic basis of Verticillium longisporum resistance in Brassica napus by interspecific hybridization. Phytopathology 97:1391-1396. 
Sarfraz M, Dosdall L, Keddie B (2006) Diamond-back moth - host plant interactions: implications for pest management. Crop Protection 25:625-639.

Sarfraz RM, Dosdall LM, Blake AJ, Keddie BA (2010) Leaf nutrient levels and the spatiotemporal distributions of Plutella xylostella and its larval parasitoids Diadegma insulare and Microplitis plutellae in canola. BioControl 55:229-244.

Scherf H (1964) Die Entwicklungsstadien der mitteleuropaeischen Curculioniden (Morphologie, Bionomie, Oekologie). Waldemar Kramer, Frankfurt.

Schoonhoven LM, van Loon JJA, Dicke M (2005) Insect-plant biology. Oxford University Press, Oxford.

Seyis F, Friedt W, Luehs W (2001) Resynthese-Raps (Brassica napus L.) als genetische Ressource fuer die Qualitaets-und Ertragszuechtung. Schriften zu Genetischen Ressourcen 16:91-112.

Siemens DH, Mitchelolds T (1996) Glucosinolates and herbivory by specialists (Coleoptera: Chrysomelidae, Lepidoptera: Plutellidae): consequences of concentration and induced resistance. Environmental Entomology 25:1344-1353.

Simmonds MSJ, Blaney WM, Mithen R, Birch ANE, Lewis J (1994) Behavioural and chemosensory responses of the turnip root fly (Delia floralis) to glucosinolates. Entomologia Experimentalis et Applicata 71:41-57.

Tansey JA, Dosdall LM (2011) Differential responses by some insect pests to novel insectresistant Brassica napus L.. Proc Intern Rapeseed Cong, Prague, Czech Republic, 5-9 July 2011, CD-ROM.

Thieme T, Heimbach U, Mueller A (2010) Chemical control of insect pests and insecticide resistance in oilseed rape. In: IH Williams (Eds.), Biocontrol-based integrated management of oilseed rape pests. Springer Science and Business Media B.V., Dordrecht, Heidelberg, London, New York, pp 313-336.

Thies W (1977) Analysis of glucosinolates in seeds of rapeseed (Brassica napus L.): Concentration of glucosinolates by ion exchanges. Zeitschrift fuer Pflanzenzuechtung 79:331-335.

Ulmer BJ, Dosdall LM (2006) Glucosinolate profile and oviposition behavior in relation to the susceptibilities of Brassicaceae to the cabbage seedpod weevil. Entomologia Experimentalis et Applicata 121:203-213.

Van Loon JJA, Blaakmeer A, Griepink FC, van Beek TA, Schoonhoven LM, de Groot A (1992) Leaf surface compound from Brassica oleracea (Cruciferae) induces oviposition by Pieris brassicae (Lepidoptera: Pieridae). Chemoecology 3:39-44. 
Chapter III

Waligora D, Krzymanska J (1995) Biological activity of glucosinolates isolated from rape Brassica napus L. to some insects. Proc Rapeseed Cong, Cambridge, United Kingdom, 4-7 July 1995, 9:1022-1024.

Williams IH (2010) The major insect pests of oilseed rape in Europe and their management: an overview. In: IH Williams (Eds.), Biocontrol-based integrated management of oilseed rape pests. Springer Science and Business Media B.V., Dordrecht, Heidelberg, London, New York, pp 1-43. 


\section{CHAPTER IV}

Screening of oilseed rape (Brassica napus L.) genotypes for susceptibility to infestation by rape stem weevil (Ceutorhynchus napi Gyll.) and cabbage stem weevil (Ceutorhynchus pallidactylus (Marsh.))

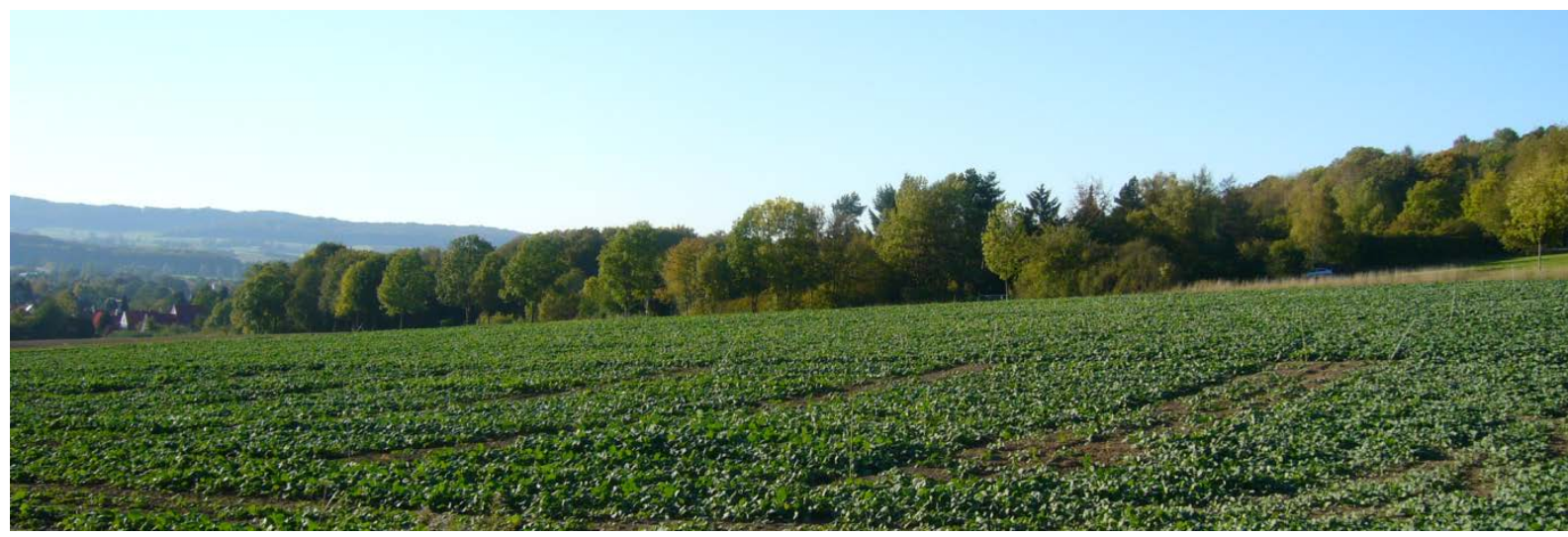




\section{Abstract}

In a 2-year field study (2012 and 2013), we evaluated a large assortment of 30 genotypes of oilseed rape (Brassica napus L.), showing a broad genetic variability, for the susceptibility to the stem-boring weevils, rape stem weevil (Ceutorhynchus napi Gyll.) and cabbage stem weevil (Ceutorhynchus pallidactylus (Marsh.)). The number of eggs deposited by $C$. napi was assessed from plants collected at the beginning of the oviposition period in March 2012. The number of eggs per main stem differed significantly between genotypes. The resynthesized line H113 and the cultivars Sollux and Grizzly contained significantly less eggs compared to the resynthesized line S3. The number of mature larvae of $C$. napi and $C$. pallidactylus was assessed in May 2012 and 2013. In 2012 and 2013, the resynthesized line S30 contained a significantly lower number of $C$. napi larvae compared to the cultivars Mendel (2012), Sollux and Grizzly (2013) and the resynthesized line H10 (2013). The low number of $C$. napi larvae indicated antixenosis and/or antibiosis resistance in S30. The number of $C$. pallidactylus larvae did not significantly differ between genotypes in both years. The larval feeding damage by C. napi and C. pallidactylus within stems was assessed by the stem injury coefficient. In 2013, the resynthesized line S30 showed the lowest stem injury coefficient, while in 2012 the stem injury coefficient did not significantly differ between the genotypes. In 2013, the number of $C$. napi larvae was significantly positive dependent upon stem injury coefficient.

Morphological stem traits, and stem and leave levels of glucosinolates, carbon and nitrogen were assessed as potential mediators of resistance. The number of eggs deposited by C. napi into the main stems was significantly positive dependent upon the length of stems at the beginning of stem elongating. No relationship between the number of $C$. napi larvae in main stems and the length of full-grown stems was found. The carbon content, nitrogen content and $\mathrm{C}: \mathrm{N}$ ratio of stems differed significantly between the genotypes. However, the number of eggs and larvae of $C$. napi were not dependent upon carbon content, nitrogen content and C:N ratio. The stem and leave glucosinolates differed significantly between the tested genotypes. At the beginning of the oviposition period, the number of eggs deposited by C. napi into main stems was significantly positive dependent upon the content of napoleiferin and significantly negative dependent upon the content of glucoalyssin and neoglucobrassicin. In 2012 and 2013, the number of C. napi larvae was not dependent upon the glucosinolate contents of stems. 


\section{Keywords}

Resynthesized lines, glucosinolates, nitrogen, host-plant resistance, oviposition preference, stem-boring weevils, Curculionidae

\section{Introduction}

Rape stem weevil, Ceutorhynchus napi Gyll. (Col., Curculionidae) and cabbage stem weevil, Ceutorhynchus pallidactylus (Marsh.) (Col., Curculionidae) commonly cause economic damage in oilseed rape crops (Brassica napus L.) in Europe (Alford et al. 2003). The life cycle of C. napi has been studied by several authors (Guenthart 1949; Dosse 1951; Deubert 1952, 1955; Schmutterer 1956; Ballanger 1987; Le Pape and Bronner 1987; Lerin 1993). Adult weevils migrate to oilseed rape crops in early spring. In March/April, after two weeks of feeding, females deposit single eggs into elongating stems of oilseed rape plants. Larvae feed within the stem pith tissue. In May/June, the full-grown larvae leave the plant to pupate in soil. Adult weevils overwinter within earthen pupal cocoons. Females pass through an obligate, pre-reproductive diapause before they migrate to new crops the following spring.

In Central European oilseed rape crops, C. pallidactylus often occurs sympatrically with C. napi (Dechert and Ulber 2004). In March/April, adults of C. pallidactylus lay their egg batches into petioles. Neonate larvae feed within the petioles before $2^{\text {nd }}$ instar larvae move into stems to complete their development (Guenthart 1949). Both stem-boring species (C. napi and C. pallidactylus) share the stem pith tissue and avoid interspecific competition. Dechert and Ulber (2004) showed that larvae of C. pallidactylus preferably fed in the lower parts of the stem.

Currently, management of insect pests of oilseed rape is strongly based on synthetic insecticides (Williams 2010; Thieme et al. 2010). Because pyrethroids are primarily used for the control of the main insect pests, selection pressure for resistance is high (Thieme et al. 2010). Between 2007 and 2012, winter oilseed rape in Germany was on average treated with insecticides 2.8 times (Freier et al. 2014). In integrated pest management systems, resistant cultivars are needed to minimize the number of insecticide applications. Preliminary field observations indicated only minor variation in infestation and damage by $C$. napi between different cultivars and lines of oilseed rape (Mrowczynski 1998; Dechert and Ulber 2004). No resistance to infestation by $C$. napi has been found to date within the gene pool of oilseed rape. Therefore, breeding for host plant resistance is a major tool in integrated pest management (Gullan and Cranston 2005) and an important breeding trait in oilseed rape 
(Frauen 2011). A wide genetic variation is required to improve plant breeding with regard to insect pest resistance traits (Snowdon and Friedt 2004; Snowdon 2007; Friedt 2011). Interspecific crossing of the two progenitor species (Brassica oleracea L. and Brassica rapa L) of oilseed rape might have potential for broadening the genetic variation (Olsson et al. 1980; Girke et al. 2012). By developing and testing these resynthesized lines, sources for disease resistance (Diedrichsen and Sacristan 1991; Rygulla et al. 2007) and pest resistance might be detected (Seyis et al. 2001; Eickermann 2011). There are some examples in literature indicating host plant resistance in Brassicaceae to coleopteran species, such as cabbage flea beetle (Phyllotreta nemorum (L.)) (Renwick 2002), mustard leaf beetle (Phaedon cochleariae (F.)) (Uddin et al. 2009), cabbage stem weevil (Eickermann 2011), and cabbage seed weevil (Ceutorhynchus obstrictus (Marsh.)) (Cárcamo et al. 2007; Tansey and Dosdall 2011).

Host plant selection of insects is affected by morphological and metabolic plant traits (Sarfraz et al. 2006). Females of C. napi prefer oilseed rape stems shorter than $22 \mathrm{~cm}$ compared to longer stems for oviposition (Buechi 1996). Larval infestation by C. pallidactylus increases with increasing number of side shoots and leaves on oilseed rape (Eickermann and Ulber 2011). Cabbage root fly (Delia radicum (L.)) preferentially attacks larger cruciferous plants with higher biomass (Mustata and Mustata 2009). Similarly, larval density of cabbage stem flea beetle (Psylliodes chrysocephala (L.)) increases with increasing plant biomass of oilseed rape (Nuss 2004).

Plant metabolics such as glucosinolates play a major role for host acceptance of crucifer-feeding insects (Renwick et al. 1992; Bartlet et al. 1994; Huang and Renwick 1994; Renwick 2002) and trigger oviposition by these insects (Renwick et al. 1992; Van Loon et al. 1992; Chew and Renwick 1995). Glucosinolates are a major group of secondary metabolites in Brassicaceae (Rodman et al. 1996). They are catalyzed by the endogenous enzyme myrosinase following cell disruption (Fenwick and Heaney 1983; Hopkins et al. 2009), while myrosinase is spatially separated from glucosinolates in non-disrupted cells (Mithen 1992, 2001). The presence of glucosinolates in cruciferous plants has also been found to serve as defense compounds against non-specific insects (Feeny 1977). However, even specialist insects are not completely immune to these defense compounds (Ali and Agrawal 2012). Glucosinolates can cause repulsion or deterrence of specialist insect pests in crucifer plants (Waligora and Krzymanska 1995). For instance, high glucosinolate concentrations in leaves of oilseed rape resulted in lower numbers of cabbage aphid (Brevicoryne brassicae (L.)), compared to leaves with lower concentrations (Waligora and Krzymanska 1995). 
Plant nutrients such as nitrogen can affect preference and performance of herbivorous insects (Blake et al. 2010). The plant attractiveness can be modified by the crop nitrogen status (Rusch et al. 2013), thereby affecting pest abundance in the crop (Staley et al. 2010). Fertilization rates of nitrogen can affect host acceptance by females of Pieris spp., which laid more eggs on highly fertilized plants compared to poorly fertilized plants (Chen et al. 2004). The ratio of carbon and nitrogen content of plants has been hypothesized to affect plant susceptibility to leaf-eating insects (Lincoln 1993). It has also been considered as a parameter to explain the performance of herbivorous insects on different host plants (Moeser and Vidal 2004).

To analyze the susceptibility of 30 genotypes of oilseed rape for oviposition and larval infestation by $C$. napi and for larval infestation by $C$. pallidactylus, a large assortment of genetically variable $B$. napus genotypes was assessed. Potential morphological and metabolic plant traits as well as nitrogen and carbon contents of plants were assessed to determine plant resistance mechanisms to both stem-boring species.

\section{Material and Methods}

Year 2011/2012

Field experiment: The first multi-choice field experiment was conducted at the experimental station of Georg-August University (N 51³3’58.8 E 956’55.5). 30 genotypes were sown on August $22^{\text {nd }} 2011$ and grown in a complete randomized block design with four replicated plots $(1.5 \mathrm{~m} \times 7.5 \mathrm{~m})$ of each genotype. These genotypes were selected, because of their broad genetic background according to Girke (2002) and Cleemput and Becker (2012). To avoid border effects, the oilseed rape cultivar Titan was sown in the surrounding plots. Sowing density was 27 seeds $/ \mathrm{m}^{2}$. Natural crop colonization of C. napi and C. pallidactylus was monitored by using four yellow traps $(33.0 \mathrm{~cm} \times 25.0 \mathrm{~cm} \times 7.3 \mathrm{~cm})$, which were located around the experiment (one trap on each margin). To analyze the susceptibility of $B$. napus genotypes to oviposition by $C$. napi females, five randomly selected plants of each plot were sampled on March $26^{\text {th }}$ 2012. Additionally, the BBCH growth stage (Lancashire et al. 1991) and the length of above ground main stems was assessed from these plants. Because of a poor crop establishment in the plots of 11 genotypes only 19 out of $30 \mathrm{~B}$. napus genotypes could be analyzed for oviposition. To analyze resistance of $B$. napus genotypes to larval infestation by both stem-boring species, ten randomly selected plants of each plot were sampled on May $8^{\text {th }}$ 2012 when $2^{\text {nd }}$ instar larvae of $C$. pallidactylus had migrated from petioles into main stems. 
Because of the poor crop establishment in the plots of 7 genotypes only 23 out of $30 \mathrm{~B}$. napus genotypes could be analyzed for larval infestation. Larvae of both stem-boring species were dissected from the main stems under a stereo microscope (Zeiss, Stemi 2000-C). Additionally, the length of full-grown stems and the length of larval feeding tunnels within the stem pith were assessed from these plants. The stem injury coefficient was calculated by the ratio between the length of larval feeding tunnels to the length of the full-grown plant stems (Ferguson et al. 2003).

Year 2012/213

Field experiment: The second multi-choice field experiment was conducted at the experimental station of Georg-August University (N51³3’56.3 E956’49.9). On August $22^{\text {nd }}$ 2012, the same 30 genotypes were sown in the same experimental design as in the first year. To avoid border effects, a mixture of the oilseed rape cultivars Trabant, Dimension and Elektra were sown in surrounding plots. Sowing density was 33 seeds $/ \mathrm{m}^{2}$. Natural crop colonization of C. napi and C. pallidactylus was monitored as described above. To analyze the effects of $\mathrm{BBCH}$ growth stages, biomass and dry biomass of stems on the level of infestation by both stem-boring species, six randomly selected plants of each plot were sampled on April $15^{\text {th }} 2013$ before oviposition by stem-boring species. Stem dry biomass was determined by drying the stems at $60{ }^{\circ} \mathrm{C}$ for three days and $120{ }^{\circ} \mathrm{C}$ for one day. The dry weights of the stems were assessed using a scale (Sartorius TE1502S). To analyze the larval infestation by both weevil species, ten randomly selected plants of each plot were sampled on May $22^{\text {nd }}$ 2013. Only 26 out of 30 B. napus genotypes could be evaluated for larval infestation, because of a low number of plants in the plots of 4 genotypes. The main stems were dissected to assess the number of larvae of both species as described before. Additionally, the length of full-grown main stems and of larval feeding tunnels were evaluated to determine the stem injury coefficient. 
Table 1 Resynthesized lines, cultivars and breeding lines of Brassica napus selected for evaluation of the susceptibility to Ceutorhynchus napi and Ceutorhynchus pallidactylus in field experiments in 2011/2012 and 2012/2013, according to (Girke 2002), Cleemput and Becker (2012) and Rudloff (MSc thesis unpubl., Goettingen 2012). ++ = high contents of erucic acid and glucosinolates in seeds; 00 = no erucic acid and low glucosinolate content in seeds; OP = open-pollinated

\begin{tabular}{|c|c|c|c|}
\hline Genotype & Type & Mother & Father \\
\hline G53 & resynthesized line & B. oleracea convar. capitata var. capitata & B. rapa ssp. nipposinica var. perviridis \\
\hline $\mathrm{H} 10$ & resynthesized line & B. oleracea convar. capitata var. capitata & B. rapa ssp. pekinensis \\
\hline $\mathrm{H} 30$ & resynthesized line & B. rapa ssp. chinensis & B. napus var. pabularia \\
\hline H65 & resynthesized line & B. oleracea convar. capitata var. sabauda & B. rapa ssp. pekinensis \\
\hline H113 & resynthesized line & B. oleracea convar. capitata var. sabauda & B. rapa ssp. pekinensis \\
\hline H149 & resynthesized line & B. oleracea convar. acephala var medullosa & B. rapa ssp. chinensis \\
\hline H231 & resynthesized line & B. oleracea convar. capitata var. capitata & B. rapa ssp. pekinensis \\
\hline H327 & resynthesized line & B. oleracea convar. capitata var. capitata & B. rapa ssp. nipposinica var. perviridis \\
\hline L16 & resynthesized line & B. oleracea convar. botrytis var. alboglabra & B. rapa ssp. pekinensis \\
\hline L122 & resynthesized line & B. oleracea convar. capitata var. sabauda & B. rapa ssp. pekinensis \\
\hline R53 & resynthesized line & B. oleracea convar. acephala var. sabellica & B. rapa ssp. pekinensis \\
\hline R140 & resynthesized line & B. oleracea convar. capitata var. capitata & B. rapa ssp. oleifera \\
\hline S3 & resynthesized line & B. rapa ssp. rapa & B. oleracea convar. acephala var. sabellica \\
\hline S14 & resynthesized line & B. napus pabularia X B. oleracea convar. acephala var. sabellica & B. rapa ssp. oleifera \\
\hline S30 & resynthesized line & B. oleracea convar. capitata var capitata & B. rapa ssp. pekinensis \\
\hline Abukuma natane & $(++)$ OP cultivar & \multicolumn{2}{|c|}{ B. napus var. biennis, Japan } \\
\hline Gaoyou & $(++)$ native breed & \multicolumn{2}{|c|}{ B. napus var. biennis, China } \\
\hline Olimpiade & $(++)$ OP cultivar & \multicolumn{2}{|c|}{ B. napus var. biennis, Italy } \\
\hline Sollux & $(++)$ OP cultivar & \multicolumn{2}{|c|}{ B. napus var. biennis, Germany } \\
\hline DH Mansholt & $(++)$ DH-line & \multicolumn{2}{|c|}{ B. napus var. biennis, Netherlands } \\
\hline Campala & (00) OP cultivar & \multicolumn{2}{|c|}{ B. napus var. biennis, United Kingdom } \\
\hline Express617 & (00) OP cultivar & \multicolumn{2}{|c|}{ B. napus var. biennis, Germany } \\
\hline Grizzly & (00) OP cultivar & \multicolumn{2}{|c|}{ B. napus var. biennis, France } \\
\hline Liropa & (00) OP cultivar & \multicolumn{2}{|c|}{ B. napus var. biennis, Germany } \\
\hline Mendel & (00) hybrid cultivar & \multicolumn{2}{|c|}{ B. napus var. biennis, clubroot resistance, Germany } \\
\hline Oase & (00) OP cultivar & \multicolumn{2}{|c|}{ B. napus var. biennis, Germany } \\
\hline Santana & (00) OP cultivar & \multicolumn{2}{|c|}{ B. napus var. biennis, France } \\
\hline Visby & (00) hybrid cultivar & \multicolumn{2}{|c|}{ B. napus var. biennis, Germany } \\
\hline DH Samourai & (00) DH-line & \multicolumn{2}{|c|}{ B. napus var. biennis, France } \\
\hline Goe1991 & (00) line & \multicolumn{2}{|c|}{ B. napus var. biennis, Goettingen, Germany } \\
\hline
\end{tabular}


Chemical analysis of plants: Five randomly selected stems and leaves (five leaves from top of plants) per plot were sampled for glucosinolate analyses on March $27^{\text {th }} 2012$ and on April $17^{\text {th }}$ 2013, respectively. Glucosinolates could be evaluated only from 23 (2012) and 26 (2013) out of 30 B. napus genotypes, because of the low number of plants in the plots of 7 and 4 genotypes, respectively. The stems and leaves were frozen on dry ice and stored at -20 ${ }^{\circ} \mathrm{C}$. Each sample was freeze-dried for 96 hours and homogenized using a mill (Krups KM 75). Stem and leave glucosinolates were separated and individual compounds were identified and quantified (Thies 1977). Desulfoglucosinolates were extracted as detailed by Cleemput and Becker (2012) and analyzed using Shimadzu Prominence LC20AT series HPLC (Shimadzu Deutschland GmbH) equipped with a Nucleodur 100-3 C18 column (Macherey Nagel). Desulfoglucosinoltes were separated using a water-acetonitrile gradient (solvent A water, solvent B acetonitrile; 0-20 min 1-20\% B; 20-25 min 20\% B; 25-27 min 20 \% B; 27-34 min $1 \% \mathrm{~B})$ at a flow rate of $0.6 \mathrm{ml} / \mathrm{min}$. Retention times of known standards were used to identify desulfoglucosinolates. Concentrations of glucosinolates are expressed in $\mu \mathrm{mol} / \mathrm{g}$ dry weigth (D.W.).

Six randomly selected stems per plot were sampled for analyses of the nitrogen and carbon content on April $15^{\text {th }}$ 2013. Only 26 out of 30 B. napus genotypes could be evaluated for the nitrogen and carbon content. The stems were dried at $60{ }^{\circ} \mathrm{C}$ for three days, milled using a centrifugal mill and analyzed by a CN element analyzer (Vario EL, Fa. Elementar Analysensysteme GmbH, Hanau).

Table 2 Denomination of individual glucosinolates and chemical groups of glucosinolates detected in stems and leaves of the tested Brassica napus genotypes according to Velasco and Becker (2000), Fahey et al. (2001), Halkier and Gershenzon (2006) and Feng et al. (2012)

\begin{tabular}{llll}
\hline Systematic name & Trivial name & Abbreviation & Group \\
\hline 2-hydroxy-3-butenyl & progoitrin & PRO & aliphatic \\
2-hydroxy-4-pentenyl & napoleiferin & GNL & aliphatic \\
5-methylsulphinylpentyl & glucoalyssin & ALY & aliphatic \\
3-butenyl & gluconapin & GNA & aliphatic \\
4-pentenyl & glucobrassicanapin & GBN & aliphatic \\
4-methylsulphinylbutyl & glucoraphanin & RAA & aliphatic \\
4-hydroxy-3-indolylmethyl & 4-hydroxyglucobrassicin & 4OH & indolyl \\
3-indolylmethyl & glucobrassicin & GBC & indolyl \\
4-methoxy-3-indolylmethyl & 4-methoxyglucobrassicin & 4ME & indolyl \\
n-methoxy-3-indolmethyl & neoglucobrassicin & NEO & indolyl \\
2-phenylethyl & gluconasturtiin & NAS & Aromatic \\
\hline
\end{tabular}


Chapter IV

\section{Data analysis}

Univariate data analysis was done using Statistica 10 (StatSoft ${ }^{\circledR}$, Tusla, USA), while multivariate data analysis was conducted using $\mathrm{R}$ 3.0.1. All data was tested for normal distribution with Shapiro-Wilks W Test.

Univariate data analysis: The effects of the plant genotype on the number of eggs deposited by $C$. napi and on the length of stems at the early stage of the oviposition period were analyzed by factorial one-way Kruskal-Wallis variance analysis (KW-ANOVA); the differences among ranks were evaluated by Kruskal-Wallis Test. To analyze the influence of the length of the stem on the oviposition by $C$. napi, linear regression was used. The same model was used to evaluate the influence of the length of the full-grown stem on the oviposition by C. napi. Linear regression was also used to evaluate the relationship between the number of eggs deposited by C. napi and the carbon content, nitrogen content and C:N ratio in stems of genotypes. To analyze the influence of plant metabolic traits on infestation by $C$. napi larvae, linear regression was used to test the effect of individual contents of stem glucosinolates, content of glucosinolate groups, ratios and total glucosinolate content on the number of C. napi larvae in samples of 2012 and 2013. Samples of C. pallidactylus larvae were excluded from the analysis due to non-significant differences in the number of $C$. pallidactylus larvae between genotypes in both years.

Analysis of covariance (ANCOVA) was performed to detect genotype effects on the number of $C$. napi larvae in 2012. Number of $C$. napi larvae was treated as the main factor and the length of the full-grown stem was included as a covariate. To analyze genotype effects on the number of C. napi larvae in 2013 and on the number of C. pallidactylus larvae in 2012 and 2013, KW-ANOVA was performed. The number of C. napi larvae in 2013 and the number of $C$. pallidactylus larvae in 2012 and 2013 were analyzed differently from the number of $C$. napi larvae in 2012, because of non-normal distribution of residuals of $C$. napi larvae in 2013 and C. pallidactylus larvae in 2012 and 2013.

KW-ANOVA was also performed to analyze the genotype effects on the length of the full-grown stems, length of larval feeding tunnels and on the stem injury coefficients in both years. To analyze the influence of the number of $C$. napi larvae in 2013 on the length of fullgrown stems, on the length of larval feeding tunnels and on the stem injury coefficients in 2013, linear regressions were performed. The relationships between the number of $C$. napi larvae in 2012 and the length of full-grown stems, the length of larval feeding tunnels and the stem injury coefficients were not statistically analyzed, because of non-significant differences in the number of $C$. napi larvae between genotypes in 2012. The relationships between the 
number of $C$. pallidactylus larvae and the length of full-grown stems, the length of larval feeding tunnels, the stem injury coefficients and plant nutrients were not statistically analyzed, because of non-significant differences in the number of $C$. pallidactylus larvae between genotypes in both years.

To analyze genotype effects on the biomass, the dry biomass and the content of plant nutrients (carbon content, nitrogen content and C:N ratio) of stems, KW-ANOVA was performed. Percentage values of carbon and nitrogen content were $\arcsin v$ transformed. The relationships between the number of both stem-boring species and the biomass and dry biomass of stems were not statistically analyzed, because of non-significant differences of the biomass and dry biomass between genotypes. The relationships between the stem injury coefficients and the carbon contents, nitrogen contents and $\mathrm{C}: \mathrm{N}$ ratio were not statistically analyzed, because of multi-collinearity of the stem injury coefficient and the number of $C$. napi larvae.

Multivariate data analysis: To test both stems and leaves for between-genotype differences in glucosinolate profiles, Partial Least Squares-Discriminant Analysis (PLS-DA; function 'plsda', package ‘mixOmics'; Barker and Rayens (2003)) was used, and significance of discrimination was tested by multivariate analysis of variance (MANOVA).

Partial Least Squares Regression (PLSR; Geladi and Kowalski (1986)) was applied to investigate the relationship between the glucosinolate profile of stems and the number of $C$. napi eggs and larvae (function 'pls' regression mode, package 'mixOmics'). All data was scaled to unit variance and was mean centered by default in the analysis. When the glucosinolate profiles of stems were related to the number of eggs of C. napi only 19 genotypes were included into the PLS-DA and PLSR analyses, because only 19 genotypes were analyzed for oviposition by $C$. napi in the field experiment (cf. Material and Methods). When the glucosinolate profiles of stems were related to the number of $C$. napi larvae, 23 (2012) and 26 (2013) genotypes were included into the PLS-DA and PLSR analyses, because only 23 (2012) and 26 (2013) genotypes were analyzed for infestation by C. napi larvae in the field experiments, respectively.

PLSR analyses were not applied to analyze the relationships between the glucosinolate profiles of leaves (2012 and 2013) and number of C. pallidactylus larvae (2012 and 2013), because no significant differences in the number of $C$. pallidactylus larvae in main stems were found between the genotypes. PLSR analysis was also not applied to analyze the relationship between the glucosinolate profile of stems (2012) and the stem injury coefficients (2012) because no significant differences in the stem injury coefficients (2012) were found. It was 
Chapter IV

also abstained from analyzing the relationship between the glucosinolate profile of stems (2013) and the stem injury coefficient (2013) with PLSR, because of multi-collinearity of the stem injury coefficient and the number of C. napi in 2013.

\section{Results}

The main crop immigration period of both weevil species into the oilseed rape fields occurred on March $14^{\text {th }}-16^{\text {th }}$ in 2012 and on April $4^{\text {th }}-7^{\text {th }}$ in 2013. In 2012, the mean percentage of main stems of all tested genotypes infested by C. napi larvae was at $96.92 \%$ and in 2013 at $87.81 \%$. In 2012, the mean percentage of main stems of all tested genotypes infested by C. pallidactylus larvae was at $41.98 \%$ and in 2013 at $60.91 \%$.

Susceptibility to oviposition by C. napi: On March $26^{\text {th }} 2012$, at the early stage of the oviposition period, the number of eggs deposited by $C$. napi into the main stem differed significantly between individual genotypes $(H(18, N=76)=53.072, P=0.000)$ (Fig.1). The cultivars Sollux and Grizzly and the resynthesized line H113 contained significantly less eggs compared to the resynthesized line S3 (Fig. 1). Over all tested genotypes 12.2 eggs per main stem were deposited on average by $C$. napi.

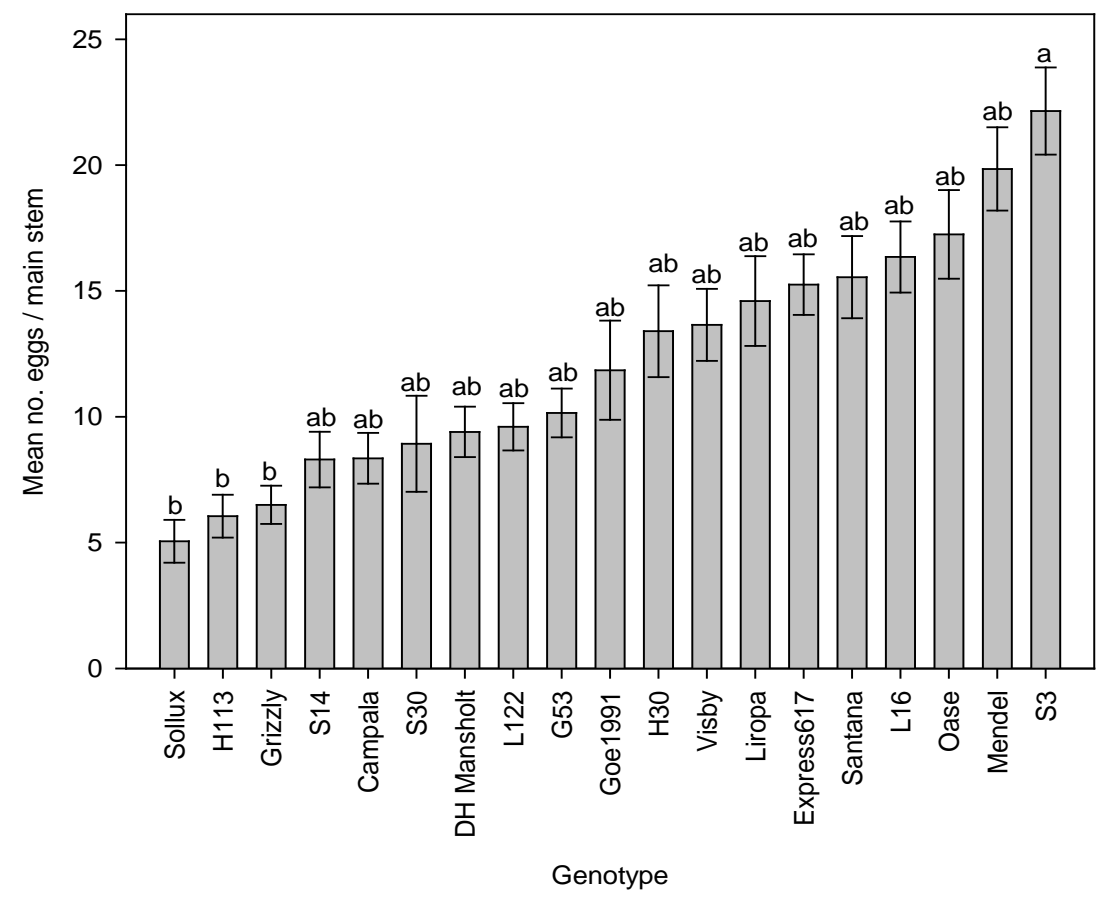

Fig. 1 Number of eggs deposited by Ceutorhynchus napi into stems of 19 Brassica napus genotypes. Samples collected on March $26^{\text {th }}$ 2012. Field experiment 2011/2012. Mean values $( \pm$ SE) of four replicates. Different letters indicate significant differences between genotypes, Kruskal-Wallis Test, $P \leq 0.05$ 
On March $26^{\text {th }}$, the resynthesized line L16 and the cultivar Santana were at BBCH growth stage 52, while the other test genotypes were at $\mathrm{BBCH}$ growth stage 51 (Table 3). At the same sampling date, the length of the stems differed significantly between individual genotypes $(H(18, N=76)=56.835, P=0.000)$. The stem length of the cultivar Sollux was significantly shorter compared to the stem length of the cultivar Visby (Table 3).

Table 3 BBCH growth stage and length of stem of 19 Brassica napus genotypes on March 26 $6^{\text {th }}$ 2012. Field experiment 2011/2012. Mean values $( \pm$ SE) of three to four replicates. Different letters indicate significant differences between genotypes, Kruskal-Wallis Test, $P \leq 0.05$

\begin{tabular}{llc}
\hline Genotype & BBCH growth stage & Length of stem $(\mathrm{cm}) \pm$ SE \\
\hline S3 & 51 & $14.73 \pm 0.84 \mathrm{ab}$ \\
L16 & 52 & $19.35 \pm 2.87 \mathrm{ab}$ \\
L122 & 51 & $10.20 \pm 0.39 \mathrm{ab}$ \\
G53 & 51 & $11.28 \pm 0.95 \mathrm{ab}$ \\
S30 & 51 & $11.28 \pm 0.84 \mathrm{ab}$ \\
H113 & 51 & $9.40 \pm 0.85 \mathrm{ab}$ \\
H30 & 51 & $9.45 \pm 0.53 \mathrm{ab}$ \\
S14 & 51 & $17.45 \pm 0.69 \mathrm{ab}$ \\
Sollux & 51 & $8.38 \pm 0.53 \mathrm{~b}$ \\
Campala & 51 & $10.25 \pm 0.72 \mathrm{ab}$ \\
Express617 & 51 & $12.53 \pm 0.64 \mathrm{ab}$ \\
Oase & 51 & $18.00 \pm 1.53 \mathrm{ab}$ \\
Mendel & 51 & $12.50 \pm 1.38 \mathrm{ab}$ \\
Visby & 51 & $19.70 \pm 1.30 \mathrm{a}$ \\
Santana & 52 & $16.95 \pm 1.48 \mathrm{ab}$ \\
Grizzly & 51 & $9.13 \pm 1.28 \mathrm{ab}$ \\
DH Mansholt & 51 & $10.83 \pm 0.99 \mathrm{ab}$ \\
Goe1991 & 51 & $15.33 \pm 1.43 \mathrm{ab}$ \\
Liropa & 51 & $12.83 \pm 0.99 \mathrm{ab}$ \\
\hline
\end{tabular}

The mean number of eggs deposited by $C$. napi into main stems was positively dependent upon stem length on March $26^{\text {th }}$ (Fig. 2), but not significantly dependent upon length of full-grown stems on May $8^{\text {th }}(R=0.384, F=2.944, P=0.104)$ (Table 7).

The multivariate PLS-DA analysis and the associated MANOVA revealed that the glucosinolate profiles of stems of the $B$. napus genotypes significantly differed between genotypes (61.44 \% explained by intergenotypic variance; pseudo- $F{ }_{11,198}=4.820, P<$ 0.001). However, multivariate PLSR analysis identified that there was no relationship between the number of eggs deposited by $C$. napi into main stems and the glucosinolate profile of stems (40.36 \% variance of number of eggs). Consequently, the glucosinolate profile of stems did not explain the number of eggs in the main stems.

When single contents of stem glucosinolates were related with the number of eggs deposited by $C$. napi, the mean number of eggs at the beginning of the oviposition period was negatively dependent upon stem contents of the aliphatic glucosinolate glucoalyssin (ALY) (y 


\section{Chapter IV}

$=16.623-1.124 x)$ and the indolyl glucosinolate neoglucobrassicin (NEO) $(y=17.343-$ 1.242x) and positively dependent upon stem contents of the aliphatic glucosinolate napoleiferin $(\mathrm{GNL})(\mathrm{y}=1.553+30.257 \mathrm{x})$ (Table 4).

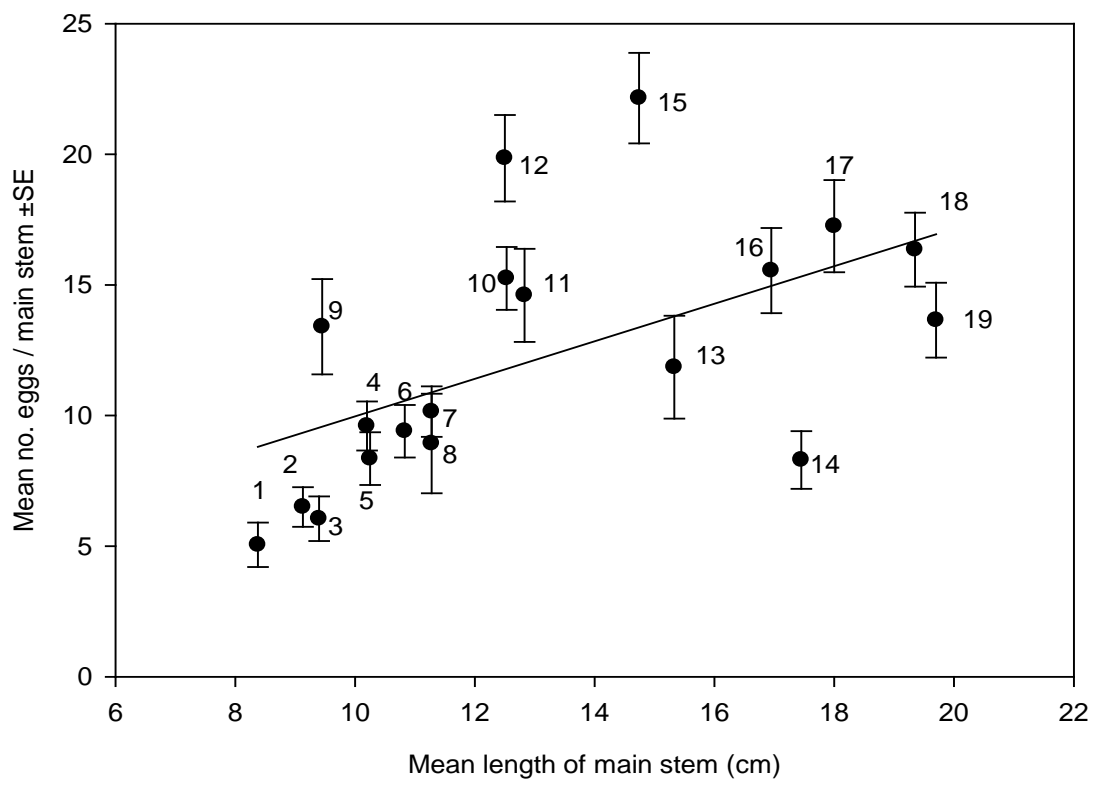

Fig. 2 Relationship between the number of eggs deposited by Ceutorhynchus napi into stems and the length of stems of 19 Brassica napus genotypes. Plant samples of March 26 ${ }^{\text {th }}$. Field experiment 2011/2012. Regression model: $\mathrm{y}=2.178+0.719 x ; R=0.552, F=7.433, P=0.014 ; 1=$ Sollux, $2=$ Grizzly, $3=$ H113, $4=$ L122, $5=$ Campala, 6 = DH Mansholt, 7 = G53, 8 = S30, 9 = H30, $10=$ Express617, $11=$ Liropa, $12=$ Mendel, $13=$ Goe1991, 14 = S14, 15 = S3, 16 = Santana, 17 = Oase, $18=$ L16, $19=$ Visby

Table 4 Relationships between the number of eggs deposited by Ceutorhynchus napi into main stems in samples of March $26^{\text {th }}$ and the contents of glucosinolates in the main stems of 19 Brassica napus genotypes on March $27^{\text {th }}$. Field experiment in 2011/2012. Linear Regression, $P \leq 0.05$. See Table 2 for denominations of glucosinolates

\begin{tabular}{llrl}
\hline Glucosinolates & \multicolumn{1}{l}{$R$} & \multicolumn{1}{l}{$P$} \\
\hline Total & 0.346 & 2.313 & 0.147 \\
Aliphatic & 0.271 & 1.348 & 0.262 \\
Indolyl & 0.440 & 4.090 & 0.059 \\
Aliphatic/Indolyl & 0.225 & 0.904 & 0.355 \\
PRO & 0.099 & 0.167 & 0.684 \\
RAA & 0.345 & 2.300 & 0.148 \\
GNL & $\mathbf{0 . 5 2 5}$ & $\mathbf{6 . 4 8 1}$ & $\mathbf{0 . 0 2 1}$ \\
ALY & $\mathbf{0 . 6 4 0}$ & $\mathbf{1 1 . 7 8 1}$ & $\mathbf{0 . 0 0 3}$ \\
GNA & 0.261 & 1.246 & 0.280 \\
GBN & 0.359 & 2.521 & 0.131 \\
4OH & 0.026 & 0.011 & 0.917 \\
GBC & 0.126 & 0.274 & 0.608 \\
4ME & 0.195 & 0.671 & 0.424 \\
NEO & $\mathbf{0 . 5 2 8}$ & $\mathbf{6 . 5 7 2}$ & $\mathbf{0 . 0 2 0}$ \\
NAS & 0.361 & 2.547 & 0.129 \\
\hline
\end{tabular}


The number of eggs in the main stems was not significantly dependent upon carbon content $(R=0.045, F=0.035, P=0.855)$, nitrogen content $(R=0.342, F=2.253, P=0.152)$ and C:N ratio ( $R=0.356, F=2.461, P=0.135)$ of main stems of genotypes. Results on carbon contents, nitrogen contents and C:N ratios of main stems are shown in Table 8.

Larval infestation by C. napi in 2011/2012 and 2012/2013: In 2012, the number of $C$. napi larvae in the main stem differed significantly between genotypes $\left(F_{22}, 67=2.518, P=\right.$ 0.002) (Table 5 and Fig. 3, top). The length of the full-grown stem used as a covariate significantly affected the number of larvae in the main stems (Table 5). The resynthesized line S30 contained significantly less larvae compared to the cultivar Mendel (Fig. 3, top). Over all tested genotypes, 10.02 larvae per main stem were found on average in stems of genotypes in 2012.

In 2013, the number of $C$. napi larvae in the main stem differed significantly between genotypes $(H(25, N=102)=64.284, P=0.000)($ Fig. 3 , bottom $)$. S30 contained significantly less larvae compared to the resynthesized line H10 and the cultivars Sollux and Grizzly (Fig. 3, bottom).

Table 5 Effect of the genotype and the covariate on the number of Ceutorhynchus napi larvae in the main stem in samples of May $8^{\text {th }}$ 2012. 23 Brassica napus genotypes in the field experiment in 2011/2012. Mean values of four replicates; Sample size $(N)$, degree of freedom $(D F), F$-value and $P$-value

\begin{tabular}{lllll}
\hline $2011 / 2012$ & $N$ & $D F$ & $F$ & $P$ \\
\hline $\begin{array}{l}\text { Factor: Genotype } \\
\begin{array}{l}\text { Covariate: } \\
\quad \text { Length of full-grown stem }\end{array}\end{array}$ & 92 & 22 & 2.518 & 0.002 \\
\hline
\end{tabular}

Larval infestation by C. pallidactylus in 2011/2012 and 2012/2013: In 2012, the number of $C$. pallidactylus larvae in the main stem differed significantly between genotypes $(H(22, N=92)=32.260, P=0.073)$ (Fig. 4 , top). In 2013, the mean number of larvae ranged from 0.63 larvae (S3) to 4.4 larvae per main stem (Liropa). The genotype did not significantly affected the number of larvae $(H(25, N=102)=42.847, P=0.055)$ (Fig. 4, bottom). 

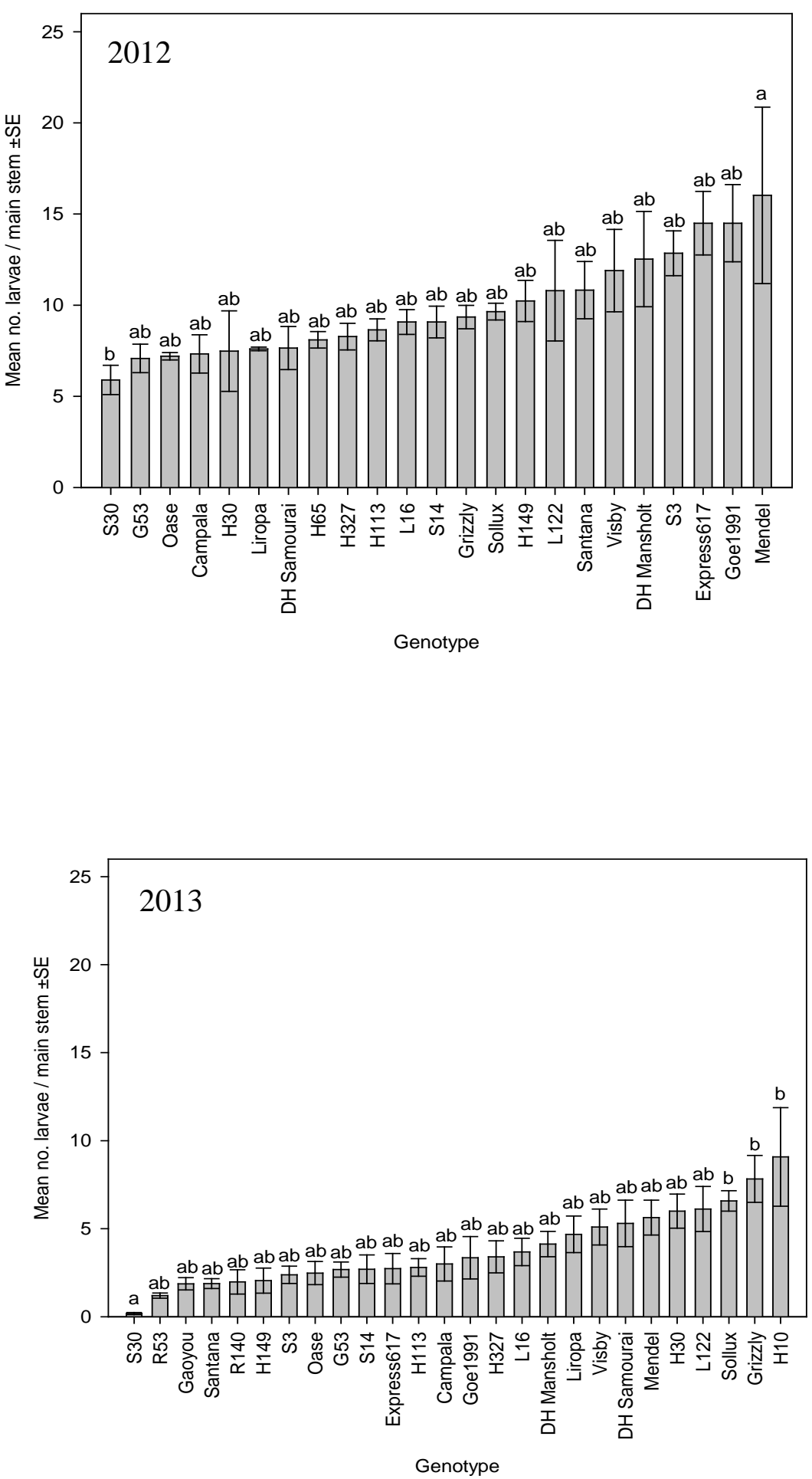

Fig. 3 Stem infestation of 23 and 26 Brassica napus genotypes by Ceutorhynchus napi larvae. Plant samples of May $8^{\text {th }} 2012$ (top) and May 22 2013 (bottom). Mean values ( \pm SE) of four replicates in 2012 and three to four replicates in 2013. Different letters indicate significant differences between genotypes, Bonferroni Test, $P \leq 0.05$ (top) and Kruskal-Wallis Test, $P \leq 0.05$ (bottom) 

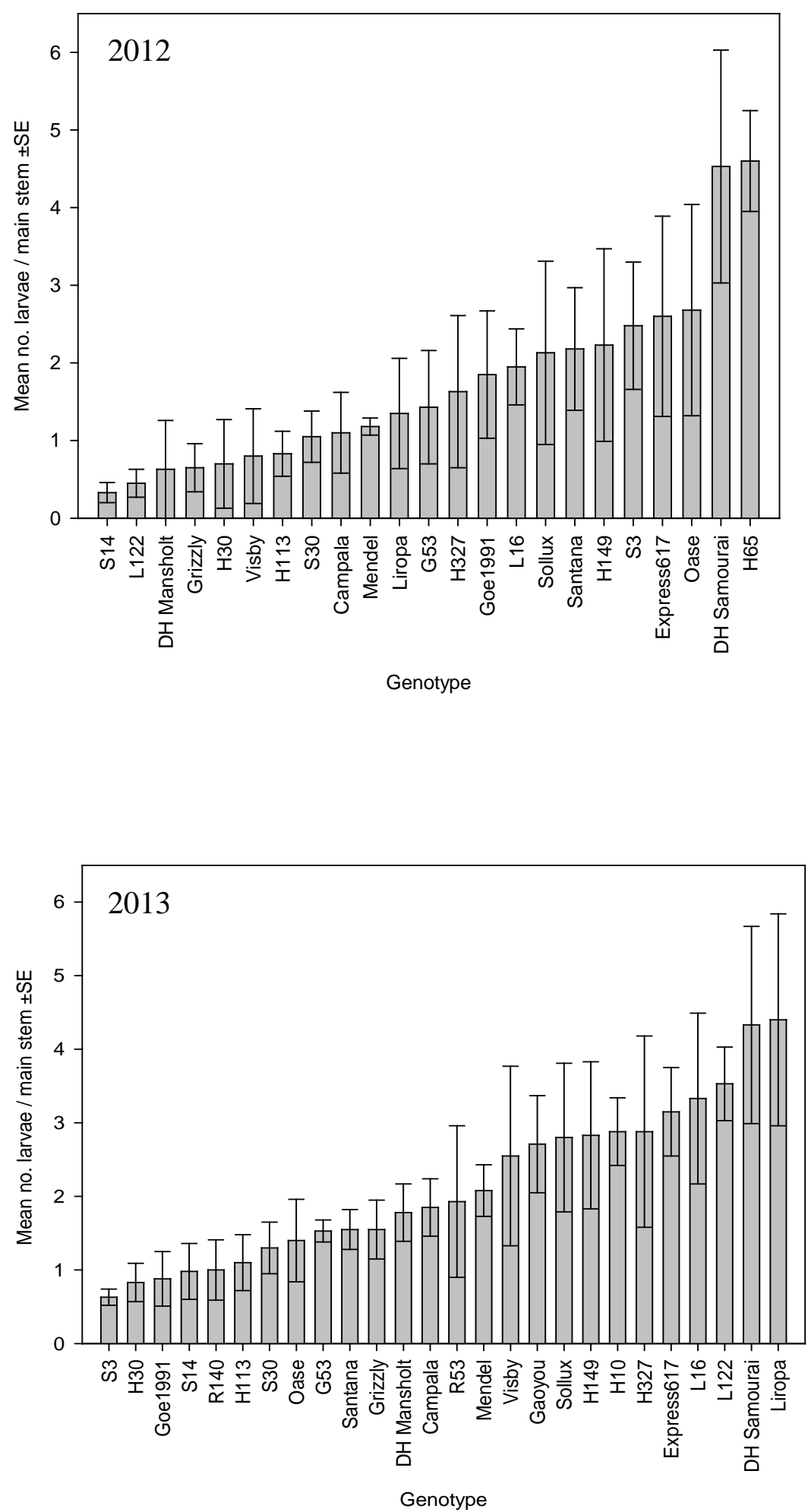

Fig. 4 Stem infestation of 23 and 26 Brassica napus genotypes by Ceutorhynchus pallidactylus larvae. Plant samples of May $8^{\text {th }} 2012$ (top) and May $22^{\text {nd }} 2013$ (bottom). Mean values ( \pm SE) of four replicates in 2012 and three to four replicates in 2013. KW-ANOVA, $P>0.05$ 
Susceptibility to larval infestation by C. napi and glucosinolates: In 2012 and 2013, there was a broad variability of the glucosinolate contents of stems between the tested genotypes (Table 9 and Table 10). In both years, the resynthesized line L16 and the cultivar Liropa showed the lowest total glucosinolate content and the lowest aliphatic/indolyl ratio in stems. In all tested genotypes, the aliphatic glucosinolate contents in stems were higher compared to the indolyl contents, except for the resynthesized line L16 and the cultivars Liropa and Santana. In those three genotypes the indolyl contents in stems were higher than the aliphatic contents.

In 2012, the multivariate PLS-DA analysis and the associated MANOVA revealed that the glucosinolate profiles of stems of the $B$. napus genotypes significantly differed between genotypes (57.56 \% explained by intergenotypic variance; pseudo- $F_{11,242}=5.270, P<$ 0.001). However, the multivariate PLSR analysis identified that there was no relationship between the number of $C$. napi larvae in main stems and the glucosinolate profile of stems (11.01\% variance of the number of larvae). Consequently, the glucosinolate profile of stems did not explain the number of $C$. napi larvae in main stems. When single contents of stem glucosinolates were related with the number of $C$. napi larvae in main stems also no relationships between the number of larvae and the stem contents of glucosinolates were found (Table 6).

In 2013, the multivariate PLS-DA and the associated MANOVA revealed that the glucosinolate profiles of stems of the $B$. napus genotypes significantly differed between genotypes (58.62 \% explained by intergenotypic variance; pseudo- $F$ 11, $275=5.140, P<$ 0.001). However, the multivariate PLSR analysis identified that there was no relationship between the number of $C$. napi larvae in main stems and the glucosinolate profile of stems (10.83 \% variance of the number of larvae). Consequently, the glucosinolate profile of stems did not explain the number of $C$. napi larvae in main stems.

Additionally, when single contents of stem glucosinolates were related with the number of $C$. napi larvae in main stems also no relationships between the number of larvae and the stem contents of glucosinolates were found (Table 6). 
Table 6 Relationships between the number of Ceutorhynchus napi larvae in main stems in samples of May $8^{\text {th }}$ 2012 and May $22^{\text {nd }} 2013$ and the content of glucosinolates in main stems on March $27^{\text {th }} 2012$ and April $17^{\text {th }}$ 2013, respectively. 23 Brassica napus and 26 B. napus genotypes grown in field experiments in 2011/2012 and 2012/2013, respectively. Linear Regression, $P \leq 0.05$. See Table 2 for denominations of glucosinolates

\begin{tabular}{lllllll}
\hline Glucosinolates & $\mathbf{2 0 1 2}$ & & & $\mathbf{2 0 1 3}$ & \\
& $R$ & $F$ & $P$ & $R$ & $F$ & $P$ \\
\hline Total & 0.189 & 0.774 & 0.389 & 0.045 & 0.050 & 0.826 \\
Aliphatic & 0.161 & 0.559 & 0.463 & 0.034 & 0.027 & 0.871 \\
Indolyl & 0.174 & 0.658 & 0.426 & 0.041 & 0.040 & 0.843 \\
Aliphatic/Indolyl & 0.129 & 0.356 & 0.557 & 0.148 & 0.541 & 0.469 \\
PRO & 0.207 & 0.944 & 0.342 & 0.100 & 0.243 & 0.627 \\
RAA & 0.295 & 2.001 & 0.172 & 0.049 & 0.058 & 0.812 \\
GNL & 0.057 & 0.068 & 0.797 & 0.004 & 0.000 & 0.984 \\
ALY & 0.067 & 0.095 & 0.761 & 0.180 & 0.802 & 0.379 \\
GNA & 0.208 & 0.950 & 0.341 & 0.058 & 0.080 & 0.780 \\
GBN & 0.033 & 0.023 & 0.880 & 0.131 & 0.422 & 0.522 \\
4OH & 0.341 & 2.755 & 0.112 & 0.172 & 0.729 & 0.402 \\
GBC & 0.341 & 2.755 & 0.112 & 0.107 & 0.278 & 0.603 \\
4ME & 0.088 & 0.162 & 0.691 & 0.174 & 0.748 & 0.396 \\
NEO & 0.016 & 0.006 & 0.941 & 0.277 & 1.989 & 0.171 \\
NAS & 0.227 & 1.137 & 0.298 & 0.167 & 0.688 & 0.415 \\
\hline
\end{tabular}

Susceptibility to larval infestation by C. pallidactylus and glucosinolates: In 2012 and 2013, there was a broad variability of the glucosinolate contents of leaves between the tested genotypes (Table 11 and Table 12). In both years, the resynthesized line L16 and the cultivars Liropa and Santana showed the lowest total glucosinolate content and the lowest aliphatic/indolyl ratio in leaves. In all tested genotypes, the aliphatic glucosinolate contents in leaves were higher compared to the indolyl contents, except for the resynthesized line L16 and the cultivars Liropa and Santana.

In 2012, the multivariate PLS-DA analysis and the associated MANOVA revealed that the glucosinolate profiles of leaves of the $B$. napus genotypes significantly differed between genotypes (64.90\% explained by intergenotypic variance; pseudo- $F_{11,242}=4.040, P<$ 0.001).

In 2013, the multivariate PLS-DA and the associated MANOVA revealed that the glucosinolate profiles of stems of the $B$. napus genotypes significantly differed between genotypes (61.15 \% explained by intergenotypic variance; pseudo- $\left.F_{11,275}=4.650, P<0.001\right)$.

Performance of C. napi and C. pallidactylus larvae, morphological plant traits and plant nutrients: In 2012, the genotype did not significantly affect the length of full-grown stems $(H(22, N=91)=48.630, P=0.051)$, ranging from $36.31 \mathrm{~cm}$ (Grizzly) to $59.81 \mathrm{~cm}$ (S14) (Table 7). In 2013, the length of the full grown-stem significantly differed between 
Chapter IV

genotypes $(H(25, N=102)=79.422, P=0.000)$. The resynthesized line S14 showed a significantly longer full-grown stem compared to the resynthesized lines H30, H149, R140 and R53 (Table 7). In 2013, the number of C. napi larvae in main stems was not significantly dependent upon length of full-grown stems $(R=0.133, F=0.435, P=0.516)$.

In 2012, the genotype did not significantly affect the length of the larval feeding tunnels $(H(22, N=91)=46.004, P=0.062)$, ranging from $17.59 \mathrm{~cm}(\mathrm{~S} 30)$ to $33.54 \mathrm{~cm}(\mathrm{H} 65)$ (Table 7). In 2013, the length of the larval feeding tunnels significantly differed between individual genotypes $(\mathrm{H}(25, N=102)=65.953, P=0.000)$. The resynthesized line S30 showed significantly shorter larval feeding tunnels compared to the resynthesized line H10 and the cultivars Visby and Liropa (Table 7). In 2013, the number of C. napi larvae in main stems was significantly positive dependent upon length of larval feeding tunnels $(y=0.591+$ $0.175 x ; R=0.772, F=35.315, P<0.001)$.

In 2012, the amount of larval feeding as reflected by the stem injury coefficient did not significantly differ between genotypes $(H(22, N=91)=40.857, P=0.009)$, ranging from 0.40 (S30) to 0.65 (Mendel) (Table 7). In 2013, the stem injury coefficient significantly differed between genotypes $(H(25, N=102)=65.969, P=0.000)$. The resynthesized line S30 showed a significantly lower stem injury coefficient compared to the resynthesized lines L122, H30 and H10 (Table 7). In 2013, the number of C. napi larvae was significantly positive dependent upon stem injury coefficients $(\mathrm{y}=-0.568+17.039 \mathrm{x} ; R=0.758, F=$ 32.354, $P<0.001)$.

In 2013, the biomass and the dry biomass of stems did not significantly differ between genotypes $(H(25, N=103)=3.384, P=0.100)$ and $(H(25, N=104)=32.147, P=0.154)$, respectively (Table 8). The carbon content of the stem differed significantly among genotypes $(H(25, N=104)=48.417, P=0.003)$. The resynthesized line S3 showed a significantly higher carbon content in main stems compared to the resynthesized line H149 (Table 8). The nitrogen content of the stems differed significantly between genotypes $(H(25, N=104)=$ 63.148, $P=0.000)$. The resynthesized line S14 showed a significantly higher nitrogen content compared to resynthesized lines R140 and H10 (Table 8). Similarly, the C:N ratio of stems differed significantly between individual genotypes $(H(25, N=104)=63.678, P=0.000)$. The resynthesized lines R140 and H10 showed a significantly higher ratio compared to the resynthesized line S14 (Table 8). 
Table 7 Length of full-grown stem, length of feeding tunnels of Ceutorhynchus napi and Ceutorhynchus pallidactylus larvae and stem injury coefficient in samples of May $8^{\text {th }}, 2012$ and May $22^{\text {nd }}, 2013$. Mean values $( \pm$ SE) of three to four replicates; Different letters within each column indicate significant differences, Kruskal-Wallis Test, $P \leq$ 0.05

\begin{tabular}{|c|c|c|c|c|c|c|}
\hline \multirow[t]{2}{*}{ Genotype } & \multicolumn{2}{|c|}{ Length of full-grown stem (cm) } & \multicolumn{2}{|c|}{ Length of feeding tunnels (cm) } & \multicolumn{2}{|c|}{ Stem injury coefficient } \\
\hline & 2012 & 2013 & 2012 & 2013 & 2012 & 2013 \\
\hline S30 & $43.21 \pm 5.27$ & $92.36 \pm 8.18$ abc & $17.59 \pm 2.90$ & $4.20 \pm 0.45 \mathrm{a}$ & $0.40 \pm 0.03$ & $0.05 \pm 0.00 \mathrm{c}$ \\
\hline S14 & $59.81 \pm 3.21$ & $130.54 \pm 5.19 \mathrm{a}$ & $26.26 \pm 1.90$ & $23.83 \pm 3.32 \mathrm{abc}$ & $0.44 \pm 0.02$ & $0.18 \pm 0.02 \mathrm{abc}$ \\
\hline H113 & $36.35 \pm 2.05$ & $92.48 \pm 3.75$ abc & $23.19 \pm 5.54$ & $21.68 \pm 2.96$ abc & $0.63 \pm 0.13$ & $0.23 \pm 0.02 \mathrm{abc}$ \\
\hline G53 & $40.46 \pm 5.60$ & $105.94 \pm 3.94 \mathrm{abc}$ & $23.16 \pm 2.79$ & $22.75 \pm 3.17 \mathrm{abc}$ & $0.58 \pm 0.01$ & $0.22 \pm 0.03 \mathrm{abc}$ \\
\hline H327 & $44.83 \pm 3.54$ & $93.95 \pm 5.66$ abc & $22.88 \pm 2.03$ & $26.95 \pm 3.56 \mathrm{abc}$ & $0.51 \pm 0.01$ & $0.29 \pm 0.03 a b c$ \\
\hline L122 & $46.24 \pm 3.50$ & $105.95 \pm 2.07 \mathrm{abc}$ & $22.09 \pm 1.86$ & $41.48 \pm 3.16$ abc & $0.48 \pm 0.02$ & $0.39 \pm 0.03 \mathrm{ab}$ \\
\hline L16 & $54.34 \pm 1.68$ & $113.69 \pm 1.71 \mathrm{abc}$ & $28.16 \pm 3.21$ & $27.21 \pm 4.89 \mathrm{abc}$ & $0.51 \pm 0.04$ & $0.24 \pm 0.04 \mathrm{abc}$ \\
\hline H65 & $56.31 \pm 1.95$ & - & $33.54 \pm 1.47$ & - & $0.59 \pm 0.01$ & - \\
\hline S3 & $55.28 \pm 2.46$ & $102.60 \pm 1.54 \mathrm{abc}$ & $33.27 \pm 2.59$ & $14.23 \pm 2.29 \mathrm{abc}$ & $0.60 \pm 0.03$ & $0.14 \pm 0.02$ bc \\
\hline Н30 & $37.56 \pm 5.72$ & $68.74 \pm 1.89$ с & $19.20 \pm 3.15$ & $24.48 \pm 1.81$ abc & $0.53 \pm 0.08$ & $0.36 \pm 0.03 \mathrm{ab}$ \\
\hline H149 & $52.23 \pm 5.11$ & $73.03 \pm 7.11 \mathrm{c}$ & $31.38 \pm 3.67$ & $24.10 \pm 3.65 a b c$ & $0.60 \pm 0.03$ & $0.33 \pm 0.02 \mathrm{abc}$ \\
\hline R140 & - & $69.69 \pm 3.71 \mathrm{c}$ & - & $16.23 \pm 1.74$ abc & - & $0.23 \pm 0.02 \mathrm{abc}$ \\
\hline R53 & - & $71.34 \pm 8.42$ c & - & $12.75 \pm 2.22 \mathrm{ab}$ & - & $0.18 \pm 0.02 a b c$ \\
\hline H10 & - & $86.79 \pm 9.45 a b c$ & - & $46.83 \pm 5.11 \mathrm{c}$ & - & $0.54 \pm 0.02 \mathrm{a}$ \\
\hline DH Samourai & $42.90 \pm 2.61$ & $110.01 \pm 3.43$ abc & $25.30 \pm 3.06$ & $26.28 \pm 1.66$ abc & $0.59 \pm 0.06$ & $0.24 \pm 0.01 \mathrm{abc}$ \\
\hline DH Mansholt & $38.49 \pm 2.86$ & $95.34 \pm 3.55 \mathrm{abc}$ & $21.14 \pm 1.80$ & $26.20 \pm 2.82 \mathrm{abc}$ & $0.55 \pm 0.02$ & $0.28 \pm 0.04 \mathrm{abc}$ \\
\hline Mendel & $46.30 \pm 3.11$ & $116.15 \pm 5.39 \mathrm{abc}$ & $29.54 \pm 0.98$ & $36.50 \pm 5.63 a b c$ & $0.65 \pm 0.05$ & $0.32 \pm 0.05 a b c$ \\
\hline Campala & $45.59 \pm 0.96$ & $97.90 \pm 8.11$ abc & $19.21 \pm 1.27$ & $23.33 \pm 4.70 \mathrm{abc}$ & $0.42 \pm 0.03$ & $0.24 \pm 0.03 a b c$ \\
\hline Grizzly & $36.31 \pm 3.95$ & $97.48 \pm 2.48$ abc & $19.99 \pm 1.15$ & $25.18 \pm 2.23$ abc & $0.56 \pm 0.04$ & $0.26 \pm 0.03 a b c$ \\
\hline Visby & $61.85 \pm 6.96$ & $123.16 \pm 4.50 \mathrm{a}$ & $30.93 \pm 3.10$ & $37.35 \pm 4.05$ bc & $0.50 \pm 0.01$ & $0.31 \pm 0.04 a b c$ \\
\hline Express617 & $55.15 \pm 6.18$ & $120.63 \pm 3.09 \mathrm{ab}$ & $25.88 \pm 2.99$ & $19.11 \pm 2.49$ abc & $0.47 \pm 0.03$ & $0.16 \pm 0.02 \mathrm{bc}$ \\
\hline Goe1991 & $44.79 \pm 2.92$ & $94.13 \pm 6.58$ abc & $23.18 \pm 1.88$ & $17.85 \pm 4.53 \mathrm{abc}$ & $0.53 \pm 0.07$ & $0.18 \pm 0.04 a b c$ \\
\hline Liropa & $49.00 \pm 1.56$ & $108.90 \pm 3.57 \mathrm{abc}$ & $28.20 \pm 4.42$ & $37.23 \pm 5.32$ bc & $0.58 \pm 0.10$ & $0.34 \pm 0.04 a b c$ \\
\hline Santana & $48.44 \pm 3.15$ & $90.40 \pm 3.64$ abc & $28.25 \pm 2.68$ & $21.93 \pm 7.57 \mathrm{abc}$ & $0.58 \pm 0.02$ & $0.25 \pm 0.09$ abc \\
\hline Oase & $45.44 \pm 3.15$ & $95.63 \pm 4.24 \mathrm{abc}$ & $22.11 \pm 2.26$ & $15.73 \pm 2.41 \mathrm{abc}$ & $0.48 \pm 0.02$ & $0.17 \pm 0.03 a b c$ \\
\hline Gaoyou & - & $111.86 \pm 2.50 \mathrm{abc}$ & - & $28.35 \pm 5.98 a b c$ & - & $0.25 \pm 0.05 a b c$ \\
\hline Sollux & $50.66 \pm 2.80$ & $106.30 \pm 0.55 \mathrm{abc}$ & $28.43 \pm 4.43$ & $29.84 \pm 2.98$ abc & $0.55 \pm 0.06$ & $0.28 \pm 0.03 a b c$ \\
\hline
\end{tabular}




\section{Chapter IV}

Table 8 Biomass and carbon and nitrogen content of 26 Brassica napus genotypes. Plant samples of April $15^{\text {th }}$ 2013. Mean values $( \pm$ SE) of four replicates. Different letters within each column indicate significant differences between genotypes, Kruskal-Wallis Test, $P \leq 0.05$

\begin{tabular}{|c|c|c|c|c|c|}
\hline Genotype & Biomass (g) & Dry biomass (g) & C-content (\%) & N-content (\%) & Stem C:N ratio \\
\hline S30 & $9.93 \pm 2.46$ & $3.83 \pm 1.01$ & $40.99 \pm 0.32 \mathrm{ab}$ & $5.29 \pm 0.09 a b$ & $7.75 \pm 0.12 \mathrm{ab}$ \\
\hline S14 & $8.05 \pm 2.01$ & $3.15 \pm 0.68$ & $41.68 \pm 0.26 \mathrm{ab}$ & $6.25 \pm 0.14 \mathrm{a}$ & $6.68 \pm 0.13 b$ \\
\hline H113 & $5.21 \pm 0.75$ & $2.34 \pm 0.37$ & $41.39 \pm 0.18 a b$ & $5.69 \pm 0.25 \mathrm{ab}$ & $7.27 \pm 0.32 \mathrm{ab}$ \\
\hline G53 & $8.25 \pm 0.63$ & $2.30 \pm 0.22$ & $41.47 \pm 0.45 \mathrm{ab}$ & $6.02 \pm 0.23 \mathrm{ab}$ & $6.89 \pm 0.21 \mathrm{ab}$ \\
\hline H327 & $8.71 \pm 1.01$ & $2.75 \pm 0.17$ & $41.18 \pm 0.14 \mathrm{ab}$ & $6.11 \pm 0.08 \mathrm{ab}$ & $6.74 \pm 0.10 \mathrm{ab}$ \\
\hline L122 & $7.08 \pm 1.51$ & $3.08 \pm 0.50$ & $40.96 \pm 0.66 \mathrm{ab}$ & $5.38 \pm 0.23 \mathrm{ab}$ & $7.65 \pm 0.26 \mathrm{ab}$ \\
\hline L16 & $7.46 \pm 1.98$ & $2.26 \pm 0.39$ & $40.28 \pm 0.28 \mathrm{ab}$ & $5.80 \pm 0.21 \mathrm{ab}$ & $6.98 \pm 0.29 \mathrm{ab}$ \\
\hline S3 & $7.13 \pm 1.86$ & $2.82 \pm 0.66$ & $42.13 \pm 0.16 \mathrm{a}$ & $5.77 \pm 0.08 \mathrm{ab}$ & $7.30 \pm 0.07 a b$ \\
\hline Н30 & $7.45 \pm 2.25$ & $2.27 \pm 0.62$ & $40.87 \pm 0.13 a b$ & $5.96 \pm 0.32 \mathrm{ab}$ & $6.86 \pm 0.40 \mathrm{ab}$ \\
\hline H149 & $9.20 \pm 0.79$ & $3.69 \pm 0.61$ & $40.01 \pm 0.26 \mathrm{~b}$ & $5.88 \pm 0.11 \mathrm{ab}$ & $6.81 \pm 0.09 \mathrm{ab}$ \\
\hline R140 & $10.62 \pm 1.86$ & $3.33 \pm 0.63$ & $40.55 \pm 0.30 \mathrm{ab}$ & $4.79 \pm 0.13 \mathrm{~b}$ & $8.50 \pm 0.23 \mathrm{a}$ \\
\hline R53 & $6.85 \pm 0.97$ & $2.99 \pm 0.48$ & $40.74 \pm 0.30 \mathrm{ab}$ & $5.52 \pm 0.25 a b$ & $7.42 \pm 0.28 \mathrm{ab}$ \\
\hline H10 & $6.39 \pm 1.01$ & $3.11 \pm 0.48$ & $40.51 \pm 0.06 \mathrm{ab}$ & $4.49 \pm 0.27 b$ & $8.92 \pm 0.52$ a \\
\hline DH Samourai & $8.75 \pm 1.20$ & $2.18 \pm 0.42$ & $40.95 \pm 0.34 \mathrm{ab}$ & $5.64 \pm 0.12 \mathrm{ab}$ & $7.27 \pm 0.10 \mathrm{ab}$ \\
\hline DH Mansholt & $7.56 \pm 1.52$ & $2.70 \pm 0.40$ & $40.69 \pm 0.29 \mathrm{ab}$ & $5.37 \pm 0.15 a b$ & $7.60 \pm 0.21 \mathrm{ab}$ \\
\hline Mendel & $10.95 \pm 1.19$ & $2.92 \pm 0.24$ & $40.91 \pm 0.25 a b$ & $5.26 \pm 0.19 a b$ & $7.78 \pm 0.27 \mathrm{ab}$ \\
\hline Campala & $8.41 \pm 1.04$ & $3.14 \pm 0.67$ & $40.63 \pm 0.23 \mathrm{ab}$ & $5.74 \pm 0.12 \mathrm{ab}$ & $7.09 \pm 0.14 \mathrm{ab}$ \\
\hline Grizzly & $8.12 \pm 1.83$ & $2.25 \pm 0.29$ & $41.17 \pm 0.15 a b$ & $5.76 \pm 0.16 \mathrm{ab}$ & $7.17 \pm 0.18 \mathrm{ab}$ \\
\hline Visby & $12.05 \pm 0.47$ & $3.62 \pm 0.33$ & $40.74 \pm 0.22 \mathrm{ab}$ & $5.15 \pm 0.05 \mathrm{ab}$ & $7.91 \pm 0.09 \mathrm{ab}$ \\
\hline Express617 & $10.70 \pm 0.31$ & $3.30 \pm 0.33$ & $40.80 \pm 0.18 a b$ & $5.44 \pm 0.21 \mathrm{ab}$ & $7.28 \pm 0.22 \mathrm{ab}$ \\
\hline Goe1991 & $8.01 \pm 2.19$ & $3.29 \pm 0.86$ & $41.91 \pm 0.29 \mathrm{ab}$ & $5.89 \pm 0.16 \mathrm{ab}$ & $7.13 \pm 0.15 a b$ \\
\hline Liropa & $9.52 \pm 1.41$ & $3.05 \pm 0.20$ & $41.10 \pm 0.11 \mathrm{ab}$ & $5.49 \pm 0.18 \mathrm{ab}$ & $7.51 \pm 0.23 \mathrm{ab}$ \\
\hline Santana & $9.16 \pm 1.79$ & $2.82 \pm 0.26$ & $41.51 \pm 0.16 \mathrm{ab}$ & $5.43 \pm 0.23 \mathrm{ab}$ & $7.68 \pm 0.30 \mathrm{ab}$ \\
\hline Oase & $13.12 \pm 1.38$ & $3.72 \pm 0.26$ & $40.76 \pm 0.43 \mathrm{ab}$ & $5.04 \pm 0.14 \mathrm{ab}$ & $8.09 \pm 0.29 \mathrm{ab}$ \\
\hline Gaoyou & $15.18 \pm 1.25$ & $4.18 \pm 0.22$ & $40.56 \pm 0.53 \mathrm{ab}$ & $4.98 \pm 0.12 \mathrm{ab}$ & $8.16 \pm 0.14 \mathrm{ab}$ \\
\hline Sollux & $7.06 \pm 0.92$ & $2.27 \pm 0.30$ & $41.02 \pm 0.42 \mathrm{ab}$ & $5.94 \pm 0.23 \mathrm{ab}$ & $6.91 \pm 0.27 \mathrm{ab}$ \\
\hline
\end{tabular}

The number of $C$. napi larvae in the sample of 2013 was not significantly dependent upon carbon and nitrogen content in stems and C:N ratio of stems in samples of $2013(R=$ 0.093, $F=0.210, P=0.651 ; R=0.081, F=0.160, P=0.693 ; R=0.116, F=0.325, P=$ $0.574)$, respectively. 
Table 9 Glucosinolate contents ( $\mu$ mol / g D.W.) of stems of 23 Brassica napus genotypes on March $27^{\text {th }}$ 2012. Mean values of three to four replicates. See Table 2 for denominations of glucosinolates

\begin{tabular}{|c|c|c|c|c|c|c|c|c|c|c|c|c|c|c|c|}
\hline Genotype & Total & Aliphatic & Indolyl & $\mathrm{A} / \mathrm{I}$ & PRO & RAA & GNL & ALY & GNA & GBN & GBC & $4 \mathrm{OH}$ & $4 \mathrm{ME}$ & NEO & NAS \\
\hline Goe1991 & 12.37 & 8.27 & 3.46 & 2.38 & 4.10 & 0.10 & 0.42 & 3.20 & 0.00 & 0.45 & 0.92 & 0.00 & 0.17 & 2.36 & 0.64 \\
\hline Santana & 12.31 & 4.94 & 7.25 & 0.68 & 2.81 & 0.00 & 0.39 & 1.16 & 0.00 & 0.57 & 3.20 & 0.03 & 0.33 & 3.7 & 0.12 \\
\hline H30 & 18.54 & 13.29 & 4.58 & 2.98 & 6.15 & 0.00 & 0.46 & 5.43 & 0.00 & 1.24 & 1.17 & 0.00 & 0.17 & 3.24 & 0.67 \\
\hline S3 & 48.64 & 43.49 & 3.71 & 11.84 & 29.8 & 0.00 & 0.45 & 2.23 & 5.70 & 5.32 & 2.41 & 0.00 & 0.15 & 1.14 & 1.44 \\
\hline DH Mansholt & 40.05 & 26.78 & 11.21 & 2.44 & 13.03 & 0.11 & 0.27 & 7.10 & 0.62 & 5.66 & 7.55 & 0.00 & 0.38 & 3.28 & 2.05 \\
\hline Н327 & 21.88 & 13.31 & 7.94 & 1.99 & 6.92 & 0.19 & 0.49 & 3.66 & 0.26 & 1.78 & 2.30 & 0.02 & 0.26 & 5.35 & 0.63 \\
\hline H149 & 22.19 & 17.97 & 3.94 & 4.96 & 11.76 & 0.00 & 0.3 & 2.55 & 0.41 & 2.95 & 2.39 & 0.00 & 0.12 & 1.43 & 0.27 \\
\hline Liropa & 10.52 & 2.90 & 7.28 & 0.53 & 1.49 & 0.00 & 0.36 & 0.46 & 0.05 & 0.53 & 2.44 & 0.04 & 0.35 & 4.45 & 0.34 \\
\hline S30 & 13.68 & 9.23 & 4.03 & 2.34 & 4.22 & 0.24 & 0.4 & 1.94 & 0.31 & 2.21 & 1.80 & 0.01 & 0.21 & 2.01 & 0.43 \\
\hline Campala & 26.35 & 14.35 & 11.63 & 1.24 & 6.53 & 0.00 & 0.44 & 2.41 & 0.37 & 4.60 & 3.71 & 0.00 & 0.23 & 7.69 & 0.37 \\
\hline Grizzly & 26.41 & 16.33 & 9.04 & 2.14 & 10.37 & 0.00 & 0.40 & 3.86 & 1.71 & 0.00 & 3.43 & 0.00 & 0.27 & 5.34 & 1.04 \\
\hline Mendel & 21.78 & 12.55 & 8.49 & 1.48 & 6.25 & 0.00 & 0.37 & 1.81 & 0.61 & 3.52 & 3.96 & 0.00 & 0.22 & 4.3 & 0.74 \\
\hline DH Samourai & 18.18 & 13.00 & 5.00 & 2.6 & 6.64 & 0.00 & 0.36 & 2.67 & 0.37 & 2.96 & 2.43 & 0.09 & 0.26 & 2.23 & 0.18 \\
\hline G53 & 26.86 & 21.09 & 5.30 & 4.63 & 11.21 & 0.42 & 0.25 & 2.06 & 1.23 & 5.92 & 2.53 & 0.01 & 0.11 & 2.65 & 0.47 \\
\hline H113 & 42.8 & 32.08 & 8.27 & 4.09 & 18.83 & 0.10 & 0.14 & 7.91 & 0.19 & 4.91 & 2.43 & 0.08 & 0.18 & 5.58 & 2.45 \\
\hline Visby & 19.38 & 15.21 & 3.86 & 4.08 & 7.27 & 0.00 & 0.36 & 4.06 & 0.31 & 3.21 & 2.36 & 0.04 & 0.10 & 1.35 & 0.31 \\
\hline Express617 & 29.81 & 17.72 & 11.09 & 1.65 & 8.57 & 0.00 & 0.4 & 3.55 & 0.53 & 4.67 & 3.95 & 0.00 & 0.29 & 6.86 & 0.99 \\
\hline Oase & 20.66 & 15.26 & 4.82 & 3.66 & 7.07 & 0.00 & 0.39 & 2.66 & 0.60 & 4.54 & 2.50 & 0.02 & 0.15 & 2.15 & 0.58 \\
\hline L16 & 9.57 & 3.33 & 6.1 & 0.54 & 1.71 & 0.00 & 0.34 & 0.69 & 0.00 & 0.60 & 2.84 & 0.06 & 0.12 & 3.08 & 0.14 \\
\hline S14 & 40.55 & 32.10 & 7.98 & 4.06 & 12.72 & 0.10 & 0.28 & 7.80 & 0.89 & 10.31 & 1.64 & 0.00 & 0.19 & 6.14 & 0.47 \\
\hline Sollux & 59.78 & 46.25 & 11.62 & 4.04 & 19.37 & 0.03 & 0.24 & 9.88 & 2.03 & 14.7 & 3.83 & 0.00 & 0.28 & 7.50 & 1.92 \\
\hline L122 & 37.29 & 25.86 & 10.21 & 2.55 & 14.50 & 0.00 & 0.34 & 6.18 & 0.44 & 4.39 & 4.50 & 0.00 & 0.22 & 5.49 & 1.22 \\
\hline H65 & 10.86 & 6.27 & 3.59 & 1.54 & 2.81 & 0.00 & 0.38 & 1.26 & 0.26 & 1.56 & 2.00 & 0.07 & 0.23 & 1.30 & 0.99 \\
\hline
\end{tabular}


Chapter IV

Table 10 Glucosinolate contents ( $\mu \mathrm{mol} / \mathrm{g}$ D.W.) of stems of 26 Brassica napus genotypes on April $17^{\text {th }}$ 2013. Mean values of three to four replicates. See Table 2 for denominations of glucosinolates

\begin{tabular}{|c|c|c|c|c|c|c|c|c|c|c|c|c|c|c|c|}
\hline Genotype & Total & Aliphatic & Indolyl & $\mathrm{A} / \mathrm{I}$ & PRO & RAA & GNL & ALY & GNA & GBN & GBC & $4 \mathrm{OH}$ & $4 \mathrm{ME}$ & NEO & NAS \\
\hline Goe1991 & 11.10 & 7.05 & 3.73 & 1.96 & 2.48 & 0.03 & 0.16 & 2.86 & 0.05 & 1.47 & 1.59 & 0.09 & 0.32 & 1.74 & 0.31 \\
\hline Gaoyou & 31.45 & 25.92 & 3.97 & 7.56 & 9.56 & 0.17 & 0.23 & 5.13 & 1.04 & 9.80 & 2.37 & 0.35 & 0.36 & 0.90 & 1.56 \\
\hline Santana & 12.00 & 4.86 & 6.96 & 0.73 & 1.71 & 0.00 & 0.13 & 1.41 & 0.11 & 1.50 & 3.77 & 0.26 & 0.54 & 2.41 & 0.17 \\
\hline Н30 & 25.46 & 18.53 & 6.34 & 3.34 & 6.51 & 0.04 & 0.26 & 6.70 & 0.35 & 4.67 & 3.43 & 0.13 & 0.50 & 2.28 & 0.59 \\
\hline S3 & 50.13 & 45.67 & 3.03 & 16.76 & 30.57 & 0.64 & 0.35 & 2.23 & 6.23 & 5.64 & 1.95 & 0.13 & 0.27 & 0.68 & 1.43 \\
\hline R53 & 29.76 & 19.09 & 9.99 & 1.91 & 6.41 & 0.16 & 0.15 & 2.90 & 2.03 & 7.44 & 6.92 & 0.16 & 0.50 & 2.41 & 0.68 \\
\hline DH Mansholt & 53.62 & 43.00 & 7.73 & 5.72 & 14.97 & 0.52 & 0.19 & 9.59 & 1.68 & 16.06 & 5.66 & 0.12 & 0.61 & 1.33 & 2.89 \\
\hline H327 & 26.64 & 19.46 & 6.04 & 3.78 & 7.43 & 0.35 & 0.18 & 5.62 & 1.07 & 4.81 & 2.72 & 0.16 & 0.42 & 2.73 & 1.14 \\
\hline H149 & 40.89 & 34.64 & 4.92 & 7.20 & 17.33 & 0.42 & 0.24 & 4.92 & 1.94 & 9.79 & 2.68 & 0.07 & 0.47 & 1.70 & 1.33 \\
\hline Liropa & 9.67 & 3.30 & 6.31 & 0.57 & 1.08 & 0.02 & 0.15 & 0.67 & 0.32 & 1.07 & 2.72 & 0.12 & 0.35 & 3.11 & 0.07 \\
\hline S30 & 23.06 & 19.13 & 3.70 & 5.47 & 6.65 & 0.13 & 0.15 & 4.21 & 0.83 & 7.16 & 1.96 & 0.17 & 0.33 & 1.24 & 0.24 \\
\hline Campala & 24.76 & 15.29 & 9.47 & 1.66 & 5.06 & 0.00 & 0.19 & 2.14 & 0.78 & 7.13 & 5.50 & 0.06 & 0.32 & 3.59 & 0.00 \\
\hline Grizzly & 34.74 & 27.59 & 6.44 & 4.26 & 8.10 & 0.04 & 0.24 & 3.60 & 2.31 & 13.30 & 3.90 & 0.14 & 0.37 & 2.03 & 0.71 \\
\hline Mendel & 25.96 & 19.83 & 6.31 & 3.32 & 6.45 & 0.02 & 0.15 & 2.03 & 2.13 & 8.15 & 3.81 & 0.15 & 0.35 & 2.00 & 0.72 \\
\hline DH Samourai & 29.85 & 24.23 & 4.61 & 5.40 & 7.20 & 0.05 & 0.19 & 4.96 & 1.32 & 10.51 & 2.43 & 0.17 & 0.31 & 1.70 & 1.01 \\
\hline G53 & 41.47 & 35.72 & 4.55 & 8.15 & 13.62 & 0.54 & 0.36 & 3.78 & 3.58 & 13.84 & 2.32 & 0.07 & 0.27 & 1.89 & 1.20 \\
\hline H113 & 44.62 & 34.36 & 7.57 & 4.58 & 17.70 & 0.30 & 0.26 & 7.62 & 0.78 & 7.70 & 4.55 & 0.29 & 0.24 & 2.49 & 2.70 \\
\hline Visby & 17.95 & 14.25 & 3.47 & 4.32 & 3.57 & 0.04 & 0.16 & 3.37 & 1.01 & 6.09 & 1.99 & 0.21 & 0.32 & 0.95 & 0.23 \\
\hline Express617 & 32.74 & 24.45 & 7.02 & 3.60 & 8.06 & 0.03 & 0.21 & 3.42 & 1.69 & 11.05 & 3.88 & 0.13 & 0.43 & 2.58 & 1.27 \\
\hline Oase & 23.74 & 19.27 & 3.78 & 5.71 & 6.34 & 0.09 & 0.17 & 3.46 & 1.43 & 7.77 & 2.29 & 0.23 & 0.29 & 0.97 & 0.69 \\
\hline L16 & 10.75 & 3.65 & 7.10 & 0.53 & 1.34 & 0.00 & 0.21 & 0.72 & 0.12 & 1.25 & 4.22 & 0.23 & 0.23 & 2.42 & 0.00 \\
\hline S14 & 47.73 & 41.48 & 5.49 & 7.67 & 12.81 & 0.22 & 0.23 & 9.61 & 1.42 & 17.20 & 2.02 & 0.15 & 0.31 & 3.00 & 0.76 \\
\hline Sollux & 58.87 & 49.41 & 7.43 & 6.64 & 15.84 & 0.29 & 0.29 & 9.11 & 2.85 & 21.02 & 4.06 & 0.19 & 0.51 & 2.66 & 2.03 \\
\hline L122 & 52.50 & 43.16 & 6.61 & 6.93 & 17.62 & 0.35 & 0.24 & 9.88 & 1.22 & 13.85 & 3.44 & 0.15 & 0.54 & 2.48 & 2.74 \\
\hline R140 & 29.90 & 21.18 & 6.22 & 3.65 & 9.23 & 0.65 & 0.17 & 4.15 & 0.71 & 6.27 & 4.72 & 0.09 & 0.36 & 1.04 & 2.51 \\
\hline H10 & 18.71 & 12.01 & 4.76 & 2.58 & 4.62 & 0.51 & 0.13 & 3.77 & 0.44 & 2.55 & 1.57 & 0.10 & 0.39 & 2.70 & 1.94 \\
\hline
\end{tabular}


Chapter IV

Table 11 Glucosinolate contents ( $\mu$ mol / g D.W.) of leaves of 23 Brassica napus genotypes on March $27^{\text {th }}$ 2012. Mean values of three to four replicates. See Table 2 for denominations of glucosinolates

\begin{tabular}{|c|c|c|c|c|c|c|c|c|c|c|c|c|c|c|c|}
\hline Genotype & Total & Aliphatic & Indolyl & $\mathrm{A} / \mathrm{I}$ & PRO & RAA & GNL & ALY & GNA & GBN & GBC & $4 \mathrm{OH}$ & $4 \mathrm{ME}$ & $\mathrm{NEO}$ & NAS \\
\hline Goe1991 & 14.04 & 8.08 & 2.92 & 2.96 & 2.78 & 0.00 & 0.33 & 2.49 & 0.08 & 2.41 & 1.85 & 0.00 & 0.07 & 1.00 & 0.29 \\
\hline Santana & 7.75 & 3.33 & 2.87 & 1.17 & 1.35 & 0.00 & 0.25 & 0.72 & 0.00 & 1.02 & 2.06 & 0.00 & 0.07 & 0.75 & 0.00 \\
\hline Н30 & 21.82 & 13.09 & 4.24 & 3.11 & 4.46 & 0.00 & 0.30 & 5.97 & 0.00 & 2.35 & 1.78 & 0.00 & 0.05 & 2.41 & 0.16 \\
\hline S3 & 48.25 & 36.36 & 1.71 & 25.23 & 21.89 & 0.39 & 0.18 & 1.52 & 6.38 & 6.00 & 1.42 & 0.00 & 0.05 & 0.25 & 0.67 \\
\hline DH Mansholt & 35.98 & 22.72 & 5.45 & 4.27 & 10.01 & 0.05 & 0.18 & 4.23 & 0.71 & 7.55 & 4.46 & 0.00 & 0.11 & 0.89 & 0.76 \\
\hline Н327 & 30.45 & 13.33 & 10.44 & 1.43 & 7.01 & 0.00 & 0.39 & 3.31 & 0.47 & 2.14 & 6.22 & 0.02 & 0.18 & 4.02 & 0.74 \\
\hline H149 & 26.80 & 17.99 & 3.27 & 6.08 & 8.52 & 0.05 & 0.24 & 2.62 & 0.75 & 5.80 & 2.72 & 0.00 & 0.09 & 0.46 & 0.23 \\
\hline Liropa & 9.80 & 3.01 & 4.65 & 0.69 & 1.23 & 0.00 & 0.26 & 0.31 & 0.14 & 1.08 & 2.87 & 0.00 & 0.10 & 1.68 & 0.22 \\
\hline S30 & 14.84 & 8.45 & 3.22 & 2.58 & 3.01 & 0.00 & 0.23 & 1.29 & 0.52 & 3.40 & 2.24 & 0.00 & 0.09 & 0.89 & 0.25 \\
\hline Campala & 25.68 & 13.97 & 6.29 & 2.24 & 6.26 & 0.00 & 0.28 & 2.68 & 0.39 & 4.38 & 4.21 & 0.00 & 0.06 & 2.02 & 0.35 \\
\hline Grizzly & 31.97 & 21.37 & 3.96 & 5.41 & 8.06 & 0.00 & 0.29 & 2.49 & 1.86 & 8.68 & 2.67 & 0.00 & 0.11 & 1.18 & 0.31 \\
\hline Mendel & 18.56 & 10.37 & 4.27 & 2.49 & 4.61 & 0.00 & 0.25 & 1.28 & 0.61 & 3.62 & 3.21 & 0.00 & 0.09 & 0.98 & 0.25 \\
\hline DH Samourai & 17.69 & 9.93 & 3.31 & 3.00 & 3.52 & 0.00 & 0.16 & 1.97 & 0.47 & 3.81 & 2.55 & 0.02 & 0.11 & 0.64 & 0.03 \\
\hline G53 & 28.33 & 17.25 & 5.24 & 3.40 & 7.14 & 0.42 & 0.20 & 1.62 & 1.46 & 6.41 & 3.97 & 0.00 & 0.06 & 1.21 & 0.22 \\
\hline H113 & 36.57 & 21.76 & 6.72 & 3.60 & 11.87 & 0.00 & 0.11 & 5.33 & 0.40 & 4.05 & 5.53 & 0.02 & 0.01 & 1.16 & 0.97 \\
\hline Visby & 21.24 & 13.80 & 3.11 & 4.68 & 5.55 & 0.00 & 0.23 & 3.11 & 0.57 & 4.33 & 2.54 & 0.00 & 0.07 & 0.50 & 0.11 \\
\hline Express617 & 24.65 & 14.82 & 4.63 & 3.32 & 6.44 & 0.00 & 0.30 & 2.32 & 0.87 & 4.89 & 2.69 & 0.00 & 0.10 & 1.57 & 0.34 \\
\hline Oase & 18.74 & 11.91 & 2.84 & 4.30 & 4.44 & 0.00 & 0.33 & 1.58 & 0.73 & 4.82 & 2.32 & 0.00 & 0.08 & 0.44 & 0.30 \\
\hline L16 & 5.68 & 1.82 & 2.70 & 0.71 & 0.64 & 0.00 & 0.32 & 0.35 & 0.00 & 0.51 & 1.98 & 0.00 & 0.05 & 0.67 & 0.02 \\
\hline S14 & 47.60 & 33.52 & 4.32 & 8.23 & 10.39 & 2.53 & 0.24 & 5.30 & 1.31 & 13.74 & 1.97 & 0.00 & 0.08 & 2.27 & 0.30 \\
\hline Sollux & 64.32 & 43.06 & 7.67 & 5.97 & 15.56 & 0.16 & 0.22 & 7.45 & 1.94 & 17.73 & 4.21 & 0.00 & 0.20 & 3.26 & 0.91 \\
\hline L122 & 34.84 & 20.37 & 7.05 & 3.18 & 9.72 & 0.09 & 0.17 & 4.60 & 0.43 & 5.36 & 5.74 & 0.00 & 0.08 & 1.23 & 0.58 \\
\hline H65 & 12.22 & 6.71 & 2.61 & 2.90 & 2.04 & 0.00 & 0.34 & 0.89 & 0.88 & 2.55 & 2.14 & 0.01 & 0.08 & 0.38 & 0.56 \\
\hline
\end{tabular}


Chapter IV

Table 12 Glucosinolate contents ( $\mu$ mol / g D.W.) of leaves of 26 Brassica napus genotypes on April $17^{\text {th }}$ 2013. Mean values of three to four replicates. See Table 2 for denominations of glucosinolates

\begin{tabular}{|c|c|c|c|c|c|c|c|c|c|c|c|c|c|c|c|}
\hline Genotype & Total & Aliphatic & Indolyl & $\mathrm{A} / \mathrm{I}$ & PRO & RAA & GNL & ALY & GNA & GBN & GBC & $4 \mathrm{OH}$ & $4 \mathrm{ME}$ & $\mathrm{NEO}$ & NAS \\
\hline Goe1991 & 11.36 & 7.28 & 4.02 & 1.81 & 2.84 & 0.00 & 0.26 & 3.01 & 0.12 & 1.05 & 2.88 & 0.05 & 0.24 & 0.84 & 0.07 \\
\hline Gaoyou & 27.15 & 22.78 & 3.88 & 5.87 & 7.95 & 0.03 & 0.23 & 2.64 & 1.14 & 10.79 & 3.15 & 0.08 & 0.21 & 0.43 & 0.49 \\
\hline Santana & 6.93 & 2.97 & 3.96 & 0.75 & 1.09 & 0.00 & 0.19 & 0.61 & 0.07 & 1.02 & 2.86 & 0.03 & 0.19 & 0.87 & 0.00 \\
\hline Н30 & 17.32 & 14.03 & 3.28 & 4.28 & 5.08 & 0.00 & 0.22 & 5.00 & 0.08 & 3.65 & 1.96 & 0.05 & 0.13 & 1.14 & 0.00 \\
\hline S3 & 36.35 & 34.98 & 1.22 & 28.67 & 22.07 & 0.28 & 0.37 & 1.36 & 5.78 & 5.12 & 0.99 & 0.00 & 0.11 & 0.12 & 0.15 \\
\hline R53 & 20.78 & 16.12 & 4.40 & 3.66 & 5.59 & 0.19 & 0.11 & 2.21 & 1.42 & 6.69 & 3.55 & 0.09 & 0.22 & 0.54 & 0.26 \\
\hline DH Mansholt & 34.94 & 30.56 & 3.82 & 8.00 & 11.39 & 0.10 & 0.18 & 4.48 & 1.46 & 12.95 & 3.21 & 0.03 & 0.18 & 0.40 & 0.56 \\
\hline H327 & 29.67 & 25.59 & 3.65 & 7.01 & 10.63 & 0.11 & 0.22 & 5.44 & 1.64 & 7.55 & 2.74 & 0.09 & 0.19 & 0.63 & 0.43 \\
\hline H149 & 34.35 & 30.54 & 3.53 & 8.65 & 14.8 & 0.19 & 0.11 & 3.57 & 1.85 & 10.02 & 2.73 & 0.00 & 0.21 & 0.59 & 0.27 \\
\hline Liropa & 8.42 & 3.95 & 4.48 & 0.88 & 1.39 & 0.00 & 0.13 & 0.41 & 0.32 & 1.7 & 3.27 & 0.03 & 0.20 & 0.97 & 0.00 \\
\hline S30 & 17.83 & 15.90 & 1.93 & 8.24 & 5.31 & 0.00 & 0.18 & 2.50 & 0.93 & 6.98 & 1.41 & 0.03 & 0.19 & 0.30 & 0.00 \\
\hline Campala & 14.67 & 11.54 & 3.12 & 3.70 & 3.86 & 0.00 & 0.18 & 1.56 & 0.52 & 5.42 & 2.23 & 0.02 & 0.12 & 0.76 & 0.00 \\
\hline Grizzly & 25.58 & 23.45 & 2.04 & 11.50 & 6.72 & 0.00 & 0.22 & 2.07 & 2.10 & 12.37 & 1.40 & 0.04 & 0.16 & 0.44 & 0.06 \\
\hline Mendel & 20.68 & 18.02 & 2.56 & 7.04 & 6.35 & 0.00 & 0.22 & 1.38 & 1.89 & 8.18 & 1.97 & 0.05 & 0.16 & 0.38 & 0.10 \\
\hline DH Samourai & 20.76 & 18.95 & 1.71 & 11.08 & 5.83 & 0.00 & 0.12 & 2.59 & 1.22 & 9.19 & 1.23 & 0.06 & 0.12 & 0.30 & 0.10 \\
\hline G53 & 36.19 & 32.68 & 3.35 & 9.76 & 12.41 & 0.55 & 0.39 & 2.77 & 3.40 & 13.15 & 2.63 & 0.01 & 0.11 & 0.60 & 0.16 \\
\hline H113 & 34.97 & 29.33 & 4.61 & 6.36 & 14.10 & 0.12 & 0.22 & 5.53 & 0.98 & 8.38 & 3.72 & 0.08 & 0.11 & 0.70 & 1.02 \\
\hline Visby & 17.02 & 15.01 & 2.00 & 7.51 & 5.01 & 0.00 & 0.20 & 2.25 & 1.01 & 6.54 & 1.57 & 0.03 & 0.11 & 0.29 & 0.00 \\
\hline Express & 24.68 & 22.46 & 2.15 & 10.45 & 7.62 & 0.03 & 0.18 & 2.00 & 1.79 & 10.84 & 1.61 & 0.03 & 0.14 & 0.37 & 0.07 \\
\hline Oase & 17.09 & 15.46 & 1.47 & 10.52 & 5.17 & 0.02 & 0.21 & 1.93 & 1.25 & 6.89 & 1.11 & 0.06 & 0.13 & 0.16 & 0.16 \\
\hline L16 & 6.93 & 3.11 & 3.69 & 0.84 & 1.18 & 0.00 & 0.20 & 0.42 & 0.05 & 1.27 & 2.72 & 0.07 & 0.13 & 0.77 & 0.13 \\
\hline S14 & 34.00 & 31.67 & 2.25 & 14.08 & 10.81 & 0.04 & 0.26 & 5.34 & 1.60 & 13.63 & 1.37 & 0.04 & 0.13 & 0.71 & 0.08 \\
\hline Sollux & 45.33 & 39.65 & 4.87 & 8.14 & 12.59 & 0.17 & 0.09 & 5.60 & 2.13 & 19.06 & 3.29 & 0.04 & 0.31 & 1.22 & 0.82 \\
\hline L122 & 39.68 & 35.14 & 3.91 & 8.99 & 15.43 & 0.21 & 0.20 & 5.48 & 0.89 & 12.94 & 2.92 & 0.03 & 0.27 & 0.68 & 0.63 \\
\hline R140 & 31.86 & 25.62 & 5.38 & 4.76 & 11.59 & 0.99 & 0.20 & 4.13 & 0.71 & 8.00 & 5.05 & 0.10 & 0.09 & 0.15 & 0.86 \\
\hline H10 & 19.91 & 14.50 & 4.73 & 3.07 & 6.74 & 0.23 & 0.16 & 3.41 & 0.50 & 3.46 & 3.47 & 0.04 & 0.13 & 1.10 & 0.68 \\
\hline
\end{tabular}




\section{Discussion}

The results of both field experiments showed considerable variability between the tested genotypes in the level of stem infestation by $C$. napi, while there was only little variability in the level of infestation by $C$. pallidactylus. This study has successfully demonstrated the potential of resynthesized lines of $B$. napus as potential sources of resistance against the stem mining pest $C$. napi and identified the resynthesized line S30 to be the least infested of the genotypes tested, including commercial cultivars.

Susceptibility to oviposition by C. napi: There was a considerable variability between genotypes in the number of eggs deposited by $C$. napi at the early stage of the oviposition period. Significantly lower numbers of eggs were laid on the resynthesized line H113 and the cultivars Sollux and Grizzly compared to the resynthesized line S3. At this stage of oviposition, the number of C. napi eggs in S30 did not significantly differ from the other tested genotypes. Although numbers of eggs laid on H113, Sollux and Grizzly was relatively low, the level of infestation by $C$. napi larvae was on an intermediate or high level. The number of eggs was assessed at only one early sampling date when the infestation period of $C$. napi was not was finished yet. The course of egg-deposition into selected $B$. napus genotypes over the entire infestation period of $C$. napi has been specified in chapter III. In chapter III, the cultivar Sollux was also less preferred for oviposition by C. napi at the early period of oviposition, while at a later sampling date it contained a high number of eggs in stems.

Plant growth stages and the length of stems are known to have an influence on the host plant selection of herbivorous insects (Sarfraz et al. 2006). In this study there was no evidence that growth stage was in itself associated with the resistance. Resynthesized line L16 and cultivar Santana were both one point on the BBCH growth stage scale more advanced than the other genotypes, but they did not significantly differ in the number of deposited $C$. napi eggs. However, plants with a stem length exceeding $22 \mathrm{~cm}$ are less preferred by females of $C$. napi for egg-laying (Buechi 1996). The present study indicated that at the early stage of the oviposition period, when the stem length of all genotypes was shorter than $22 \mathrm{~cm}$, the number of eggs was positively dependent upon the length of stems, while at peak abundance of eggs, the number of eggs was negatively dependent upon stem length of genotypes (chapter III). In chapter III, at peak abundance of eggs, stems of several genotypes were already longer than $22 \mathrm{~cm}$, therefore growers preferably should plant cultivars showing a delayed elongation growth at the beginning of the growing season (short stems), but subsequently high elongation growth rates. However, cultivars with high growth rates of stems have been found to increase 
the risk of stem splitting (Lerin 1993). Additionally, the stem length can vary with annual climatic condition (Ballanger 1987), so it may be unwise to rely solely on this trait for resistance.

Biochemical plant traits such as secondary metabolites and volatiles are important for host acceptance of herbivorous insects (Mayer 2004; Schoonhoven et al. 2005). Glucosinolates have been shown to trigger oviposition of crucifer-feeding insects (Renwick et al. 1992; Van Loon et al. 1992; Chew and Renwick 1995). They can repel or deter a wide range of generalist herbivores from brassicaceous plants (Chew 1988; Giamoustaris and Mithen 1995). Even specialist insects are not completely immune to the defense compounds of brassicaceous host plants (Ali and Agrawal 2012). Individual glucosinolates can cause repulsion or deterrence of specialist insect pests in crucifer plants (Waligora and Krzymanska 1995; Siemens and Mitchelolds 1996; Eickermann 2011). In the present study, although the glucosinolate profiles of the stems differed significantly between genotypes, the number of $C$. napi eggs was not associated with the stem glucosinolate profile.

However, the number of $C$. napi eggs was significantly dependent upon contents of individual stem glucosinolates. The number of $C$. napi eggs was significantly negative dependent upon the aliphatic glucosinolate ALY and the aromatic glucosinolate NAS and significantly positive dependent upon the aliphatic glucosinolate GNL. Tansey and Dosdall (2011) reported that oviposition by cabbage root fly (D. radicum) was negatively dependent upon the indolyl glucosinolate NEO. In a field experiment, Meier (unpubl. MSc thesis, Goettingen 2013) found a negative relationship between the infestation by pollen beetle (Meligethes aeneus (F.)) and the content of NEO in buds of different B. napus genotypes. Similarly, a negative relationship was observed between the infestation by cabbage stem flea beetle (P. chrysocephala) and cabbage flea beetles (Phyllotreta spp.) and the indolyl content in oilseed rape seeds (Plachká et al. 2006). Huang and Renwick (1994) reported that the behavioral response of small white butterfly (Pieris rapae L.) to indolyl and aromatic glucosinolates was more marked than to aliphatic glucosinolates. There is little information in the literature about the behavioral effects of the aliphatic glucosinolate ALY. Huang and Renwick (1994) reported that oviposition by the green-veined white butterfly (Pieris napi (L.)) was strongly influenced by the aliphatic glucosinolates. In the field experiment presented in chapter III, the number of $C$. napi eggs at peak oviposition was positively dependent upon the content of ALY and NEO. These contrasting results might be explained by the number of eggs, which was assessed at peak oviposition and not at the early stage of the oviposition period. 
It might be also possible that glucosinolate contents have altered in response to the oviposition by $C$. napi, because glucosinolate biosynthesis in brassicaceous plants can be induced by herbivory (Bodnaryk 1992; Bartlet et al. 1999).

The content of primary plant nutrients has been found to affect oviposition of herbivores in canola (Blake et al. 2010). In this study, the number of eggs deposited by $C$. napi into main stems at the early stage of the oviposition period in 2012 was not significantly dependent upon carbon content, nitrogen content and C:N ratio of stems in 2013. Carbon contents and nitrogen contents were not assessed from plant samples in 2012.

Larval infestation by C. napi and C. pallidactylus and glucosinolates: In the field experiments of 2012 and 2013, the resynthesized line S30 contained the lowest number of $C$. napi larvae. The low number of $C$. napi larvae in S30 may have resulted from lower eggdeposition or from increased egg and larval mortality, indicating antixenosis or antibiosis resistance in this line. Similar results have been obtained in the semi-field and in the open field experiment presented in chapter II and chapter III. In 2012 and 2013, the number of $C$. pallidactylus larvae did not differ significantly between the genotypes. In contrast, Eickermann (2011) found lower numbers of C. pallidactylus larvae in the resynthesized lines L122 and L16 compared to other B. napus genotypes. In our study, the number of $C$. pallidactylus larvae in L122 was on a low level in 2012, while it was higher in 2013. The level of infestation in L16 was not reduced in both years. These inconsistencies might be due to varying numbers of side shoots of B. napus plants. Eickermann and Ulber (2011) found, that the number of $C$. pallidactylus larvae increases with increasing number of side shoots per main stem of oilseed rape. In our study, the number of $C$. pallidactylus larvae in side shoots was not assessed.

Secondary metabolites might affect the host plant preference of herbivorous insects (Mayer 2004; Schoonhoven et al. 2005). Even though the glucosinolate profiles of stems differed significantly between the tested genotypes, the number of $C$. napi larvae was not associated with the stem glucosinolate profile. Additionally, no relationship was found between the number of larvae and individual groups and single compounds of glucosinolates in stems. Herbivore damage to $B$. napus by $P$. chrysocephala can systemically induce changes in the glucosinolate profile (Bartlet et al. 1999). Thus, larval feeding by both stem-boring species might have altered the glucosinolate contents of stems. This might explain why the glucosinolates were not associated with the number of $C$. napi larvae. However, results obtained in chapter III indicated that the number of larvae and larval performance of $C$. napi were not affected by glucosinolate contents of infested stems later in the growing season. 
Performance of C. napi and C. pallidactylus larvae, morphological plant traits and plant nutrients: Egg deposition by $C$. napi and larval feeding within the stem pith tissue may result in considerable disruption to stem growth (Alford et al. 2003). Phenotypic differences between tested genotypes were in length of full-grown stem in 2013, while in 2012 no differences were found. The resynthesized line H30, which had the shortest stem showed a high number of $C$. napi larvae, while the resynthesized line S14 and the cultivar Visby, which showed the longest full-grown stem also displayed an intermediate number of $C$. napi larvae. In 2013, the length of full-grown stems was not associated with the number of $C$. napi larvae. However, the length of the full-grown stems was not assessed from non-infested control plants. The variability found in stem length was probably related to the variability in plant development rate. Additionally, plant development rates may have been affected by environmental factors (McNaughton 1983). In 2012, the full-grown stems of genotypes tested were shorter compared to full-grown stems in 2013. This might be due to the high infestation pressure of C. napi in 2012.

Some crucifer feeding insects preferentially attack cruciferous plants with larger amounts of biomass (Mustata and Mustata 2008). The biomass and dry biomass of above ground main stems showed no phenotypic differences between the genotypes tested, suggesting that stem biomass is unlikely to have an influence on infestation and performance of C. napi larvae.

The stem injury coefficient has been evaluated to determine the amount of larval feeding within the stems of the genotypes tested. In 2012, the stem injury coefficient showed no significant phenotypic differences, while in 2013, it showed significant differences. However, in 2013, the amount of feeding by C. napi larvae was significantly positive dependent upon the number of $C$. napi larvae. The lack of association between the number of larvae and the amount of larval feeding in 2012 may be due to the very high level of infestation by C. napi in 2012. In other studies, a positive relationship between the stem injury coefficient and the number of C. pallidactylus larvae (Eickermann 2011) and the number of $P$. chrysocephala larvae (Ferguson et al. 2003) has been found. In our study, the level of infestation by C. pallidactylus larvae did not significantly differ between the tested genotypes, indicating that genotypic differences were unlikely to have an influence on the amount of larval feeding by $C$. pallidactylus.

To determine resistance mechanism, the carbon and nitrogen content and the ratio between carbon and nitrogen in stems of tested genotypes were assessed. The content of nitrogen in plants has been reported to affect the oviposition preference of Ceutorhynchus 
obstrictus (Marsh.) (Blake et al. 2010). Further, the ratio of carbon and nitrogen in the leaves has been hypothesized to affect plant susceptibility to leaf-eating insects (Lincoln 1993). It has been also considered as a parameter to explain the performance of herbivorous insects on different host plants (Moeser and Vidal 2004). The carbon content, nitrogen content and C:N ratio of stems significantly differed between genotypes. However, the number of $C$. napi larvae in main stems was not significantly dependent upon carbon and nitrogen content and $\mathrm{C}: \mathrm{N}$ ratio of main stems. Therefore, in this study the difference in tissue concentrations of protein and carbohydrates between genotypes is unlikely to have a significant influence on infestation by $C$. napi. Additionally, the contents of plant nutrients can change during the growing season (Mattson 1980), but the contents of carbon and nitrogen of full-grown stems were not assessed in this study.

The multi-choice experiments of the present study have demonstrated that $B$. napus genotypes can have a significant influence on oviposition by $C$. napi and on the infestation and performance of $C$. napi larvae. The resynthesized line S30 was subject to a very low infestation rate by $C$. napi, while the infestation rate by $C$. pallidactylus was not as distinct as from C. napi. Thus, S30 is a potential source for breeding oilseed rape cultivars with resistance to $C$. napi. The glucosinolates within stems were not closely associated with antixenosis and antibiosis effects. Further studies should focus on determining the potential effect of further chemical traits, including volatile isothiocyanates, on host location and host acceptance by C. napi and C. pallidactylus.

\section{Acknowledgements}

I would like to thank Prof. Dr. H. C. Becker for providing seeds of rare genotypes, $\mathrm{H}$. Brandes, B. Olberg and U. Ammermann for glucosinolate analyses (Georg-August University) and M. Hervé for providing the macro for the multivariate statistic and further assistance (INRA, France). I would also like to thank the technical staff in the laboratory and in fields: D. Mennerich, E. Hodyl, M. Knobel, H. Reintke, G. Miotke and all student research assistants.

The study was funded by German Federal Ministry of Food, Agriculture and Consumer Protection (BMELV) and the Board of support for Private Plant Breeding in Germany (GFP). 


\section{References}

Alford DV, Nilsson C, Ulber B (2003) Insect pests of oilseed rape crops. In: DV Alford (Eds.), Biocontrol of oilseed rape pests. Blackwell Science Ltd., Oxford, pp 9-42.

Ali JG, Agrawal AA (2012) Specialist versus generalist insect herbivores and plant defense. Trends in Plant Science 17:293-302.

Ballanger Y (1987) Nuisibilité du charancon de la tige du colza (Ceutorrhynchus napi Gyll.). Phytoma 384:35-37.

Barker E, Rayens W (2003) Partial least squares for discrimination. Journal of Chemometrics 17:166-173.

Bartlet E, Kiddle G, Williams I, Wallsgrove R (1999) Wound-induced increases in the glucosinolate content of oilseed rape and their effect on subsequent herbivory by a crucifer specialist. Entomologia Experimentalis et Applicata 91:163-167.

Bartlet E, Parsons D, Williams IH, Clark SJ (1994) The influence of glucosinolates and sugars on feeding by the cabbage stem flea beetle, Psylliodes chrysocephala. Entomologia Experimentalis et Applicata 73:77-83.

Blake A, Dosdall L, Keddie B (2010) Plant nutrients and the spatiotemporal distribution dynamics of Ceutorhynchus obstrictus (Coleoptera: Curculionidae) and its parasitoids. Environmental Entomology 39:1195-1205.

Bodnaryk RP (1992) Effects of wounding on glucosinolates in the cotyledons of oilseed rape and mustard. Phytochemistry 31:2671-2677.

Buechi R (1996) Eiablage des Rapsstengelruesslers Ceutorhynchus napi Gyll., in Abhaengigkeit der Stengellaenge bei verschiedenen Rapssorten. Anzeiger fuer Schaedlingskunde, Pflanzenschutz, Umweltschutz 69:136-139.

Cárcamo H, Olfert O, Dosdall L, Herle C, Beres B, Soroka J (2007) Resistance to cabbage seedpod weevil among selected Brassicaceae germplasm. The Canadian Entomologist 139:658-669.

Chen Y-Z, Lin L, Wang C-W, Yeh C-C, Hwang S-Y (2004) Response of two Pieris (Lepidoptera: Pieridae) species to fertilization of a host plant. Zoological Studies 43:778-786.

Chew F (1988) Biological effects of glucosinolates. In: GC Horace (Eds.), Biologically active natural products: potential use in agriculture. CRS, Danvers, pp 155-181.

Chew F, Renwick J (1995) Host plant choice in Pieris butterflies. In: RT Carde and WJ Bell (Eds.), Chemical Ecology of Insects 2. Chapman and Hall, New York, Victoria, Scarborough, Col. Polanco, pp 214-238. 
Cleemput S, Becker HC (2012) Genetic variation in leaf and stem glucosinolates in resynthesized lines of winter rapeseed (Brassica napus L.). Genetic Resources and Crop Evolution 59:539-546.

Dechert G, Ulber B (2004) Interactions between the stem-mining weevils Ceutorhynchus napi Gyll. and Ceutorhynchus pallidactylus (Marsh.) (Coleoptera: Curculionidae) in oilseed rape. Agricultural and Forest Entomology 6:193-198.

Deubert K-H (1952) Ueber das durch die Eiablage von Ceutorrhynchus napi Gyll. (Col. Curc.) verursachte histologische Schadbild an Winterraps. Wissenschaftliche Zeitschrift der Martin-Luther-Universitaet Halle-Wittenberg 2:203-205.

Deubert K-H (1955) Beitraege zu den Beziehungen zwischen Ceutorrhynchus napi Gyll. (Col. Curc.) und Winterraps hinsichtlich der Gallenbildung mit Ovarienuntersuchungen an verschiedenen Ceutorrhynchus-Arten. Wissenschaftliche Zeitschrift der Martin-Luther-Universitaet Halle-Wittenberg 5:909-932.

Diedrichsen E, Sacristan M (1991) Resynthesis of amphidiploid Brassica species and their clubroot disease reaction. Proc Rapeseed Cong, Saskatoon, Canada, 9-11 July 1991, 1: 274-279.

Dosse G (1951) Der grosse Kohltriebruessler Ceuthorrhynchus napi Gyll. Biologie, Schadenauftreten und Bekaempfung unter besonderer Beruecksichtigung der " Gallbildung" an Kohlpflanzen: Mit 41 Abb.. Zeitschrift fuer Angewandte Entomologie 32:32-566.

Eickermann M (2011) Resynthesized lines and cultivars of Brassica napus L. provide sources of resistance to the cabbage stem weevil (Ceutorhynchus pallidactylus (Mrsh.)). Bulletin of Entomological Research 101:287-294.

Eickermann M, Ulber B (2011) Effect of plant architecture on infestation of Brassica genotypes by cabbage stem weevil, Ceutorhynchus pallidactylus (Mrsh.). Proc Intern Rapeseed Cong, Prague, Czech Republic, 5-9 June 2011, CD-Rom.

Fahey JW, Zalcmann AT, Talalay P (2001) The chemical diversity and distribution of glucosinolates and isothiocyanates among plants. Phytochemistry 56:5-51.

Feeny P (1977) Defensive ecology of the cruciferae. Annals of the Missouri Botanical Garden 64:221-234.

Feng J, Long Y, Shi L, Shi J, Barker G, Meng J (2012) Characterization of metabolite quantitative trait loci and metabolic networks that control glucosinolate concentration in the seeds and leaves of Brassica napus. New Phytologist 193:96-108. 
Fenwick G, Heaney R (1983) Glucosinolates and their breakdown products in cruciferous crops, foods and feedingstuffs. Food Chemistry 11:249-271.

Ferguson AW, Klukowski Z, Walczak B, Clark SJ, Mugglestone MA, Perry JN, Williams IH (2003) Spatial distribution of pest insects in oilseed rape: implications for integrated pest management. Agriculture, Ecosystems and Environment 95:509-521.

Frauen M (2011) Zuchtziele. In: O Christen und W Friedt (Eds.), Winterraps, das Handbuch fuer Profis. DLG, Frankfurt am Main, pp 25-30.

Freier B, Sellmann J, Schwarz J, Klocke B, Kehlenbeck H, Zornbach W (2014) Netz Vergleichsbetriebe Pflanzenschutz-Jahresbericht 2012 - Analyse der Ergebnisse der Jahre 2007 bis 2012. JKI Berichte 172:1-111.

Friedt W (2011) Ausgangsmaterial. In: O Christen und W Friedt (Eds.), Winterraps, das Handbuch fuer Profis. DLG, Frankfurt am Main, pp 20-25.

Geladi P, Kowalski B (1986) Partial least squares regression: a tutorial. Analytica Chimica Acta: 185:1-17.

Giamoustaris A, Mithen R (1995) The effect of modifying the glucosinolate content of leaves of oilseed rape (Brassica napus ssp. oleifera) on its interaction with specialist and generalist pests. Annals of Applied Biology 126:347-363.

Girke A (2002) Neue Genpools aus resynthetisiertem Raps (Brassica napus L.) fuer die Hybridzuechtung. Dissertation, Georg-August Universitaet, Goettingen.

Girke A, Schierholt A, Becker HC (2012). Extending the rapeseed genepool with resynthesized Brassica napus L. I: genetic diversity. Genetic Resources and Crop Evolution 59:1441-1447.

Guenthart E (1949) Beitraege zur Lebensweise und Bekaempfung von Ceutorrhynchus quadridens Panz. und Ceutorrhynchus napi Gyll. mit Beobachtungen an weiteren Kohl- und Rapsschaedlingen. Mitteilungen der Schweizerischen Entomologischen Gesellschaft 22:441-591.

Gullan PJ, Cranston PS (2005) The insects - an outline of entomology. Blackwell, Malden, Oxford, Victoria.

Halkier BA, Gershenzon J (2006) Biology and biochemistry of glucosinolates. Annual Review of Plant Biology 57:303-333.

Hopkins RJ, van Dam NM, van Loon JJA (2009) Role of glucosinolates in insect-plant relationships and multitrophic interactions. Annual Review of Entomology 54:57-83.

Huang X, Renwick J (1994) Relative activities of glucosinolates as oviposition stimulants for Pieris rapae and P. napi oleracea. Journal of Chemical Ecology 20:1025-1037. 
Lancashire PD, Bleiholder H, Boom T, Langelueddeke P, Stauss R, Weber E, Witzenberger A (1991) A uniform decimal code for growth stages of crops and weeds. Annals of Applied Biology 119:561-601.

Le Pape H, Bronner R (1987) The effects of Ceutorhynchus napi (Curculionidae, Coleoptera) on stem tissue of Brassica napus var. oleifera. In: V Labeyrie, G Fabres and D Lachaise (Eds.), Insect-plants. Dr W Junk, Dordrecht, pp 207-212.

Lerin J (1993) Influence of the growth rate of oilseed rape on the splitting of the stem after an attack of Ceutorhynchus napi Gyll.. IOBC WPRS BULLETIN 16 (9):160-163.

Lincoln D (1993) The influence of plant carbon dioxide and nutrient supply on susceptibility to insect herbivores. Vegetatio 104:273-280.

Mattson WJ (1980) Herbivory in relation to plant nitrogen content. Annual Review of Ecology and Systematics 11:119-161.

Mayer AM (2004) Resistance to herbivores and fungal pathogens: variations on a common theme? A review comparing the effect of secondary metabolites, induced and constitutive, on herbivores and fungal pathogens. Israel Journal of Plant Sciences 52:279-292.

McNaughton SJ (1983) Compensatory plant growth as a response to herbivory. Oikos 40:329336.

Mithen R (1992) Leaf glucosinolate profiles and their relationship to pest and disease resistance in oilseed rape. Euphytica 63:71-83.

Mithen R (2001) Glucosinolates-biochemistry, genetics and biological activity. Plant Growth Regulation 34:91-103.

Moeser J, Vidal S (2004) Response of larvae of invasive maize pest Diabrotica virgifera virgifera (Coleoptera: Chrysomelidae) to carbon/nitrogen ratio and phytosterol content of European maize varieties. Journal of Economic Entomology 97:1335-1341.

Mrowczynski M (1998) Studies on pest damage of cultivars and lines of winter oilseed rape. IOBC WPRS BULLETIN 21 (5):153-154.

Mustata G, Mustata M (2009) The species. Biosemiotic dimensions. Entomofagii şi Rolul lor în Păstrarea Echilibrului Natural 2008:37-61.

Nuss H (2004) Einfluss der Pflanzedichte und -architektur auf Abundanz und innnerpflanzliche Verteilung staengelminierender Schadinsekten in Winterraps. Dissertation, Georg-August Universitaet, Goettingen.

Olsson G, Ellerstrom S, Tsunoda S, Hinata K, Gomez-Campo C (1980) Polyploidy breeding in Europe. Brassica Crops and Wild Allies:167-190. 
Plachká E, Kolovrat O, Vrbovský V (2006) The influence of glucosinolate content variability in the seeds and green matter of winter oilseed rape on the attack by pests. IOBC WPRS BULLETIN 29 (7):99-101.

Renwick JAA (2002) The chemical world of crucivores: lures, treats and traps. Entomologia Experimentalis et Applicata 104:35-42.

Renwick JAA, Radke CD, Sachdev-Gupta K, Staedler E (1992) Leaf surface chemicals stimulating oviposition by Pieris rapae (Lepidoptera: Pieridae) on cabbage. Chemoecology 3:33-38.

Rodman JE, Karol KG, Price RA, Sytsma KJ (1996) Molecules, morphology, and dahlgren's expanded order capparales. Systematic Botany 21:289-307.

Rusch A, Valantin-Morison M, Sarthou J, Roger-Estrade J (2013) Effect of crop management and landscape context on insect pest populations and crop damage. Agriculture, Ecosystems and Environment 166:118-125.

Rygulla W, Snowdon R, Eynck C, Koopmann B, von Tiedemann A, Luehs W, Friedt W (2007) Broadening the genetic basis of Verticillium longisporum resistance in Brassica napus by interspecific hybridization. Phytopathology 97:1391-1396.

Sarfraz M, Dosdall L, Keddie B (2006) Diamond-back moth - host plant interactions: implications for pest management. Crop Protection 25:625-639.

Schmutterer H (1956) Zur Lebensweise und Bekaempfung des Großen Rapsstengelruesslers Ceutorrhynchus napi (Gyll.). Zeitschrift fuer Angewandte Entomologie 39:302-315.

Schoonhoven LM, van Loon JJA, Dicke M (2005) Insect-plant biology. Oxford University Press, Oxford.

Seyis F, Friedt W, Luehs W (2001) Resynthese-Raps (Brassica napus L.) als genetische Ressource fuer die Qualitaets-und Ertragszuechtung. Schriften zu Genetischen Ressourcen 16:91-112.

Siemens DH, Mitchelolds T (1996) Glucosinolates and herbivory by specialists (Coleoptera: Chrysomelidae, Lepidoptera: Plutellidae): consequences of concentration and induced resistance. Environmental Entomology 25:1344-1353.

Snowdon RJ (2007) Cytogenetics and genome analysis in Brassica crops. Chromosome Research 15:85-95.

Snowdon RJ, Friedt W (2004) Molecular markers in Brassica oilseed breeding: current status and future possibilities. Plant Breeding 123:1-8.

Staley JT, Stewart-Jones A, Pope TW, Wright DJ, Leather SR, Hadley P, Rossiter JT, van Emden HF, Poppy GM (2010) Varying responses of insect herbivores to altered plant 
chemistry under organic and conventional treatments. Proceedings of the Royal Society B: Biological Sciences 277:779-786.

Tansey JA, Dosdall LM (2011) Differential responses by some insect pests to novel insectresistant Brassica napus L.. Proc Intern Rapeseed Cong, Prague, Czech Republic, 5-9 July 2011, CD-ROM.

Thieme T, Heimbach U, Mueller A (2010) Chemical control of insect pests and insecticide resistance in oilseed rape. In: IH Williams (Eds.), Biocontrol-based integrated management of oilseed rape pests. Springer Science and Business Media B.V., Dordrecht, Heidelberg, London, New York, pp 313-336.

Thies W (1977) Analysis of glucosinolates in seeds of rapeseed (Brassica napus L.): concentration of glucosinolates by ion exchanges. Zeitschrift fuer Pflanzenzuechtung 79:331-335.

Uddin MM, Ulrichs C, Tokuhisa JG, Mewis I (2009) Impact of glucosinolate structure on the performance of the crucifer pest Phaedon cochleariae (F.). Journal of Applied Botany and Food Quality 82:108-113.

Van Loon JJA, Blaakmeer A, Griepink FC, van Beek TA, Schoonhoven LM, de Groot A (1992) Leaf surface compound from Brassica oleracea (Cruciferae) induces oviposition by Pieris brassicae (Lepidoptera: Pieridae). Chemoecology 3:39-44.

Velasco L, Becker HC (2000) Variability for seed glucosinolates in a germplasm collection of the genus Brassica. Genetic Resources and Crop Evolution 47:231-238.

Waligora D, Krzymanska J (1995) Biological activity of glucosinolates isolated from rape Brassica napus L. to some insects. Proc Rapeseed Cong, Cambridge, United Kingdom, 4-7 July 1995, 9:1022-1024.

Williams IH (2010) The major insect pests of oilseed rape in Europe and their management: an overview. In: IH Williams (Eds.), Biocontrol-based integrated management of oilseed rape pests. Springer Science and Business Media B.V., Dordrecht, Heidelberg, London, New York, pp 1-43. 
Chapter V

\section{CHAPTER V}

\section{General discussion}

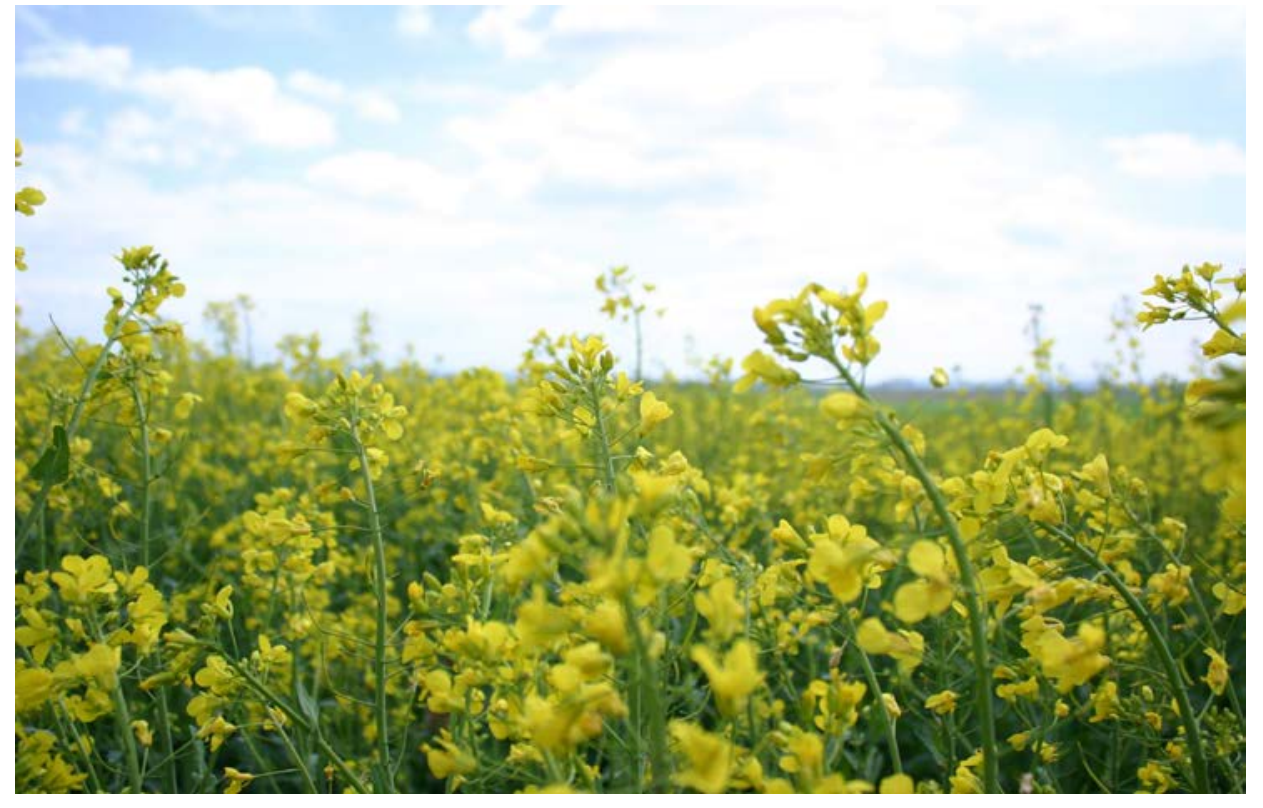


During its long growing season oilseed rape is attacked by a wide range of insect pests. Infestation by rape stem weevil (Ceutorhynchus napi Gyll.) and cabbage stem weevil (Ceutorhynchus pallidactylus (Marsh.)) can cause major economic damage (Alford et al. 2003). At present, the control of these insect pests strongly relies on synthetic insecticides (Thieme et al. 2010; Williams 2010). There is an urgent need for oilseed rape cultivars that are genetically resistant to C. napi, C. pallidactylus and other insect pests as part of integrated pest management systems to minimize the number of insecticide applications. In Europe, over-reliance on insecticide use has led to increasing incidence of insecticide resistance in oilseed rape pests (Hansen 2003; Derron et al. 2004; Zimmer and Nauen 2011; Zimmer et al. 2014). Today pollen beetle (Meligethes aeneus (F.)) is resistant to pyrethroid insecticides throughout Germany (Heimbach and Mueller 2013; Henning 2013).

Resistant cultivars could provide an important element in integrated pest management systems (Gullan and Cranston 2005) and are important targets in oilseed rape breeding (Friedt 2011). In the past, only few studies have been conducted to screen brassicaceous genotypes for insect resistance traits (Renwick 2002; Eickermann 2011; Tansey and Dosdall 2011). In two such studies, only minor variation in weevil infestation was found amongst the cultivars and lines tested (Mrowczynski 1998; Dechert and Ulber 2004). The use of resynthesized lines of oilseed rape presents a potential opportunity to break this impasse. Resynthesized lines are developed by interspecific crossing of the two progenitor species of B. napus, Brassica oleracea L. and Brassica rapa L.. They are being produced to broaden the genetic variation available to breeders of oilseed rape (Olsson et al. 1980; Girke et al. 2012). Several studies have reported the potential of resynthesized lines as sources of traits to improve resistance to disease (Diederichsen and Sacristan 1991; Rygulla et al. 2007) and resistance to insect pests (Seyis et al. 2001; Eickermann 2011).

In this study, the susceptibility of $30 \mathrm{~B}$. napus genotypes showing a broad genetic variability to infestation by the specialist stem weevils $C$. napi and C. pallidactylus was determined for the first time. Our investigations have successfully demonstrated the potential of resynthesized lines of $B$. napus as potential sources of resistance against the stem mining pest C. napi. To identify plant factors determining host location, host acceptance and larval performance of C. napi and C. pallidactylus, metabolic compounds and morphological plant traits were assessed. 


\section{Responses of $C$. napi and $C$. pallidactylus to plant genotypes}

Oviposition by C. napi: The results obtained in open field and laboratory experiments indicated considerable variability in acceptance of accessions tested for oviposition. The study identified the resynthesized line S30 to be the least infested among the genotypes tested, including lines and cultivars. There was considerable variability both within and between genotypes in the number of $C$. napi eggs found in main stems. The fewest eggs were consistently recorded in the resynthesized line S30 (open field and laboratory, chapter III). The low level of oviposition indicated antixenosis resistance in S30 to C. napi and suggests that S30 is likely to be a useful source of resistance traits for oilseed rape.

Effect of glucosinolates on oviposition by C. napi: Glucosinolates have been shown to affect host acceptance of crucifer-feeding insects (Mayer 2004; Schoonhoven et al. 2005). Several studies revealed that the content and composition of glucosinolates can trigger oviposition of insects (Renwick et al. 1992; Van Loon et al. 1992; Chew and Renwick 1995). On the other hand, the presence of glucosinolates in brassicaceous plants has been found to serve as defense compounds against non-specialist insects (Feeny 1977; Giamoustaris and Mithen 1995). However, even specialist insects are not completely immune to the defense compounds of brassicaceous host plants (Ali and Agrawal 2012).

Resynthesized lines of oilseed rape provide genetic resources for modifying the profile of glucosinolates (Cleemput and Becker 2012). The results obtained in an open field experiment indicated considerable variability in the glucosinolate profiles of non-infested stems among the material tested, including resynthesized lines and cultivars (open field, chapter III).

Glucosinolates are catalyzed by the endogenous enzyme myrosinase following cell disruption (Fenwick and Heaney 1983; Hopkins et al. 2009), while myrosinase is spatially separated from glucosinolates in non-disrupted cells (Mithen 1992, 2001). Our results showed that the number of $C$. napi eggs per stem at peak oviposition was positively dependent on the content of the glucosinolates glucoalyssin (ALY), gluconasturtiin (NAS) and glucobrassicanapin (GBN) and less distinct on glucobrassicin (GBC) and neoglucobrassicin (NEO), as assessed in non-infested stems (open field, chapter III). The genotype with the lowest number of $C$. napi eggs, the resynthesized line S30, showed the lowest level of total glucosinolates in non-infested stems. The low concentration of glucosinolates is likely to play an important role in the antixenosis resistance of S30 against oviposition by C. napi, by causing this genotype not to be recognized as a favored host. Reduced herbivory by the 
specialist cabbage flea beetle (Phyllotreta cruciferae Goeze) at low glucosinolate concentrations in Brassica rapa L. was also observed by Siemens and Mitchelolds (1996). Similar results were reported by Giamoustaris and Mithen (1995): reduced levels of leave glucosinolates resulted in lower feeding damage by adult cabbage stem flea beetle (Psylliodes chrysocephala (L.)). In other studies, oviposition by cabbage root fly (Delia radicum (L.)) correlated positively with the content of gluconasturtiin in B. napus (Tansey and Dosdall 2011) and glucobrassicin in B. oleracea (Roessingh et al. 1992). Bartlet et al. (1994) reported that feeding by $P$. chrysocephala on artificial medium was stimulated by glucobrassicin and gluconasturtiin. There is little information in literature about the effect of the aliphatic glucosinolate glucoalyssin on host acceptance of crucifer-feeding insects. Huang and Renwick (1994) reported that the oviposition by the green-veined white butterfly (Pieris napi (L.)) was strongly stimulated by aliphatic glucosinolates.

Number and performance of C. napi and C. pallidactylus larvae: The results obtained from open field and semi-field experiments indicated considerable variability in the number of $C$. napi larvae per plant among the oilseed rape genotypes tested. The resynthesized line S30 showed fewer $C$. napi larvae in the main stems than the other tested genotypes. Further, it was consistently the last genotype in which any C. napi larvae were found (semi-field, chapter II; open field, chapter III \& IV). This low number of larvae may have resulted from reduced oviposition in S30, thereby providing further evidence of antixenosis resistance in this line. Antibiosis resistance affects herbivore performance and may result in delayed development, reduced weight or increased mortality (Sarfraz et al. 2006). There is no evidence for an increased mortality of eggs or larvae of $C$. napi, because larval mortality as reflected by the ratio between the number of eggs and larvae in stems did not significantly differ between the genotypes tested. On the contrary, the larval development time as reflected by the larval instar index was significantly prolonged in S30 compared to L16 (semi-field, chapter II) and H30 (open field, chapter III), thereby indicating antibiosis resistance to C. napi in S30.

The results obtained from open field and semi-field experiments indicated only limited variability in the number of $C$. pallidactylus larvae in main stems among the oilseed rape genotypes tested. However, similar to C. napi the larval abundance of C. pallidactylus in S30 was on a low level as well (open field, chapter IV; appendix Table 4). This finding was confirmed by Eickermann (2011) who found that the infestation by C. pallidactylus larvae in S30 was not significantly reduced to other tested resynthesized lines of oilseed rape.

Effect of glucosinolates on infestation by C. napi and C. pallidactylus larvae: In the present study, there was no evidence that the number of $C$. napi larvae in main stems was 
associated with the glucosinolate profile of non-infested stems (semi-field, chapter II). Our study also found that the number of larvae in main stems was not dependent upon stem glucosinolate profiles, as assessed at the early stage of oviposition (open field, chapter IV).

The relationships between the number of $C$. pallidactylus larvae and the glucosinolate profiles of leaves was not subjected to statistical analyses, because the number of larvae in main stems of the tested genotypes was not significantly different. Therefore, there is no evidence that the number of $C$. pallidactylus larvae was associated with the glucosinolate profiles of leaves (open field, chapter IV).

Effect of plant nutrients on oviposition by C. napi and infestation by C. napi and C. pallidactylus larvae: Plant nutrients such as nitrogen have been reported to affect host acceptance and performance of crucifer-feeding insects (Blake et al. 2010). The nitrogen and carbon content and the $\mathrm{C}: \mathrm{N}$ ratio of stems did significantly differ between the oilseed rape genotypes tested. However, the number of eggs deposited by C. napi at the early stage of oviposition was not significantly dependent upon the nitrogen and carbon content and C:N ratio of stems (open field, chapter IV). Similarly, the number of C. napi larvae was not significantly dependent upon the carbon and nitrogen content and $\mathrm{C}: \mathrm{N}$ ratio of stems (open field, chapter IV). Consequently, tissue concentrations of protein and carbohydrates are unlikely to have a significant influence on oviposition and larval infestation by C. napi. By contrast, oviposition by females of cabbage seed weevil (Ceutorhynchus obstrictus (Marsh.)) decreased with increasing nitrogen content in canola plants (Blake et al. 2010). Chen et al. (2004) reported that the nitrogen fertilization rate affected host acceptance by females of Pieris spp., which laid more eggs on highly fertilized plants compared to poorly fertilized plants of cabbage.

The relationships between the number of $C$. pallidactylus larvae and the carbon and nitrogen content of stems and C: $\mathrm{N}$ ratio of stems were not statistically analyzed because the number of C. pallidactylus larvae in main stems was not significantly different between genotypes. Therefore, there is no evidence that the number of $C$. pallidactylus larvae was associated with the concentrations of protein and carbohydrates in plant tissue (open field, chapter IV).

Effect of morphological plant traits on oviposition by C. napi and infestation by C. napi and C. pallidactylus larvae: Plant growth stage and the length of stems are known to have an influence on the oviposition preference of C. napi (Lerin 1993; Buechi 1996). In this study there was no evidence that plant growth stage was in itself associated with the 
resistance. The BBCH growth stage of the resynthesized line L16 and the cultivar Santana was more advanced than the other genotypes, but the number of eggs deposited by $C$. napi into these genotypes did not significantly differ from the other tested genotypes (open field, chapter IV). Similarly, the cultivar Oase and resynthesized line S30 were also more advanced by one point on the BBCH growth stage scale than the other genotypes tested, but more eggs were laid on Oase than on S30, which contained the fewest number of eggs (open field, chapter III). Buechi (1996) reported that stems which are longer than $22 \mathrm{~cm}$ are less preferred for oviposition by $C$. napi. The stem length is linked with growth stage, the main stem rapidly extending during the bud stage (BBCH 50 - 59) as can be seen in Table 2 in chapter III. Our data confirm the effect of stem length on oviposition by C. napi: at peak oviposition, the number of eggs deposited by females was significantly negative dependent upon the stem length. In addition, oilseed rape stems longer than $20 \mathrm{~cm}$ are less susceptible to stem splitting (Lerin 1993) and so the long stemmed trait may be valuable for tolerance to C. napi infestation as well as resistance to it. However, stem length can vary with annual weather conditions (Ballenger 1987), so it may be thoughtless to rely solely on this trait for resistance.

Differences in the stem biomass did not appear to have an influence on the infestation by C. napi (open field, chapter III).

The relationships between the number of $C$. pallidactylus larvae and morphological plant traits were not statistically analyzed because of non-significant differences between the numbers of $C$. pallidactylus larvae in main stems. Therefore, there is no evidence that the number of $C$. pallidactylus larvae was associated with the morphological plant traits assessed in this study (open field, chapter IV).

\section{Plant responses to $C$. napi infestation}

Pith tissue degeneration in the presence of C. napi eggs: To date, there are no detailed studies on plant responses of different oilseed rape genotypes towards egg deposition by $C$. napi. In stems of the resynthesized line S30, following egg-deposition the severity of pith tissue degeneration was significantly reduced compared to the resynthesized line H30. On the contrary, in the cultivar Sollux which contained the highest number of eggs the severity of pith degeneration did not significantly differ from the other tested genotypes. Since the number of eggs varied widely between genotypes, the pith degeneration was related to one deposited egg. When correlated for this number no significant differences between the genotypes were found. There was no evidence for the type of response mounted by oilseed rape in defense against infestation by $C$. pallidactylus, where neoplasma formation in petioles 
following oviposition by C. pallidactylus may lead to increased mortality of egg batches (Nuss 2004), nor of a hypersensitive reaction, another defense response to egg deposition (Hilker et al. 2002). In addition, plant responses to egg deposition can affect the volatile bouquet emitted by the plants, thereby indirectly attracting egg parasitoids (Hilker et al. 2002).

Glucosinolates in C. napi infested stems: Glucosinolates have been shown to affect performance of crucifer-feeding insects (Mayer 2004; Schoonhoven et al. 2005). The glucosinolate content of brassicaceous plants may change in response to herbivory (Bodnaryk 1992; Bartlet et al. 1999). In stems infested by C. napi larvae, the glucosinolate profiles had changed considerably from their pre-infestation level, including marked falls in concentration. There were significant differences between genotypes, the profile of the resynthesized line S3 being distinct from the other tested genotypes. Bodnaryk (1992) and Bartlet et al. (1999) found, that changes due to both plant development and herbivory might be expected when comparing pre- and post-infestation glucosinolate levels of oilseed rape. In the present study, however, there was no evidence that the changes observed were associated with the infestation or performance of larvae as measured by the larval instar index and larval dry body masses of the $3^{\text {rd }}$ larval instar (open field, chapter III). In contrast, Ulmer and Dosdall (2006) detected that high levels of specific glucosinolates were associated with a reduced larval weight of $C$. obstrictus. This suggests that the prolonged development of $C$. napi larvae in the resynthesized line S30 is not related to the glucosinolates studied here.

\section{Conclusion}

This study has successfully demonstrated the potential of resynthesized lines of $B$. napus as potential sources of resistance against the stem-mining pest $C$. napi. High antixenosis resistance to $C$. napi in the resynthesized line S30 has been identified for the first time. In addition, in S30 a low level of C. pallidactylus infestation was found. The larval development of $C$. napi in S30 was delayed, thereby indicating antibiosis resistance to C. napi in this genotype.

The resistance of S30 to C. napi appears to be largely antixenotic. S30 being less acceptable to ovipositing females due to the combination of a long stem and a paucity of five specific glucosinolates, while the glucosinolates were not closely associated with the infestation level and performance of $C$. napi larvae. The resynthesized line S30 can provide a potential genetic source for breeding oilseed rape cultivars with resistance to $C$. napi. Resistant cultivars could provide an important element in integrated pest management systems 
Chapter V

(Gullan and Cranston 2005) in order to reduce insecticide applications. By reducing insecticide applications, beneficial organisms such as parasitoids can be enhanced. These parasitoids can help to reduce the pest population density on long term by parasitizing the pest larvae (Ulber et al. 2010).

Future work should focus on the identification of the factors determining the host location and acceptance by $C$. napi. To identify these factors the selected genotypes with contrasting levels of infestation by $C$. napi, need to by analyzed on further plant traits such as sugars, phenolics, volatile isothiocyanates or mechanical strength of the stem tissue. Further, DH-populations based on crosses of S30 with present cultivars might be used for further screenings on resistance to $C$. napi, resulting in the development of new cultivars with resistance to $C$. napi. 


\section{References}

Alford DV, Nilsson C, Ulber B (2003) Insect pests of oilseed rape crops. In: DV Alford (Eds.), Biocontrol of oilseed rape pests. Blackwell Science Ltd., Oxford, pp 9-42.

Ali JG, Agrawal AA (2012) Specialist versus generalist insect herbivores and plant defense. Trends in Plant Science 17:293-302.

Ballanger Y (1987) Nuisibilité du charancon de la tige du colza (Ceutorrhynchus napi Gyll.). Phytoma 384:35-37.

Bartlet E, Kiddle G, Williams I, Wallsgrove R (1999) Wound-induced increases in the glucosinolate content of oilseed rape and their effect on subsequent herbivory by a crucifer specialist. Entomologia Experimentalis et Applicata 91:163-167.

Bartlet E, Parsons D, Williams IH, Clark SJ (1994) The influence of glucosinolates and sugars on feeding by the cabbage stem flea beetle, Psylliodes chrysocephala. Entomologia Experimentalis et Applicata 73:77-83.

Blake A, Dosdall L, Keddie B (2010) Plant nutrients and the spatiotemporal distribution dynamics of Ceutorhynchus obstrictus (Coleoptera: Curculionidae) and its parasitoids. Environmental Entomology 39:1195-1205.

Bodnaryk RP (1992) Effects of wounding on glucosinolates in the cotyledons of oilseed rape and mustard. Phytochemistry 31:2671-2677.

Buechi R (1996) Eiablage des Rapsstengelruesslers Ceutorhynchus napi Gyll., in Abhaengigkeit der Stengellaenge bei verschiedenen Rapssorten. Anzeiger fuer Schaedlingskunde, Pflanzenschutz, Umweltschutz 69:136-139.

Chen Y-Z, Lin L, Wang C-W, Yeh C-C, Hwang S-Y (2004) Response of two Pieris (Lepidoptera: Pieridae) species to fertilization of a host plant. Zoological Studies 43:778-786.

Chew F, Renwick J (1995) Host plant choice in Pieris butterflies. In: RT Carde and WJ Bell (Eds.), Chemical Ecology of Insects 2. Chapman and Hall, New York, Victoria, Scarborough, Col. Polanco, pp 214-238.

Cleemput S, Becker HC (2012) Genetic variation in leaf and stem glucosinolates in resynthesized lines of winter rapeseed (Brassica napus L.). Genetic Resources and Crop Evolution 59:539-546.

Dechert G, Ulber B (2004) Interactions between the stem-mining weevils Ceutorhynchus napi Gyll. and Ceutorhynchus pallidactylus (Marsh.) (Coleoptera: Curculionidae) in oilseed rape. Agricultural and Forest Entomology 6:193-198. 
Derron J, Le Clech E, Bezençon N, Goy G (2004) Résistance des méligèthes du colza aux pyréthrinoïdes dans le bassin lémanique. Revue Suisse d'Agriculture 36:237-242.

Diedrichsen E, Sacristan M (1991) Resynthesis of amphidiploid Brassica species and their clubroot disease reaction. Proc Rapeseed Cong, Saskatoon, Canada, 9-11 July 1991, 1: 274-279.

Eickermann M (2011) Resynthesized lines and cultivars of Brassica napus L. provide sources of resistance to the cabbage stem weevil (Ceutorhynchus pallidactylus (Mrsh.)). Bulletin of Entomological Research 101:287-294.

Feeny P (1977) Defensive ecology of the cruciferae. Annals of the Missouri Botanical Garden 64:221-234.

Fenwick G, Heaney R (1983) Glucosinolates and their breakdown products in cruciferous crops, foods and feedingstuffs. Food Chemistry 11:249-271.

Friedt W (2011) Ausgangsmaterial. In: O Christen und W Friedt (Eds.), Winterraps, das Handbuch fuer Profis. DLG, Frankfurt am Main, pp 20-25.

Giamoustaris A, Mithen R (1995) The effect of modifying the glucosinolate content of leaves of oilseed rape (Brassica napus ssp. oleifera) on its interaction with specialist and generalist pests. Annals of Applied Biology 126:347-363.

Girke A, Schierholt A, Becker HC (2012). Extending the rapeseed genepool with resynthesized Brassica napus L. I: genetic diversity. Genetic Resources and Crop Evolution 59: 1441-1447.

Gullan PJ, Cranston PS (2005) The insects - an outline of entomology. Blackwell, Malden, Oxford, Victoria.

Hansen LM (2003) Insecticide-resistant pollen beetles (Meligethes aeneus F.) found in danish oilseed rape (Brassica napus L.) fields. Pest Management Science 59:1057-1059.

Heimbach U, Mueller A (2013) Incidence of pyrethroid-resistant oilseed rape pests in Germany. Pest Management Science 69:209-216.

Henning K (2013) Plant science meets food science: genetic effects of glucosinolate degregation under food processing in Brassica. Dissertation, University of Wageningen, Wageningen.

Hilker M, Rohfritsch O, Meiners T (2002) The plant's response towards insect egg deposition. In M Hilker and T Meiners (Eds.), Chemoecology of insect eggs and egg deposition. Blackwell, Berlin, Vienna, pp 205-233.

Hopkins RJ, van Dam NM, van Loon JJA (2009) Role of glucosinolates in insect-plant relationships and multitrophic interactions. Annual Review of Entomology 54:57-83. 
Huang X, Renwick J (1994) Relative activities of glucosinolates as oviposition stimulants for Pieris rapae and P. napi oleracea. Journal of Chemical Ecology 20:1025-1037.

Lerin J (1993) Influence of the growth rate of oilseed rape on the splitting of the stem after an attack of Ceutorhynchus napi Gyll. IOBC WPRS BULLETIN 16 (9):160-163.

Mayer AM (2004) Resistance to herbivores and fungal pathogens: variations on a common theme? A review comparing the effect of secondary metabolites, induced and constitutive, on herbivores and fungal pathogens. Israel Journal of Plant Sciences 52:279-292.

Mithen R (1992) Leaf glucosinolate profiles and their relationship to pest and disease resistance in oilseed rape. Euphytica 63:71-83.

Mithen R (2001) Glucosinolates-biochemistry, genetics and biological activity. Plant Growth Regulation 34:91-103.

Mrowczynski M (1998) Studies on pest damage of cultivars and lines of winter oilseed rape. IOBC WPRS BULLETIN 21 (5):153-154.

Nuss H (2004) Einfluss der Pflanzedichte und -architektur auf Abundanz und innnerpflanzliche Verteilung staengelminierender Schadinsekten in Winterraps. Dissertation, Georg-August Universitaet, Goettingen.

Olsson G, Ellerstrom S, Tsunoda S, Hinata K, Gomez-Campo C (1980) Polyploidy breeding in Europe. In: S Tsunoda, K Hinata and C Gomez-Canpo (Eds.), Brassica crops and wild allies. Scientific Society Press, Tokyo, pp 167-190.

Renwick JAA (2002) The chemical world of crucivores: lures, treats and traps. Entomologia Experimentalis et Applicata 104:35-42.

Renwick JAA, Radke CD, Sachdev-Gupta K, Staedler E (1992) Leaf surface chemicals stimulating oviposition by Pieris rapae (Lepidoptera: Pieridae) on cabbage. Chemoecology 3:33-38.

Roessingh P, Staedler E, Fenwick GR, Lewis JA, Nielsen JK, Hurter J, Ramp T (1992) Oviposition and tarsal chemoreceptors of the cabbage root fly are stimulated by glucosinolates and host plant extracts. Entomologia Experimentalis et Applicata 65:267-282.

Rygulla W, Snowdon R, Eynck C, Koopmann B, von Tiedemann A, Luehs W, Friedt W (2007) Broadening the genetic basis of Verticillium longisporum resistance in Brassica napus by interspecific hybridization. Phytopathology 97:1391-1396.

Sarfraz M, Dosdall L, Keddie B (2006) Diamond-back moth - host plant interactions: implications for pest management. Crop Protection 25:625-639. 
Schoonhoven LM, van Loon JJA, Dicke M (2005) Insect-plant biology. Oxford University Press, Oxford.

Seyis F, Friedt W, Luehs W (2001) Resynthese-Raps (Brassica napus L.) als genetische Ressource fuer die Qualitaets-und Ertragszuechtung. Schriften zu Genetischen Ressourcen 16:91-112.

Siemens DH, Mitchelolds T (1996) Glucosinolates and herbivory by specialists (Coleoptera: Chrysomelidae, Lepidoptera: Plutellidae): consequences of concentration and induced resistance. Environmental Entomology 25:1344-1353.

Tansey JA, Dosdall LM (2011) Differential responses by some insect pests to novel insectresistant Brassica napus L.. Proc Intern Rapeseed Cong, Prague, Czech Republic, 5-9 July 2011, CD-ROM.

Thieme T, Heimbach U, Mueller A (2010) Chemical control of insect pests and insecticide resistance in oilseed rape. In: IH Williams (Eds.), Biocontrol-based integrated management of oilseed rape pests. Springer Science and Business Media B.V., Dordrecht, Heidelberg, London, New York, pp 313-336.

Ulber B, Klukowski Z, Williams IH (2010) Impact of insecticides on parasitoids of oilseed rape pests. In: IH Williams (Eds.), Biocontrol-based integrated pest management of oilseed rape pests. Springer Science and Business Media B.V., Dordrecht, Heidelberg, London, New York, pp 337-356.

Ulmer BJ, Dosdall LM (2006) Glucosinolate profile and oviposition behavior in relation to the susceptibilities of Brassicaceae to the cabbage seedpod weevil. Entomologia Experimentalis et Applicata 121:203-213.

Van Loon JJA, Blaakmeer A, Griepink FC, van Beek TA, Schoonhoven LM, de Groot A (1992) Leaf surface compound from Brassica oleracea (Cruciferae) induces oviposition by Pieris brassicae (Lepidoptera: Pieridae). Chemoecology 3:39-44.

Williams IH (2010) The major insect pests of oilseed rape in Europe and their management: an overview. In: IH Williams (Eds.), Biocontrol-based integrated management of oilseed rape pests. Springer Science and Business Media B.V., Dordrecht, Heidelberg, London, New York, pp 1-43.

Zimmer CT, Koehler H, Nauen R (2014) Baseline susceptibility and insecticide resistance monitoring in European populations of Meligethes aeneus and Ceutorhynchus assimilis collected in winter oilseed rape. Entomologia Experimentalis et Applicata 150:279-288. 
Chapter V

Zimmer CT, Nauen R (2011) Pyrethroid resistance and thiacloprid baseline susceptibility of European populations of Meligethes aeneus (Coleoptera: Nitidulidae) collected in winter oilseed rape. Pest Management Science 67:599-608. 
Appendix

\section{Appendix}

Laboratory feeding experiment:

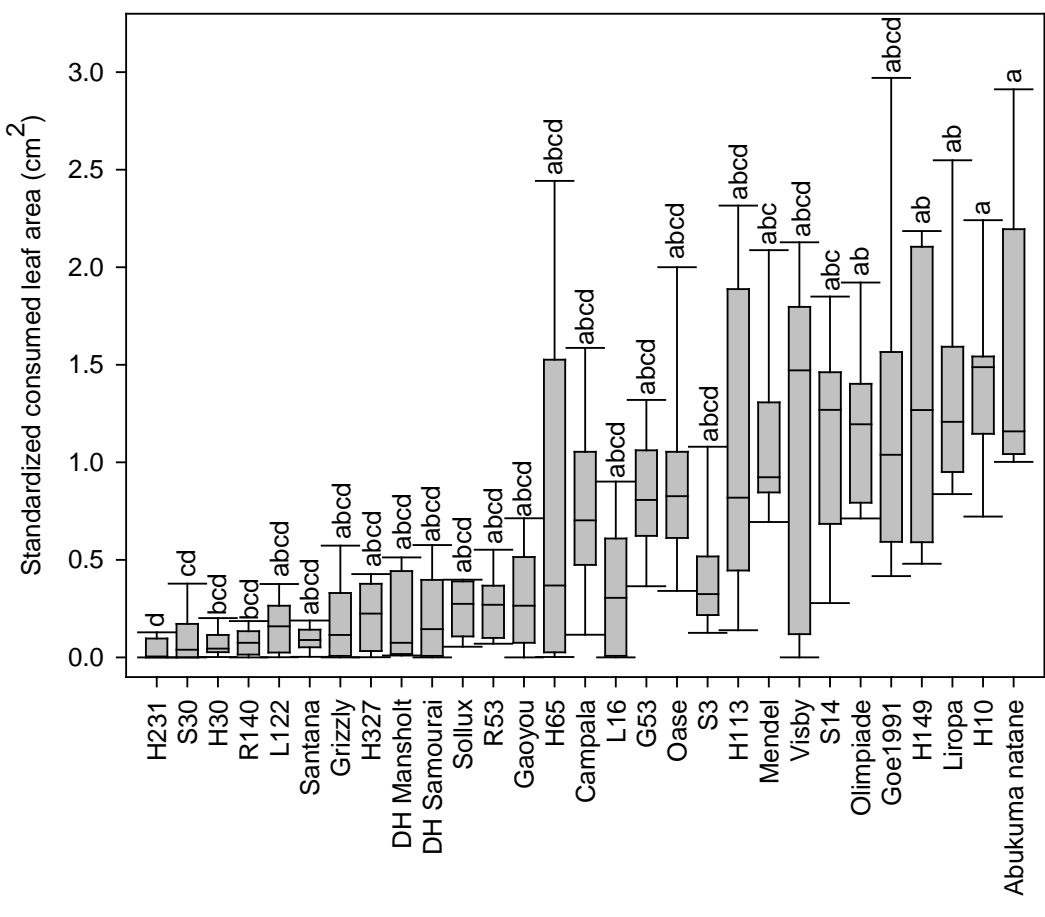

Genotype

Fig. 1 Standardized leaf area $\left(\mathrm{cm}^{2}\right)$ consumed by one male and female of Ceutorhynchus napi during 48 hours on $5^{\text {th }}$ oldest true leaf. No-choice laboratory experiment. The boxes encode the median and the interquartile range $\left(25^{\text {th }}-75^{\text {th }}\right.$ percentiles) of ten replicated plants. Genotypes with different letters differ significantly from each other according to Kruskal-Wallis Test, $P \leq 0.05$

There were no relationships between the consumed leaf areas by C. napi weevils and contents of individual glucosinolates, glucosinolate groups and the ratio between aliphatic and indolyl glucosinolates of control leaves (no feeding) and infested leaves (with feeding) (Linear Regression, $P \geq 0.05$ ) (Fig. 1 , Table 1 and Table 2). 
Appendix

Table 1 Mean glucosinolate contents ( $\mu \mathrm{mol} / \mathrm{g}$ D.W.) of $5^{\text {th }}$ oldest true leaf of control plants in no-choice laboratory experiment. PRO $=$ progoitrin, GNL $=$ napoleiferin, ALY $=$ glucoalyssin, GNA = gluconapin, GBN = glucobrassicanapin, RAA $=$ glucoraphanin; $4 \mathrm{OH}=4$-hydroxyglucobrassicin, $\mathrm{GBC}=$ glucobrassicin, $4 \mathrm{ME}=4$-methoxyglucobrassicin, $\mathrm{NEO}=$ neoglucobrassicin, NAS = gluconasturtiin

\begin{tabular}{|c|c|c|c|c|c|c|c|c|c|c|c|c|c|c|c|}
\hline Genotype & PRO & RAA & GNL & ALY & GNA & $4 \mathrm{OH}$ & GBN & GBC & NAS & $4 \mathrm{ME}$ & NEO & Aliphatic & Indolyl & $\mathrm{A} / \mathrm{I}$ & Total \\
\hline G53 & 2.39 & 0.48 & 0.00 & 0.51 & 2.08 & 0.00 & 3.05 & 0.50 & 0.00 & 0.07 & 0.00 & 8.51 & 0.58 & 14.72 & 9.09 \\
\hline Mendel & 1.85 & 0.00 & 0.16 & 0.56 & 1.10 & 0.00 & 2.07 & 0.29 & 0.24 & 0.08 & 0.03 & 5.73 & 0.40 & 14.18 & 6.38 \\
\hline Goe1991 & 2.41 & 0.00 & 0.11 & 1.28 & 0.34 & 0.00 & 1.37 & 0.66 & 0.00 & 0.12 & 0.00 & 5.52 & 0.78 & 7.09 & 6.30 \\
\hline Liropa & 0.37 & 0.00 & 0.12 & 0.00 & 0.00 & 0.00 & 0.18 & 0.34 & 0.00 & 0.07 & 0.10 & 0.66 & 0.51 & 1.29 & 1.18 \\
\hline S14 & 3.65 & 0.00 & 0.00 & 1.93 & 0.57 & 0.00 & 5.20 & 0.75 & 0.00 & 0.06 & 0.10 & 11.35 & 0.90 & 12.58 & 12.26 \\
\hline Visby & 1.50 & 0.00 & 0.00 & 0.42 & 0.63 & 0.13 & 0.79 & 0.19 & 0.00 & 0.00 & 0.00 & 3.34 & 0.32 & 10.38 & 3.66 \\
\hline H113 & 12.85 & 0.00 & 0.00 & 3.71 & 5.49 & 0.00 & 6.55 & 0.33 & 1.25 & 0.00 & 0.00 & 28.60 & 0.33 & 86.85 & 30.18 \\
\hline Campala & 0.87 & 0.00 & 0.00 & 0.40 & 0.63 & 0.00 & 0.63 & 0.00 & 0.00 & 0.00 & 0.00 & 2.52 & 0.00 & 0.00 & 2.52 \\
\hline H149 & 0.81 & 0.00 & 0.00 & 0.26 & 2.15 & 0.00 & 0.98 & 0.21 & 0.00 & 0.00 & 0.00 & 4.19 & 0.21 & 19.84 & 4.41 \\
\hline S30 & 1.63 & 0.00 & 0.00 & 0.96 & 0.66 & 0.11 & 2.42 & 0.22 & 0.19 & 0.08 & 0.07 & 5.68 & 0.48 & 11.85 & 6.34 \\
\hline DH Samourai & 0.23 & 0.00 & 0.07 & 0.08 & 0.10 & 0.09 & 0.00 & 0.26 & 0.00 & 0.06 & 0.00 & 0.47 & 0.41 & 1.15 & 0.88 \\
\hline Grizzly & 1.69 & 0.00 & 0.00 & 0.78 & 1.22 & 0.04 & 2.26 & 0.27 & 0.16 & 0.04 & 0.04 & 5.93 & 0.39 & 15.25 & 6.48 \\
\hline H65 & 1.81 & 0.17 & 0.13 & 1.18 & 1.18 & 0.18 & 1.60 & 0.76 & 0.72 & 0.10 & 0.05 & 6.07 & 1.10 & 5.52 & 7.90 \\
\hline DH Mansholt & 5.28 & 0.12 & 0.00 & 1.34 & 1.08 & 0.08 & 1.91 & 0.26 & 0.24 & 0.00 & 0.06 & 9.72 & 0.39 & 24.62 & 10.36 \\
\hline Н 327 & 9.32 & 0.00 & 0.00 & 3.02 & 3.24 & 0.06 & 5.11 & 0.38 & 0.27 & 0.20 & 0.12 & 20.69 & 0.77 & 26.97 & 21.74 \\
\hline L 122 & 9.53 & 0.25 & 0.00 & 3.54 & 3.09 & 0.17 & 7.22 & 0.22 & 0.25 & 0.07 & 0.05 & 23.62 & 0.51 & 46.74 & 24.38 \\
\hline Н 10 & 6.47 & 0.55 & 0.00 & 1.75 & 2.95 & 0.09 & 1.57 & 0.20 & 0.49 & 0.02 & 0.05 & 13.30 & 0.36 & 37.43 & 14.14 \\
\hline Olimpiade & 8.95 & 0.31 & 0.00 & 2.74 & 5.76 & 0.10 & 2.83 & 0.40 & 0.34 & 0.05 & 0.00 & 20.58 & 0.55 & 37.55 & 21.48 \\
\hline Abukuma natane & 10.35 & 0.00 & 0.00 & 2.91 & 3.70 & 0.06 & 4.82 & 0.25 & 0.70 & 0.10 & 0.16 & 21.78 & 0.56 & 38.71 & 23.04 \\
\hline H231 & 9.41 & 1.62 & 0.00 & 3.88 & 1.37 & 0.10 & 4.96 & 1.55 & 0.26 & 0.07 & 0.25 & 21.24 & 1.96 & 10.82 & 23.46 \\
\hline H30 & 2.90 & 0.83 & 0.14 & 3.48 & 0.12 & 0.04 & 0.48 & 0.31 & 0.17 & 0.02 & 0.06 & 7.94 & 0.43 & 18.51 & 8.55 \\
\hline R140 & 1.69 & 0.40 & 0.00 & 0.73 & 0.20 & 0.03 & 1.25 & 1.70 & 0.21 & 0.04 & 0.00 & 4.28 & 1.77 & 2.42 & 6.27 \\
\hline Santana & 0.18 & 0.00 & 0.00 & 0.10 & 0.00 & 0.00 & 0.09 & 0.96 & 0.00 & 0.05 & 0.07 & 0.37 & 1.08 & 0.35 & 1.45 \\
\hline S3 & 4.82 & 0.17 & 0.16 & 0.23 & 4.52 & 0.05 & 1.25 & 0.21 & 0.00 & 0.14 & 0.00 & 11.15 & 0.40 & 27.88 & 11.55 \\
\hline Gaoyou & 0.54 & 0.17 & 0.00 & 0.00 & 0.13 & 0.04 & 0.04 & 0.05 & 0.00 & 0.03 & 0.00 & 0.88 & 0.12 & 7.33 & 1.00 \\
\hline Sollux & 4.08 & 0.14 & 0.13 & 0.55 & 2.73 & 0.07 & 0.75 & 0.07 & 0.00 & 0.10 & 0.00 & 8.38 & 0.24 & 34.92 & 8.62 \\
\hline R53 & 0.24 & 0.25 & 0.00 & 0.00 & 0.97 & 0.10 & 0.37 & 0.12 & 0.00 & 0.03 & 0.00 & 1.83 & 0.25 & 7.32 & 2.08 \\
\hline L16 & 0.35 & 0.21 & 0.00 & 0.16 & 0.13 & 0.05 & 0.26 & 0.06 & 0.00 & 0.00 & 0.00 & 1.11 & 0.11 & 10.09 & 1.22 \\
\hline
\end{tabular}


Appendix

Table 2 Mean glucosinolate contents $\left(\mu \mathrm{mol} / \mathrm{g}\right.$ D.W.) of $5^{\text {th }}$ oldest true leaf of infested plants in no-choice laboratory experiment. PRO $=$ progoitrin, GNL $=$ napoleiferin, ALY $=$ glucoalyssin, GNA = gluconapin, GBN = glucobrassicanapin, RAA $=$ glucoraphanin; 4OH $=4$-hydroxyglucobrassicin, $\mathrm{GBC}=$ glucobrassicin, $4 \mathrm{ME}=4$-methoxyglucobrassicin, $\mathrm{NEO}=$ neoglucobrassicin, NAS = gluconasturtiin

\begin{tabular}{|c|c|c|c|c|c|c|c|c|c|c|c|c|c|c|c|}
\hline Genotype & PRO & RAA & GNL & ALY & GNA & $4 \mathrm{OH}$ & GBN & GBC & NAS & $4 \mathrm{ME}$ & NEO & Aliphatic & Indolyl & $\mathrm{A} / \mathrm{I}$ & Total \\
\hline G53 & 3.73 & 0.96 & 0.00 & 0.58 & 3.97 & 0.00 & 4.24 & 1.31 & 0.06 & 0.03 & 0.01 & 13.48 & 1.36 & 9.93 & 14.89 \\
\hline Mendel & 1.96 & 0.00 & 0.00 & 0.39 & 1.38 & 0.00 & 1.89 & 0.83 & 0.00 & 0.02 & 0.30 & 5.61 & 1.14 & 4.91 & 6.75 \\
\hline Goe1991 & 2.75 & 0.00 & 0.00 & 1.58 & 0.38 & 0.00 & 1.02 & 1.52 & 0.00 & 0.05 & 0.73 & 5.72 & 2.31 & 2.48 & 8.03 \\
\hline Liropa & 0.47 & 0.00 & 0.03 & 0.08 & 0.00 & 0.00 & 0.29 & 0.60 & 0.00 & 0.03 & 0.46 & 0.88 & 1.09 & 0.81 & 1.97 \\
\hline S14 & 9.52 & 0.10 & 0.00 & 5.14 & 2.16 & 0.00 & 9.93 & 1.38 & 0.28 & 0.07 & 0.75 & 26.85 & 2.20 & 12.19 & 29.34 \\
\hline Visby & 1.56 & 0.00 & 0.00 & 0.48 & 1.20 & 0.06 & 0.63 & 0.23 & 0.00 & 0.00 & 0.00 & 3.88 & 0.29 & 13.26 & 4.17 \\
\hline Oase & 0.85 & 0.00 & 0.00 & 0.43 & 0.11 & 0.00 & 0.36 & 1.01 & 0.00 & 0.00 & 0.03 & 1.75 & 1.04 & 1.68 & 2.80 \\
\hline H113 & 2.82 & 0.00 & 0.00 & 0.96 & 1.81 & 0.05 & 2.14 & 0.70 & 0.00 & 0.00 & 0.21 & 7.73 & 0.96 & 8.05 & 8.69 \\
\hline Campala & 2.82 & 0.00 & 0.00 & 0.96 & 1.81 & 0.05 & 2.14 & 0.70 & 0.00 & 0.00 & 0.21 & 7.73 & 0.96 & 8.05 & 8.69 \\
\hline H149 & 4.21 & 0.00 & 0.00 & 0.80 & 3.54 & 0.00 & 3.08 & 0.62 & 0.00 & 0.00 & 0.08 & 11.63 & 0.70 & 16.65 & 12.33 \\
\hline S30 & 0.71 & 0.00 & 0.00 & 0.39 & 0.36 & 0.00 & 0.78 & 0.13 & 0.00 & 0.02 & 0.04 & 2.24 & 0.20 & 11.51 & 2.44 \\
\hline DH Samourai & 0.16 & 0.00 & 0.00 & 0.00 & 0.00 & 0.02 & 0.00 & 0.36 & 0.00 & 0.06 & 0.03 & 0.16 & 0.46 & 0.34 & 0.62 \\
\hline Grizzly & 2.11 & 0.00 & 0.05 & 1.41 & 2.18 & 0.03 & 3.89 & 0.57 & 0.27 & 0.05 & 0.05 & 9.63 & 0.71 & 13.63 & 10.61 \\
\hline H65 & 0.97 & 0.00 & 0.00 & 0.66 & 0.67 & 0.08 & 0.72 & 0.44 & 0.35 & 0.08 & 0.05 & 3.02 & 0.65 & 4.66 & 4.02 \\
\hline DH Mansholt & 4.98 & 0.00 & 0.00 & 0.52 & 1.03 & 0.05 & 1.46 & 0.20 & 0.26 & 0.00 & 0.05 & 7.99 & 0.29 & 27.10 & 8.55 \\
\hline H327 & 6.56 & 0.00 & 0.00 & 1.82 & 2.95 & 0.00 & 3.56 & 0.15 & 0.31 & 0.11 & 0.07 & 14.90 & 0.33 & 45.66 & 15.53 \\
\hline L122 & 8.82 & 0.32 & 0.00 & 4.33 & 2.18 & 0.13 & 4.78 & 0.34 & 0.28 & 0.09 & 0.15 & 20.44 & 0.72 & 28.40 & 21.43 \\
\hline H10 & 4.06 & 0.29 & 0.00 & 1.19 & 2.17 & 0.14 & 1.02 & 0.63 & 0.34 & 0.05 & 0.56 & 8.73 & 1.38 & 6.33 & 10.46 \\
\hline Olimpiade & 3.29 & 0.00 & 0.00 & 0.56 & 2.74 & 0.03 & 0.94 & 0.28 & 0.19 & 0.04 & 0.09 & 7.52 & 0.43 & 17.51 & 8.14 \\
\hline Abukuma natane & 2.27 & 0.00 & 0.00 & 0.28 & 1.00 & 0.00 & 0.68 & 0.07 & 0.16 & 0.11 & 0.12 & 4.23 & 0.30 & 14.32 & 4.68 \\
\hline H231 & 2.95 & 0.46 & 0.00 & 1.69 & 0.16 & 0.04 & 1.29 & 1.17 & 0.03 & 0.01 & 0.18 & 6.55 & 1.40 & 4.69 & 7.98 \\
\hline H30 & 1.90 & 0.13 & 0.07 & 1.99 & 0.04 & 0.03 & 0.88 & 1.14 & 0.11 & 0.04 & 0.14 & 5.02 & 1.35 & 3.73 & 6.48 \\
\hline R140 & 2.80 & 0.54 & 0.00 & 1.36 & 0.44 & 0.00 & 2.64 & 1.09 & 0.19 & 0.03 & 0.00 & 7.77 & 1.13 & 6.90 & 9.08 \\
\hline Santana & 0.50 & 0.00 & 0.00 & 0.29 & 0.17 & 0.04 & 0.58 & 1.82 & 0.03 & 0.05 & 0.12 & 1.54 & 2.03 & 0.76 & 3.60 \\
\hline S3 & 22.14 & 0.14 & 0.57 & 2.11 & 12.70 & 0.09 & 5.08 & 0.37 & 0.00 & 0.17 & 0.00 & 42.74 & 0.63 & 67.84 & 43.37 \\
\hline Gaoyou & 9.83 & 0.00 & 0.00 & 4.34 & 3.16 & 0.41 & 7.14 & 0.68 & 0.00 & 0.21 & 0.00 & 24.47 & 1.30 & 18.82 & 25.77 \\
\hline Sollux & 22.30 & 0.12 & 1.20 & 12.23 & 5.33 & 0.33 & 4.35 & 0.40 & 0.00 & 0.16 & 0.00 & 45.53 & 0.89 & 51.16 & 46.42 \\
\hline R53 & 2.66 & 0.17 & 0.00 & 0.91 & 2.59 & 0.31 & 2.43 & 1.01 & 0.00 & 0.05 & 0.00 & 8.76 & 1.37 & 6.39 & 10.13 \\
\hline L16 & 2.32 & 0.18 & 0.00 & 0.68 & 0.49 & 0.22 & 2.19 & 0.49 & 0.00 & 0.00 & 0.00 & 5.86 & 0.71 & 8.25 & 6.57 \\
\hline
\end{tabular}


Appendix

Table 3 Field experiments in 2010/2011, 2011/2012 and 2012/2013 at different locations. Larval infestation by Ceutorhynchus napi per main stem of 30 Brassica napus genotypes. Mean values $\left( \pm\right.$ SE) of ten plants and two replicates. KW-ANOVA, $P \leq 0.05$; Marienstein May $5^{\text {th }} 2011(H(27, N=56)=28.240, P=0.398)$, Einbeck May $5^{\text {th }} 2011(H(29, N=60)=20.209, P=$ 0.886), Göttingen-Reinshof May $3^{\text {rd }} 2012(H(11, N=24)=18.755, P=0.066)$, Einbeck May $9^{\text {th }} 2012\left(H(21(N=44)=30.131, P=0.089)\right.$, Peine May $10^{\text {th }} 2012(H(14, N=30)=17.032, P$ $=0.255)$, Göttingen-Reinshof May $21^{\text {st }} 2013(H(25, N=52)=30.342, P=0.471)$, Peine May $23^{\text {rd }} 2013(H(21, N=44)=30.315, P=0.086)$, Semi-field experiment Göttingen May $16^{\text {th }} 2013$ $(H(11, N=60)=16.756, P=0.115)$

\begin{tabular}{|c|c|c|c|c|c|c|c|c|c|c|c|c|}
\hline Genotype & $\begin{array}{l}\text { Marienstein } \\
2011\end{array}$ & $\begin{array}{l}\text { Reinshof } \\
2011\end{array}$ & $\begin{array}{l}\text { Einbeck } \\
2011\end{array}$ & $\begin{array}{l}\text { Peine } \\
2011\end{array}$ & $\begin{array}{l}\text { Reinshof } \\
2012\end{array}$ & $\begin{array}{l}\text { Einbeck } \\
2012\end{array}$ & $\begin{array}{l}\text { Peine } \\
2012\end{array}$ & $\begin{array}{l}\text { Reinshof } \\
2013\end{array}$ & $\begin{array}{l}\text { Einbeck } \\
2013\end{array}$ & $\begin{array}{l}\text { Peine } \\
2013\end{array}$ & $\begin{array}{l}\text { Semi-field } \\
2013\end{array}$ & $\begin{array}{l}\text { Mean } \\
\text { value }\end{array}$ \\
\hline H231 & $0.13 \pm 0.13$ & - & $0.93 \pm 0.73$ & - & - & - & - & - & - & - & - & 0.53 \\
\hline Grizzly & $0.13 \pm 0.13$ & - & $0.87 \pm 0.80$ & - & $5.55 \pm 0.25$ & $0.20 \pm 0.10$ & $2.25 \pm 1.25$ & $0.50 \pm 0.10$ & - & $0.55 \pm 0.05$ & - & 1.44 \\
\hline S14 & $0.70 \pm 0.30$ & - & $0.73 \pm 0.60$ & - & $2.15 \pm 0.55$ & $0.10 \pm 0.10$ & $2.45 \pm 0.15$ & $0.45 \pm 0.35$ & - & $0.95 \pm 0.05$ & $1.02 \pm 0.33$ & 1.07 \\
\hline Express617 & $0.00 \pm 0.00$ & - & $0.60 \pm 0.40$ & - & $5.10 \pm 0.50$ & $0.35 \pm 0.15$ & $2.05 \pm 0.45$ & $0.15 \pm 0.05$ & - & $2.85 \pm 2.45$ & $0.14 \pm 0.09$ & 1.41 \\
\hline Liropa & $0.80 \pm 0.60$ & - & $1.13 \pm 1.00$ & - & - & $1.00 \quad 0.70$ & $1.35 \pm 0.75$ & $1.10 \pm 0.30$ & - & $1.25 \pm 0.05$ & $1.28 \pm 0.60$ & 1.13 \\
\hline Olimpiade & $0.83 \pm 0.57$ & - & $0.43 \pm 0.10$ & - & - & - & - & - & - & - & - & 0.63 \\
\hline Н327 & $0.38 \pm 0.15$ & - & $0.85 \pm 0.47$ & - & - & - & - & $0.00 \pm 0.00$ & - & $0.55 \pm 0.25$ & - & 0.45 \\
\hline R140 & $0.83 \pm 0.83$ & - & $0.13 \pm 0.13$ & - & - & - & - & $0.30 \pm 0.20$ & - & - & $0.40 \pm 0.20$ & 0.42 \\
\hline H65 & $0.53 \pm 0.33$ & - & $0.23 \pm 0.10$ & - & - & - & - & - & - & $0.65 \pm 0.15$ & - & 0.47 \\
\hline H10 & $0.00 \pm 0.00$ & - & $0.40 \pm 0.00$ & - & - & - & - & $1.30 \pm 0.80$ & - & - & - & 0.57 \\
\hline G53 & $0.50 \pm 0.17$ & - & $0.60 \pm 0.60$ & - & - & $0.35 \pm 0.35$ & - & $0.45 \pm 0.35$ & - & $3.20 \pm 1.10$ & - & 1.02 \\
\hline L122 & $0.63 \pm 0.03$ & - & $0.23 \pm 0.23$ & - & - & $0.20 \pm 0.10$ & - & $0.95 \pm 0.35$ & - & $0.92 \pm 0.65$ & - & 0.59 \\
\hline H113 & $0.00 \pm 0.00$ & - & $0.40 \pm 0.00$ & - & - & $0.20 \pm 0.20$ & - & $1.00 \pm 0.60$ & - & $1.85 \pm 0.15$ & - & 0.69 \\
\hline R53 & $0.17 \pm 0.17$ & - & $0.80 \pm 0.60$ & - & - & - & - & $1.45 \pm 1.25$ & - & $0.25 \pm 0.25$ & - & 0.67 \\
\hline L16 & $0.77 \pm 0.77$ & - & $0.37 \pm 0.30$ & - & $3.35 \pm 1.95$ & $0.00 \pm 0.00$ & $0.30 \pm 0.30$ & $0.50 \pm 0.10$ & - & $1.90 \pm 0.50$ & - & 1.03 \\
\hline Visby & $0.07 \pm 0.07$ & - & $0.40 \pm 0.07$ & - & $1.60 \pm 0.30$ & $1.55 \pm 0.05$ & $0.65 \pm 0.25$ & $1.00 \pm 0.10$ & - & - & $0.82 \pm 0.49$ & 0.87 \\
\hline Н30 & $0.37 \pm 0.37$ & - & $0.40 \pm 0.13$ & - & $0.40 \pm 0.85$ & $0.00 \pm 0.00$ & $1.00 \pm 0.20$ & $1.25 \pm 0.25$ & - & - & $0.86 \pm 0.19$ & 0.61 \\
\hline Mendel & $0.20 \pm 0.20$ & - & $0.43 \pm 0.30$ & - & $5.00 \pm 0.90$ & $1.00 \pm 0.20$ & $1.55 \pm 1.05$ & $0.85 \pm 0.25$ & - & $1.47 \pm 0.04$ & $0.86 \pm 0.38$ & 1.42 \\
\hline S3 & $0.53 \pm 0.13$ & - & $0.17 \pm 0.10$ & - & $5.10 \pm 0.10$ & $0.05 \pm 0.05$ & $1.00 \pm 0.40$ & $0.55 \pm 0.55$ & - & $1.05 \pm 0.65$ & - & 1.21 \\
\hline S30 & $0.57 \pm 0.43$ & - & $0.40 \pm 0.40$ & - & $0.75 \pm 0.25$ & $0.15 \pm 0.15$ & $1.75 \pm 1.35$ & $0.00 \pm 0.00$ & - & $0.00 \pm 0.00$ & $0.20 \pm 0.15$ & 0.48 \\
\hline Gaoyou & $0.00 \pm 0.00$ & - & $0.67 \pm 0.13$ & - & - & $0.00 \pm 0.00$ & - & $2.20 \pm 0.40$ & - & $1.75 \pm 0.65$ & $0.68 \pm 0.29$ & 0.88 \\
\hline Sollux & $0.47 \pm 0.40$ & - & $0.73 \pm 0.67$ & - & $2.45 \pm 0.85$ & $1.10 \pm 0.50$ & $2.65 \pm 0.55$ & $0.75 \pm 0.75$ & - & $1.80 \pm 0.40$ & $1.26 \pm 0.65$ & 1.40 \\
\hline H149 & $0.07 \pm 0.07$ & - & $0.93 \pm 0.00$ & - & - & $0.10 \pm 0.10$ & - & $0.35 \pm 0.15$ & - & - & - & 0.36 \\
\hline Abukuma natane & $0.80 \pm 0.47$ & - & $0.40 \pm 0.07$ & - & - & - & - & - & - & - & - & 0.60 \\
\hline Campala & $0.17 \pm 0.17$ & - & $0.13 \pm 0.07$ & - & $2.80 \pm 0.20$ & $0.05 \pm 0.05$ & $1.20 \pm 0.50$ & $0.30 \pm 0.00$ & - & $0.90 \pm 0.50$ & - & 0.79 \\
\hline Goe1991 & $0.00 \pm 0.00$ & - & $0.00 \pm 0.00$ & - & - & $0.00 \pm 0.00$ & $0.30 \pm 0.10$ & $1.50 \pm 0.40$ & - & $0.40 \pm 0.20$ & - & 0.37 \\
\hline Santana & $0.40 \pm 0.40$ & - & $0.23 \pm 0.10$ & - & - & $0.10 \pm 0.10$ & - & $0.45 \pm 0.25$ & - & $1.43 \pm 0.33$ & - & 0.52 \\
\hline DH Mansholt & $0.24 \pm 0.17$ & - & $0.97 \pm 0.63$ & - & $2.70 \pm 0.60$ & $0.15 \pm 0.15$ & $2.45 \pm 0.05$ & $0.60 \pm 0.20$ & - & $2.20 \pm 0.30$ & - & 1.33 \\
\hline Oase & - & - & $0.27 \pm 0.07$ & - & - & $0.25 \pm 0.05$ & $1.85 \pm 0.35$ & $0.30 \pm 0.30$ & - & $0.70 \pm 0.60$ & $0.68 \pm 0.28$ & 0.68 \\
\hline DH Samourai & - & - & - & - & - & $0.00 \pm 0.00$ & - & $1.15 \pm 0.55$ & - & $2.30 \pm 1.40$ & $0.12 \pm 0.08$ & 0.89 \\
\hline Mean value & 0.36 & - & 0.51 & - & 3.08 & 2.23 & - & 0.74 & - & 1.31 & 0.69 & \\
\hline
\end{tabular}


Appendix

Table 4 Field experiments in 2010/2011, 2011/2012 and 2012/2013 at different locations. Larval infestation by Ceutorhynchus pallidactylus per main stem of 30 Brassica napus genotypes. Mean values $( \pm \mathrm{SE})$ of ten plants and two replicates. KW-ANOVA, $P \leq 0.05$; Marienstein May $5^{\text {th }} 2011(H(27, N=56)=23.772, P=0.643)$, Einbeck May $5^{\text {th }} 2011(H(29, N=60)=35.752$, $P=0.181)$, Göttingen-Reinshof May $3^{\text {rd }} 2012(H(11, N=24)=14.126, P=0.226)$, Einbeck May $9^{\text {th }} 2012\left(H(21(N=44)=22.512, P=0.371)\right.$, Peine May $10^{\text {th }} 2012(H(14, N=30)=20.101$, $P=0.127)$, Göttingen-Reinshof May $21^{\text {st }} 2013(H(25, N=52)=24.852, P=0.471)$, Peine May $23^{\text {rd }} 2013(H(21, N=44)=21.861, P=0.408)$

\begin{tabular}{|c|c|c|c|c|c|c|c|c|c|c|c|}
\hline Genotype & $\begin{array}{l}\text { Marienstein } \\
2011\end{array}$ & $\begin{array}{l}\text { Reinshof } \\
2011\end{array}$ & $\begin{array}{l}\text { Einbeck } \\
2011\end{array}$ & $\begin{array}{l}\text { Peine } \\
2011\end{array}$ & $\begin{array}{l}\text { Reinshof } \\
2012\end{array}$ & $\begin{array}{l}\text { Einbeck } \\
2012 \\
\end{array}$ & $\begin{array}{l}\text { Peine } \\
2012\end{array}$ & $\begin{array}{l}\text { Reinshof } \\
2013\end{array}$ & $\begin{array}{l}\text { Einbeck } \\
2013 \\
\end{array}$ & $\begin{array}{l}\text { Peine } \\
2013\end{array}$ & $\begin{array}{l}\text { Mean } \\
\text { value }\end{array}$ \\
\hline H231 & $0.44 \pm 0.37$ & - & $0.60 \pm 0.27$ & - & - & - & - & - & - & - & 0.52 \\
\hline Grizzly & $0.40 \pm 0.07$ & - & $1.47 \pm 1.33$ & - & $0.30 \pm 0.00$ & $0.50 \pm 0.40$ & $0.95 \pm 0.05$ & $6.05 \pm 2.55$ & - & - & 1.60 \\
\hline S14 & $0.70 \pm 0.07$ & - & $0.90 \pm 0.23$ & - & $2.50 \pm 0.60$ & $0.35 \pm 0.35$ & $0.60 \pm 0.30$ & $0.60 \pm 0.60$ & - & $11.50 \pm 0.60$ & 2.27 \\
\hline Express617 & $0.74 \pm 0.74$ & - & $0.97 \pm 0.63$ & - & $2.95 \pm 0.35$ & $0.40 \pm 0.40$ & $0.95 \pm 0.55$ & $3.70 \pm 1.30$ & - & $12.70 \pm 3.70$ & 3.20 \\
\hline Liropa & $0.17 \pm 0.17$ & - & $2.07 \pm 0.87$ & - & - & $0.20 \pm 0.20$ & $0.20 \pm 0.20$ & $5.10 \pm 4.10$ & - & $16.10 \pm 6.10$ & 3.97 \\
\hline Olimpiade & $1.87 \pm 1.40$ & - & $1.47 \pm 0.93$ & - & - & - & - & - & - & - & 1.67 \\
\hline H327 & $0.07 \pm 0.07$ & - & $0.23 \pm 0.16$ & - & - & - & - & $3.20 \pm 0.60$ & - & $7.35 \pm 0.95$ & 2.71 \\
\hline R140 & $0.10 \pm 0.10$ & - & $0.27 \pm 0.13$ & - & - & - & - & $2.25 \pm 1.95$ & - & - & 0.87 \\
\hline H65 & $0.27 \pm 0.27$ & - & $0.10 \pm 0.10$ & - & - & - & - & - & - & - & 0.19 \\
\hline H10 & $0.07 \pm 0.07$ & - & $0.20 \pm 0.07$ & - & - & - & - & $1.20 \pm 0.90$ & - & - & 0.49 \\
\hline G53 & $0.80 \pm 0.73$ & - & $0.07 \pm 0.07$ & - & - & $0.00 \pm 0.00$ & - & $1.55 \pm 0.55$ & - & $19.60 \pm 9.00$ & 4.40 \\
\hline L122 & $0.50 \pm 0.50$ & - & $1.30 \pm 1.10$ & - & - & $1.00 \pm 0.10$ & - & $4.70 \pm 1.30$ & - & $7.85 \pm 0.95$ & 3.07 \\
\hline H113 & $0.37 \pm 0.24$ & - & $0.27 \pm 0.00$ & - & - & $0.1 \pm 0.05$ & - & $2.55 \pm 0.55$ & - & $9.90 \pm 2.50$ & 2.64 \\
\hline R53 & $0.40 \pm 0.13$ & - & $0.27 \pm 0.13$ & - & - & - & - & $0.90 \pm 0.50$ & - & $6.60 \pm 3.20$ & 2.04 \\
\hline L16 & $0.04 \pm 0.04$ & - & $0.17 \pm 0.10$ & - & $2.30 \pm 1.70$ & $0.45 \pm 0.45$ & $0.50 \pm 0.10$ & $3.65 \pm 3.15$ & - & $15.10 \pm 4.80$ & 3.17 \\
\hline Visby & $0.10 \pm 0.10$ & - & $0.27 \pm 0.20$ & - & $2.35 \pm 1.45$ & $0.05 \pm 0.05$ & $0.55 \pm 0.05$ & $3.85 \pm 2.25$ & - & $9.60 \pm 1.40$ & 2.40 \\
\hline H30 & $0.04 \pm 0.04$ & - & $0.00 \pm 0.00$ & - & $0.50 \pm 0.20$ & $0.00 \pm 0.00$ & $1.00 \pm 0.20$ & $2.90 \pm 2.00$ & - & - & 0.74 \\
\hline Mendel & $0.64 \pm 0.64$ & - & $0.53 \pm 0.53$ & - & $1.45 \pm 0.05$ & $0.15 \pm 0.15$ & $2.00 \pm 0.10$ & $5.05 \pm 4.35$ & - & $11.50 \pm 0.50$ & 3.05 \\
\hline S3 & $1.67 \pm 0.27$ & - & $0.07 \pm 0.00$ & - & $2.65 \pm 1.65$ & $0.00 \pm 0.00$ & $1.00 \pm 0.70$ & $3.10 \pm 0.40$ & - & $14.30 \pm 3.50$ & 3.26 \\
\hline S30 & $0.44 \pm 0.04$ & - & $0.37 \pm 0.37$ & - & $1.55 \pm 1.05$ & $0.20 \pm 0,20$ & $0.90 \pm 0.40$ & $1.00 \pm 0.40$ & - & $7.95 \pm 2.15$ & 1.77 \\
\hline Gaoyou & $0.33 \pm 0.20$ & - & $0.03 \pm 0.30$ & - & - & $0.95 \pm 0.55$ & - & $1.85 \pm 0.15$ & - & $11.55 \pm 3.05$ & 2.94 \\
\hline Sollux & $0.10 \pm 0.10$ & - & $0.10 \pm 010$ & - & $1.95 \pm 0.05$ & $0.75 \pm 0.45$ & $4.20 \pm 1.00$ & $3.85 \pm 3.65$ & - & $13.25 \pm 0.25$ & 3.46 \\
\hline H149 & $0.04 \pm 0.04$ & - & $0.93 \pm 0.00$ & - & - & $0.35 \pm 0.35$ & - & $1.85 \pm 0.05$ & - & - & 0.79 \\
\hline Abukuma natane & $0.34 \pm 0.34$ & - & $0.00 \pm 0.00$ & - & - & - & - & - & - & - & 0.17 \\
\hline Campala & $0.30 \pm 0.30$ & - & $0.07 \pm 0.07$ & - & $0.50 \pm 0.20$ & $0.10 \pm 0.10$ & $0.05 \pm 0.05$ & $5.25 \pm 0.15$ & - & $14.95 \pm 12.25$ & 3.03 \\
\hline Goe1991 & $0.00 \pm 0.00$ & - & $0.17 \pm 0.17$ & - & - & $0.25 \pm 0.15$ & $0.00 \pm 0.00$ & $2.70 \pm 0.70$ & - & $11.30 \pm 0.80$ & 2.40 \\
\hline Santana & $0.00 \pm 0.00$ & - & $0.13 \pm 0.00$ & - & - & $0.15 \pm 0.15$ & - & $0.35 \pm 0.05$ & - & $12.43 \pm 5.18$ & 2.61 \\
\hline DH Mansholt & $0.47 \pm 0.47$ & - & $0.37 \pm 0.17$ & - & $0.80 \pm 0.30$ & $0.00 \pm 0.00$ & $0.55 \pm 0.35$ & $1.60 \pm 0.40$ & - & $20.55 \pm 3.75$ & 3.48 \\
\hline Oase & & - & $0.20 \pm 0.13$ & - & - & $0.15 \pm 0.15$ & $1.45 \pm 1.15$ & $1.70 \pm 0.40$ & - & $10.45 \pm 1.25$ & 2.79 \\
\hline DH Samourai & & - & $0.46 \pm 0.46$ & - & - & $0.00 \pm 0.00$ & - & $5.90 \pm 1.60$ & - & $18.95 \pm 4.05$ & 6.33 \\
\hline Mean value & 0.38 & - & 0.47 & - & 1.65 & 0.28 & 0.99 & 2.94 & - & 12.55 & \\
\hline
\end{tabular}


Appendix

Semi-field field experiment:

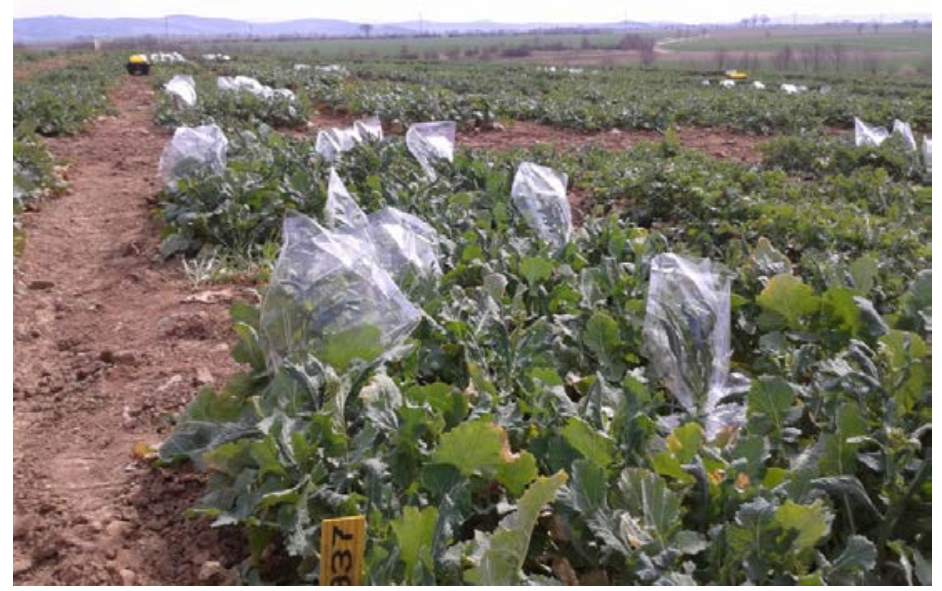

Fig. 2 Semi-field experiment at Einbeck 2012/2012. Four females of Ceutorhynchus napi were caged with a perforated plastic bag on the main stem of five Brassica napus genotypes

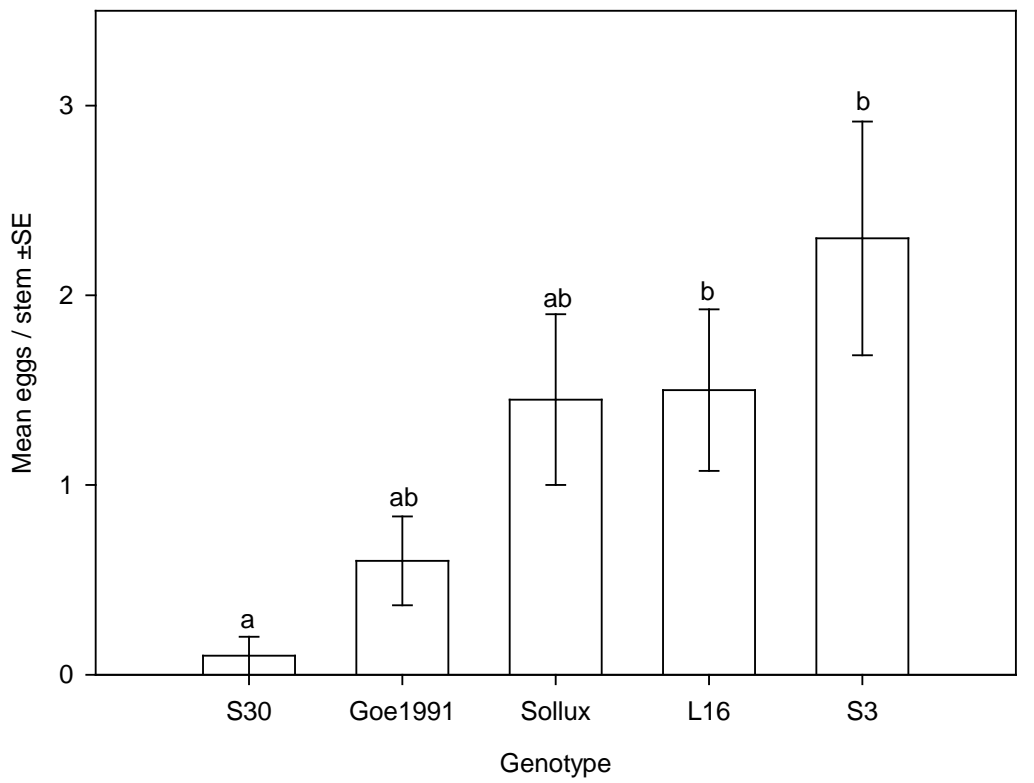

Fig. 3 Number of eggs deposited by four females of Ceutorhynchus napi into main stems of five Brassica napus genotypes during three days in the semi-field experiment 2012/2013 at Einbeck. Mean values $( \pm$ SE) of twenty replicates, $(H(4, N=100)=17.502, P=0.002)$, Kruskal-Wallis Test, $P \leq 0.05$ 
Appendix

Table 5 Infestation of pods of 30 Brassica napus genotypes by brassica pod midge (Dasineura brassicae Winn.). Percentage of split pods related to the total number of pods of three upper side shoots of 30 plants. Genotypes were grown in field experiments at different locations in 2010/2011, 2011/2012 and 2012/2013. Values are means five plants and two to four replicates. KW-ANOVA, $P \leq 0.05$; Marienstein June $6^{\text {th }} 2011(H(20, N=42)=29.200, P=0.084)$, Göttingen-Weende May $28^{\text {th }} 2012(H(29, N=60)=35.752, P=$ $0.181)$, Peine June $21^{\text {st }} 2013(H(6, N=14)=2.286, P=0.892)$

\begin{tabular}{|c|c|c|c|c|}
\hline \multirow[b]{2}{*}{ Genotype } & \multirow[b]{2}{*}{ Marienstein 2011} & \multicolumn{3}{|l|}{$\%$} \\
\hline & & Weende 2012 & Peine 2013 & $\begin{array}{l}\text { Mean } \\
\text { value }\end{array}$ \\
\hline H327 & 25 & 57 & - & 41 \\
\hline S3 & 90 & 48 & 11 & 50 \\
\hline L16 & 76 & 57 & - & 67 \\
\hline L122 & 69 & - & - & 69 \\
\hline G53 & 73 & 40 & - & 57 \\
\hline S30 & 65 & 47 & - & 56 \\
\hline Sollux & 71 & 37 & - & 54 \\
\hline Campala & 39 & 39 & - & 39 \\
\hline H10 & 38 & - & 11 & 25 \\
\hline Express617 & 47 & 33 & - & 40 \\
\hline Н30 & 53 & - & - & 53 \\
\hline Mendel & 62 & 49 & - & 56 \\
\hline Visby & 70 & 54 & - & 62 \\
\hline H65 & 71 & - & - & 71 \\
\hline H149 & 68 & - & - & 68 \\
\hline Grizzly & 64 & 37 & - & 51 \\
\hline DH Mansholt & 30 & 36 & 10 & 25 \\
\hline Olimpiade & 91 & - & 11 & 51 \\
\hline Goe1991 & 77 & 52 & - & 65 \\
\hline Liropa & 80 & 38 & - & 59 \\
\hline S14 & 60 & 44 & - & 52 \\
\hline Oase & - & 39 & - & 39 \\
\hline H113 & - & - & 8 & 8 \\
\hline R140 & - & - & 10 & 10 \\
\hline R53 & - & - & 9 & 9 \\
\hline Abukuma natane & - & - & - & - \\
\hline DH Samourai & - & - & - & - \\
\hline Santana & - & - & - & - \\
\hline Gaoyou & - & - & - & - \\
\hline H231 & - & - & - & - \\
\hline Mean value & 63 & 44 & 10 & \\
\hline
\end{tabular}




\section{Acknowledgements}

I sincerely thank Prof. Dr. Stefan Vidal for giving me the opportunity to work in his group, answering my questions, giving me suggestions and reviewing this thesis.

Many thanks go to Prof. Dr. Heiko C. Becker for co-reviewing this thesis, the good collaboration with the Institute of Plant Breeding and for providing seeds of rare genotypes.

I am deeply grateful to Dr. Bernd Ulber for supporting me in my experiments, answering and discussing my questions so many times and for his very constructive critique.

Very special thanks go to Dr. Ines Vollhardt, for helping me in the fields, analyzing so many plant samples and for answering my questions.

I would also like to thank Haiko Brandes for analyzing the glucosinolates and helping to care the field experiments. Thank you, Birgit Olberg and Uwe Ammermann for also helping to analyze the glucosinolates. I am thankful to Hubertus Reintke and Gerald Miotke, the technical staff in the fields.

Special thanks for the support in the greenhouse and laboratory go to Dorothea Mennerich.

I thank Prof. Dr. Rolf Rauber for giving me the opportunity to analyze the plant elements of my samples in his institute and Gabriele Kolle for helping me to analyze the samples.

I am also grateful to Dr. Christoph Scherber for helping me with statistical questions and providing the model for analyzing glucosinolates. I also like to thank Maxime Hervé for providing the multivariate statistic macro and answering my statistical questions.

Further, I thank Eugen Hodyl and Maik Knobel for their technical support in the greenhouse.

Special thanks go to my colleagues and helpful students for their support in the field, statistical assistance and for the enjoyable working atmosphere: Dr. Katharina Lohaus, Dr. Mario Schuhmann, Dr. Alexander Döring, Dr. Lana Dobrindt, Antje Reinhardt, Helge Stahlmann, Leilei Zhang, Henrike Hennies, Sebastian Miersch, Li Shia Teh, Jan Öhlschläger, Tilman Lüddeke, all research assistants and all other working group members who shared with me this exploratory time in Göttingen.

I am grateful to Edward Hubbell for the linguistic improvements of the manuscripts.

I am deeply grateful to my husband Christoph Schäfer, the most reliable and endearing person I have met in my life. He helped me in every situation during my study and in my life. During my life I always had support from my family, parents-in-law and my friends. 


\section{Curriculum vitae}

Surname, first name: $\quad$ Schaefer-Koesterke, Heike Lena

Date of birth: $\quad$ April $29^{\text {th }}$, 1984

Civil status: married

Citizenship: German

Education

Since 03/2011

10/2003 - 09/2010

$09 / 2000$ - 09/2003

09/1994 - 09/2000

Work experience

08/2009 - 09/2009

05/2009 - 07/2009

05/2006 - 06/2006

Conference

06/11/ 2013

09/10/2013

20/04/2013

27/02/2013

07/11/2012

Agriculture and Agri-Food Canada, Pacific Agri-Food Res. Cen. Weleda Naturals Company in Schwaebisch Gmuend

Federal Institute of Biology (today JKI), in Kleinmachnow

$\mathrm{PhD}$ student at the Georg-August University in Goettingen;

Department of Crop Science, Division of Agricultural

Entomology

Study of Agricultural Biology at the University of Hohenheim; Final exam: Dipl. Agr. Biol. (equivalent MSc)

High school (Johann-Philipp-Palm Wirtschaftsgymnasium, Schorndorf), with „Allgemeine Hochschulreife“ as final exam

Middle school (Hohberg Realschule, Pluederhausen), with „Mittlere Reife“ as final exam

GFP (Community for promoting of Private Plant Breeding) in Bonn; oral presentation

IOBC (International Organization of Biological and Integrated Control) in Luxembourg; oral presentation

DgaaE (German Society for General and Applied Entomology) in Goettingen; poster presentation

DPG (German Society of Phytomedicine) in Braunschweig, oral presentation

GFP, in Bonn; oral presentation

Membership

Since 11/2011

DPG (German Society of Phytomedicine) 


\section{E r k l äru n gen}

1. Hiermit erkläre ich, dass diese Arbeit weder in gleicher noch in ähnlicher Form bereits anderen Prüfungsbehörden vorgelegen hat.

Weiter erkläre ich, dass ich mich an keiner anderen Hochschule um einen Doktorgrad beworben habe.

2. Hiermit erkläre ich eidesstattlich, dass diese Dissertation selbständig und ohne unerlaubte Hilfe angefertigt wurde. 